\title{
Preliminary release of scientific reports on the acidic drainage in the Animas River watershed, San Juan County, Colorado
}

\author{
Compiled by Stanley E. Church ${ }^{1}$
}

Open-File Report 00-034

This report is preliminary and has not been reviewed for conformity with U.S. Geological Survey (USGS) editorial standards or with the North American Stratigraphic Code. Any use of trade, firm, or product names is for descriptive purposes only and does not imply endorsement by the U.S. Government.

U.S. DEPARTMENT OF THE INTERIOR

U.S. GEOLOGICAL SURVEY

${ }^{1}$ Denver Federal Center, Denver, Colorado 80225 


\section{Table of Contents}

Chapter 1. Geologic control on acidic and metal-rich waters in the southeast

Red Mountains area, near Silverton, Colo., by D. J. Bove, M.A. Mast, W.G. Wright, P.L. Verplank, G.P. Meeker, and D.B. Yager.

Chapter 2. Pre-mining bed sediment geochemical baseline in the Animas River watershed, southwestern Colo., by S.E. Church, D.L., Fey, and Robert Blair.

Chapter 3. Distribution of acid-generating and acid-buffering minerals in the Animas

River watershed as determined by AVIRIS, by J.B. Dalton, T.V.V. King,

D.J. Bove, R.F. Kokaly, R.N. Clark, J.S. Vance, and G.A. Swayze.

Chapter 4. Comparison of two leach procedures applied to metal-mining related wastes in Colorado and Montana and a relative ranking method for mine wastes, by D.L. Fey, G.A Desborough, and S.E. Church.

Chapter 5. Quantifying effects of metal loading from mine drainage, by B.A. Kimball, K.E. Bencalla, and R.L. Runkle.

Chapter 6. An investigation of the partitioning of metals in mine wastes using sequential extractions, by R.W. Leinz, S.J. Sutley, G.A. Desborough, and P.H. Briggs

Chapter 7. Natural sources of metals to surface waters in the upper Animas River watershed by M.A. Mast, P.L. VerPlank, D.B. Yager, W.G. Wright, and D.J. Bove

Chapter 8. The role of weathering in trace metal redistributions in the Mayday Mine Dump near Silverton, Colo., by M.R. Stanton.

Chapter 9. Utilization of airborne magnetic, electromagnetic, and radiometric data in abandoned mine land investigations, by B.D. Smith, A.E. McCafferty, and R.R. McDougal

Chapter 10. Chemical-constituent loads during thunderstorm runoff in a high-altitude alpine stream affected by acid drainage, by Laurie Wirt, K.J. Leib, M.A. Mast, and J.B. Evans

Chapter 11. Natural versus mining-related water quality degradation to tributaries draining Mount Moly, Silverton, Colo., by D.B. Yager, P.L. Verplank, D.J. Bove, W.G. Wright, and P.L. Hageman.

Chapter 12. Multidimensional spatial modeling of the May Day Mine waste pile, Silverton, Colo., by D.B. Yager and M.R. Stanton 


\section{Disclaimer}

The following papers have been accepted for publication in the Proceedings of the International Conference on Acid-Rock Drainage to be held in Denver, May 22-25, 2000. The purpose of this open-file report is to make these data available to the public, particularly the residents of Silverton, Colo. in the Animas River watershed, so that these data can be used in preparation for the upcoming hearing before the Colorado Water Quality Commission on water quality standards in the Animas River watershed. This report will be superceded by publication of the conference proceedings and will be withdrawn on June 1,2000. All formal reference to these reports should be made in the proceedings of the ICARD conference. 


\title{
Geologic Control on Acidic and Metal-Rich Waters in the Southeast Red Mountains Area, Near Silverton, Colorado
}

\author{
Dana J. Bove,' M. Alisa Mast,' Winfield G. Wright,, ${ }^{2}$ Philip L, Verplanck,' Greg P. Meeker,' \\ and Douglas B. Yager
}

\begin{abstract}
Areally extensive acid sulfate-altered and mineralized rock in the southeast Red Mountains area is noted for its association with naturally occurring and mine-related acidic and metal-rich waters. Integrated geologic and aqueous geochemical studies demonstrate that the degree of metal mobilization and acid production in natural waters correlates well with the type of hydrothermally altered rock and structural features in which these water interact. Quartz-sericite-pyrite, quartz-alunite, and argillic alteration assemblages are associated with some of the most naturally acidic, high-metal waters in the study area; calcite-bearing propylitic rocks are related to the most pristine waters and buffer sulfate-rich, acidic waters produced by pyrite oxidation. Trace metals in natural waters are mostly derived from enargite, zinc-rich tetrahedrite and sphalerite. Pyrite oxidation contributes very little with respect to base-metals in these natural waters.
\end{abstract}

\section{INTRODUCTION}

The Red Mountain Pass area, near Silverton, Colorado, has long been known for its spectacular tan and red, bleached landscape and the production of some of the richest ores mined in Colorado. The red and bleached bedrock, caused by the oxidation of large quantities of finely-disseminated pyrite, together with the arsenic, copper, and silver-rich mines, produce the acidic and metal-rich surface waters characteristic of the area. Early geologic studies provide vivid descriptions of the corrosive nature of the natural and mine-related waters. In a geologic report of the area, T.E Schwarz (1883) remarks that "iron springs abound, and in depth, the minewater becomes all that is objectionable, readily disposing of a 1/4-inch thick wrought iron column-pipe in four weeks time; good water is not to be found." The presence of iron-oxide cemented conglomerate above present stream levels indicates that naturally metal-rich drainage has been active in this area for thousands if not millions of years.

The southeast Red Mountains study area (Fig. 1), which comprises Prospect Gulch, Georgia Gulch and the high slopes of Red Mountain \#3 (Fig. 2), encompasses the margins of an extensive $23 \mathrm{Ma}$ acid-sulfate hydrothermal system with related Ag-Cu-Au breccia pipe and fault-hosted mineralization (Bove et al., 1999). Recent studies indicate that both natural and mine-related waters within the study area are major contributors of iron, aluminum, zinc, and other trace metals to Cement Creek, a major tributary of the upper Animas River (Bove et al., 1998; Wirt et aI., 1999).

Integrated geologic and aqueous geochemical studies in the southeast Red Mountains study area are part of an ongoing project to provide technical suppor towards reclaiming abandoned mine sites on Federally owned land (Nimick and von Guerard, 1998). The objectives of the current study are to (1) characterize the geology and mineralogy of the study area, (2) understand the relationships between specific hydrothermal alteration assemblages, other structural and mineralogic features, and local water chemistry, (3) quantify water-rock interactions by mass-balance modeling using detailed geologic and mineralogic data, and (4) characterize natural and mine-related metal contributions to the local surface waters. To accomplish these goals, we carefully mapped and studied the bedrock geology, hydrothermal alteration assemblages, and structural features in the study area, and sampled 47 streams, springs and mine waters mostly during summer base-flow conditions (1997-1998).

'U.S. Geological Survey, Federal Center, Denver, CO 80225-0046

${ }^{2}$ U.S. Geological Survey, Durango, CO 81302 


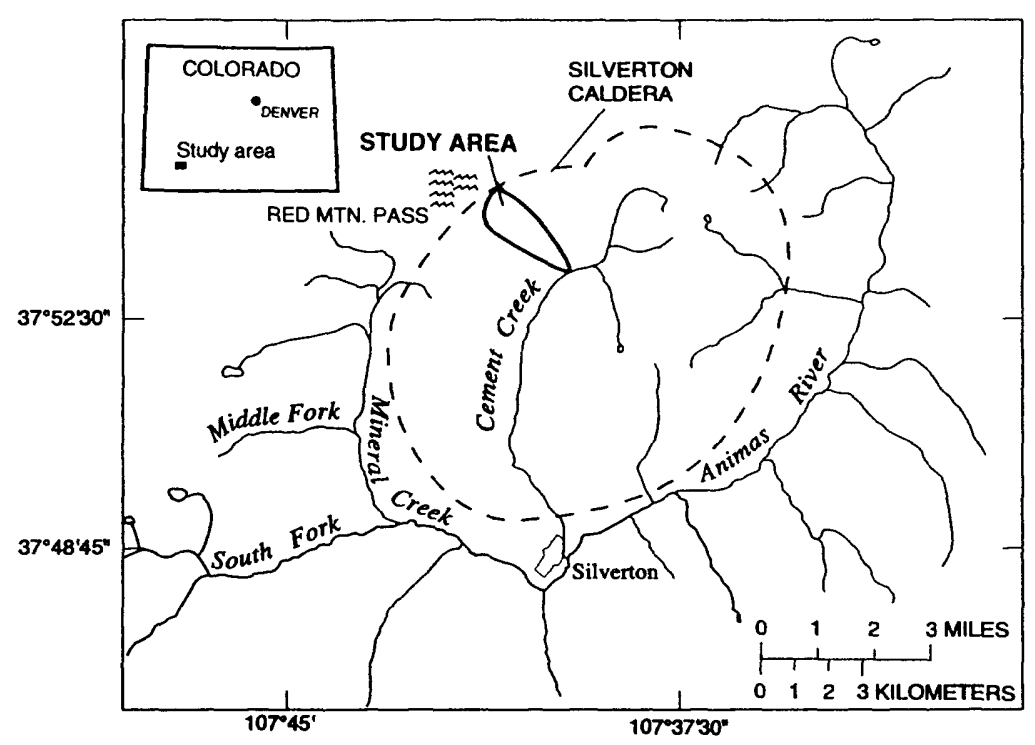

Figure 1 Generalized location map of the upper Animas River watershed showing the southeast Red Mountains study area.

\section{METHODS}

Field identification of mineral phases was confirmed by whole-rock X-ray diffraction (XRD). Clay minerals were studied by standard clay XRD techniques (Moore and Reynolds, 1989). Major and minor elemental analyses of minerals were obtained with a JEOL 8900 electron microprobe at the U.S. Geological Survey in Denver, Colorado; analytical precision and statistical errors are discussed in Wirt et al. (1999). During the course of this study, the locations of all adits, shafts, and significant prospects ${ }^{3}$ were plotted and their respective dumps were mapped. Based on this information and previous reports on mine workings in the area (King and Allsman, 1950; Burbank and Luedke, 1964), stream and spring waters were classified as either "natural" or "impacted" dependent on their geographic relationship to these workings. Water sample sites were classified as "natural" if no roads, adits, shafts or significant prospects were located upgradient of these sites. Conversely, stream or spring sites not meeting these criteria were termed "impacted." Water sampled from shafts or adits are referred to as "adit," "shaft" or simply "mine" waters. Details on the sampling and chemical analysis of water quality samples are described in Mast et al. (in this volume).

\section{REGIONAL GEOLOGY}

The Silverton caldera, which is nested within the larger San Juan caldera (28.2 Ma), formed in response to the eruption of the Crystal Lake Tuff 27.6 million years ago (Lipman et al., 1976; Bove et al., 1999). The Crystal Lake Tuff is mostly absent within the Silverton caldera undoubtedly due to erosion within this relatively shallow subsided depression. Instead, a thick sequence of finely porphyritic dacitic-andesitic lavas comprise the dominant rock units within the Silverton caldera (Burbank and Luedke, 1969); these lavas are referred to as the Burns Member of the Silverton Volcanic Series (Lipman et al., 1973; Burbank and Luedke, 1969). Rocks overlying the Burns Member vary considerably throughout the Silverton caldera and generally consist of interbedded volcaniclastic sediments, mudflow breccias, and interbedded lavas.

The Eureka graben, which is the downdropped, northeast-trending fault zone along the crest of the coalesced San Juan-Uncompahgre calderas, is an important host to mineralization that post-dates these calderas by about 5-15 Ma (Lipman et al., 1976). Hydrothermal activity temporally related to these calderas caused regional propylitization of the volcanic rocks (incipiently altered feldspars, chlorite \pm epidote \pm calcite) with associated weakly disseminated pyrite (Slack and Lipman, 1979). Although altered and mineralized rocks are in close spatial association with the San Juan, Uncompahgre, and Silverton calderas, alteration and

\footnotetext{
${ }^{3}$ Excavations exceeding $2-4 \mathrm{ft}$ in depth or width, or any size workings within stream drainage.
} 
嵌

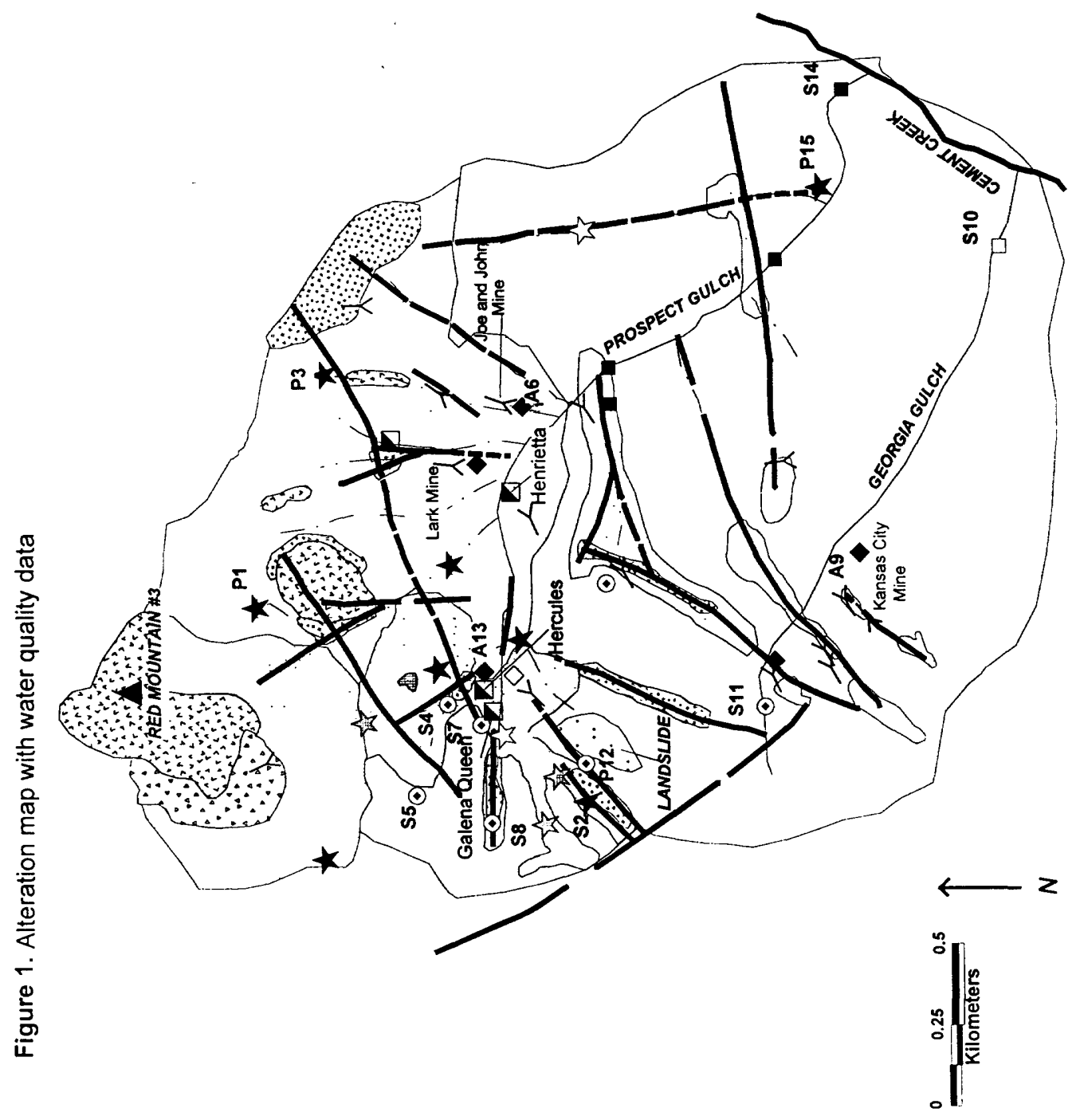


mineralization is rarely contemporaneous with caldera formation (Lipman et al., 1976; Slack and Lipman, 1979). The San Juan-Uncompahgre caldera cycle thus provided a favorable structural environment for later mineralization. Most mineralization and associated hydrothermal alteration in this area is temporally and genetically associated with three major episodes of high-level magmatism between about 10 to $26 \mathrm{Ma}$ (Bove et al., 1999).

\section{GEOLOGY AND MINERALIZATION OF THE STUDY AREA}

The southeast Red Mountains study area contains a massive acid-sulfate hydrothermal system that is host to associated $\mathrm{Ag}-\mathrm{Cu}$-Au breccia pipe and fault-hosted mineralization. Geologic relations and isotopic dating indicate that ore mineralization, hydrothermal brecciation, and pervasive hydrothermal alteration are intimately associated with episodic intrusion of dacite porphyry magma, all of which took place at about 23 Ma (Bove et al., 1999).

\section{Hydrothermal Alteration}

The northern slopes of Prospect Gulch (Fig. 2) represent the southernmost margins of an extensive $23 \mathrm{Ma}$ acid-sulfate hydrothermal system comprised of quartz-alunite \pm pyrophyllite-altered rocks and related quartzsericite-pyrite (QSP) alteration (Bove et al., 1998). Rocks affected by this ancient hydrothermal system make up the nearly $12 \mathrm{~km}^{2}$ of brilliant bleached to orange-red peaks in the vicinity of Red Mountain Pass, north of Silverton (Fig. 1). In contrast, rocks on the southern slopes of Prospect Gulch and in Georgia Gulch to the south (Fig. 2), represent a much weaker regional propylitic event ( $27-28 \mathrm{Ma})$ that was largely unaffected by the later $23 \mathrm{Ma}$ acid-sulfate altering fluids. Outcrops of dacite porphyry intrusion are spatially associated with the most intensely altered rock in the study area and are conspicuously absent in areas dominated by propylitic-altered rocks.

Quartz-sericite-pyrite assemblage. QSP-altered rock underlies a significant portion of the study area and extends upwards to the tops of many high ridges (Fig. 2). This assemblage is characterized by roughly 25-50\% fine-grained pervasive quartz, abundant well crystalline illite (sericite), and 10-20\% finely disseminated and fracture-filling pyrite. Mean thickness of fundamental illite particles by PVP intercalation (Eberl et al., 1998) - used as an indicator of alteration intensity and zonation (Bove et al., unpub. data)ranges from 11 to 36 nanometers and averages 17 nanometers. Studies of a deep drill hole collared just north of the study area indicates that much of this QSP-altered rock may represent a transition upward from deeper potassium-rich alteration zones related to emplacement of high-level dacite porphyry magmas (Gilzean, 1984; Bove et al., 1990).

Sericite-pyrite assemblage. QSP-altered rock grades outward into a weaker and less silicified marginal zone of sericite-pyrite (SP) alteration (see Fig. 2). These rocks contain 5-15\% quartz and pyrite exceeds 10 volume percent of the rock. Oxidation of pyrite however, may be more prevalent in the weakly silicified, SP-altered rocks relative to their more silicified QSP counterparts. The less silicified rocks are more easily weathered and thus more susceptible to pyrite oxidation. In contrast to the QSP assemblage, illite within the marginal SP zone is poorly crystalline, and has a mean fundamental particle size of 4 to 8 nanometers. Similar zoned physical and structural changes in illites, such as those within the QSP and SP assemblages, have also been observed in studies of deep drill core from similarly mineralized and altered rocks near Lake City, Colorado (Bove and Eberl, unpub. data). Studies from the Lake City area show a rapid increase in fundamental illite particle size that correlates with an increase in base metal concentration and proximity to an underlying dacite porphyry intrusive body (Bove et al., 1990). The increase in mean illite particle size within the study area also corresponds with increasing alteration intensity and proximity to intrusions; however, zonation in associated metal content, although expected, is only conjectural.

Propylitic assemblage. Propylitic alteration generally reflects a regional event that preceded 23 Ma acidsulfate alteration in the Red Mountains area by at least 3 million years (Lipman et al., 1976; Bove et al., 1999). Mass balance studies indicate that primary rock-forming elements were mostly conserved during propylitic alteration (Fisher and Leedy, 1973; Bove et al., 1990); however, sulfur was added to most of these rocks in the form of minor finely disseminated pyrite. Primary rock-forming minerals were variably replaced by fine mixtures of epidote, chlorite, calcite, and illite. Abundances of any one of these four minerals range from 0 to 30 volume percent of the rock, whereas collective totals span from $<5$ to 40 volume percent. In general, plagioclase crystals were mostly albitized and incipiently to moderately altered to mixtures of epidote, calcite, 
chlorite, and illite. Most iron and magnesium-bearing minerals such as biotite, hornblende, and diopsidic pyroxene show near complete replacement by chlorite, epidote, illite, and fine-grained iron oxides.

Although most propylitic alteration formed during a regional hydrothermal event ( $>26 \mathrm{Ma}$ ago), some localized propylitic alteration formed at $23 \mathrm{Ma}$ peripheral to mineralized and altered faults and fractures. Although this younger assemblage grossly resembles the regional propylitic assemblage, it is distinguished largely by the presence of relatively coarse-grained pyrite along fractures and by quartz, chlorite and magnetite within veinlets.

Acid-sulfate alteration. Detailed field mapping and combined X-ray diffraction studies indicate that fault and breccia-controlled zones of acid-sulfate alteration are generally superimposed on broad intervening expanses of QSP-altered rock and upon QSP/SP-altered fault zones in propylitically altered rock (Fig. 2). These composite acid-sulfate alteration zones typically transition outward from quartz-alunite into pyrophyllite, dickite, and (or) propylitic-altered rock; sericite is generally not a component of this zonation. Mineralogical data from three exploratory drillholes collared along a broad north-south structural zone above the Lark Mine (Fig. 2), demonstrate that acid-sulfate alteration zones have roots extending at least $1,000 \mathrm{ft}$ beneath the ground surface. Rock from these drill core average $120 \mathrm{ppm} \mathrm{Cu}, 334 \mathrm{ppm} \mathrm{Pb}$, and $31 \mathrm{ppm} \mathrm{Zn}$. Fine pyrite, which is disseminated and present along networks of tiny fractures, ranges from 20-30 weight percent within these samples.

A moderately dipping tabular zone of finely silicified and hydrothermally brecciated rock is present in the vicinity of Red Mountain \#3 (Fig. 2). Surficial mapping and unpublished drill log data (Amoco Minerals) indicate that this $200-\mathrm{ft}$ thick breccia mass abruptly transitions downward and outward into strongly argillized rocks composed of dickite, minor to moderate quartz, and abundant finely disseminated pyrite. The upper breccia mass is composed of banded and intensely brecciated jasperoidal quartz; the lower half contains abundant vugs filled with clay, jarosite, iron-oxides, and rare native sulfur. Zones of quartz-alunite-altered rock are spatially associated with the silicified breccia, and these in turn also grade outward into argillized rock. Disseminated pyrite (10-25\%), enargite, and lesser covellite and galena are present throughout the entire silicified breccia. However, sulfides are mostly oxidized within the uppermost $220-280 \mathrm{ft}$ of this entire mineralized zone. Although gold and silver are anomalously concentrated within the silicified breccia (averaging $0.03 \mathrm{oz} /$ ton $\mathrm{Au}, 0.6 \mathrm{oz} /$ ton $\mathrm{Ag}$ ), these metals are lacking in argillized rocks beneath and bounding the breccia mass (Matlock and Hollister, 1990).

\section{Soils and Precipitates}

Soils formed from the decomposition of fresh to propylitic altered rock contain smectite and illite, with minor amounts of kaolinite and chlorite. Clays within soils formed from intensely altered rocks (QSP, SP) however, consist of illite, and minor amounts of chlorite and kaolinite. The absence of kaolinite in any major alteration assemblages suggests that this clay formed by neoformation. Whereas, the compositional similarities of illite and chlorite within soils and hydrothermally altered protolith strongly suggest that these soil minerals were inherited. Lack of detailed clay studies on propylitic altered rocks, however, make it difficult to assess the origin of smectite within these associated soils.

Precipitates within mildly to moderately acidic stream channels consist mostly of X-ray amorphous iron hydroxides with minor amounts of goethite. An iron precipitate mound at an acidic spring near the mouth of Prospect Gulch (site P15; Fig. 2) is comprised of major amounts of X-ray amorphous iron hydroxide, goethite, and jarosite. An X-ray amorphous aluminum hydroxide precipitate was found in the stream channel just below site P12 (Fig. 2).

\section{Mining and Ore-Related Minerals}

Ore minerals present within the major mines in the southeast Red Mountains study area formed mostly at 23 $\mathrm{Ma}$ and are localized along large ( $>150 \mathrm{ft}$ wide), mineralized fault structures and spatially associated hydrothermal breccia masses (Fig. 2)(Bove et al., 1999). These ores are mineralogically similar to the contemporaneous but more famous 23 Ma mineralized breccia deposits (i.e., National Belle, Yankee Boy, and Guston mines; Ransome, 1901; Fisher and Leedy, 1973; Nash, 1975) in the adjacent Red Mountain Pass area. Although hydrothermal breccias are common in the study area (Fisher and Leedy, 1973; Nash, 1975; Bove et al.,1998), classic mineralized "breccia bodies," such as those observed in the Red Mountain Pass area, do not crop out at the surface.

Representative samples obtained from waste and ore dumps from some of the larger mines in Prospect Gulch have been studied by petrographic microscope, X-ray diffraction, and electron microbeam studies (Wirt 
et al., 1999, Table 1, p. 21). These studies show the major ore minerals to consist of pyrite, sphalerite, galena, enargite, and arsenic- and zinc-rich tetrahedrite, in decreasing order of abundance. Gangue and related minerals include alunite, pyrophyllite, quartz, and illite, with minor amounts of barite, diaspore, anglesite, and zunyite. Genesis of the acid-sulfate/breccia ores in the study area and in the adjacent Red Mountain Pass area has been clarified recently by geologic and stable isotope studies (Bove and Rye, unpub. data), and is very similar in nature to the acid-sulfate hydrothermal systems and related ore deposits in the Summitville and Lake City areas of Colorado (Bove et al., 1990; Gray and Coolbaugh, 1994; Bove et al., 1999).

\section{WATER CHEMISTRY}

Natural Sources of Acidity and Heavy Metals to Surface Waters

Geochemical data from a subset of stream, spring, and mine effluent waters sampled within the study area are shown in Table 1, sample locations are shown on Figure 2. Plots depicting those waters that interacted with near end-member alteration assemblages are shown on Figure 3. From these data it is apparent that individual alteration assemblages produce relatively distinctive aqueous geochemical signatures. As shown on Figure 2, the large expanse of QSP-altered rock on the north side of Prospect Gulch and argilic and quartz-alunite altered rock south of Red Mountain \#3 are associated with some of the most naturally acidic waters in the study area (median pH 3.1 and 3.3), with mean conductivity of 654 and $820 \mu \mathrm{S} / \mathrm{cm}$, and base metal sum ( $\mathrm{Zn}$ $+\mathrm{Cu}+\mathrm{Cd}+\mathrm{Ni}+\mathrm{Co}+\mathrm{Pb}$ ) of 281 and $751 \mu \mathrm{g} / \mathrm{L}$, respectively. In contrast, waters draining SP and mixed SP and propylitic-altered rock on the margins of the hydrothermal system are less acidic and lower in metals with median $\mathrm{pH}$ values of 3.6 and 6.1 , mean specific conductance of 338 and $142 \mu \mathrm{S} / \mathrm{cm}$, and mean sum of base metals of 252 and 76, respectively. Waters influenced by propylitic-altered rocks, which are largely south of the axis of Prospect Gulch (Fig. 2), generally have the lowest metal concentrations in the study area. These waters have a median $\mathrm{pH}$ value of 5.9 , mean alkalinity of $14 \mu \mathrm{g} / \mathrm{L}$, and mean conductivity and base metal sum of $58 \mu \mathrm{S} / \mathrm{cm}$ and $77 \mu \mathrm{g} / \mathrm{L}$, respectively.

In addition to mineralogical differences in bedrock geology, structural components such as fractures, bedding planes, and surficial deposits such as landslides and talus slopes, also may play a key role in the generation and occurrence of low pH and metal-rich surface waters. For example, spring P15, which discharges at the base of a NNW-trending fracture zone (Fig. 2, Table 1), has the lowest pH and highest metal concentrations of all unimpacted surface waters collected in the study area. Although the fracture zone is hosted in propylitic-altered rocks, the spring water appears to reflect the influence of QSP and acid-sulfate

Table 1 Water quality data from a subset ${ }^{1}$ of springs, streams, and mines in the study area.

[Site locations (No.) are shown on Figure 2. Alt.= dominant alteration type. S, P, or A, preceding No. is stream, spring, or adit or shaft. $\mathrm{SC}=$ specific conductance. Metals is sum of $\mathrm{Cu}, \mathrm{Co}, \mathrm{Cd}, \mathrm{Ni}, \mathrm{Zn}, \mathrm{Pb}$.]

\begin{tabular}{|c|c|c|c|c|c|c|c|c|c|c|c|c|c|c|}
\hline No. & Alt. & $\mathrm{pH}$ & SC & $\mathrm{Mg}$ & $\mathrm{Ca}$ & $\mathrm{Na}$ & $\mathrm{Si}$ & $\overline{\mathrm{SC}}$ & $\overline{\mathrm{Al}}$ & $\mathrm{Fe}$ & $\mathrm{Mn}$ & $\mathrm{Zn}$ & $\mathrm{Cu}$ & $\overline{\text { Metals }}$ \\
\hline P1 & QSP & 3.25 & 654 & 10.1 & 35.1 & 0.32 & 15.6 & 238 & 14,190 & 5,212 & 1,473 & 156 & 45 & 253 \\
\hline S2 & SP & 2.98 & 608 & 2.6 & 16.9 & 0.13 & 7.7 & 145 & 1,710 & 8,189 & 1,105 & 92 & 34 & 177 \\
\hline P3 & QSP & 2.75 & 940 & 6.3 & 4.3 & 0.22 & 28.3 & 327 & 8,835 & 41,924 & 582 & 132 & 188 & 394 \\
\hline S4 & SP/PRO & .16 & 103 & 2.0 & 13.6 & 0.76 & 3.6 & 33 & 122 & 421 & 66 & $<3$ & 5 & $<80$ \\
\hline S5 & PROP & 6.05 & 57 & 1.2 & 7.4 & 0.37 & 1.9 & 16 & $<1$ & 30 & $<1$ & $<3$ & 4 & $<80$ \\
\hline A6 & MINE & 2.79 & 1087 & 1.9 & 2.0 & 0.29 & 62.2 & 367 & 12,610 &, 300 & 244 & 960 & 638 & 3,610 \\
\hline S7 & PROP/SP & 6.60 & 228 & 5.1 & 33.0 & 1.77 & 4.5 & 61 & $<1$ & 67 & 81 & $<3$ & 6 & $<80$ \\
\hline S8 & SP & 15 & 118 & 1.5 & 11.1 & 0.49 & 6.3 & 45 & 1,580 & 30 & 245 & $<3$ & 10 & 82 \\
\hline A9 & MINE & 3.30 & 775 & 6.7 & 77.9 & 0.81 & 11.4 & 338 & 3,114 & 6,599 & 10,800 & 3,951 & 619 & 4,780 \\
\hline S10 & $\mathrm{MIX}^{2}$ & 5.86 & 205 & 3.9 & 27.0 & 0.95 & 7.6 & 95 & 43 & 55 & 323 & 424 & 10 & 489 \\
\hline S11 & PROP ${ }^{3}$ & 6.54 & 316 & 8.3 & 44.2 & 1.06 & 5.7 & 143 & 133 & 30 & 559 & 178 & 4 & 234 \\
\hline $\mathrm{P} 12$ & PROP ${ }^{3}$ & 6.40 & 685 & 8.4 & 110.8 & 1.87 & 5.7 & 320 & $<1$ & 48 & $<1$ & $<3$ & 4 & 76 \\
\hline A 13 & MINE & 2.35 & 1780 & 0.8 & 3.1 & 0.35 & 15.3 & 691 & 5,870 & 17,645 & 205 & 52,370 & 3,924 & 56,680 \\
\hline S14 & MIX $^{2}$ & 3.41 & 234 & 1.5 & 7.0 & 0.40 & 9.5 & 51 & 1,764 & 5,585 & 155 & 1,052 & 136 & 1,376 \\
\hline P15 & $\operatorname{MIX}^{2}$ & 3.13 & 860 & 8.6 & 32.1 & 1.12 & 58.2 & 351 & 20,695 & 55,146 & 758 & 1,072 & 4 & 1,137 \\
\hline
\end{tabular}

${ }^{\mathrm{l}}$ Some water analyses cited in this report are yet unpublished and do not appear in this table.

${ }^{2}$ Mixed influence from several alteration assemblages.

${ }^{3}$ Mixed SP and PROP with important structural component. 
rocks along the upper slopes of Prospect Gulch indicating that the fracture system may act as a conduit between these two areas. The tritium concentration in a sample from site P15 indicates the spring is fed by a mixture of recently recharged water and water that may be more than 50 years old. This older water component supports the idea that the fracture may control the flow of water over the relatively long distance between the headwater area and the discharge point of the spring. As shown on Figure 4, the chemistry of this spring water is strikingly similar to QSP-related waters. However, some of the minor differences in trace metals probably relate to interaction with $\mathrm{Cu}$-deficient mineralized vein material along the fracture conduit.

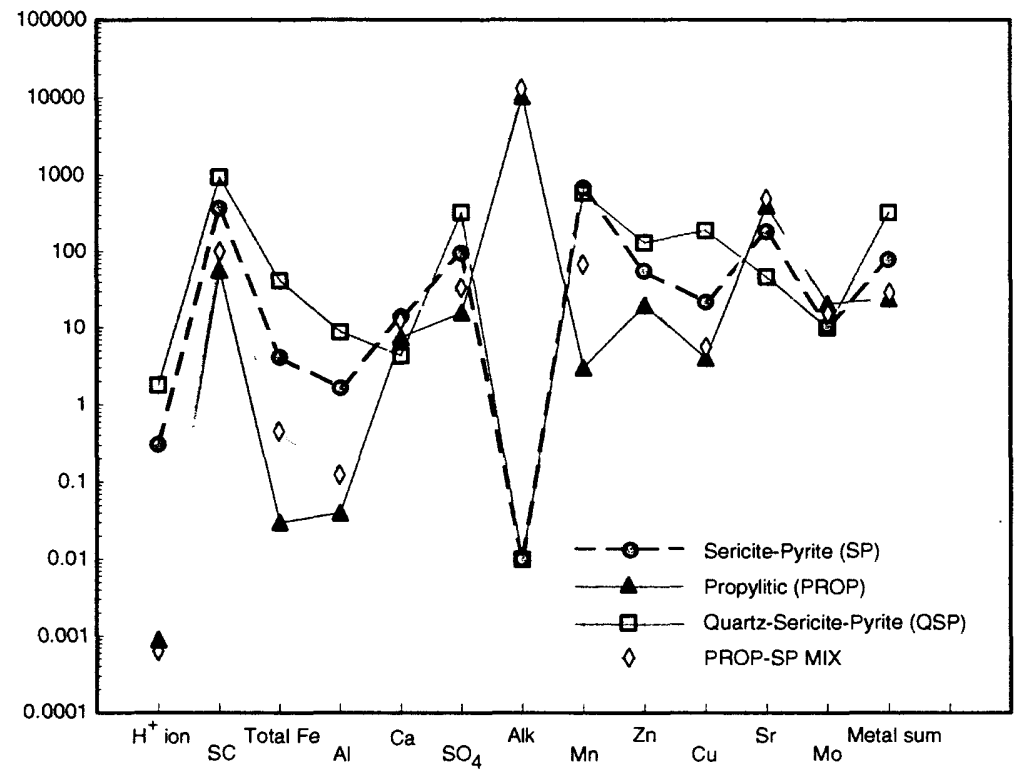

Figure 3 Constituents of natural waters related to various alteration assemblages. Individual plots average of several representative samples. $\mathrm{H}^{+}$ion multiplied by 1,000 .

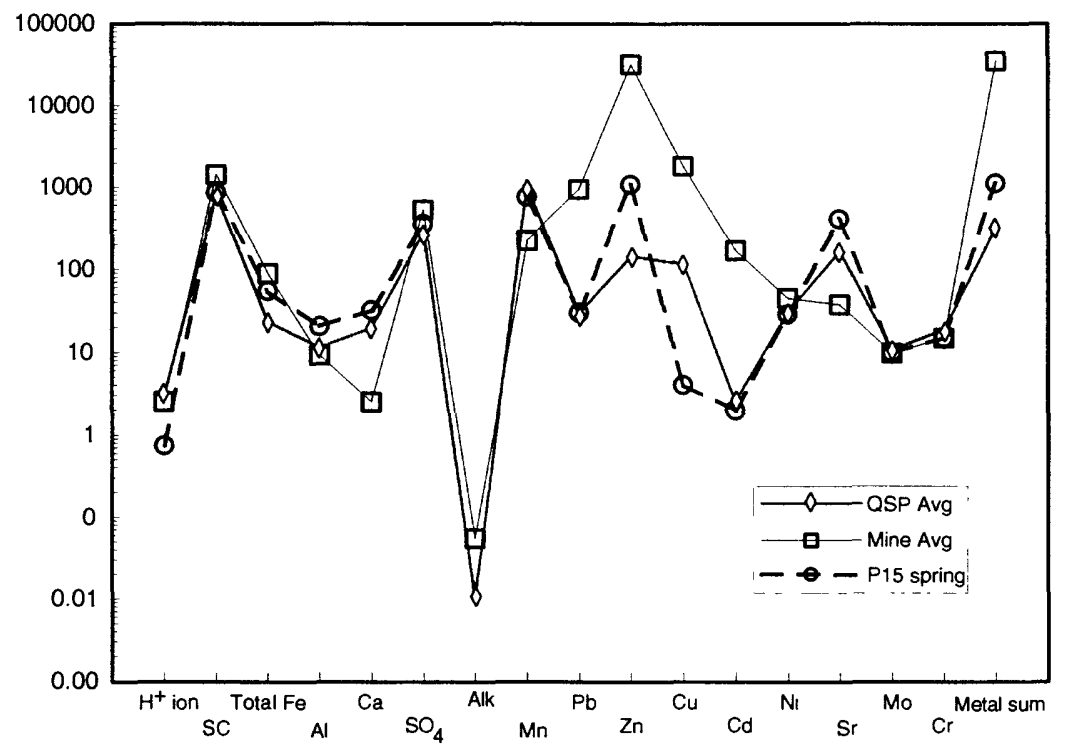

Figure 4 Constituents of average QSP water, average Prospect Gulch Mine water, and spring site P15. $\mathrm{H}^{+}$ion multiplied by 1,000 . 
Another example of the importance of structural control on water-rock interaction processes is illustrated on the southwestern slopes of Prospect Gulch. In this case, spring-fed waters discharging on both sides of a small landslide (Fig. 2) had pH values of about 6.5 with specific conductance values $>800 \mu \mathrm{S} / \mathrm{cm}$. Geochemical data from the western-most spring (P12) shows high concentrations of dissolved $\mathrm{SO}_{4}$ and $\mathrm{Ca}$ in conjunction with high alkalinity (Table 1). In contrast, stream water just upstream from site $\mathrm{P} 12$ had a pH of 6.5 and a specific conductance of $90 \mu \mathrm{S} / \mathrm{cm}$. The neutral and relatively dilute stream water undoubtedly reflects minimal water-rock interaction time as the water travels along the margins of the slide. In comparison, the highly concentrated spring waters likely indicate increased water-rock interaction time related to a bounding NE fracture zone (SP-altered rock) and water migration along the base of the landslide mass (propylitic/SP-altered rock).

\section{Mine Waters and Sources of Dissolved Metals}

Average mine waters from the Prospect Gulch area are enriched in $\mathrm{Pb}, \mathrm{Zn}, \mathrm{Cu}$, and $\mathrm{Cd}$ and depleted in $\mathrm{Ca}$ and Sr relative to the most "naturally" acidic/high-metal waters of this subbasin (Fig. 4). These differences can be explained by the concentration of the ore minerals pyrite, sphalerite, galena, enargite, and arsenic and zincrich tetrahedrite and the absence of calcite in the associated mines. Relative to other mine waters in the upper Animas River watershed (Nash, 1999, Mast et al., in this volume), mine discharge in Prospect Gulch is compositionally unique and relatively enriched in $\mathrm{Cu}, \mathrm{Pb}, \mathrm{Cd}, \mathrm{Cr}$, and $\mathrm{As}-$ a signature of the $23 \mathrm{Ma} \mathrm{Cu}$ and As-rich, acid-sulfate-related mineralization (Burbank et al., 1972). Mine waters associated with pervasive acid-sulfate altered rock also are notably depleted in $\mathrm{Sr}, \mathrm{Ca}$, and $\mathrm{Mn}$ relative to other mine waters outside the study area. In some instances, these apparent depletions may be directly correlated to the absence of ganguerelated minerals such as rhodonite $\left(\mathrm{MnSiO}_{3}\right)$, rhodochrosite $\left(\mathrm{MnCO}_{3}\right)$ and calcite; however they are also related to the scarcity of calcite and plagioclase $(\mathrm{Ca}, \mathrm{Sr})$, and chlorite and pyroxene $(\mathrm{Mn})$ that are associated with propylitic-dominant host rocks. This is illustrated by comparing mine drainage in propylitic-dominant host rock in adjacent Georgia Gulch to mine waters associated with acid-sulfate-altered host rock in northern Prospect Gulch. As shown in Table 1, effluent from the Kansas City mine in Georgia Gulch (S9) has more than ten times the dissolved constituents of $\mathrm{Mn}, \mathrm{Ca}$, and $\mathrm{Sr}$ as do mine waters from northern Prospect Gulch.

\section{Weathering Reactions from Inverse Geochemical Modeling}

Inverse geochemical modeling using the program NETPATH (Plummer et al., 1994) was performed on four diverse natural waters to identify geochemical water-rock reactions associated with some of the major mapped alteration assemblages; modeled waters represent springs or stream headwaters. Inverse modeling uses field data to interpret water analyses in terms of water-rock interactions along a known flow path. Modeling input includes water from two points along a flow path (initial and final product) and stoichiometric formulas of all minerals possibly interacting with the water along the path. Results of the modeling yield possible sets of water-rock interactions to explain the computed differences in concentration of various dissolved constituents in these two waters. Model results were evaluated on the basis of known mineralogical constraints (see sections on hydrothermal alteration, mineral precipitates, and soil mineralogy), NETPATH speciation calculations, and by a general knowledge of kinetic rates of mineral dissolution and precipitation. The compositions of most mineral phases likely to be dissolving and precipitating in these waters are given in Table 2. Starting water compositions were obtained from mean annual volume-weighted precipitation concentrations measured at a nearby monitoring station at Molas Pass (Mast et al., this volume). Results from the mass-balance analyses, which are shown in Table 3, varied considerably for each of the four waters, mostly reflecting differences in alteration intensity of the associated bedrock.

Propylitic alteration assemblage. Results from stream sample S5 represent water interaction with weakly fractured rock of typical propylitic composition. The model indicates that calcite comprises the largest dissolved mineral constituent and a very minor amount of pyrite were oxidized. Minor amounts of chlorite, albite, and illite were dissolved to account for other major cations. Epidote, although present within most propylitic-altered rocks was excluded as a potential reactant due to slow kinetics of dissolution in natural waters above pH 3.0 (G. Desborough, 1999, U.S. Geological Survey, unpub. data). The major secondary products indicated by the mass-balance solution are iron hydroxide and minor amounts of kaolinite and silica.

Modeling of spring sample P12 indicates the dissolution of very large amounts of both calcite and pyrite and relatively minor diopside, chlorite, and albite. As shown in Table 2, the preferred modeling results include secondary aluminum hydroxide (a precipitate found at the sample site) and silica, both of which were saturated in the NETPATH speciation calculations. This model demonstrates the important role of calcite- 
Table 2 Chemical data of select mineral phases (in weight percent) for mass balance study.

\begin{tabular}{lrrrrrr}
\hline Element & plag $^{1}$ & chlorite $^{1}$ & diopside $^{1}$ & illite $^{2}$ & epidote $^{\mathbf{l}}$ & pyrite $^{1}$ \\
\hline $\mathrm{NaO}_{2}$ & 11.20 & 0.01 & 0.37 & 0.10 & 0.01 & 0.00 \\
$\mathrm{MgO}$ & 0.00 & 18.46 & 15.26 & 1.38 & 0.00 & 0.00 \\
$\mathrm{Al}_{2} \mathrm{O}_{3}$ & 19.87 & 19.76 & 0.81 & 33.00 & 24.13 & 0.00 \\
$\mathrm{SiO}_{2}$ & 67.37 & 28.09 & 53.36 & 48.90 & 37.47 & 0.00 \\
$\mathrm{TiO}_{2}$ & 0.01 & 0.13 & 0.19 & 0.33 & 0.08 & 0.00 \\
$\mathrm{FeO}$ & 0.11 & 21.03 & 8.37 & $<0.08$ & 10.61 & 46.40 \\
$\mathrm{MnO}$ & 0.00 & 0.73 & 0.54 & 0.00 & 0.75 & 0.00 \\
$\mathrm{~K} \mathrm{O}$ & 0.19 & 0.09 & 0.00 & 9.32 & 0.00 & 0.00 \\
$\mathrm{CaO}$ & 0.81 & 0.08 & 21.87 & $<0.03$ & 21.97 & 0.00 \\
$\mathrm{BaO}$ & 0.01 & 0.00 & 0.02 & 0.00 & 0.00 & 0.00 \\
$\mathrm{~S}$ & 0.00 & 0.00 & 0.00 & 0.00 & 0.00 & 53.51 \\
$\mathrm{Cu}$ & 0.00 & 0.00 & 0.00 & 0.00 & 0.00 & 0.02 \\
$\mathrm{Zn}$ & 0.00 & 0.00 & 0.00 & 0.00 & 0.00 & 0.04 \\
$\mathrm{As}$ & 0.00 & 0.00 & 0.00 & 0.00 & 0.00 & 0.01 \\
$\mathrm{Co}$ & 0.00 & 0.00 & 0.00 & 0.00 & 0.00 & 0.06 \\
\hline
\end{tabular}

${ }^{1}$ Electron microprobe, this study.

2 (Eberl and others, 1987.)

Table 3 Results of mass balance modeling of natural waters draining the major alteration assemblages in study area. Positive values indicate dissolution and negative values indicate precipitaton in units of mmoles per liter of water. $\mathrm{nm}$ represents minerals not included in model.

\begin{tabular}{lcccc}
\hline $\begin{array}{c}\text { Mineral Phases } \\
\text { dissolved/precipitated }\end{array}$ & $\begin{array}{c}\mathbf{S 5}^{\mathbf{1}} \\
\text { PROP }\end{array}$ & $\begin{array}{c}\mathbf{P 1 2}^{\mathbf{2}} \\
\text { PROP-SP }\end{array}$ & $\begin{array}{c}\mathbf{S 8}^{\mathbf{3}} \\
\text { SP-PROP }\end{array}$ & $\begin{array}{c}\mathbf{P 3}^{\mathbf{4}} \\
\mathbf{Q S P}^{-}\end{array}$ \\
\hline Calcite & 0.178 & 2.600 & 0.229 & 0.096 \\
Pyrite & 0.080 & 1.664 & 0.231 & 1.700 \\
Chlorite & 0.030 & 0.121 & 0.013 & 0.159 \\
Illite & 0.004 & 0.000 & 0.011 & 0.015 \\
Albite & 0.004 & 0.020 & 0.005 & 0.001 \\
Diopside & 0.000 & 0.134 & 0.034 & 0.000 \\
$\mathrm{SiO}_{2}$ & 0.003 & -0.697 & -0.099 & -0.206 \\
$\mathrm{Goethite}_{\mathrm{Kaolinite}}^{-0.111}$ & -1.833 & -0.257 & -1.113 \\
$\mathrm{Al}(\mathrm{OH})_{3}$ & 0.030 & 0.000 & 0.000 & $\mathrm{~nm}$ \\
$\mathrm{CO}_{2}$ gas & $\mathrm{nm}$ & -0.170 & $\mathrm{~nm}$ & $\mathrm{~nm}$ \\
Pyrophyllite & -0.131 & -0.052 & -0.581 & -0.415 \\
$\mathrm{~nm}$ & $\mathrm{~nm}$ & $\mathrm{~nm}$ & -0.087 \\
\hline
\end{tabular}

${ }^{1}$ Propylitic alteration.

${ }^{2}$ Propylitic and sericite-pyrite alteration controlled by structural features.

${ }^{3}$ Sericite-pyrite and minor propylitic alteration.

${ }^{4}$ Quartz-sericite-pyrite and minor propylitic alteration.

bearing propylitic rocks in the buffering of acidity produced by pyrite. As discussed in a previous section, these neutral $\mathrm{pH}$ and high alkalinity waters (Table 1) probably derived their high sulfate concentrations from the faulted and SP-altered rock in which they originated (Fig. 2). Subsequently, the acidic starting waters then probably reacted with calcite-bearing propylitic rocks as they slowly migrated through a small landslide mass (Fig. 2).

Sericite-Pyrite alteration assemblage. Stream water interacting with SP-altered rock at site S8 is controlled by calcite and pyrite dissolution in roughly equal proportions. Although the amount of calcite dissolution only slightly increases relative to propylitic water sample S5, pyrite oxidation increases markedly, resulting in relatively lower $\mathrm{pH}$ and higher $\mathrm{SO}_{4}$ concentration in this water. Silicate mineral dissolution includes relatively small amounts of diopside and chlorite, followed by even less illite. Precipitation of iron-hydroxide and minor amounts of a silica phase were required to remove Fe and Si from solution. 
Quartz-Sericite-Pyrite assemblage. Modeling of spring water sample P3 indicates that large amounts of pyrite dissolution within QSP-altered rock ( $>5$ times that of SP model) was required to produce the associated highly acidic and iron-rich water. This model requires some pyrophyllite dissolution (from a nearby acid-sulfate alteration zone; Fig 2), which is reasonable in this low $\mathrm{pH}$ range. The dissolution of relatively minor amounts of calcite is probably related to the presence of small "islands" of propylitized rock that were left relatively unaffected by $23 \mathrm{Ma}$ QSP-altering fluids. Calcite and other Ca-rich minerals, although scarce, are still present within these islands. This model requires dissolution of pyrophyllite, chlorite, and very small amounts of illite to account for the $\mathrm{Al}$ and base cations within this water; albite dissolution is negligible. Iron hydroxide and silica were the only secondary mineral-forming phases.

Based on this model and the average $\mathrm{Zn}$ concentration within pyrite (Table 2), $0.00068 \mathrm{mmoles} / \mathrm{L}$ of $\mathrm{Zn}$ will be liberated during pyrite dissolution $(1.7 \mathrm{mmoles} / \mathrm{L})$. This accounts for only $44 \mu \mathrm{g} / \mathrm{L}$ of $\mathrm{Zn}$ within the resultant water, which is three times lower than the actual $\mathrm{Zn}$ concentration in sample P3 (132 $\mu \mathrm{g} / \mathrm{L}$; Table 1). Based on this calculation, it is reasonable to assume that only a minor portion of $\mathrm{Zn}$ and probably $\mathrm{Cu}$ within this sample is attributed to pyrite oxidation. Most likely, the concentration of combined $\mathrm{Zn}$ and $\mathrm{Cu}(320 \mu \mathrm{g} / \mathrm{L})$ within sample P3 is primarily related to the dissolution of sphalerite, enargite, and $\mathrm{Zn}$-rich tetrahedrite, which are common within rocks along this flow path. Although the results shown in Table 3 may not be the only defensible models to account for the measured water chemistry, they are consistent with the mineralogic and structural characteristics of drainage areas influencing these sites.

\section{CONCLUSIONS}

The sources of the dissolved constituents in natural water of the southeast Red Mountain Pass area can be described by geochemical weathering processes within a series of variably altered and mineralized rock. Most dissolved water constituents increase incrementally in conjunction with increasing alteration intensity of the associated host rock (Fig. 3). As demonstrated in mass-balance modeling results, this progression is dependent upon the abundance of pyrite and other base-metal sulfides and the availability of acid-buffering minerals, especially calcite. Oxidation of pyrite, and presumably other sulfide minerals, causes naturally occurring acid water. Aluminum is dissolved as a product of the acid weathering of aluminosilicate minerals while most dissolved iron enters the water through the oxidation of pyrite. Dissolved copper and zinc in natural waters originate mostly from the oxidation of vein and disseminated base-metal sulfides such as enargite, zinc-rich tetrahedrite and sphalerite; whereas, pyrite oxidation contributes very little in terms base-metal content.

\section{REFERENCES}

Bove, D.J., K. Kon, K.E. Budding, J.F. Slack, and R.A. Yeoman, 1999. Geochronology and geology of late Oligocene through Miocene volcanism and mineralization in the western San Juan Mountains, Colorado: U.S. Geological Survey Open-File Report 99-347.

Bove, D.J., W.G. Wright, M.A. Mast, and D.B. Yager, 1998. Natural contributions of acidity and metals to surface waters of the upper Animas River watershed, Colorado. In Science for watershed decisions on Abandoned Mine Lands-Review of Preliminary Results, Denver, Colorado, ed. D.A. Nimick and P. von Guerard, U.S. Geological Survey Open-File Report 98-297.

Bove, D.J., R.O. Rye, and K. Hon, 1990. Evolution of the Red Mountain alunite deposit. U.S. Geological Survey Open-File Report 90-0235.

Burbank, W.S., and R.G. Luedke, 1964. Geology of the Ironton Quadrangle, Colorado. U.S. Geological Survey Geologic Map GQ-291.

Burbank, W.S., and R.G. Luedke, 1969. Geology and ore deposits of the Eureka and adjoining districts, San Juan Mountains, Colorado. U.S. Geological Survey Professional Paper 535.

Burbank, W.S., R.G. Luedke, and L.S. Ward, 1972. Arsenic as and indicator element for mineralized volcanic pipes in the Red Mountains area, western San Juan Mountains, Colorado. U.S. Geological Survey Bulletin 1364.

Eberl, D.D., R. Nüesch, V. Sucha, and S. Tsipursky, 1998. Measurement of fundamental illite particle thicknesses by X-ray diffraction using PVP-10 intercalation. Clays and Clay Minerals, 46:89-97.

Eberl, D.D., J. Srodoń, M. Lee, P.H. Nadeau, and H.R. Northrop, 1987. Sericite from the Silverton caldera, Colorado-Correlation among structure, composition, origin, and particle thickness. American Mineralogist, 72:914-934.

Fisher, F.S., and W.P. Leedy, 1973. Geochemical characteristics of mineralized breccia pipes in the Red Mountain district, San Juan Mountains, Colorado. U.S. Geological Survey Bulletin 1381. 
Gilzean, M.N., 1984. Nature of a deep hydrothermal system, Red Mountain district, Colorado. M.Sc. thesis, University of California at Berkeley.

Gray, J.E., and M.F. Coolbaugh, 1994. Geology and geochemistry of Summitville, Colorado-An epithermal acid-sulfate deposit in a volcanic dome. Economic Geology, 89:1906-1923.

King, W.H., and P.T. Allsman, 1950. Reconnaissance of metal mining in the San Juan Region, Ouray, San Juan, and San Miguel Counties, Colorado. U.S. Bureau of Mines Information Cicular 7554.

Lipman, P.W., F.S. Fisher, H.H. Mehnert, C.W. Naeser, R.G. Luedke, and T.A. Steven, 1976. Multiple ages of mid-Tertiary mineralization and alteration in the western San Juan Mountains, Colorado. Economic Geology, 71:571-588.

Lipman, P.W., T.A. Steven, R.G. Luedke, and W.S. Burbank, 1973. Revised volcanic history of the San Juan, Uncompahgre, Silverton, and Lake City calderas in the western San Juan Mountains, Colorado. U.S. Geological Survey Journal of Research, 1:627-642.

Matlock, J., and V.F. Hollister, 1990. Discovery of the Red Mountain No. 3 ore body, Ouray County, Colorado, In Discoveries of valuable minerals and precious metal deposits related to intrusions and faultsLittleton, Colorado, ed. V.F. Hollister, Society for Mining, Metallurgy, and Exploration Incorporated.

Moore, D.M., and R.C. Reynolds, Jr., 1989. X-ray diffraction and the identification of clay minerals. New York: Oxford University Press.

Nash, J.T., 1975. Fluid-inclusion study of vein, breccia pipe, and replacement ores, northwestern, San Juan Mountains, Colorado. Economic Geology, 70:1038-1040.

Nash, J.T., 1999. Geochemical investigations and interim recommendations for priority abandoned mine sites, BLM lands, upper Animas watershed, San Juan County, Colorado. U.S. Geological Survey Open-File Report 99-323.

Nimick, D.A., and P. von Guerard, 1998. Science for watershed decisions on abandoned mine lands-review of preliminary results. U.S. Geological Survey Open-File Report 98-297.

Plummer, L.N., R.C. Prestemon, and D.L. Parkhurst, 1994. An interactive code (NETPATH) for modeling NET geochemical reactions along a flow PATH, version 2.0. U.S. Geological Survey Water-Resources Investigations Report 94-4169.

Ransome, F.L, 1901. A report on the economic geology of the Silverton quadrangle, Colorado. U.S. Geological Survey Bulletin 182.

Schwarz, T.E., 1883. Remarks on occurrences of ore in mines near Silverton. Colorado Scientific Society Proceedings, 1:134-144.

Slack, J.F., and P.W. Lipman, 1979. Chronology of alteration, mineralization, and caldera evolution in the Lake City area, western San Juan Mountains, Colorado. In Papers on mineral deposits of western North America, ed. J.D. Ridge, 151-158. Nevada Bureau of Mines Geology Report 33.

Wirt, L., K.J. Leib, D.J. Bove, M.A. Mast, J.B. Evans, and G.P. Meeker, 1999. Determination of chemicalconstituent loads during base-flow and storm runoff conditions near historical mines in Prospect Gulch, upper Animas River watershed, southwestern, Colorado. U.S. Geological Survey Open-File Report 99-159. 


\title{
Pre-Mining Bed Sediment Geochemical Baseline in the Animas River Watershed, Southwestern Colorado
}

\author{
Stanley E. Church', David L. Fey', and Robert Blair ${ }^{2}$
}

\begin{abstract}
Determination of the pre-mining geochemical baseline in bed sediments in watersheds impacted by historical mining activity is important in establishing watershed restoration goals. We have developed methods to solve this problem in the Animas River watershed, southwestern Colorado, using geomorphologic mapping to identify terraces that contain pre-mining sediments. Following a systematic evaluation of possible sites, we collected samples of pre-mining sediments in gravel deposits from 21 sites throughout the watershed. Geochemical analysis of individual layers has produced a chemical stratigraphy that can be tied to the historical record through geochronological and dendochronological studies.

Analysis of geochemical data, when coupled with the historical record, clearly shows that there has been a major impact on the geochemistry in bed sediments in the active stream channel by past mining activities. Historical mining has resulted in a substantial increase in metals in the very fine sand to clay-sized component of the bed sediment of the upper Animas River, and Cement and Mineral Creeks, which are the major tributaries of the Animas River. Enrichment factors for metals in modern bed sediments, relative to the pre-mining sediments, range from 1 to 6 for arsenic, 1 to more than 10 for cadmium, 1 to about 15 for copper, 1 to more than 25 for lead, 1 to more than 10 for silver, and 1.6 to more than 12 for zinc. The pre-mining bed sediment geochemical baseline is high relative to average crustal abundance values of many metals. The Animas River watershed above Silverton, Colorado would be readily identified as a highly mineralized area suitable for mineral exploration if it were not disturbed by mining.
\end{abstract}

\section{INTRODUCTION}

Determination of pre-mining metal concentrations in bed sediments in watersheds affected by historical, inactive mines is necessary to help define achievable remediation and restoration goals of the Federal landmanagement agencies (FLMA). We estimate that more than forty percent of the headwaters in watersheds in or west of the Rocky Mountains have been impacted to some degree by past mining activities (Church et al. $1998 \mathrm{~b}$ ). The determination of water quality, stream habitat and aquatic community structure that existed prior to mining are needed to define pre-mining conditions and guide watershed restoration. Furthermore, the suspended- and bed-sediment geochemistry degrade aquatic habitat and impact the food chain (Milhous, 1999; Besser et al. 1998). Because there are no direct measures of water quality prior to historical mining activities, an alternative approach must be found to evaluate pre-mining stream and aquatic conditions.

A new approach has been developed to determine the pre-mining geochemical baseline conditions in the Animas River watershed. Trace-metal concentrations in the iron oxyhydroxide and oxyhydroxysulfate minerals that precipitated out of stream waters as colloidal fractions and were preserved in the fluvial sedimentological record (Church et al. 1997) provide an indirect measure of pre-mining water quality. We have applied geomorphologic mapping methods to determine the relative ages of various gravel deposits preserved within the stream reaches. Dendrochronology, historical records, and limited radiometric dating have also been used to provide minimum ages of the terrace deposits. The river-terrace deposits are generally erosional remnants of fluvial gravel deposits. We sampled gravels in terraces preserved above the maximum flood-stage level, as determined by overbank deposits left by the 1911 Gladstone flood, which is the historical flood of record. We have determined trace-element concentrations in these bed sediments using the same sampling, processing, and analytical methods that were used to determine trace-element concentrations in modern bed sediments (Church et al. 1997). Pre-mining terrace-sediments have proven relatively easy to identify in the watershed, although they are not readily available everywhere within the watershed.

1 U.S. Geological Survey, Mineral Resources, Denver, Colorado

2 Fort Lewis College, Dept. of Geology, Durango, Colorado 


\section{Geology of the Study Area}

The Animas River drainage basin has its headwaters in the mountainous terrain above Silverton, Colorado (fig. 1) and drains south into the San Juan River in northern New Mexico. Elevations range from more than $4,000 \mathrm{~m}(13,000 \mathrm{ft})$ at the headwaters to less than $1,800 \mathrm{~m}(6,000 \mathrm{ft})$ at the confluence with the San Juan River south of Aztec, New Mexico. The major population center in the watershed is the city of Durango, Colorado (fig. 2).
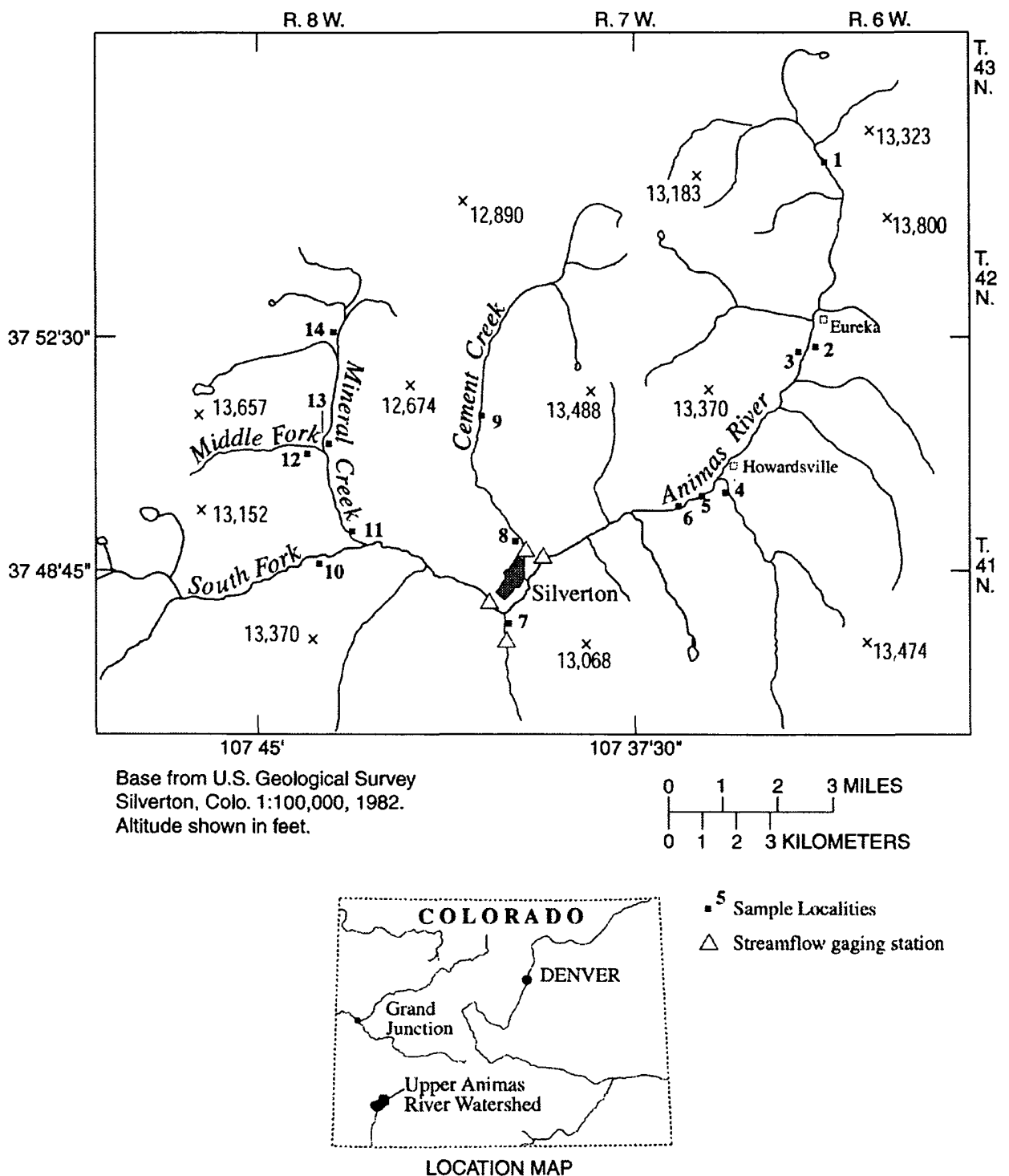

- Sample Localities

$\triangle$ Streamflow gaging station

Figure 1 Map of the upper Animas River watershed (defined as the area of the watershed above the confluence of the Animas River with Mineral Creek) showing localities of samples used to determinine pre-mining geochemical conditions. The map area shows the upper Animas River watershed, which is the primary focus of the current study. Additional samples are discussed in the text from localities as far downstream as Durango (S-21), about 75 river $\mathrm{km}$ south of Silverton, Colorado on the Animas River (fig. 2). 


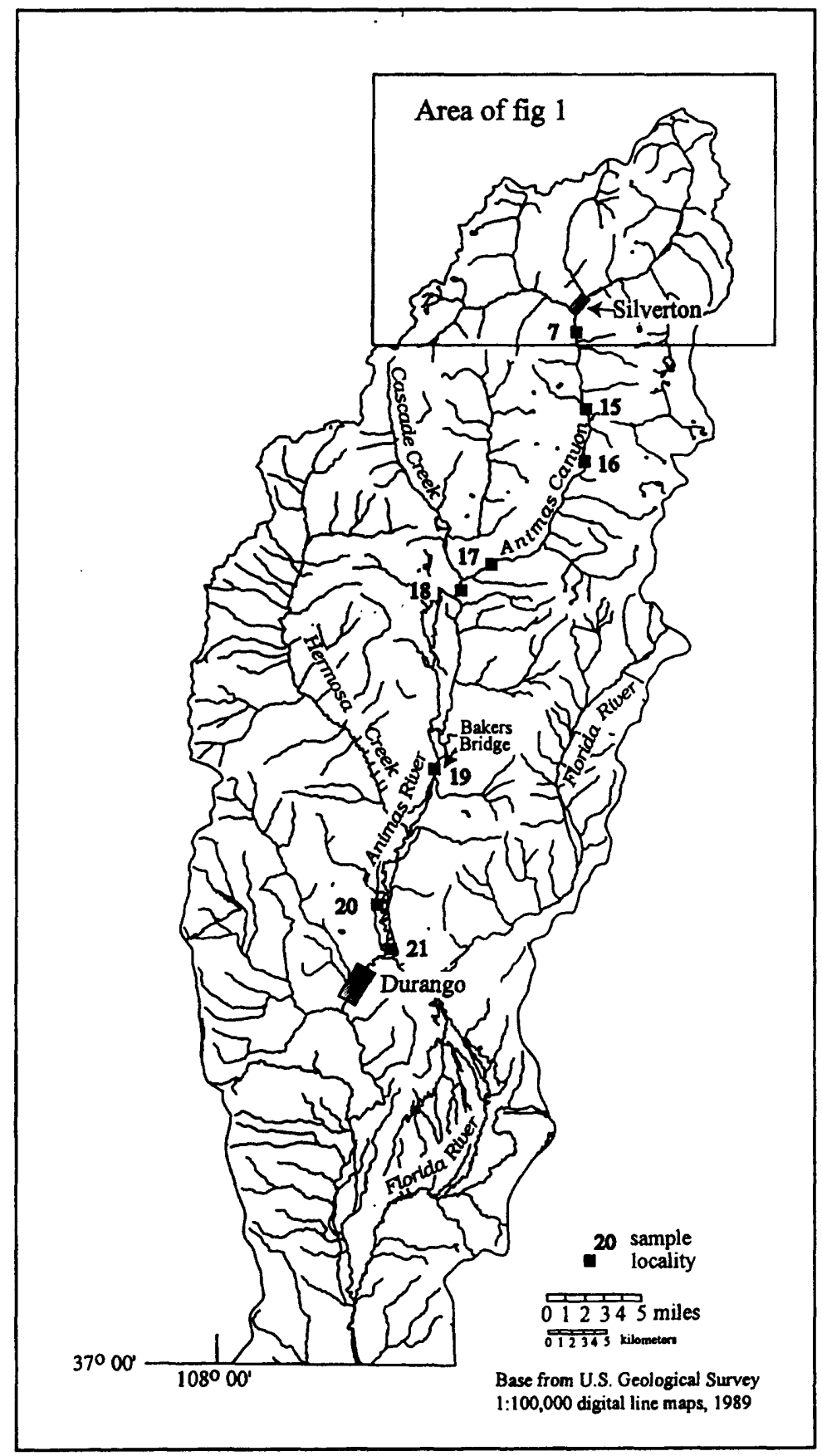

Figure 2 Map of the Animas River watershed showing localities of samples used to determinine premining geochemical conditions. The map area shows the Animas River watershed from its headwaters to the Colorado state line. Samples are shown in the Animas River below the area of fig. 1. Localities are as far downstream as Durango (S-21), about 75 river $\mathrm{km}$ south of Silverton, Colorado on the Animas River. Bakers Bridge (S-19) is located at the base of the Animas Canyon section about 50 river $\mathrm{km}$ south of Silverton, Colorado. 
The headwaters of the Animas River watershed are underlain by Tertiary igneous intrusive and volcanic rocks that formed as a result of a late Tertiary age episode of andesitic to dacitic volcanism, followed by a later episode of ash-flows, lava flows and intrusions of dacitic to rhyolitic composition (Lipman et al. 1976) forming the Silverton caldera. Pervasive and intense hydrothermal alteration and mineralization events postdate the formation of the Silverton caldera by several million years (Casadevall and Ohmoto, 1977). This area of the Animas River watershed above Silverton has been extensively fractured, altered, and mineralized by Miocene hydrothermal activity. Precambrian rocks crop out in the eastern part of the Animas River drainage basin in the Animas Canyon reach south of Silverton forming the high rugged mountains in the Weminuche Wilderness. Successive sections of Paleozoic, Mesozoic, and Tertiary sedimentary rocks crop out in the southern part of the drainage basin, near Durango, Colorado (Tweto, 1979).

Placer gold was discovered in 1860 on Arrastra Creek above Silverton by soldiers exploring the Bakers Park area, which later became the site of the town of Silverton, Colo. Following the signing of a treaty with the Ute Indians in 1873, between 1,000 and 1,500 mining claims were staked in the Animas River watershed upstream from Silverton. Mining activity spread rapidly throughout the area (Bird, 1999). The railroad was brought up from Durango in 1882 providing cheap transportation for ore concentrates from the many mills in and above Silverton to the smelters in Durango (Sloan-and Skowronski, 1975). Mining continued in the Animas River watershed until 1991 when the Sunnyside Mine closed. The Sunnyside Gold Corp. initiated widespread remediation activities throughout the watershed in 1994.

Mineral deposits in the area include the chimney deposits associated with intrusives at Red Mountain located in the headwaters of Mineral Creek, which are arsenic rich and contain arsenopyrite and tetrahedrite. The major mineral production was from the base- and precious-metal polymetallic vein deposits in the Eureka graben located between the upper Animas River and Cement Creek (fig. 1). Additional preciousmetal production occurred in the South Silverton mining district located south of the upper Animas River southeast of Silverton (Burbank and Luedke, 1968; Leedy, 1971; Casadevall and Ohmoto, 1977). All of the mineral deposits contain pyrite, chalcopyrite, sphalerite, and galena. Low-grade porphyry molybdenum deposits have been identified by drilling in the Mineral Creek area (Tom Casadevall, oral commun., 1996).

\section{Geomorphology of Fluvial Deposits}

Sediment samples collected for the determination of the pre-mining geochemical baseline are from fluvial sand and gravel deposits preserved in stream terraces. Fluvial-deposits consist of gravels that were transported as bed load and deposited in stream beds and on bars, and finer sediments that were transported in suspension and often deposited in overbank settings. These sediments are found in the active stream channels and floodplains, but are also found in stream terraces. Stream terraces are former floodplains no longer constructed and maintained by the stream. They were abandoned because the stream became incised, because of climate change or some other reason, and thus were left elevated above the active channel and floodplain. An understanding of the geomorphic evolution of the stream valleys and these terraces is necessary to interpret the geochemical data. Surficial deposits of the Animas River watershed were mapped using color aerial photographs (Blair, 1998). A surficial geologic strip map of the major tributaries, representing an area about one kilometer in width and extending about $125 \mathrm{~m}$ up the sides of the drainages above the active floodplain, has been completed for the Animas River and Cement and Mineral Creeks.

The upper Animas River and Mineral Creek (fig. 1) follow the Silverton caldera ring fracture system. The volcanic rocks were rapidly weathered and eroded as a result of the intense fracturing and hydrothermal alteration. Today, surficial deposits in the stream valleys are dominantly glacial, fluvial, and colluvial. Although there have been multiple glacial episodes over the past two million years (Atwood and Mather, 1932; Gillam, 1998), only vestiges of the most recent glaciation (maximum extent about 18,000 years BP) are present today. For example, Mineral Creek and the upper Animas River have classic U-shaped valleys and both contain morainal deposits (Blair, 1998).

In the study area there have been two simultaneous modes of operation of the fluvial system during the Holocene. In most stream reaches, there has been episodic stream incision followed by stability and floodplain formation, and in some of those reaches terrace gravel deposits are preserved. Other stream reaches have been dominated by slow aggradation of channels and floodplains, and terrace gravel deposits are absent. In a detailed trench study of the Animas River floodplain below Eureka (fig. 1, site 3), Vincent et al. (1999) demonstrated that for at least the past 2,000 years the valley floor has aggraded at a rate of about 1 m per 1,000 years. Between the period from 1900-1930, an additional meter of aggradation occurred in the Animas River. More than 2 million tons of tailings were added to the Animas River from the initial stamp and subsequent flotation mills at Eureka. Only a fraction of these tailings are now stored in the reach below Eureka. The rest of the mill tailings have been flushed downstream and, along with tailings produced by the numerous other mills in the stream reach, form a large sink of metal-laden sediment that raised the concentrations of metals in historical stream deposits. The objective of this study is to identify pre-mining 
sediment deposited prior to mining and milling, and isolated from the stream and thus not contaminated by tailings.

Field investigations indicate that fluvial gravel deposits preserved in terraces at greater than two meters above the active stream level are probably older than 1860 . The fluvial sediments in these terraces were laid down prior to mining activity and preserve the pre-mining geochemical baseline for the representative drainage, assuming no post-depositional human impact has occurred. These older terraces are relatively rare in narrow canyons less than $100 \mathrm{~m}$ wide, such as the area south of Howardsville above Silverton, and north of Eureka (fig. 1). The narrow canyons act as high-energy funnels during major stream flow events that flush out and redistribute previously deposited sediment. Where valleys widen to several hundred meters, older gravel terraces are usually preserved; for example, at Bakers Park where the town of Silverton is located, along upper Mineral Creek (sites 13-14, fig. 1), and in selected reaches of the Animas Canyon between Silverton and Durango. Historical evidence of the age of these elevated remnant terrace deposits can be deduced from a study of the overbank deposits resulting from the Gladstone storm of October 5, 1911, the largest historic flood on record in the upper Animas River watershed. The Gladstone storm reworked existing alluvial channel sediment and deposited overbank sediments on midstream bars and new floodplain deposits at elevations less than two meters above the active floodplain in several localities in the upper Animas River watershed (Pruess, 1996). Thus, terraces elevated more than two meters above the active floodplain are both prehistorical in age and would not be contaminated by flood transported tailings and mine wastes.

Human impact on the floodplain in the Animas River watershed has been significant, particularly on the active floodplain. It is estimated from the geomorphic mapping studies that eighty to ninety percent of the entire channel length of the Animas River has been altered in some way by human activity (Blair, 1998). The floodplain between Howardsville and Eureka has been impacted directly as shown by the dramatic change in aggradation at the trench site (fig. 1, site 3) below Eureka (Vincent et al. 1999). A great deal of sediment movement over the past 130 years occurred as a result of milling at Eureka between 1900 and 1930. Aggradation in the braided section of the Animas River has raised the base of the streambed by about one meter, obliterating the pre-mining stream morphology, destroying the willow carrs that provide bank stability and riparian habitat (Vincent et al. 1999) and destroying the winter aquatic habitat (Milhous, 1999).

Another example of human impact on the active floodplain occurred due to aggressive stoping at the Sunnyside Mine beneath an alpine lake in 1978. This activity resulted in collapse of the mine roof and lake floor into the mine, draining the water from Lake Emma into the Sunnyside Mine (Bird, 1999). The flush of sediment-laden waters from the Gladstone portal down Cement Creek coated the entire active floodplain with sediment. Deposits from this event can be found on gravel terraces that are generally one to two feet above the active flood plain of Cement Creek.

\section{METHODS}

\section{Field Sampling Methods}

Using the geomorphological maps to guide our field sampling, we walked the segments of the river channels where pre-mining sediments might be preserved in old terrace deposits and sampled them at a number of sites in the watershed. Sample localities above the confluence of the Animas River with Mineral Creek are shown schematically on fig. 1 and below Silverton on fig. 2. Terrace deposits were also sampled at several sites in the Animas Canyon, usually at sites in abandoned channels between Silverton and Bakers Bridge, about 25 $\mathrm{km}$ upstream from Durango Colorado. Whenever possible, terrace deposits were sampled beneath old large trees (generally Engelmann Spruce). The trees were cored if live, or sampled if dead, for dendrochronological determination of the minimum age of the terrace deposits. Historical photographs, records, or other documents were also used to determine the minimum age of the terrace deposits (table 1).

The terrace deposits are generally composed of poorly sorted fluvial gravels containing lithic clasts ranging in size up to $30 \mathrm{~cm}$ in diameter. Because no discernable stratigraphy was preserved, sections were sampled in 15 to $30 \mathrm{~cm}$ intervals throughout the exposed section. We dug back into the terrace deposit at least $20 \mathrm{~cm}$, carefully removing any materials that might have been deposited on the surface of the bank by historical flood deposits that might result in sample contamination of the pre-mining gravel deposits even though we were confident that we were sampling above the stage of all historical floods. At some sites, it was necessary to sample terrace gravels at lower elevations. Here, the material on the tops of the banks was also removed unless covered by a well-developed soil horizon to prevent contamination by recently deposited gravels and silts on top of the gravel banks. Metal contamination from historical mining activities was readily shown at many of these sites in the lower terraces and these data were not used to determine the pre-mining baseline. A minimum of three samples at each site was usually taken to provide some statistical measure of precision. Where the analytical results were not consistent between samples collected at the same site, the results were not used to determine the pre-mining geochemical baseline. The gravel samples were sieved in the field to pass a 2-mm stainless steel screen, and sent to the laboratory for further processing. In the laboratory the samples were air died and sieved to pass 100 mesh ( $<150$ micrometers), and split in the same 


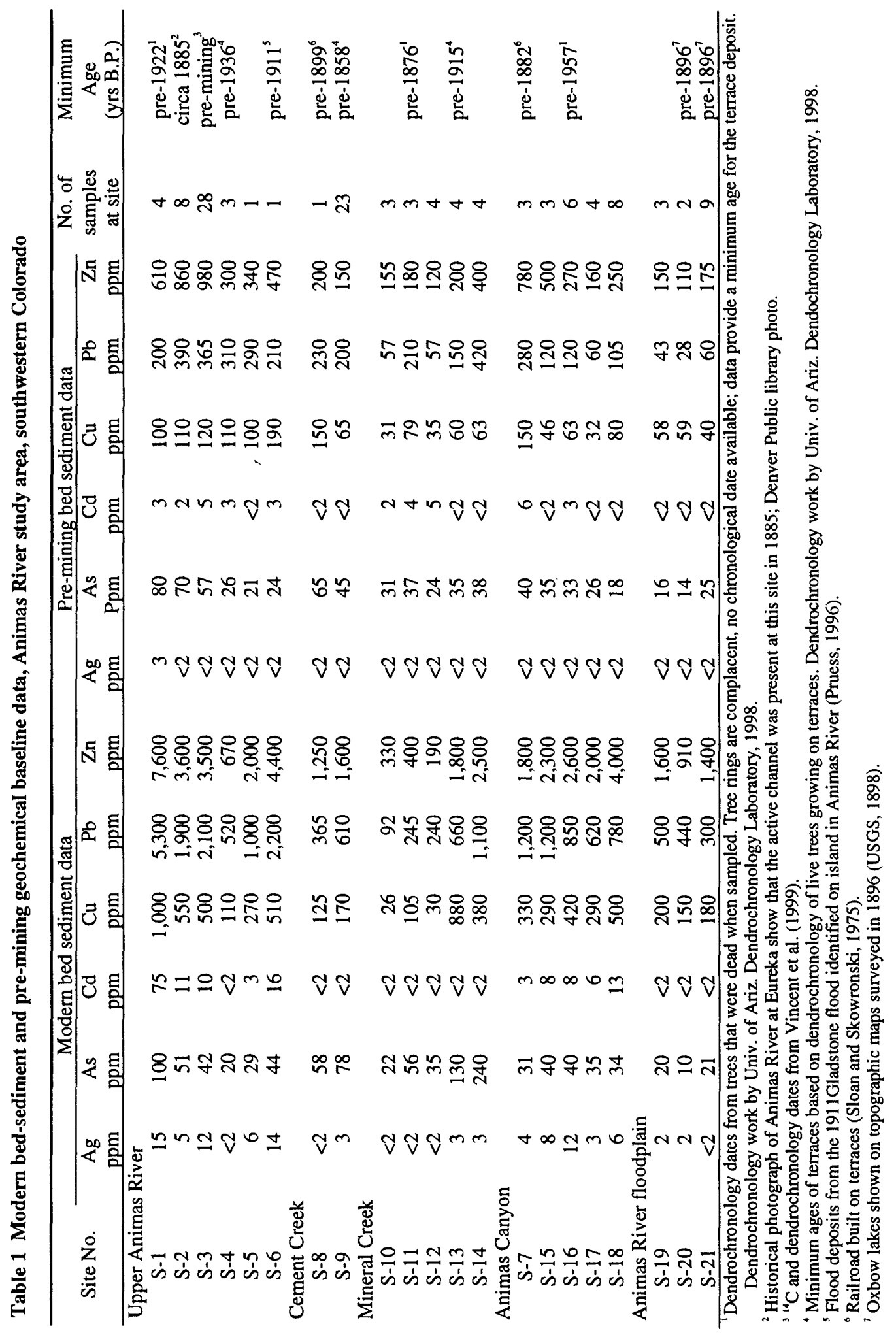


manner as the stream sediments studied by Church et al. (1997). The sample material analyzed constitutes the very fine sand, silt, and clay-fractions of the pre-mining fluvial sediments.

Below Bakers Bridge, the Animas River is a meandering river with numerous oxbow lakes. We sampled the fluvial deposits in these oxbow lakes, one of which was active circa 1896 just north of the town of Durango in what was known at the turn of the century as the town of Animas City (S-21, shown in the historical photographs by Whitman Cross, in Atwood and Mather, 1932, plate 25; U.S. Geological Survey, 1898). Five-cm diameter cores of fluvial sediments up to depths of three meters were taken from these oxbow lakes. The cores were subdivided into subsamples along stratigraphic boundaries for analysis. Sandy layers were sieved as described above prior to chemical analysis.

\section{Analytical Methods}

Samples from the cores and stratigraphic intervals sampled in the gravels were analyzed using two different digestion procedures: a mixed-acid total digestion and a weak partial-dissolution extraction. Both were analyzed by inductively-coupled plasma atomic emission spectroscopy (ICP-AES; D.L. Fey, unpub. data, 1997-1999).

The total digestion procedure utilizes a combination of $\mathrm{HCl}, \mathrm{HNO}_{3}, \mathrm{HClO}_{4}$, and $\mathrm{HF}$ acids applied to $0.2 \mathrm{~g}$ of sample (Briggs, 1996). The method is very effective in dissolving sulfide, oxide, and most silicate minerals. The resulting solution was analyzed for 40 elements using ICP-AES. Laboratory duplicates were analyzed to assess precision, and three standard reference materials (SRM's) were analyzed with each set of samples to assess accuracy. The reference materials were NIST-2704, NIST-2709 and NIST-2711, available from the National Institute of Standards and Technology (NIST, 1993a, 1993b, and 1993c).

Geochemical data from partial digestions can be quite informative in the study of the release metals bound within different mineral phases (Chao, 1984). Bed sediments can be enriched with metals- released during weathering, or the grain surfaces may be coated by iron- and manganese-oxides associated with acidic drainage. We used a warm-acid leach $\cdot\left(2 \mathrm{M} \mathrm{HCl}-1 \% \mathrm{H}_{2} \mathrm{O}_{2}\right.$ at $\left.50^{\circ} \mathrm{C}\right)$ to dissolve hydrous amorphous iron- and manganese-oxides or sediment-coatings containing sorbed metals (see appendix II and III in Church et al. 1993). In this procedure, a 2-g sample is gently agitated and leached with $15 \mathrm{ml}$ of the solution for three hours, centrifuged, and analyzed for 35 elements by ICP-AES. Replicates and the same reference materials were also analyzed with each sample set to assess analytical quality and reproducibility. Results from the leach digestion indicate the portion of the metals that are associated with the colloidal phase of the sediments.

\section{RESULTS}

Geochemical data from total digestions of 128 samples from the 21 pre-mining geochemical baseline sites are summarized in table 1. Comparisons can be made with trace-element values determined from modern bed sediments and the 21 pre-mining geochemical baseline sites from the same localities. Enrichment factors were calculated by dividing the concentraton measured for the trace-element in modern sediments by the concentration measured for the trace-element in the pre-mining sediment at that site from the total digestion data (table 1). Enrichment factors for arsenic range from about 1 to 6.3 and average 1.5, enrichment factors for copper range from about 1 to 15 and average 4.5, enrichment factors for lead range from about 1 to 26 and average 6.8, and enrichment factors for zinc range from 1.6 to 16 and average 7. Cadmium and silver are also enriched (table 1), but average values cannot be determined because the concentrations for these two metals in the pre-mining bed sediments often were below the limit of detection. Geochemical data for the Animas River are shown in figure 3 for copper, figure 4 for lead, and figure 5 for zinc. Zero on the $x$-axis scale for figs. 3-5 is not defined; the confluence of Mineral Creek and the Animas River was assigned an arbitrary value of $25 \mathrm{~km}$. Diagrams for arsenic show similar behavior as lead in the Mineral Creek drainage. Abundances of metals determined in modern bed sediments from tributary streams are also plotted in the figures for comparison with the pre-mining geochemical baseline. Some terrace gravels plot below the premining geochemical baseline; these sites appear to be dominated by alluvium from a particular tributary rather than from the Animas River and are not included in table 1. Many of the tributary streams in the mining district have prospect pits or historical mines in the watersheds, but some do not. Trace-element concentrations in bed sediments from tributaries in the upper Animas River watershed having little or no historical mining activity are very comparable to the pre-mining geochemical baseline concentrations determined from the pre-mining sand and gravel deposits preserved in the terraces and confirm the premining baseline determined from the pre-mining terrace gravels above Silverton. South of site S-7, historical mining activity has had a minimal impact on metal concentrations in the tributary stream drainages as only a few small prospects occur outside the Silverton caldera.

The $\mathrm{pH}$ of stream waters greatly affects the capacity of a stream to carry metals in the dissolved phase. Sorbtion of trace elements onto iron colliods and transport as suspended sediments which eventually precipitate out to become part of the bed sediment load (Smith et al. 1992) occurs when the pH of the stream is above about 4 , whereas aluminum colloids will form above a $\mathrm{pH}$ of about 5 . This transport phenomenon 
greatly impacts the transport of metals in acidic stream waters affected by mining (Church et al. 1997). The relative contributions of metals in bed sediments from each of the three stream reaches in the Animas River watershed above Silverton (fig. 1) can be estimated by comparing the data in table 1 . There is a substantial increase in the concentrations of copper, lead, and zinc in modern bed sediments that is directly attributable to historical mining activity in the watershed of the upper Animas River. On the basis of the five samples from the sites on the upper Animas River (S-1 to S-3, S-5 and S-6; fig. 1), the concentrations of lead in bedsediments today has been increased at least by a factor of five over that in the pre-mining bed sediments, the concentrations of zinc in bed sediments today has increased by a factor of six, and the concentrations of copper in bed sediments today has increased by a factor of four. The $\mathrm{pH}$ of water in much of the upper Animas River was probably higher than the 6.6 measured at low flow (Church et al. 1997).

In contrast, the $\mathrm{pH}$ of water in Cement Creek today during low flow was 3.8 at site S-8 (fig. 1) at the confluence with the upper Animas River and a substantial component of the total metal load is carried in the dissolved phase or in the colloidal phase (Kimball et al. 1999; Schemel et al. 1999; Church et al. 1997). The large amount of metals in the bed sediments contributed by Cement Creek is largely due to the deposition of colloids formed in the mixing zone below the confluence of Cement Creek with the Animas River. Site S-9 (fig. 1) is a terrace deposit formed after the breakout of an old lake formed by damming of Cement Creek. Radiocarbon dates of the peats formed in this lake range from 700 to 2,500 years B.P. Copper, lead, and especially zinc concentrations are substantially enriched in bed sediments today at the same location relative to pre-mining geochemical baseline values obtained from the gravels in this terrace deposit.

The $\mathrm{pH}$ of water in Mineral Creek today at the confluence with the Animas River was 6.4 during low flow at S-11 (Church et al. 1997). Copper, lead, zinc, and especially arsenic are enriched in modern bed sediments at the headwaters of Mineral Creek (fig. 1; S-13 and S-14). The source of the high arsenic is tetrahedrite and arsenopyrite in chimney deposits in the headwaters of Mineral Creek (Burbank et al. 1972; table 1, S-13 and S-14). The concentrations of metals in the bed-sediment are substantially diluted by the time they reach the confluence with the South Fork of Mineral Creek (fig. 1, S-11) with enrichment factors of 1.5 to 2 for copper, lead, and zinc, and a factor of about 5 for arsenic (table 1).

The Animas Canyon reach (about $50 \mathrm{~km}$ in length) is a steep-walled canyon cut in unmineralized preCambrian rock. We were able to find isolated gravel terraces in abandoned river channels in several places where the Animas Canyon widens. In some places, the abandoned streambed is more than one meter above the low-flow water level of the Animas River in the Animas Canyon. Pre-mining terrace gravel deposits are often more than two meters above the low-flow water level. The $\mathrm{pH}$ of the water in the Animas River today at low flow varied from 6.6 at S-7, 7.9 at Bakers Bridge (S-19), and 7.5 at Durango (S-21, fig. 2). Copper and zinc are sorbed to the colloidal phase during transport in the Animas Canyon reach and are transferred to the bed-sediment load, settling out from the suspended colloidal load in slow moving stream reaches (Church et al. 1997). Enrichment of copper ranges from 6 to 9 , lead from 7 to 10 , and zinc from 4 to 16 relative to bedsediment loads prior to historical mining activity. Modern bed sediments from tributary streams in this reach largely drain the pre-Cambrian rocks and metal concentrations in bed sediments from these tributaries are near average crustal abundance levels (Church et al. 1997). There is little dilution of the metal concentrations in the bed sediments of the Animas River by sediments locally derived in the Animas Canyon reach.

In the reach below Bakers Bridge to Durango, the Animas River is a meandering river with a welldeveloped floodplain containing many old oxbow lakes (USGS, 1898). The gradient of the Animas River in this reach is much lower than in the Animas Canyon (Church et al. 1997), and metal enrichment factors in bed sediments today range from 2.5 to 4.5 for copper, 5 to 16 for lead, and 8 to 10.7 for zinc. Tributary streams drain areas underlain by Paleozoic and Mesozoic sedimentary rocks. Four oxbow lakes of at least three different ages were sampled at one site immediately above Durango, Colorado (S-21, fig. 2). The stratigraphic section from the youngest oxbow lake contains fluvial sediments that have elevated concentrations of $\mathrm{Ag}, \mathrm{As}, \mathrm{Cd}, \mathrm{Cu}, \mathrm{Pb}$, and $\mathrm{Zn}$ resulting from the transport and deposition of fluvial tailings in the Animas River, whereas the stratigraphic sections sampled in the older oxbow lakes at this site contain metal concentrations at or near crustal-abundance levels. South of Durango, at about 135 river km (figs. 3-5), the Florida River enters the Animas River bringing a large sediment load that reduces the metal concentrations in the bed sediments of the Animas River by a factor of two (Church et al. 1997). The Florida River largely drains a large geographic area underlain by unmineralized Tertiary sedimentary rocks that are readily eroded (Tweto, 1979).

\section{Pre-Mining Geochemical Baseline}

The pre-mining geochemical baseline in bed sediments in the area of the Animas River watershed north of Silverton is significantly elevated above normal crustal abundance values. Average crustal abundance values for the metals discussed here are: $\mathrm{Cu}_{\mathrm{cA}} 68 \mathrm{ppm}, \mathrm{Pb}_{\mathrm{cA}} 13 \mathrm{ppm}, \mathrm{Zn}_{\mathrm{cA}} 76 \mathrm{ppm}, \mathrm{As}_{\mathrm{cA}} 1.8 \mathrm{ppm}, \mathrm{Ag}_{\mathrm{cA}} 0.08 \mathrm{ppm}$, and $\mathrm{Cd}_{\mathrm{CA}} 0.16 \mathrm{ppm}$ (Fortescue, 1992). We infer from pre-mining geochemical baseline data summarized here that the mineral deposits were exposed or near the surface prior to exploitation by early miners. This is confirmed 

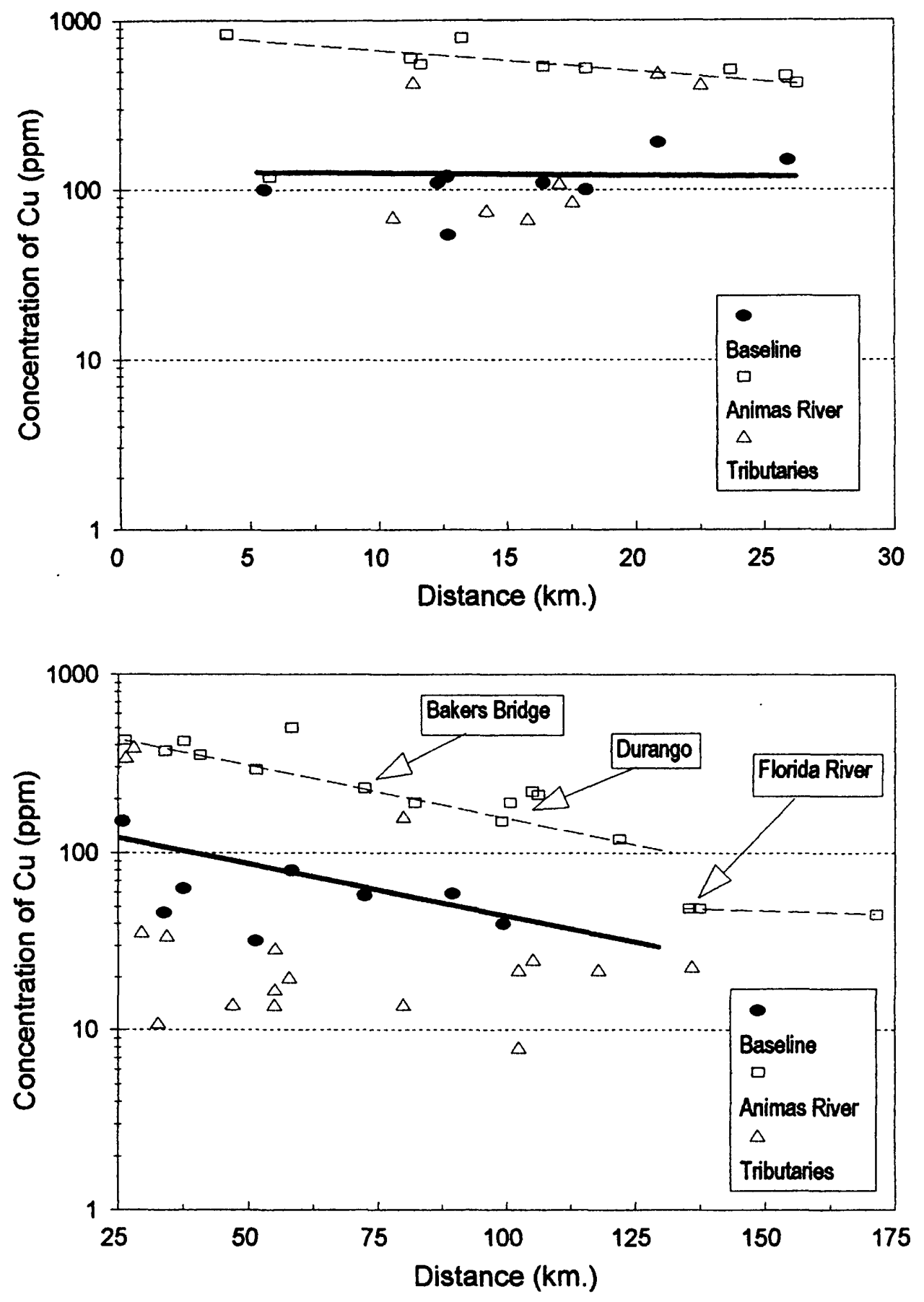

Figure 3 Copper $(\mathrm{Cu})$ distribution profile for the Animas River as a function of distance in river $\mathrm{km}$. Upper diagram shows the copper concentrations in modern sediments in the river above the Animas Canyon reach and in some tributary streams as well as the geochemical baseline from pre-mining terrace gravels. The lower diagram shows the impact of copper in bed sediments of the Animas River in the Animas Canyon (25-72 km) and the mature floodplain reach below Bakers Bridge $(72-170 \mathrm{~km})$. Both diagrams show the copper concentration data at the confluence of the Animas River and Mineral Creek (S-7 at 25 river km). 

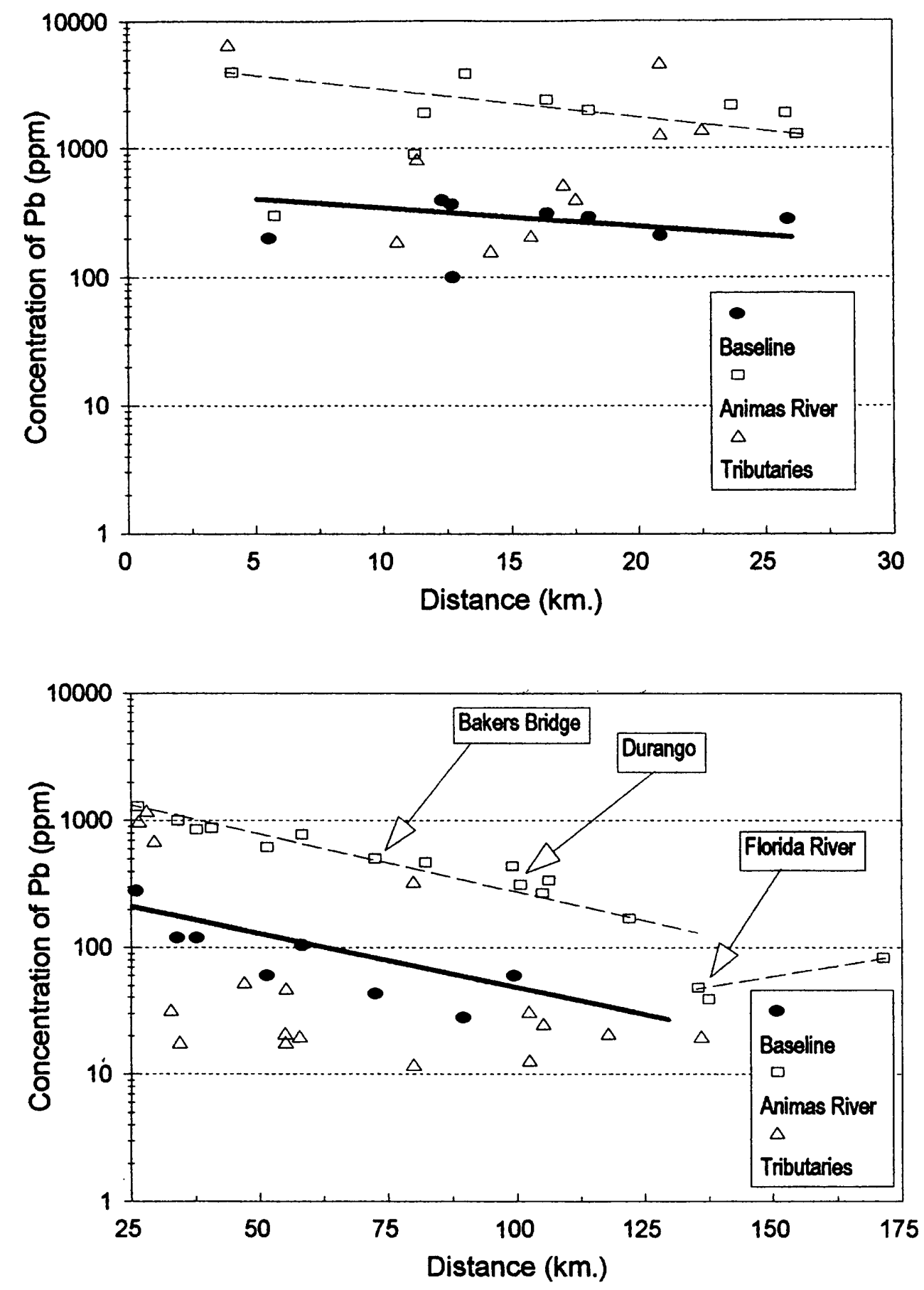

Figure 4 Lead $(\mathrm{Pb})$ distribution profile for the Aninas River as a function of distance in river kn. Upper diagram shows the lead concentrations in nodern sedinents in the river above the Animas Canyon reach and in sone tributary streams as well as the geochemical baseline fron pre-mining terrace gravels. The lower diagran shows the inpact of lead in bed sedinents of the Aninus River in the Aninuas Canyon and the floodplain below Bakers Bridge. Both diagrams show the lead concentration data at the confluence of the Aninuas River and Mineral Creek. 

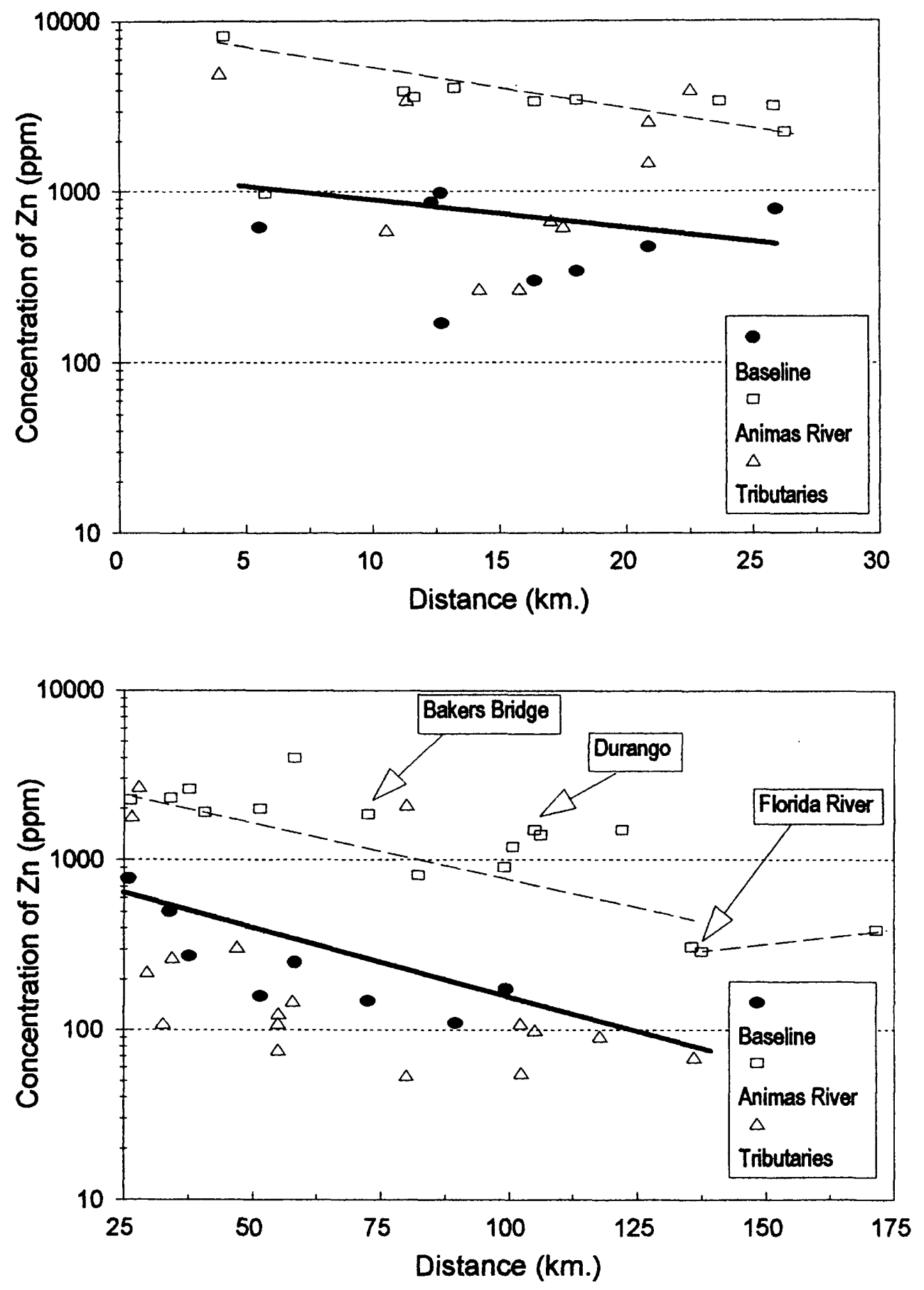

Figure 5 Zinc (Zn) distribution profile for the Animas River as a function of distance in river $\mathbf{k m}$. Upper diagram shows the zinc concentrations in modern sediments in the river above the Animas Canyon reach and in some tributary streams as well as the geochemical baseline from pre-mining terrace gravels. The lower diagram shows the impact of zinc in bed sediments of the Animas River in the Animas Canyon and the mature floodplain below Bakers Bridge. Both diagrams show the zinc concentration data at the confluence of the Animas River and Mineral Creek. 
by the descriptions of the Sunnyside vein exposures (Bird, 1999). The Animas River watershed would readily be identified today as a highly mineralized area suitable for mineral exploration had mineral development notalready occurred. Pre-mining water quality would have been affected by weathering of these near-surface mineral deposits, but further work is needed to quantify pre-mining water quality. Paleontological studies have shown no evidence of a pre-mining aquatic community. However, the energy of the stream environment represented by the pre-mining terrace gravels would not be conducive to preservation of delicate invertebrate remains and fish scales (Church et al. 1998a).

Estimates of the uncertainity on the pre-mining baseline concentrations are diffficult to quantify. There are three major sources of error: analytical error which can be readily determined from the analysis of the standard reference materials, sampling error which can be measured by the least-squares fit of the data in figures 3-5, and annual variation of the sediment distribution in the watershed which is a factor dependent upon the climatic conditions which affect stream flow. Of these, we can make reasonable estimates of the first two, but can only approximate the third, the climatic variability. Analytical error has been determined by replicate analyses of three reference standards from NIST (1993a, 1993b, 1993c) over the four-year life of the project. About fifty replicate analyses of each of the standards give relative standard deviations for copper of 5.4 to 6.9 percent, for lead of 5.9 to 7.6 percent for concentrations in excess of $40 \mathrm{ppm}$, and of zinc from 3.0 to 4.2 percent. Analytical error for individual determinations is about the size of the symbols used in figs. 3-5 We estimate that the sampling error, based on the annual variation from replicate samples taken over the four years of the study is about 30 percent, or five times the size of the symbols used in the figs 3-5. Pearson regression analysis of the $\log$ of the concentration of the metals copper, lead, and zinc versus distance gives $R$ values of $-0.68,-0.90$, and -.083 respectively. These correlations are relatively good for the lead and zinc data. The poorer correlation for copper is to be expected because these are not copper-rich deposits. Copper concentations in pre-mining sediments above $30 \mathrm{~km}$ (fig. 3) are nearly flat at about $125 \mathrm{ppm}$. The linear regression curves pass through most of the data points if one uses the estimates of sampling error, but the analytical errors are too small to significantly affect the regression analysis. In addition, one has no apriori reason to assume that the dispersion of metals downstream should follow a log-normal distribution, particularily given the very different hydrologic regimes represented by the Animas River below Silverton. In fact, the empirical evidence from the data suggest that the dispersion pattern is not log-normal because the pre-mining bed-sediment data from the Animas Canyon plot below the regression line. For this reason, we show the dispersion pattern above and below Silverton in two separate diagrams (figs. 3-5) and have plotted a best-fit line through the data rather than the linear regression through the entire data set.

\section{SUMMARY}

Geomorphologic mapping of the fluvial deposits in the study area has identified numerous sites where premining bed sediments have been preserved in terrace gravel deposits. We have examined many sites for depositional and stratigraphic relationships that typify terrace deposits that probably represent pre-mining conditions in the watershed. We have collected and analyzed fluvial sediments from more than 50 sites plus the trench site (site 3, fig. 1). Fluvial materials from these sites represent both pre-mining and historical bed sediments, overbank flood deposits (both pre-mining and historical), fluvial tailings deposits from different milling processes, pre-mining riparian habitat, and historical and currently active beaver ponds. More than 500 samples have been analyzed for total metal concentrations (D.L. Fey, unpub. data, 1998-99). We have determined the pre-mining geochemical baseline values at 21 sites within reasonable limits of reproducibility. Analysis of the geochemical data, when coupled with both the historical and geochronological record, clearly shows that there has been a major impact by historical mining activities on the geochemistry of the fluvial bed sediments. The impact of historical mining activity is recorded in the sedimentological record as shown by the study of sediments from the trench section (fig. 1, S-3; Vincent et al. 1999). Historical mining activity has resulted in a substantial increase in the concentrations of trace-elements associated with the mineral deposits produced in the very fine sand to clay-sized component of the bed sediments of the upper Animas River, and Cement and Mineral Creeks. Enrichment factors for metals in modern bed sediments, relative to pre-mining bed sediments, range from 1 to 6.3 for arsenic, 1 to more than 10 for cadmium, 1 to about 15 for copper, 1 to more than 25 for lead, 1 to more than 10 for silver, and 1.6 to more than 12 for zinc.

Restoration goals and objectives for the upper Animas River watershed must take into account the evidence from the pre-mining fluvial record, which indicates that bed-sediment trace-element concentrations were substantially lower than they are today. Furthermore, the profound changes in the ground-water hydrology and the substantial dispersed metal source in the fluvial sediments, caused by the industry practice of discharging mill tailings into mountain streams throughout the West prior to 1935 , are environmental impacts that have prolonged influence on the overall restoration plan for the upper Animas River watershed. Monitoring studies that focus on the impact of removing known point sources within the upper Animas River watershed would be required before it is feasible to determine the extent to which watershed restoration can approach the original pre-mining bed sediment geochemical baseline. 


\section{REFERENCES}

Atwood, W.W., and K.F. Mather. 1932. Physiography and Quaternary Geology of the San Juan Mountains, Colorado. U.S. Geological Survey Professional Paper 166.

Besser, J.M., W. Brumbaugh, S.E. Church, and B.A. Kimball. 1998. Metal uptake, transfer, and hazards in the stream food web of the upper Animas River watershed, Colorado. In Science for watershed decisions on abandoned mine lands: review of preliminary results, Denver, Colorado, February 4-5, 1998, eds. D.A. Nimick and P. von Guerard, 20. U.S. Geological Survey Open-File Report 98-297.

Bird, A.G. 1999. Silverton Gold, The story of Colorado's largest gold mine.

Blair, R. 1998. Progress report on surficial deposits and geomorphology of major drainages of the upper Animas River watershed, Colorado. In Science for watershed decisions on abandoned mine lands: review of preliminary results, Denver, Colorado, February 4-5, 1998, eds. D.A. Nimick and Paul von Guerard, 28. U.S. Geological Survey Open-File Report 98-297.

Briggs, P.H. 1996. Forty elements by inductively coupled-plasma atomic emission spectrometry. In Analytical methods manual for the Mineral Resources Program, ed. B.F. Arbogast, 77-94. U.S. Geological Survey Open-File Report 96-525.

Burbank, W.S., and R.G. Luedke. 1968. Geology and ore deposits of the San Juan Mountains, Colorado. In Ore Deposits of the United States, 1933-1967, ed. J. D. Ridge, 714-733. New York: Am. Inst. Mining, Metall., and Petrol. Eng.

Burbank, W.S., R.G. Luedke, and F.N. Ward. 1972. Arsenic as an indicator element for mineralized volcanic pipes in the Red Mountains area, western San Juan Mountains, Colorado. U. S. Geological Survey Bulletin 1364.

Casadevall, T., and H. Ohmoto. 1977. Sunnyside mine, Eureka mining district, San Juan County, Colorado: Geochemistry of gold and base metal ore deposition in a volcanic environment. Econ. Geol. 92: 12851320.

Chao, T.T. 1984. Use of partial dissolution techniques in geochemical exploration. J. Geochemical Expl. 20:101-135.

Church, S.E., C.E. Holmes, P.H. Briggs, R.B. Vaughn, J. Cathcart, and M. Marot. 1993. Geochemical and lead-isotope data from stream and lake sediments, and cores from the upper Arkansas River drainage: Effects of mining at Leadville Colorado on heavy-metal concentrations in the Arkansas River. U.S. Geological Survey Open-File Report 93-534.

Church, S.E., B.A. Kimball, D.L. Fey, D.A. Ferderer, T.J. Yager, and R.B. Vaughn. 1997. Source, transport and partitioning of metals between water, colloids, and bed sediments of the Animas River, Colorado. U.S. Geological Survey Open-File Report 97-151.

Church, S.E., D.L. Fey, and E.M. Brouwers. 1998a. Determination of pre-mining geochemical baseline using sediment cores from old terraces in the upper Animas River watershed, Colorado. In Science for watershed decisions on abandoned mine lands: review of preliminary results, Denver, Colorado, February 4-5, 1998, eds. D.A. Nimick and P. von Guerard, 40. U.S. Geological Survey Open-File Report 98-297.

Church, S.E., T.C. Sole, D.B. Yager, and A.M. McCafferty. 1998b. The role of geoenvironmental maps and statewide assessments in prioritizing watersheds for remediation of abandoned mine lands. In Science for watershed decisions on abandoned mine lands: review of preliminary results, Denver, Colorado, February 4-5, 1998, eds. D.A. Nimick and P. von Guerard, 4. U.S. Geological Survey Open-File Report 98-297.

Fortescue, J.A.C. 1992. Landscape geochemistry: retrospect and prospect-1990. Applied Geochem. 7:1-54.

Gillam, M. 1998. Late Cenozoic geology and soils of the lower Animas River Valley, Colorado and New Mexico. Ph.D. Dissertation, Univ. of Colorado, Boulder.

Kimball, B.A., R.L. Runkel, K.E. Bencala, and K. Walton-Day. 1999. Use of tracer-injection and synopticsampling studies to quantify effects of metal loading from mine drainage. In U.S. Geological Survey Toxic Substances Hydrology Program-Proceedings of the Technical Meeting, Charleston, South Carolina, March 8-12, 1999, Volume 1--Contamination from Hardrock Mining, eds., D.W. Morganwalp and H.T. Buxton, 31-36. U.S. Geological Survey Water Resources Investigations Report 99-4018A.

Leedy, W.P. 1971. Hydrothermal alteration of volcanic rocks in the Red Mountain district of the San Juan Mountains, Colorado. Ph.D. Dissertation, State Univ. of New York, Buffalo.

Lipman, P.W., F.S. Fisher, H.H. Mehnert, C.W. Naeser, R.G. Luedke, and T.A. Steven. 1976. Multiple ages of mid-Tertiary mineralization and alteration in the western San Juan Mountains, Colorado. Econ. Geol. 71: 571-588.

Milhous, R.T. 1999. Aquatic physical habitat and hydrology in abandoned mined land studies. In U.S. Geological Survey Toxic Substances Hydrology Program-Proceedings of the Technical Meeting, Charleston, South Carolina, March 8-12, 1999, Volume 1--Contamination from Hardrock Mining, eds., 
D.W. Morganwalp and H.T. Buxton, 47-53. U.S. Geological Survey Water Resources Investigations Report 99-4018A.

National Institute of Standards and Technology (NIST). 1993a. Certificate of Analysis Standard Reference Material 2704, Buffalo River Sediment.

1993b. Certificate of Analysis Standard Reference Material 2709, San Joaquin Soil.

1993c. Certificate of Analysis Standard Reference Material 2711, Montana Soil.

Pruess, J. 1996. Paleoflood reconstructions within the Animas River Basin upstream from Durango, Colorado. M.S. Thesis: Colorado State Univ., Fort Collins.

Schemel, L.E., B.A. Kimball, and K.E. Bencala. 1999. Colloid formation and transport of aluminum and iron in the Animas River near Silverton, Colorado. In U.S. Geological Survey Toxic Substances Hydrology Program-Proceedings of the Technical Meeting, Charleston, South Carolina, March 8-12, 1999, Volume 1--Contamination from Hardrock Mining, eds., D.W. Morganwalp and H.T. Buxton, 59-62. U.S. Geological Survey Water Resources Investigations Report 99-4018A.

Sloan, R.E., and C.A. Skowronski. 1975. The Rainbow Route, An Illustrated History of the Silverton Railroad, the Northern Silverton Railroad, and the Silverton, Gladstone, \& Northerly Railroad. Denver, Colorado: Sundance Publications Limited.

Smith, K.S., W.H. Ficklin, G.S. Plumlee, and A.L. Meier. 1992. Metal and arsenic partitioning between water and suspended sediment at mine-drainage sites in diverse geologic settings. In Water-Rock Interaction, Proceedings of the $7^{\text {h }}$ International Symposium on Water-Rock Interaction, Park City, Utah, July 1318, 1992, eds. Y.K. Kharaka and A.S. Maast, 443-447. Rotterham: A.A. Balkema.

Tweto, O. 1979. Geologic map of Colorado. U.S. Geological Survey, scale 1:500,000.

Vincent, K.R., S.E. Church, and D.L. Fey. 1999. Geomorphological context of metals-laden sediments in the Animas River flood plain, Colorado. In U.S. Geological Survey Toxic Substances Hydrology Program-Proceedings of the Technical Meeting, Charleston, South Carolina, March, 8-12, 1999, Volume I-Contamination from Hardrock Mining, eds. D.W. Morganwalp and H.T. Buxton., 99-105. U.S. Geological Survey Water-Resources Investigations Report 99-4018A.

U.S. Geological Survey. 1898. Topographic map of the Durango quadrangle, Colorado, scale 1:62,500. 1982. Topographic map of the Silverton quadrangle, Colorado, scale 1:100,000. 


\title{
Distribution of Acid-Generating and Acid-Buffering Minerals in the Animas River Watershed as Determined by AVIRIS Spectroscopy
}

\author{
J. Brad Dalton, Trude V.V. King, Dana J. Bove, Raymond F. Kokaly, Roger N. Clark, J. Sam Vance \\ and Gregg A. Swayze ${ }^{1}$
}

\begin{abstract}
Visible-wavelength and near-infrared multispectral image cubes for the Animas River Watershed from Hermosa, Colorado to the headwaters at Animas Forks, Colorado were acquired on June 18, 1996 using the Jet Propulsion Laboratory's AVIRIS (Airborne Visible and InfraRed Imaging Spectrometer) instrument (Green, et al., 1998). These image cubes have been analyzed using the USGS Tetracorder V3.4 implementation (Clark et al., 1995), an expert system which utilizes a database of more than 300 laboratory spectra of endmember minerals and mineral mixtures to generate maps of mineralogy, vegetation coverage, and other material . distributions. Major iron-bearing, clay, carbonate; and other minerals were identified along with several minerals associated with acid-generating hydrothermal systems including pyrite, jarosite, alunite and goethite. Additionally, distributions of alkaline minerals such as calcite and chlorite indicate a relation between acidbuffering assemblages and stream geochemistry within the watershed.
\end{abstract}

\section{INTRODUCTION}

The Animas River Watershed is the site of a coordinated effort by several federal, state and local agencies to characterize the extent and severity of environmental effects from acid mine water drainage. This water originates both from numerous abandoned mine sites that date back up to a century or more, and from extensive areas of natural altered and mineralized outcrops. The headwaters of the Animas River are within the San Juan and Silverton volcanic calderas, which were responsible for creating large fractures and faults suitable for later mineralization. As part of the Abandoned Mine Lands (AML) Project of the United States Geological Survey (USGS), AVIRIS data were obtained over the San Juan Mountains and Animas Watershed and are being used in conjunction with field geologic mapping, geochemistry and geophysics to determine the relative extent of natural and anthropogenic sources of acid water runoff, and their effect on water quality.

\section{THE AVIRIS DATASET}

The Animas Basin AVIRIS data set is comprised of 14 AVIRIS scenes, approximately $10.5 \mathrm{~km} \times 8 \mathrm{~km}$ apiece, extending from Hermosa, Colorado to the headwaters of the Animas River north of Silverton, near the ghost town of Animas Forks. The 224 spectral channels cover a range from .37 to $2.51 \mu \mathrm{m}$, encompassing visible and near-infrared wavelengths suitable for mapping a wide variety of vegetation and minerals, including but not limited to the hydrothermally altered rocks of relevance to the San Juan Mountains. The 14 scenes are arranged in two overlapping lines parallel to and bounding the Animas river as it flows from its headwaters toward Durango, Colorado. This includes most of the Silverton caldera which is situated within the watershed. The data were acquired under cloud-free late morning conditions on June 18, 1996 in a 17 minute data collection pass. While yearly precipitation is normally quite high in the San Juan Mountains, the resulting thick vegetation still leaves significant outcrops of exposed rock available for analysis; in addition, at the time of acquisition of this dataset, the snowpack was greatly reduced due to melting.

1 U.S. Geological Survey, Mail Stop 973, Box 25046, Denver Federal Center, Denver, Colorado 80225 


\section{REGIONAL GEOLOGY AND MINING ACTIVITY}

The Animas watershed is located in the western part of the mid-late Tertiary age San Juan volcanic field (Lipman et al., 1976; Bove et al., in press). The local geology is largely comprised of lavas and related volcanic rocks associated with the San Juan caldera and the younger Silverton caldera (Steven and Lipman, 1976). Collapse of these calderas created ring fractures which provided conduits for later episodes of intense hydrothermal alteration and mineralization associated with dacitic to rhyolitic intrusion (Casadevall and Ohmoto, 1977; Lipman et al., 1976). More recent geologic activity has been dominated by uplifts during the Neogene (Steven et al., 1995), followed by down-cutting and the formation of the Animas River and its tributaries, with brief episodes of sediment deposition. Gold was discovered in the San Juan Mountains in 1871 and upwards of a thousand mining claims were staked in the upper Animas River above Silverton within the next two decades. The Denver and Rio Grande railroad was extended from Durango to Silverton in 1882 and ore production continued at various levels until 1991 when the Sunnyside Mine directly upstream from Silverton was closed (Church et al., 1997). Remediation of private holdings in the region continues today, and the AML project is partly concemed with evaluating remediation needs of the area, including the thousands of abandoned prospects and mines on both federal and private properties.

\section{MINERAL MAPPING PROCEDURES}

The AVIRIS data for the Animas Watershed were converted to apparent surface reflectance using the radiative transfer methods of ATREM (Gao et al., 1993; Gao et al., 1997) followed by calibration to ground reflectance using a path radiance correction (Clark et al., 1993a). The reflectance data were then analyzed using Tetracorder (Clark et al., 1990, 1991, 1993b, 1995), testing for the presence of over 300 minerals, mineral mixtures, water, vegetation, and other materials of interest. The most significant materials detected-were then assembled into color-coded mineral maps. For this investigation attention focused on the pyrite weathering

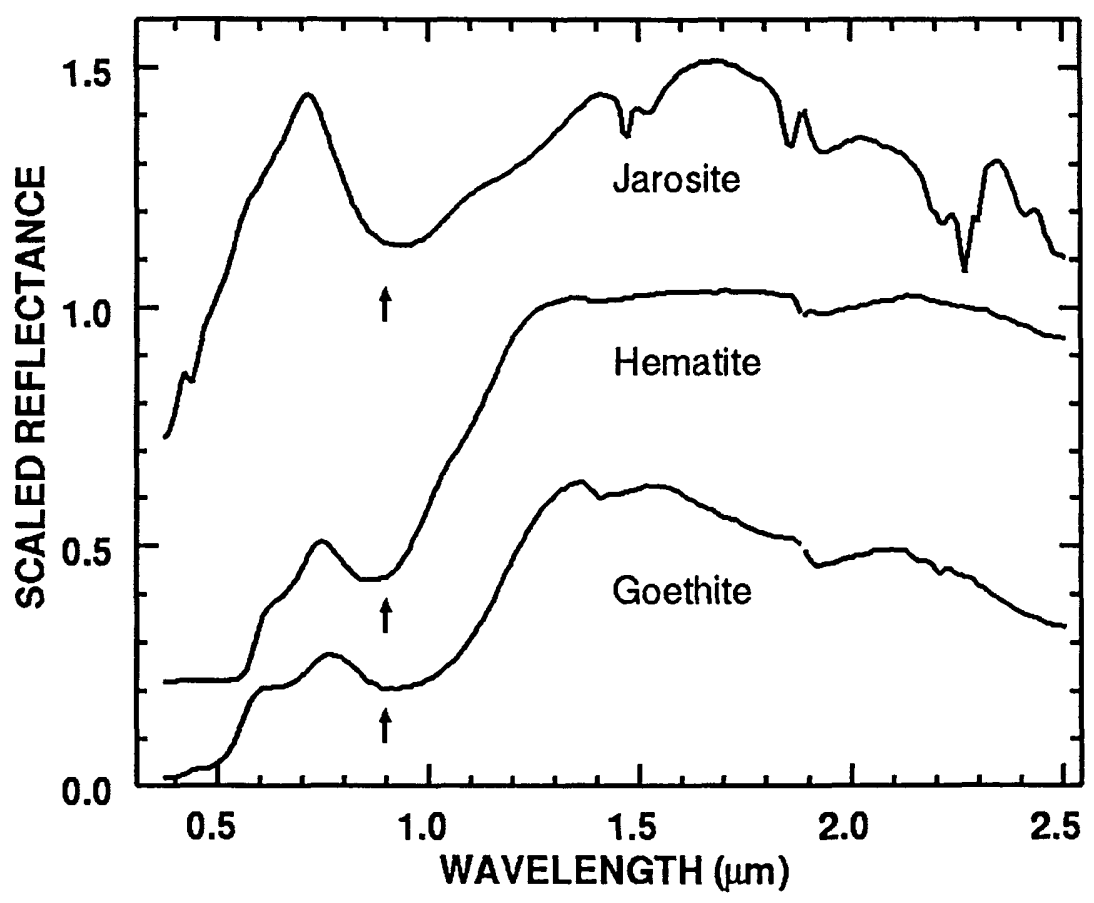

Figure 1 Infrared spectra of primary pyrite weathering products jarosite, goethite, and hematite. Each has a strong Fe absorption centered near $.8 \mu \mathrm{m}$ (arrows.) Due to changes in crystal structure, each mineral exhibits different band positions, strengths, and shapes. Note also that jarosite has a distinctive absorption in the $2.3 \mu \mathrm{m}$ range that is useful for discrimination. 
sequence, wherein pyrite weathers to jarosite, which in turn weathers to goethite, and then hematite. Pyrite oxidation is the primary source of mining-related acidic runoff because sulfuric acid $\left(\mathrm{H}_{2} \mathrm{SO}_{4}\right)$ is a product of this weathering reaction (Swayze et al., 1996). Pyrite itself is difficult to detect directly using AVIRIS because of its extremely low reflectance; however its oxidation products are spectrally bright and have strong $1-\mu \mathrm{m}$ absorptions due to $\mathrm{Fe}^{3+}$ in the matrix. Infrared spectra of the pyrite weathering sequence minerals (Figure 1) show a broad $\mathrm{Fe}^{3+}$ absorption band centered near $0.8 \mu \mathrm{m}$. The exact center of this band (arrows) and its shape are different for jarosite, hematite, and goethite, allowing them to be mapped by the Tetracorder algorithm. Jarosite can be further differentiated by a strong absorption near 2.3 microns. These minerals are abundant in intensely mineralized regions such as in the Red Mountain area (see Bove et al., this volume) north of the Silverton mining district, and elsewhere throughout the watershed. Mine tailings in the San Juan Mountains are typically weathered to jarosite and goethite, and the surface expressions of these minerals readily pinpoint mines and prospects in the AVIRIS scenes. The oxidation process can create distinctive patterns such as bull's eyes of mineral zones on waste rock piles (Swayze et al., 1996). Creeks carrying runoff from tailings piles and mineralized outcrops may have $\mathrm{pH}$ values as low as 1.8 , and this high acidity level enables these streams to carry high concentrations of trace metals (Church et al., 1997) such as zinc, copper, cadmium, arsenic, and lead. Stream beds and banks typically display thick rinds of precipitated iron oxide materials, which also are quite evident in the Tetracorder-processed AVIRIS mineral maps.

For this study, the AVIRIS data were analyzed in two separate groups based on spectral range. The Group 1 minerals were those with strong absorptions in the $1 \mu \mathrm{m}$ wavelength range, such as the pyrite sequence, and other iron-bearing minerals. The Group 2 minerals similarly have their most distinct signatures in the $2 \mu \mathrm{m}$ wavelength range. This group includes most clay minerals, as well as chlorites, epidote, carbonates, and muscovites. Figures 2 and 3 display the preliminary mineral maps for an AVIRIS scene which encompasses the town of Silverton. Although Tetracorder in its current implementation can identify over 300 different materials, only a relative few were considered relevant to this paper. The dominant material in each $17.5 \mathrm{~m}$ AVIRIS pixel was selected by Tetracorder on the basis of a least squares comparison of absorption features in the AVIRIS data to those in the reference library. Each map includes a subset of the minerals considered by Tetracorder; black regions in images correspond to unmapped pixels or materials not under consideration, such as snow cover, minor mineral phases, or the vegetation cover which is prevalent in the Animas Basin. The Silvberton strect grid is expressed by the distribution of mineral signatures near the left center of the images. The Animas River enters the scene from the top right and meanders past the town before exiting on the lower right. Cement Creek and Mineral Creek enter the image from the left; Cement Creek is above the town to the northwest and Mineral Creek below. A typical outcrop of goethite and jarosite was mapped just west of the town and north of Mineral Creek. Although located on a steep slope, the bull's eye pattern (jarosite at the center, goethite surrounding) indicative of pyrite weathering can be clearly distinguished. Such outcrops are major sources of acidic runoff. In the Group 2 map (Figure 3) this location is also characterized by a significant concentration of alunites, another indication of the hydrothermal alteration responsible for local ore formation. In this case, the outcrops are related to abandoned mine adits, but significant natural occurences are also widespread elsewhere in the watershed. In the bottom left of both maps, a series of sedimentary outcrops are highlighted; these outcrops are outside the caldera and are composed primarily of limestones, and are mapped by Tetracorder as calcite.

\section{CALCITE, EPIDOTE AND CHLORITE ASSEMBLAGES}

Recent work has shown that carbonate minerals in the San Juan Mountains may play an important role in the buffering of acidic stream waters, reducing metal concentrations and carrying capacities (Church et al., 1997; Bove et al., this volume). Calcite occurs in the San Juan Mountains both as sedimentary limestone, and as alteration products of primary minerals within volcanic rocks. While calcite within propylitically altered rocks may have a reduced role due to limited availability for buffering reactions (Runnels and Rampe, 1989), the importance of calcite in buffering reactions has been established for limestones (ibid.). Magnesium-bearing chlorites such as clinochlore may also provide some level of buffering of acidic stream reaches, however this has not yet been fully quantified (Desborough et al., 1998; Kwang and Ferguson, 1997). Calcite has been identified and mapped in the Animas River watershed using imaging spectroscopy methods, and its presence in particular stream reaches correlates with increased $\mathrm{pH}$ levels and attendant lowered dissolved trace metal concentrations (Church et al., 1997). Unequivocal identification of calcite in the AVIRIS data is complicated by the spectral absorption bands of epidote and chlorite which overlap the $2.3-\mu \mathrm{m}$ diagnostic calcite absorption. Calcite-epidote-chlorite-bearing lavas are widely distributed in the western San Juan Mountains. 
ANIMAS BASIN - AML 1996 AVIRIS DATA PRELIMINARY ANALYSIS Tetracorder 3.4a8 Run 3 Scene 5-6 Group 1 Minerals

Goethite

Hematite

Nanocrystalline Hematite

Maghemite

\section{Epidote}

Chlorite

Plagioclase Feldspar

Jarosite

Schwertmannite

$\mathrm{Fe}^{3+}$-bearing Minerals

Amorphous and Other Iron Oxides and Hydroxides $\mathrm{Fe}^{2+}$-bearing Minerals

$\mathrm{Fe}^{2+}$-bearing Minerals

$\mathrm{Fe}^{2+}$-bearing Minerals

$\mathrm{Fe}^{2+}$-bearing Minerals with Hematites
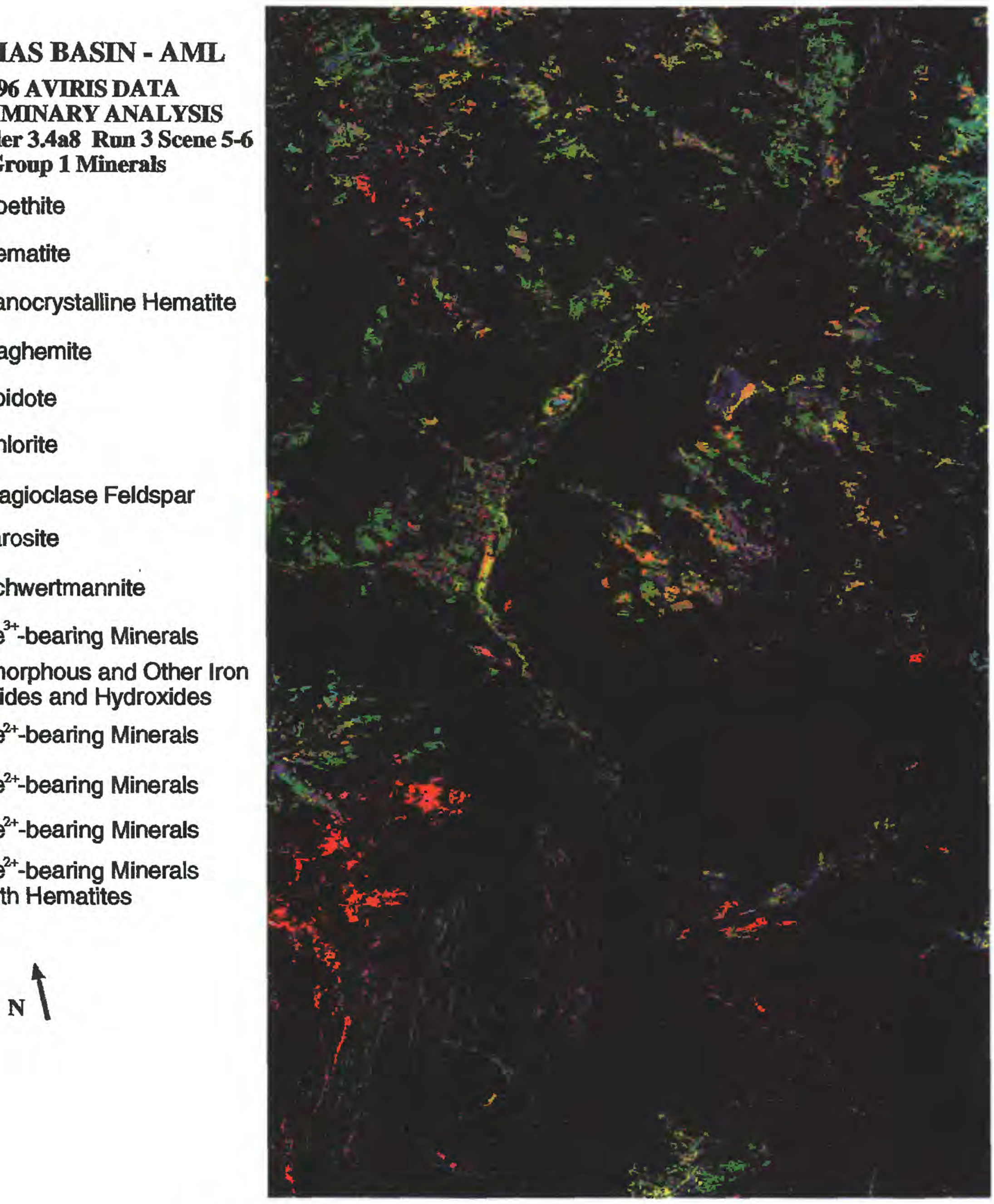

Figure 2 Mineral map of the Silverton area for Group 1 ( $1 \mu \mathrm{m}$ range) minerals as generated by Tetracorder V.3.4. Major alteration and weathering phases are included, as well as five broad classes of iron-bearing minerals. Black regions are unmapped pixels; in the San Juans this is predominantly vegetation though many of the black pixels here are simply not under consideration, such as standing water bodies, snow cover, and minor mineral phases. 
ANIMAS BASIN - AML 1996 AVIRIS

PRELIMIINARY ANALYSIS

Tetracorder 3.4a8 Run 3 Scene 5-6

Group 2 Minerals

Na-Alunites

K-Alunites

Alunite, Kaolinite and Muscovite Mixtures

Muscovite and/or Illite

Muscovite wlth Jarosite

Muscovite with Chlorite and / or Calcite

Calcite with Dolomite

Calcite-Epidote-Chlorite

\section{Chlorites}

Siderite

\section{Epidote}

Halloysite

Na-Montmorillonite

Ca-Montmorillonite

\section{Dickite}

Kaolinite

Kaolinite with Muscovite

Kaolinite with Smectites

Kaolinite with Pyrophyllite

Pyrophyllite
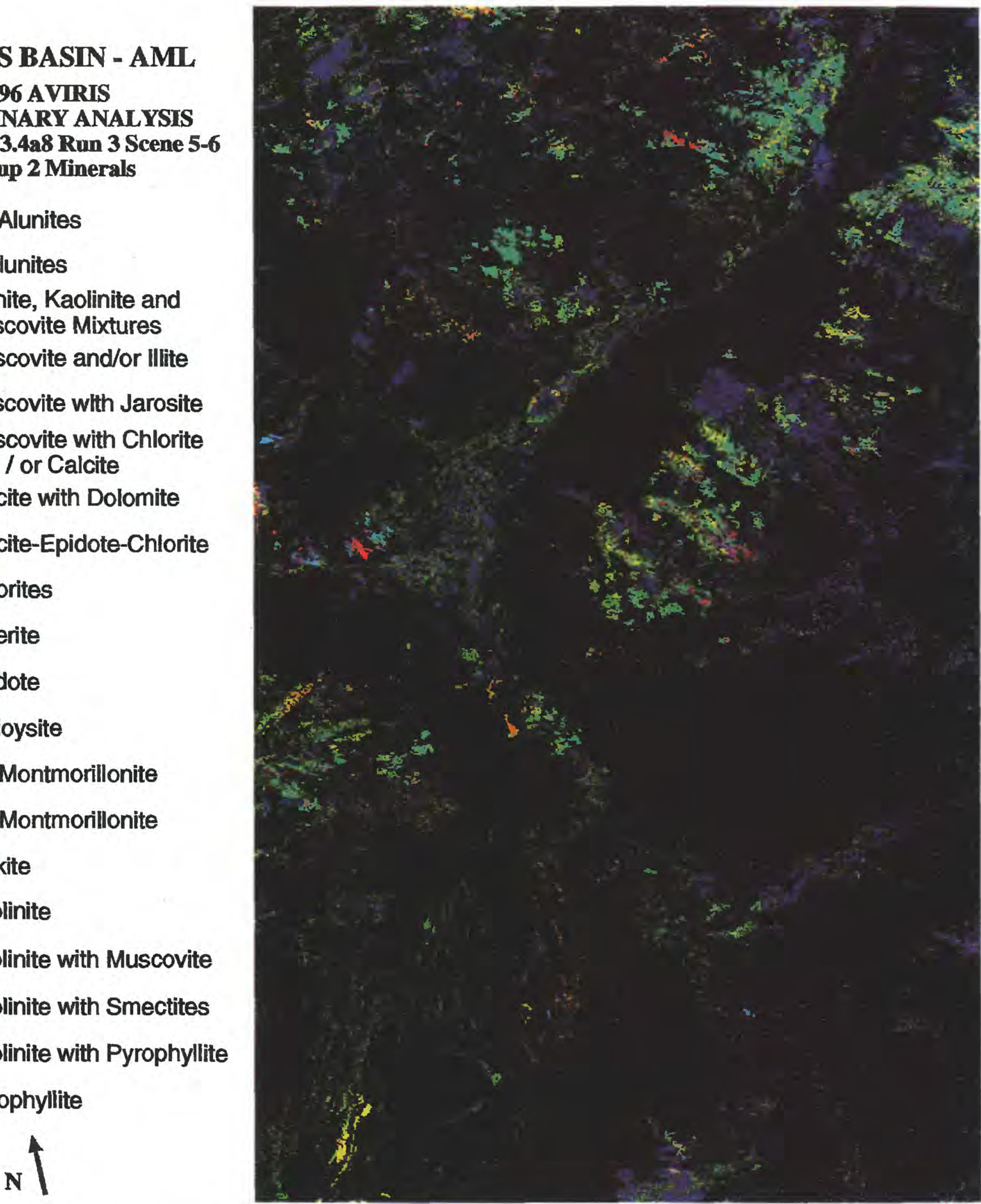

Figure 3 Mineral map of the Sílverton area for Group 2 ( $2 \mu \mathrm{m}$ range) minerals as generated by Tetracorder V3.4. Clays, carbonates, and alunites are of primary interest in this map. Potentially acidbuffering assemblages of calcite, epidote, and chlorite are shown together in one spectral class. 
Sample infrared spectra for calcite, chlorite, and epidote are shown in Figure 4. The diagnostic absorption bands for each of these minerals are centered near $2.3 \mu \mathrm{m}$, and are difficult to distinguish from one another. Based on shapes and band positions, the Tetracorder algorithm can separate the three end members; however when they occur as a fine-grained mixture the individual absorptions combine in nonlinear ways to produce a new absorption spectrum. During the 1998 field season, over 150 samples of calcite-epidote-chlorite lavas were collected in the Animas Basin, and work is now underway to incorporate the complex spectral behavior of these mixtures into the Tetracorder analysis database. The lower spectrum in Figure 4 is of one such sample, a mixture of all three minerals in a finely-grained propylitic lava rock from the Burns formation. Using the full spectral resolution of the AVIRIS instrument, the Tetracorder mapping technique should be able to use such information to define the calcite, epidote and chlorite concentrations in the basin. Areas presently mapped as simply calcite-epidote-chlorite in Figures 3 and 6 will ideally be separated into groups dominated by one of the three minerals, enabling a more accurate assessment of acid-buffering potential. Defining the extent of this buffering capability, however, and improved mapping of these lavas, is an ongoing aspect of our current work.

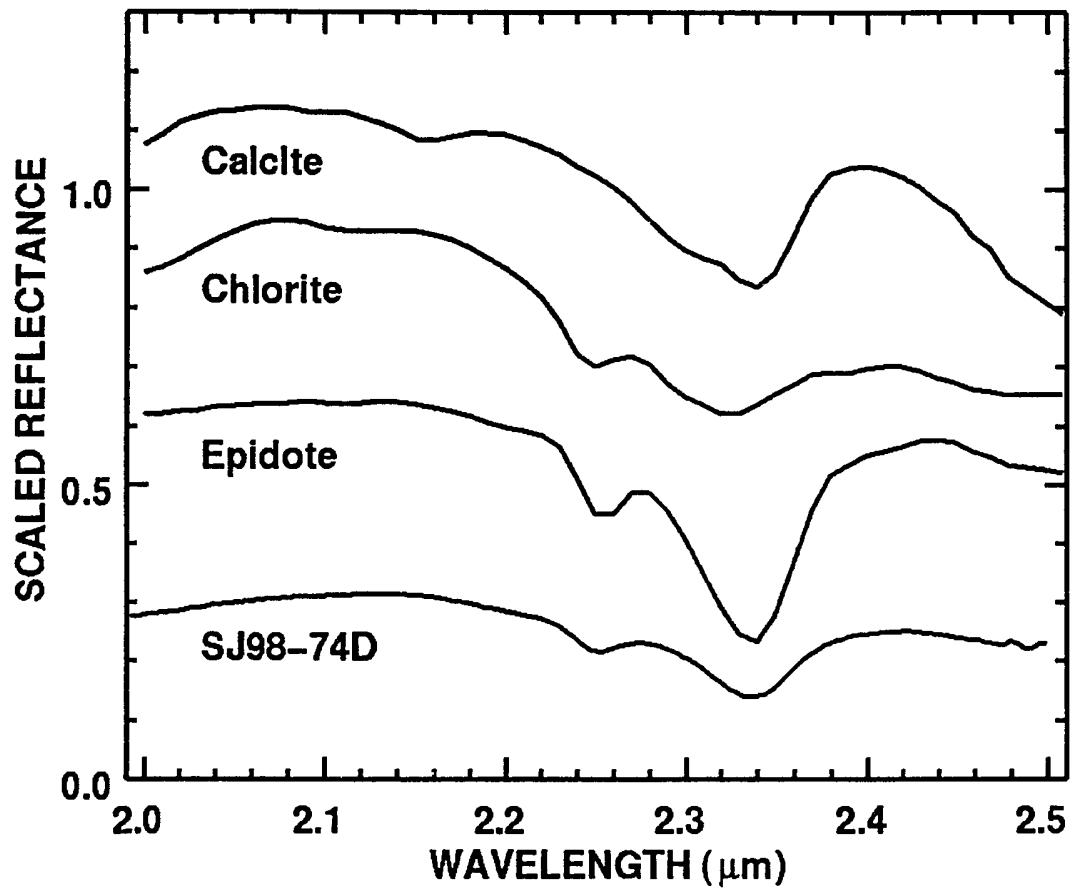

Figure 4 Infrared spectra of calcite, epidote, and chlorite, along with the spectrum of sample SJ9874D, which is a rock comprising a fine-grained mixture of all three in a propylitically altered matrix.

\section{PRELIMINARY AVIRIS MINERAL MAPPING RESULTS}

According to Figure 5 (color section), pyrite-weathering products are abundant in the mountains surrounding the town of Silverton; particularly to the north and west, where hydrothermal activity was more intense. Below the confluence of Cement Creek and the Upper Animas, amorphous iron hydroxides have precipitated from the stream and deposited along the river margins. This is due to an increase in the $\mathrm{pH}$ in the river: the highly acidic water of Cement Creek is diluted by the more neutral waters of the Upper Animas. Although acid-generating minerals are evident throughout the upper portion of the scene, Figure 6 (color section) reveals a much higher concentration of calcite-epidote-chlorite assemblages along the Upper Animas. Aqueous geochemistry has demonstrated (Church et al., 1999) that stream pH is indeed higher along several tributaries to the Upper Animas where these buffering assemblages occur. Along lower stretches of the Animas, water quality continues to improve, especially after the section near Molas Lake (Figure 6, lower left) which contains abundant sedimentary limestone beds, mapped as calcite in Figure 6 and confirmed during the 1998 field season. The absence of buffering mineral assemblages along Mineral and Cement Creeks is one factor 
ANIMAS BASIN - AML 1996 AVIRIS DATA

PRELIMINARY ANALYSIS

Tetracorder 3.4a8

Acid-Generating Minerals

Jarosite

Goethite

Hematite

Nanocrystalline Hematite

Amorphous Fe-Hydroxide

N

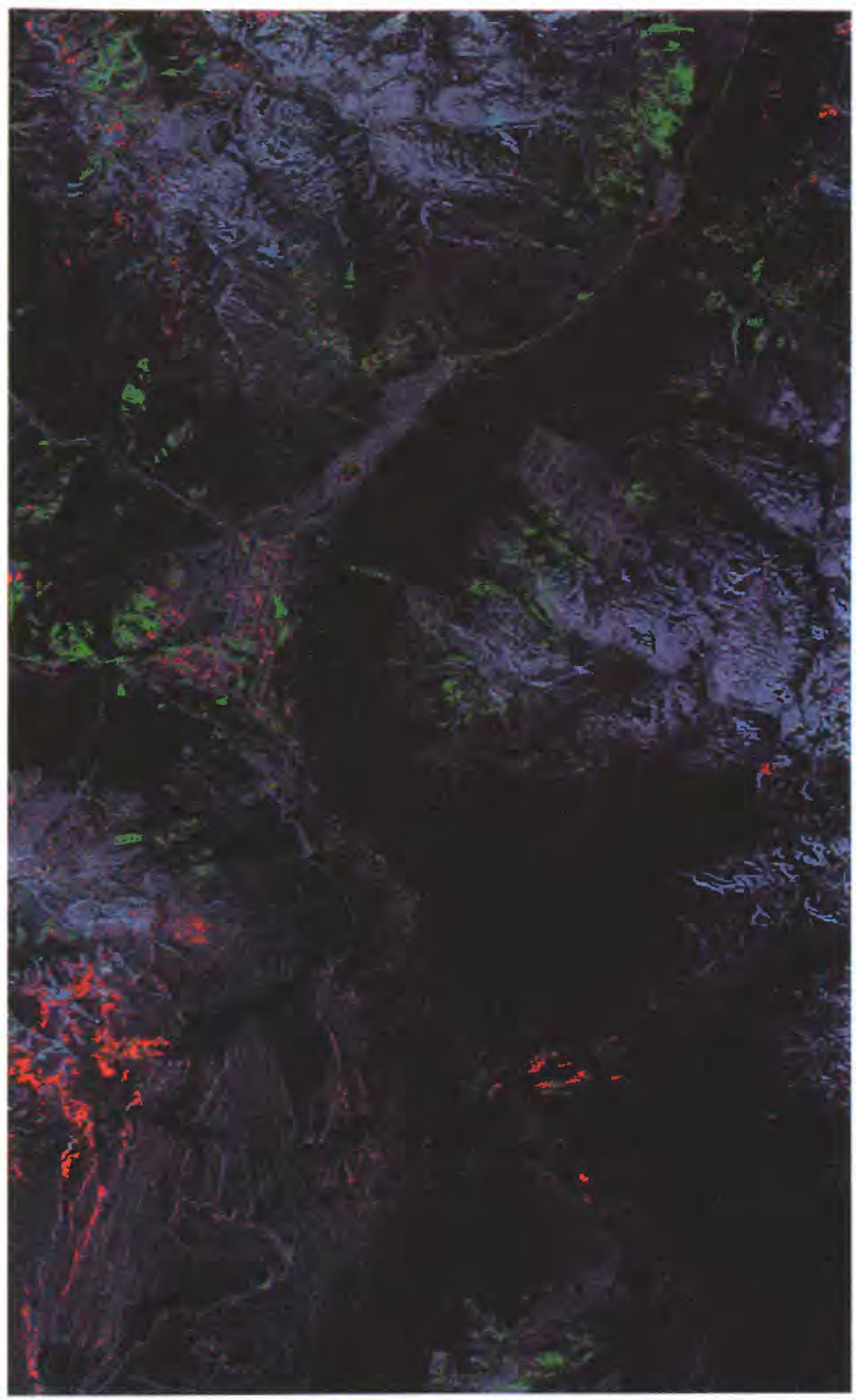

Figure 5 Mineral assemblages indicative of acid runoff superimposed on a single-plane AVIRIS band image to highlight effects of acid-generating minerals on stream quality. Outcrops of pyrite-weathering sequence minerals do not fully correlate with poor water quality. Iron hydroxide precipitates are apparent lining stream edges in this image. 
ANIMAS BASIN - AML 1996 AVIRIS DATA PRELIMINARY ANALYSIS

Tetracorder 3.4a8 Acid-Buffering Minerals

\section{Chlorite}

\section{Epidote}

Calcite-Epidote-Chlorite

Chlorite with Sericite

Calcite

N

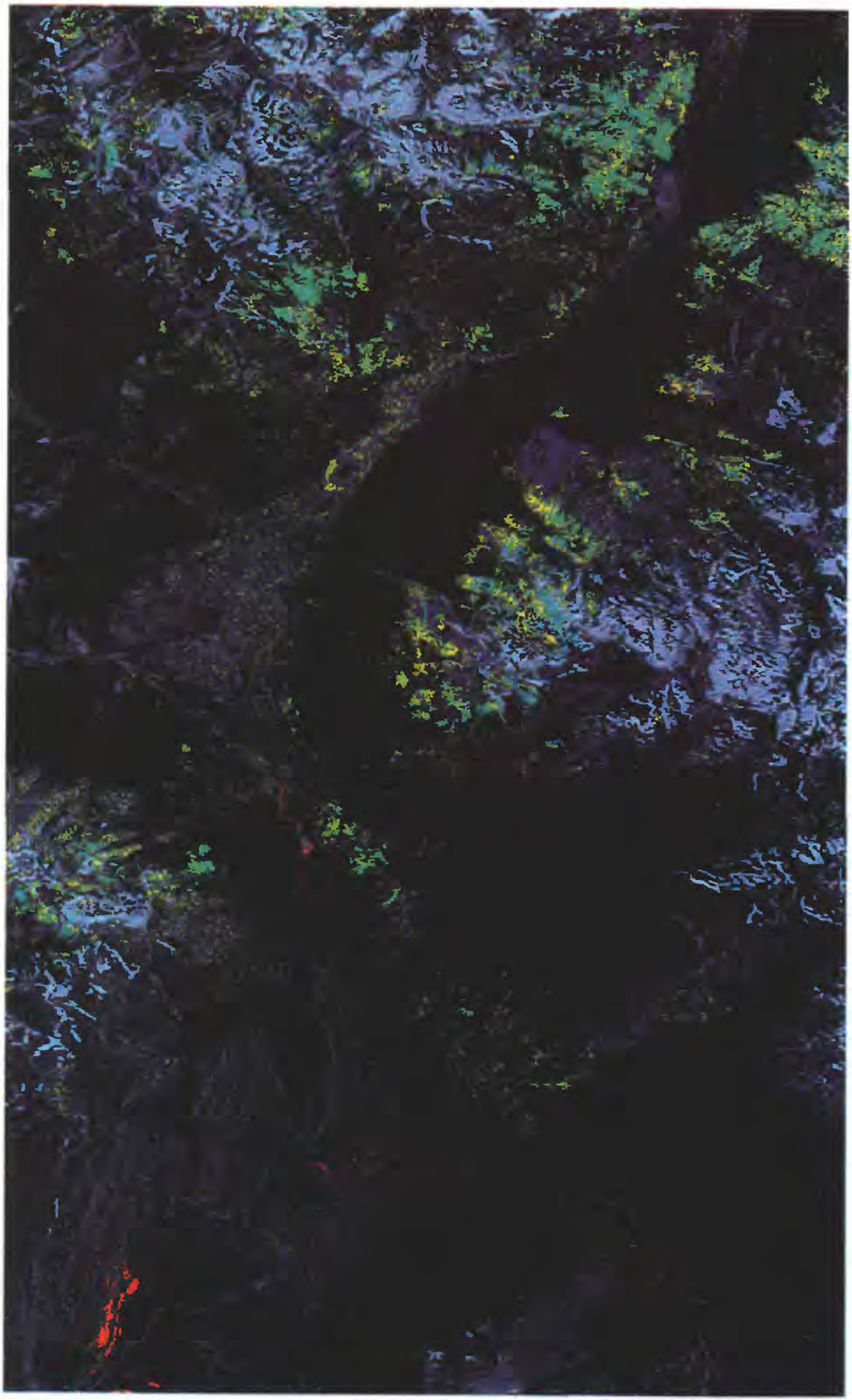

Figure 6 Potentially acid-neutralizing mineral assemblages of calcite, epidote and chlorite snperimposed over a single-plane AVIRIS band image. Improved stream quality in the upper Animas River (top right) is probably due not to the absence of acid-generating minerals, but to the presence of calcite and chlorite in the watershed. Due to spectral overlap, calcite-epidote-chlorite mixtures are not separated in this image. Calcite present as limestone, however, is easily identified in the lower left of the image. 
contributing to their high metal loads. More accurate discrimination between the calcite, epidote and chlorite constituents will play an important role in assessing the natural and artificial factors influencing stream water quality.

\section{CONCLUSION}

Mineral mapping via imaging spectroscopy, as performed using the AVIRIS instrument and USGS Tetracorder algorithm, provides a powerful technique for locating sources of acidic and acid-buffering drainage of either natural or anthropogenic origin. Diagnostic features in absorption spectra of pyrite weathering products provide for accurate identification. Acid-buffering minerals such as calcite and chlorite are also distinguishable in AVIRIS spectra, and work is underway to more accurately characterize them in their host phases and in combination with each other. Field studies have confirmed the presence of all the mineralogies presented in this study, and geochemistry studies within the basin corroborate the findings and indicate a strong link between acid-buffering assemblages and water quality. This approach will be extremely useful to property owners interested in assessing and remediating lands affected by acidic drainage.

This preliminary study, appropriate images, follow-on studies and related research can be found at our web site: http://speclab.cr.usgs.gov.

\section{REFERENCES}

Bove, D.J, M.A. Mast, W.G. Wright, G.P. Meeker, D.B. Yager, and P.C. Verplanck, (in press), Geologic Control on Acidic and Metal-rich Waters in the Southeast Red Mountain Area, Near Silverton, Colorado, Proceedings if the ICARD 2000 Meeting, May 21-24, 2000, Denver Colorado (this volume).

Casadevall, T. and H. Ohmoto, 1977, Sunnyside mine, Eureka mining district, San Juan County, Colorado: Geochemistry of gold and base metal ore deposition in a volcanic environment: Economic Geology, v. 92 , pp. $1285-1320$.

Church, S.E., B.A. Kimball, D.L. Fey, D.A. Ferdener. T.J. Yager, and R.B. Vaughn, 1997, Source, Transport, and Partitioning of metals between Water, Colloids, and Bed Sediments of the Animas River, Colorado, U.S. Geological Survey Open File Report 97-151.

Church, S.E., D.L. Fey, E.M. Brouwers, C.W. Holmes, and R. Blair,1999, Determination of Pre-Mining Geochemical Conditions and Paleoecology in the Animas River Watershed, Colorado, U.S. Geological Survey Open File Report 99-0038.

Clark, R.N., A.J. Gallagher, and G.A. Swayze, 1990, Material Absorption Band Depth Mapping of Imaging Spectrometer Data Using a Complete Band Shape Least-Squares Fit with Library Reference Spectra, Proceedings of the Second Airborne Visible/Infrared Imaging Spectrometer (AVIRIS) Workshop. JPL Publication 90-54, 176-186.

Clark, R.N., G.A. Swayze, A. Gallagher, N. Gorelick, and F. Kruse, 1991, Mapping with Imaging Spectrometer Data Using the Complete Band Shape Least-Squares Algorithm Simultaneously Fit to Multiple Spectral Features from Multiple Materials, Proceedings of the Third Airborne Visible/Infrared Imaging Spectrometer (AVIRIS) Workshop, JPL Publication 91-28, 2-3.

Clark, R.N., Swayze, G.A., Heidebrecht, K.B., Goetz, A.F.H., and R.O. Green, 1993a, Comparison of Methods for Calibrating AVIRIS Data to Ground Reflectance, Summaries of the $4^{\text {th }}$ Annual JPL Airborme Geosciences Workshop, Volume 1: AVIRIS Workshop, JPL Publication 93-26, pp. 31-34.

Clark, R.N., G.A. Swayze, and A. Gallagher, 1993b, Mapping Minerals with Imaging Spectroscopy, U.S. Geological Survey, Office of Mineral Resources Bulletin 2039, pp. 141-150.

Clark, R.N. and G.A. Swayze, 1995, Mapping Minerals, Amorphous Materials, Environmental Materials, Vegetation, Water, Ice and Snow, and Other Materials: The USGS Tricorder Algorithm. Summaries of the Fifh Annual JPL Airborne Earth Science Workshop, January 23- 26,, Vol. 1: AVIRIS Workshop, R.O. Green, Ed., JPL Publication 95-1, p. 39-40.

Desborough, G.A., P.H. Briggs, and N. Mazza,1998, Chemical and Mineralogical Characteristics and Acid-Neutralizing Potential of Fresh and Altered Rocks and Soils of the Boulder River Headwaters in Basin and Cataract Creeks of Northern Jefferson County, Montana, U.S. Geological Survey Open File Report 98-40. 
Gao, B.C., K.B. Heidebrecht, and A.F.H. Goetz, 1993, Derivation of Scaled Surface Reflectances from AVIRIS Data, Remote Sensing of Environment, v. 11, 99. 1775-1795.

Gao, B.C., K.B. Heidebrecht, and A.F.H. Goetz, 1997, Atmosphere Removal Program (ATREM) Version 3.0 User's Guide, Center for the Study of Earth from Space, University of Colorado at Boulder.

Green, R.O., D.A. Roberts, and J.E. Conel, Characterization and Compensation of the Atmosphere for the Inversion of AVIRIS Calibrated Radiance to Apparent Surface Reflectance. Summaries of the Sixth Annual JPL Airborne Earth Science Workshop, March 4-8, 1996, JPL Publication 96-4, Vol. 1, AVIRIS Workshop, pp. 135-146.

Green, R.O., M.L. Eastwood,C.M. Sarture T.G., Chrien., M. Aronsson, B.J. Chippendale, J.A. Faust, B.E. Pavri, C.J. Chouit, M. Solis, M.R. Olah, and O. Williams, 1998, Imaging Spectroscopy and the Airborne Visible Infrared Imaging Spectrometer (AVIRIS), Remote Sens Environ, v.65;(3), pp. 227-248.

Kwang, Y.T.J., and K.D. Ferguson, 1997, Mineralogical Changes During NP Determinations and their Implications, Proceedings of the Fourth International Conference on Acid Rock Drainage, Vancouver, B >C., May 31-June 6 1997, pp. 435-447.

Lipman, P.W., H.H. Mehnert, C.W. Naeser, R.G. Luedke, and T.A. Steven, 1976, Multiple Ages of midTertiary mineralization and alteration in the Western San Juan Mountains, Colorado, Economic Geology, v. 71, pp. 571-588.

Runnells, D.D., and J.J. Rampe, 1989, Natural Clean-up of a Stream Contaminated by Mine and Mill Wastes: A Reaction Analogous to Liming in Water Treatment, Proceedings of the $6^{\text {th }}$ International Symposium on Water-Rock Interaction, Malvern, 3-8 August 1989, Ed. D.L. Miles, pp. 597-598.

Steven, T.A., K. Hon, and M.A. Lanphere, 1995, Neogene Geomorphic Evolution of the Central San Juan Mountains Near Creede, Colorado, U.S. Geological Survey Map I-2504, Denver Colorado.

Steven, T.A., and P.W. Lipman, 1976, Calderas of the San Juan Volcanic Field, Southwestern Colorado: U.S. Geological Survey Professional Paper 958.

Swayze, G.A, R.N. Clark, R.M. Pearson, and K.E. Livo, 1996, Mapping Acid-Generating Minerals at the California Gulch Superfund Site in Leadville, Colorado using Imaging Spectroscopy. Summaries of the 6th Annual JPL Airborne Earth Science Workshop, JPL Publication.

Swayze, G.A., R.N. Clark, K.S. Smith, P.L. Hageman, S.J. Sutley, R.M. Pearson, G.S. Rust, P.H. Briggs, A.L. Meier, M.J. Singelton, and S. Roth, 1997, Using Imaging Spectroscopy to Cost-Effectively Locate Acid-Generating Minerals at Mine Sites: An Example From the California Gulch Superfund Site In Leadville, Colorado. Geological Society of America Abstracts with Programs, October 20-23, 1997 , v. 29 , no. 6 , pp. A-322. 


\title{
Comparison of Two Leach Procedures Applied to Metal-Mining Related Wastes in Colorado and Montana and a Relative Ranking Method for Mine Wastes
}

\author{
David L. Fey, George A. Desborough, and Stanley E. Church
}

\begin{abstract}
About 100 mine-waste dumps from past metal exploration and mining in Colorado and Montana were sampled using surficial-sampling methods for laboratory studies of the minus-2-mm fraction. In the laboratory, the composite samples were split into $100 \mathrm{~g}$ samples that were leached to assess their acidgeneration potential and associated release of potentially toxic metals that may degrade water-quality in the headwaters of the Animas River watershed in Colorado and the Boulder River watershed in Montana. Two leach methods were studied: a passive leach using de-ionized water, and a more aggressive leach following the EPA-1312 method.

The resulting $\mathrm{pH}$ values of the leachates using both methods are comparable. The concentrations of sulfate and several, but not all, dissolved or water-soluble metals are higher in the EPA-1312 leachates than in the passive leachates; however, the overall trends of the data are very similar. The passive leach method is less labor intensive and may be more representative of the natural weathering process occurring on the mine-waste dumps, simulating the natural precipitation and snowmeit.

Three chemical characteristics of mine wastes studied here provide a relative ranking of mine-waste dumps for the purpose of determining priority for removal or remediation. These characteristics are: net acid production (NAP), sum of dissolved toxic metals ( $\mathrm{EAs}+\mathrm{Cd}+\mathrm{Cu}+\mathrm{Pb}+\mathrm{Zn}$ ), and dissolved iron in leachates. Ranking can be done evaluating plots of NAP versus the sum of dissolved toxic metals, and NAP versus dissolved iron. These two plots serve as a basis for relative ranking of polymetallic-vein and acid-sulfate mine . wastes studied. This ranking scheme may apply to mine wastes from production of other deposit types in other watersheds.

\section{INTRODUCTION}

The objective of this study was to determine the bulk metal concentrations, acid-generating capacities, and water-soluble or dissolved metal concentrations for 106 samples of inactive metal-mine-waste dumps in Colorado and Montana. These data should aid in the assessment of discrete point sources causing waterquality degradation and potential remediation strategies for mine wastes.

This study is part of the Abandoned Mine Lands (AML) Initiative described by Buxton et al. (1997). The AML initiative develops multidisciplinary scientific methods to improve the understanding of potentially degrading effects of metal-mine wastes and associated mine drainage waters on riparian habitat and aquatic wildlife. Mine-waste dumps were sampled in two AML pilot study areas, the Animas River watershed in southwestern Colorado and the Boulder River watershed in western Montana. The wastes sampled in Colorado are located in the upper Animas basin near Silverton, in San Juan County. This area receives about $100-125 \mathrm{~cm}$ (40-50 in) of precipitation annually, most of it as snowfall. Elevations range from about 3,100 to $4,600 \mathrm{~m}(9,200-13,800 \mathrm{ft})$ above mean sea level (Buxton et al., 1997). The study area in western Montana is about $30 \mathrm{~km}$ (20 miles) south-southwest of Helena. It includes several tributary drainages in the headwaters of the Boulder River, near Boulder, in northern Jefferson County. This area receives about 35-75 cm (14-30 in) of precipitation annually, also mostly as snowfall. Elevations range from about $1,600-3,000 \mathrm{~m}$
\end{abstract}

U.S. Geological Survey, Federal Center, Denver, CO 80225-0046 
$(4,900-8,800 \mathrm{ft})$ above mean sea level (Buxton et al., 1997). The primary fish in both areas is trout. The mean pH for precipitation in 1997 for the Colorado study area was 4.9; the mean pH for precipitation in 1997 in the Montana study area was 5.1. (National Atmospheric Deposition Program (NRSP-3)/National Trends Network, 1999).

Desborough and Fey (1997) reported preliminary mineralogical, acid-generating, and leaching characteristics for mine wastes in the Boulder, Montana study area. They ranked mine wastes acoording to their acid-generating potential, soluble toxic-metal concentrations, and size. These wastes are from polymetallic-vein deposits which typically contain pyrite, arsenopyrite, galena, and sphalerite as the dominant sulfide minerals.

Approximately $90 \%$ of the Animas basin mine wastes are from polymetallic-vein deposits containing pyrite, galena, and sphalerite as the dominant primary sulfide minerals. The other Animas mine wastes are from pyrite-enargite-chalcocite-covellite ores hosted in acid sulfate-altered rocks and have higher copper and arsenic concentrations than the polymetallic vein mine wastes (D.L. Fey and J.T. Nash, U.S. Geological Survey, unpublished data). Nash (1999a, 1999b) described some of the characteristics of many mine-waste dumps in the Animas River study area. He prioritized remediation of these mine wastes in terms of the pH of passive leach solutions, soluble toxic-metal concentrations, size, and other factors including proximity to roads and streams, and presence of water running through or across the wastes.

The present study focuses on chemical characteristics that may be useful for ranking mine wastes with respect to long-term acid-generation potential, water-soluble acidity, and toxic-metal mobility. As these data could be used to assess whether the mine-waste dumps should be removed, rigorous field sampling and laboratory methods were applied in this study.

\section{SAMPLE COLLECTION AND PREPARATION}

Samples were taken from the waste dumps of 19 inactive mines in the Boulder River study area and from 87 inactive mines in the upper Animas River study area. Material was collected from $\mathbf{3 0}$ or more cells across the top and sides of the dump to a depth of about $5 \mathrm{~cm}$ using four to six randomly selected $50-80 \mathrm{~g}$ scoops. This material was passed through a $2 \mathrm{~mm}$ screen to remove coarse material because the minus- $2 \mathrm{~mm}$ fraction was deemed to be the most reactive to water in short-term exposures. The resulting composite sample typically contained 1 to $2 \mathrm{~kg}$ of mine-waste dump material (Desborough and Fey, 1997, Nash, 1999a, 1999b).

In the laboratory, samples were dried at $40^{\circ} \mathrm{C}$, split using a Jones splitter, and recombined several times to achieve thorough mixing. Splits from the homogenized material were made for: 1) ICP-AES total element analyses, 2) EPA-1312 leach test, 3) passive leach test, and 4) net acid production (NAP). Splits for the passive leach and the EPA-1312 leach did not require further preparation; splits for total-element analyses and for NAP measurements were ground in a vertical pulverizer with ceramic plates to minus-200-mesh (75 microns).

\section{ANALYTTCAL METHODS}

\section{Total Element Digestion Method}

A 0.2 gram portion of minus-200-mesh material was subjected to a mixed-acid total digestion using $\mathrm{HCl}$, $\mathrm{HNO}_{3}, \mathrm{HClO}_{4}$ and $\mathrm{HF}$ acids (Briggs, 1996). The resulting solution was analyzed for 40 elements, using inductively coupled-plasma atomic emission spectroscopy (ICP-AES). This digestion is very effective in dissolving sulfides and most silicates and oxides.

\section{EPA-1312 Leach Method (Synthetic Precipitation Leach Procedure-SPLP)}

A 100 -gram sample of mine waste was placed in a $2.3 \mathrm{~L}$ polyethylene bottle. Two liters of an extract solution were added, resulting in a 1:20 sample/extract ratio, with $300 \propto$ of head space. The SPLP method mandates that an extract solution with pH of $\mathbf{4 . 2}$ be used on soils from east of the Mississippi River, and a solution with $\mathrm{pH}$ of 5.0 be used on soils from west of the Mississippi River, and the more acidic pH 4.2 solution be used on mine-waste material. Since all of our samples were mine wastes, we used the pH 4.2 extract solution. The extract solution was made from de-ionized water acidified with a $1 \%$ solution of $60 / 40 \mathrm{H}_{2} \mathrm{SO}_{4} / \mathrm{HNO}_{3}$. The capped bottles were placed on an end-over-end rotating agitator at $30 \mathrm{rpm}$ for 18 hours. The leachates were then pressure-filtered through a $142 \mathrm{~mm}$ diameter-0.7 micron glass-fiber filter. (U.S.-EPA, 1986). A $100 \mathrm{ml}$ aliquot of filtered solution was acidified with 6 drops of ultra-pure $\mathrm{HNO}_{3}$ for analysis by ICP-AES for 24 elements (Briggs and Fey, 1996) and for sulfate by ICP as sulfur. Conductivity and pH were determined on the bulk filtered leachate. 
Passive Leach Method

A 100-gram sample was exposed to $2 \mathrm{~L}$ of laboratory de-ionized water $(\mathrm{pH}$ of $5.0 \pm 0.2$ ) in an open $4 \mathrm{~L}$ beaker. Samples were left at rest for one hour, and then gently stirred for five seconds to prevent stratification of the leachate. The $\mathrm{pH}$ of the leachate was measured after 24 hours and then a $60 \mathrm{ml}$ sample of the leachate was filtered through a Gelman 0.45 micron filter using a disposable $60 \mathrm{ml}$ syringe (Desborough and Fey, 1997), acidified with 6 drops of ultra-pure $\mathrm{HNO}_{3}$, and refrigerated prior to analysis by inductively coupled plasmamass spectroscopy (ICP-MS) by a commercial laboratory.

\section{Net Acid Production Method}

A 1.0 gram sample of pulverized, minus-200-mesh material was digested with $30 \%$ hydrogen peroxide to oxidize pyrite and arsenopyrite, thereby producing sulfuric acid (Lapakko and Lawrence, 1993). This acidic solution reacted with the bulk of the mine-waste sample, released additional acidity from water-soluble iron sulfates, and reacted with minerals that consume acid, such as carbonates and some non-carbonate minerals such as biotite, chlorite and epidote. The solutions were heated for 1 hour, coled, and filtered. The acidic filtrate was then titrated to a $\mathrm{pH}$ of 7 with $0.1 \mathrm{M} \mathrm{NaOH}$. A calculated net acid production (NAP) is expressed in terms of $\mathrm{kg}$-equivalent $\mathrm{CaCO}_{3}$ per metric ton of mine waste. This NAP is meant to represent the long term or total potential of a mine waste to produce acid over an unspecified time period of weathering of the minewaste dump.

\section{EPA-1312 LEACH COMPARED TO PASSIVE LEACH RESULTS}

We applied the EPA-1312 leach method and the passive leach method to separate splits of all of the minewaste samples. The purpose of using the EPA-1312 method was to assess short-term acid release and solubility of toxic metals, and to compare those attributes with the conductivity, total acidity, and soluble sulfate. The purpose of using the passive leach was to evaluate the effectiveness of this less labor-intensive method compared to the EPA-1312 method. We suggest that the passive leach more closely simulates processes occurring at the surface of waste piles exposed to rainwater and snowmelt runoff.

The final pH values in leachates from both methods show remarkable agreement (Fig. 1). The data points that plot above the 1:1 line are thought to be due to liberation of buffering minerals (e.g. calcite) in the tumbling process of the EPA-1312 method. Four of the mine-waste samples that plot above the 1:1 line have $\mathrm{pH}$ values $>6.5$ and contain calcite or dolomite as detected by $\mathrm{X}$-ray diffraction (Fig. 1).

The main difference between the two leach methods is the vigorous and continuous mixing of leachate with sample in the EPA-1312 method that results in higher concentrations of weak-acid-soluble metals. The tumbling action of the EPA-1312 method probably results in a reduction in grain size of the waste material.

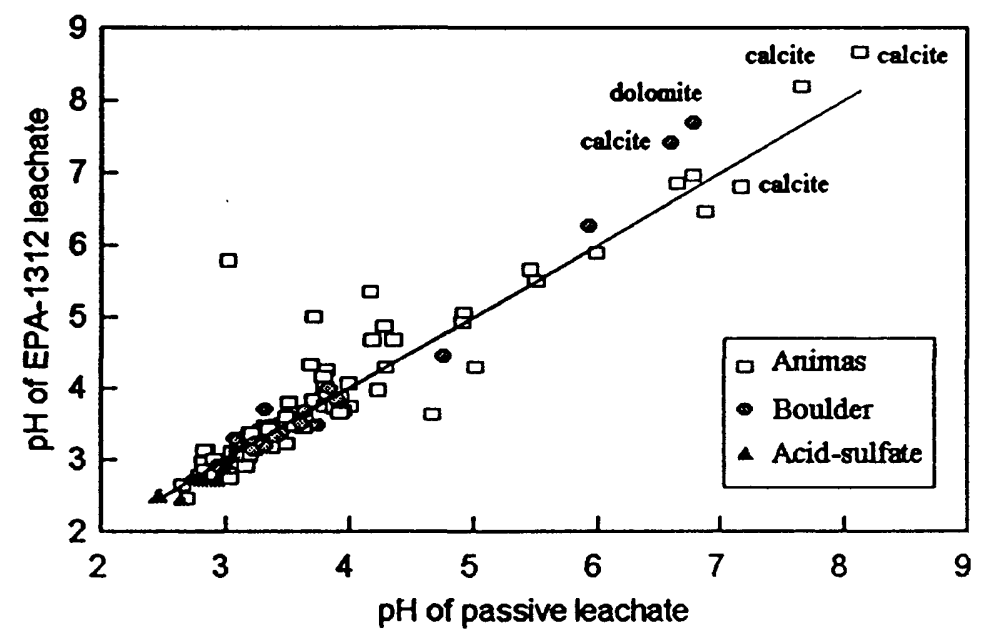

Figure 1 Comparison of the measured pH of the leachates from the EPA-1312 and passive leach methods. The diagonal line represents the ideal 1:1 correspondence. Mineral deposit types from the Animas and Boulder watershed are shown using different symbols. 


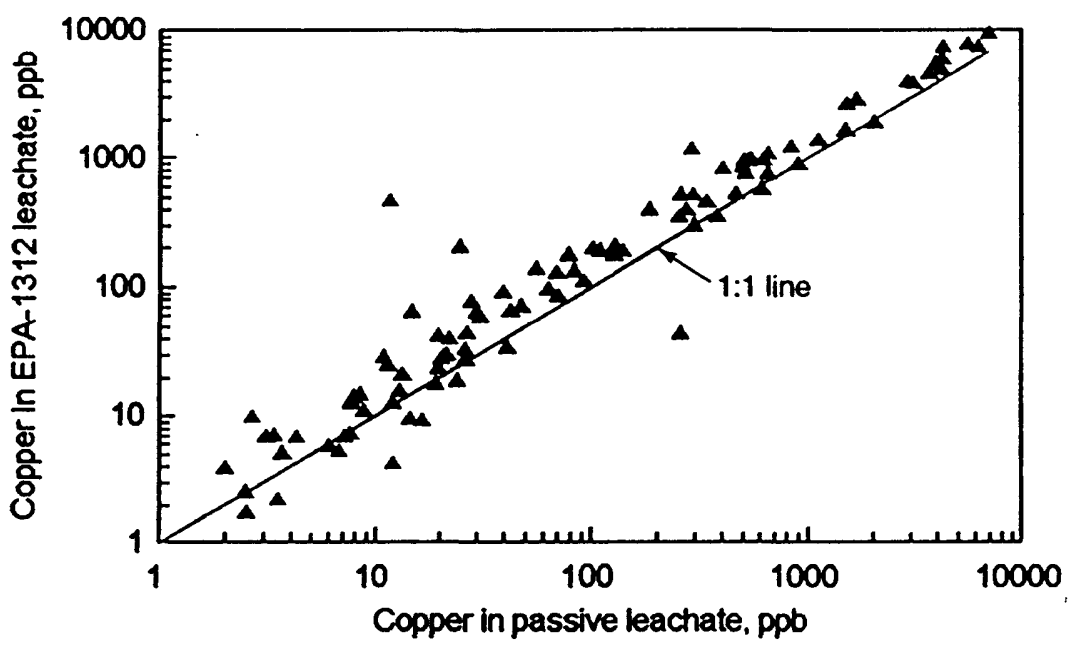

Figure 2 Comparison of the concentration of copper (ppb) in leachates from the EPA-1312 and passive leach methods. The EPA-1312 leach is more efiective in extracting weak-acid-soluble copper from the mine wastes. The diagonal line represents the ideal 1:1 correspondence.

Leinz et al. (this volume) showed that samples with smaller grain sizes generally produce leachates with higher dissolved metal concentrations. Comparison between the methods for copper (Fig. 2) shows good correlation of results from both leach procedures, with a distinct bias towards higher concentrations in the EPA-1312 leachate. Other elements such as calcium, manganese; magnesium, strontium, and aluminum show a similar bias towards higher concentrations in the EPA-1312 leachates. Environmentally important elements such as cadmium and zinc also show good correlations between data from the two method, again with higher concentrations extracted by the EPA-1312 method. Sulfate is the dominant anion in the leachates. Sulfate concentrations were analyzed by ICP-AES on a subset of mine-waste samples prepared by both leach procedures; results from the EPA-1312 leachates showed higher sulfate values. The higher sulfate values in the EPA-1312 leachates are not a result of sulfate contributed from the extract solution (made with approximately five $\mathrm{ml}$ of one-percent $60 / 40 \mathrm{H}_{2} \mathrm{SO}_{4} / \mathrm{HNO}_{3}$ per 20 liters), as determined by multiple analyses of procedure blanks, which contained only 2 ppm sulfate.

Several important elements, including iron, lead, and possibly arsenic, do not exhibit these simple relationships. Figure 3 shows the spread of the iron data from the passive leachate and the EPA-1312 leachate.

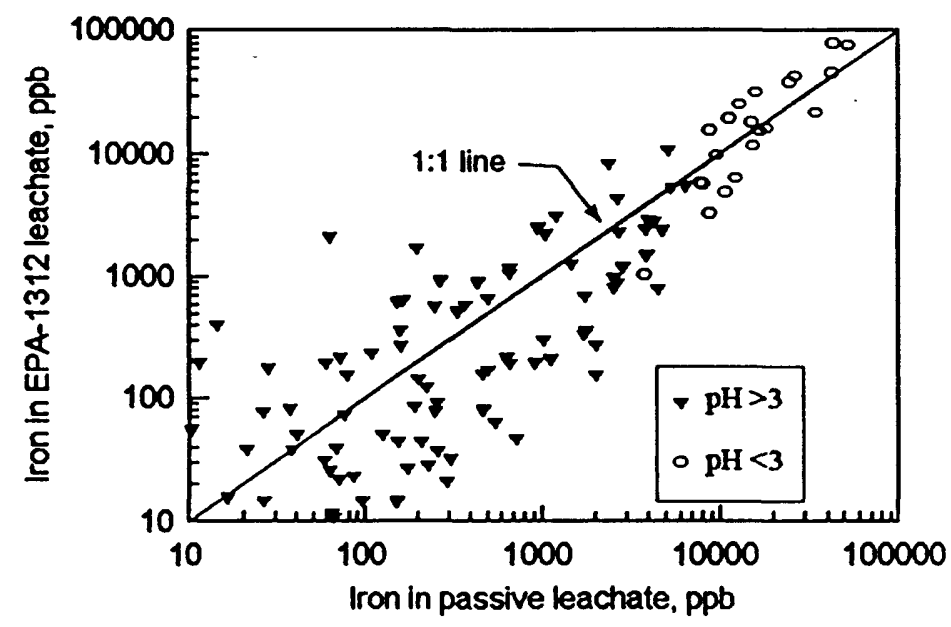

Figure 3 Comparison of the concentration of iron (ppb) in leachates from the EPA-1312 and passive leach methods. The iron concentrations in leachates from both methods show a reduction in the scatter of the data in solutions where the $\mathrm{pH}$ is $<3$. 
This same general trend is seen for lead and possibly arsenic, although the arsenic data are truncated by the uncertainty of the analytical methods at low concentrations. There appears to be no systematic bias in the data favoring dissolved iron in the EPA-1312 leachates. The scatter about the 1:1 correlation line on the iron diagram (Fig. 3) is much greater than that for copper (Fig. 2).

One noticeable feature of the plot of the dissolved iron data is that there is much better agreement between data from the two leach methods at higher iron concentrations as shown by the convergence of the analytical data at higher values and lower $\mathrm{pH}$. A possible explanation for the wide scatter at lower concentrations and higher $\mathrm{pH}$ involves the precipitation of iron colloids from some leach solutions, and the methods of filtration. At the end of the leach period using the passive leach method, we observed a red-orange precipitate coating the top surface of some leached mine-waste samples. The color of these samples was originally gray. Above a pH of 3.5, iron begins to precipitate and form colloids (Smith et al., 1993) We interpret that this red-orange precipitate consists of settled iron colloids, and suspect that colloid formation also occurred in the EPA-1312 leachates, where the fine precipitate would not be observed because the samples were continuously mixed during extraction. The EPA-1312 leachates were bulk-filtered in a pressurized stainless-steel unit using a $142 \mathrm{~mm}$-diameter filter with nominal pore size of 0.7 microns, whereas the passive leach solutions were filtered through a syringe-mounted 0.45 micron Gelman filter. The coarser filter used for the EPA-1312 leachates would seem to allow more colloidal iron to pass through the filter into the leachate. However, since the entire sample including residual sludge is filtered, the filter disc can quickly be packed with very fine sediment (clay sized) to a thickness of $3 \mathrm{~mm}$ or more, and thus the effective pore size can be reduced to less than the stated 0.7 microns. Depending on the particle size distribution of individual samples, this effective reduction of pore size would be variable. The solutions from the passive leach were collected with a syringe directly from the solution, without disturbing the sediment, and so the passive leachate filters were not subject to packing. For some samples, the EPA-1312 method may be removing more smaller suspended material than the passive method. Thus, an unknown amount of iron may be sequestered in a colloidal phase, which is subject to removal by filtration. At pH $>3.5$, lead and arsenic would be sorbed onto these iron colloids (Smith et al., 1993) and also be removed, which would explain the wide dispersion of the results for these two metals as well. Samples of non-crystalline iron-rich orange precipitates were collected from Cement Creek near Silverton, Colorado. These precipitates, collected from water with a pH of 5.4, contained 500 ppm (parts per million) copper, 540 ppm zinc, and 930 ppm lead (G.A. Desborough, U.S. Geological Survey, unpublished data). How much of the variation in the data sets is due to the differences in filter size, filter packing, and colloid formation was not determined; the scatter is likely due to a combination of several factors.

Formation of iron colloids and sequestration of metals in these leaching studies reflects an important process that oocurs in streams receiving metal-rich mine-waste drainage. Church et al. (1997) observed that when the $\mathrm{pH}$ of drainage waters is raised either by dilution or mixing, copper and zinc can be sorbed onto colloids and transported large distances from source areas. The sorbent colloids can be incorporated into the bed sediments, where they are bio-available to benthic invertebrates that comprise the food chain for fish. It is important to note that analysis of laboratory leachates with pH's greater than 3.5 may not reflect the partitioning of metals between the dissolved phase and the colloidal phase. In the field, the colloidal phase is easily transported from the mine-waste site by surface runoff and can contribute to the degradation of overall habitability of a stream reach.

The concentrations of dissolved metals in filtered leachates may nevertheless be an important parameter, and whereas the concentrations of dissolved metals differ between the two leach methods, we conclude that the simple passive leach method provides reliable, cost-effective data on the release of soluble metals and acidity stored in water-soluble salts from mine-waste materials. Several studies have made use of the passive leach to characterize mine-waste-dump and mill-tailings material in terms of their ability to release watersoluble metals and to lower the pH of waters (Desborough and Fey, 1997; Nash 1999a, 1999b).

\section{EPA-1312 LEACH RESULTS: CONDUCTIVITY, PH, SULFATE, TOTAL ACIDITY, AND DISSOLVED METALS}

When pyritic mine-wastes are exposed to air and water in the environment, acid is formed by the oxidation of pyrite according to several reactions (Alpers et al., 1994). The acid generated will attack other sulfide minerals, releasing potentially toxic metals such as zinc, cadmium, copper, arsenic, and lead. Calcite will be dissolved, neutralizing an equivalent amount of acid. Partial dissolution of silicate minerals, especially biotite, chlorite and epidote, aiso serves to neutralize acid. The leaching of mine wastes by the EPA-1312 leach 


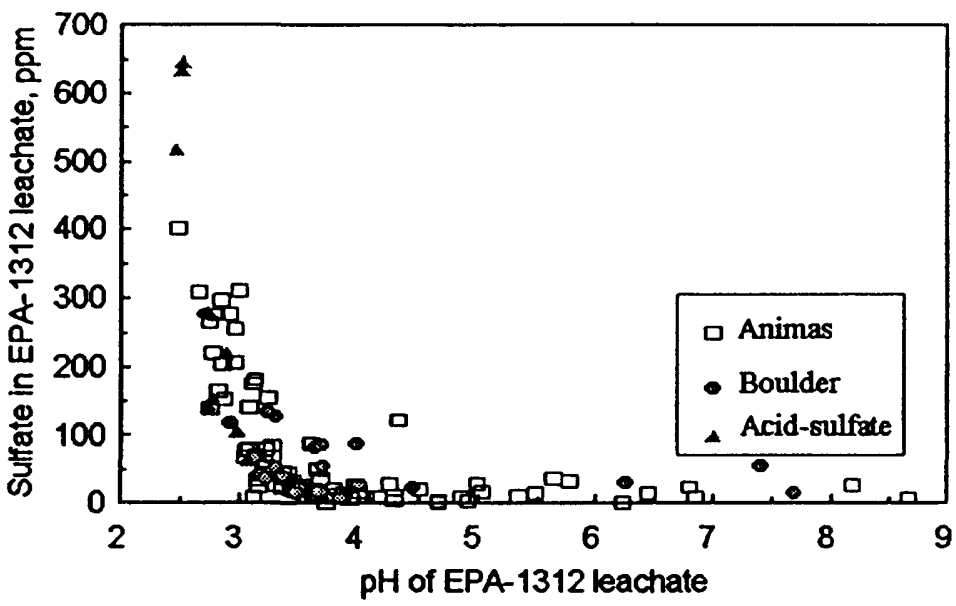

Figure 4 Plot of pH versus the concentration of sulfate (ppm) from the EPA-1312 leachates. Mineral deposit types from the Animas and Boulder watershed are shown using different symbols.

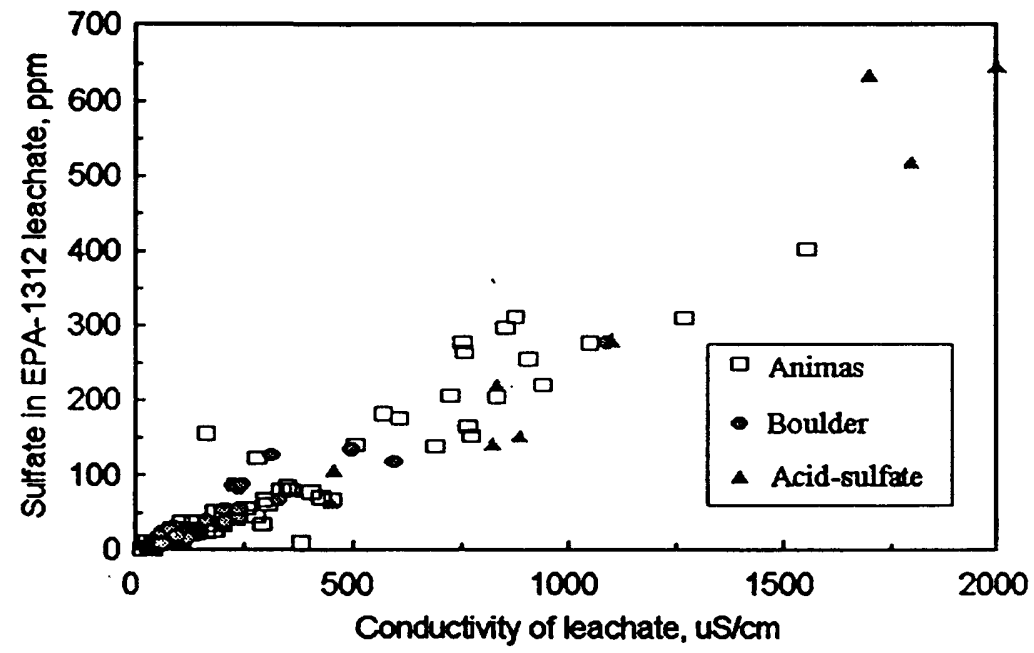

Figure 5 Plot of conductivity versus the concentration of sulfate (ppm) from the EPA-1312 leachates. Mineral deposit types from the Animas and Boulder watershed are shown using different symbols.

process predominantly releases the acid and metals stored in water-soluble sulfates produced during cycles of wetting and drying of the mine-waste material (Alpers et al., 1994).

For brevity, the following discussion of $\mathrm{pH}$, conductivity, dissolved metals, sulfate, and acidity are restricted to the results from the EPA-1312 leach method. Data from these studies are summarized on Figures 4-9. Figure 4 illustrates the systematic relationship of dissolved sulfate and $\mathrm{pH}$ in the leachates. The sulfidic mine-wastes from the acid-sulfate mineral deposits in the Animas River study area define the low pH, high dissolved-sulfate portion of the curve. Figure $S$ shows that conductivity is a reasonably good proxy for sulfate concentration. Figure 6 shows the relationship of dissolved zinc to $\mathrm{pH}$. The higher zinc concentrations generally occur in leachates with a pH $<4$; however, zinc can remain in solutions of higher pH. Figure 7 shows the relationship between $\mathrm{pH}$ and dissolved copper. The highest concentrations of copper are in solutions with $\mathrm{pH}<3.5$ and contain all of the samples from the acid-sulfate class of mineral deposits. The high concentrations of copper indicate that copper sorption onto iron colloids was not an important process in these laboratory extractions. Smith et al. (1993) have shown that for relatively elevated dissolved iron concentrations (1 $\mathrm{g} / \mathrm{L}$ ) in such solutions, copper is not significantly sorbed onto iron colloids at $\mathrm{pH}<4$. 


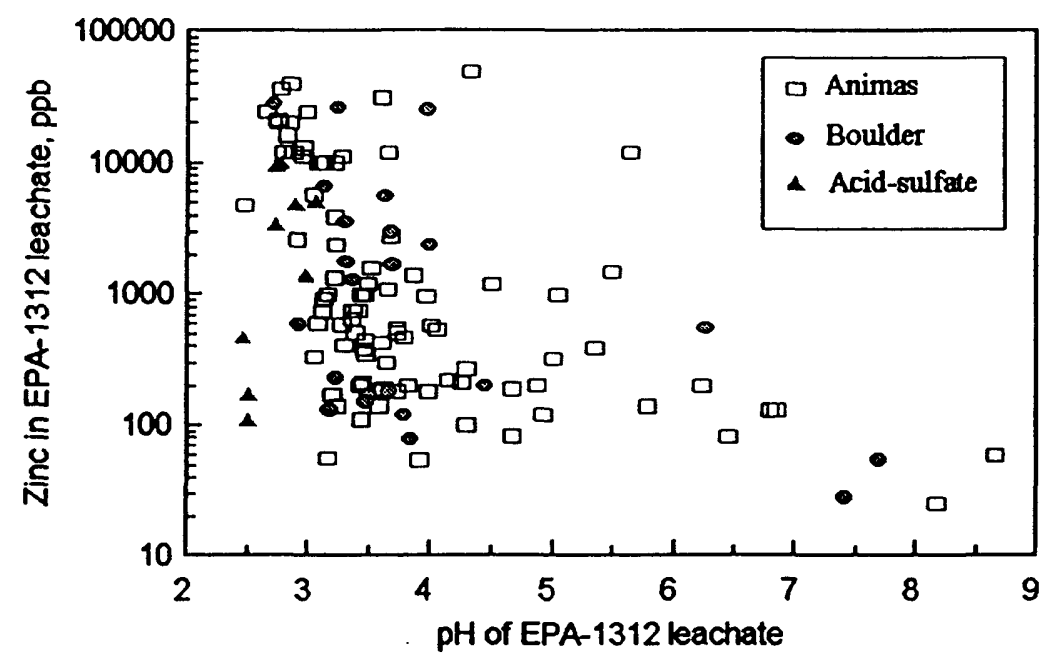

Figure 6 Plot of pH versus the concentration of dissolved zinc (ppb) from the EPA-1312 leachates. Mineral deposit types from the Animas and Boulder watershed are shown using different symbols.

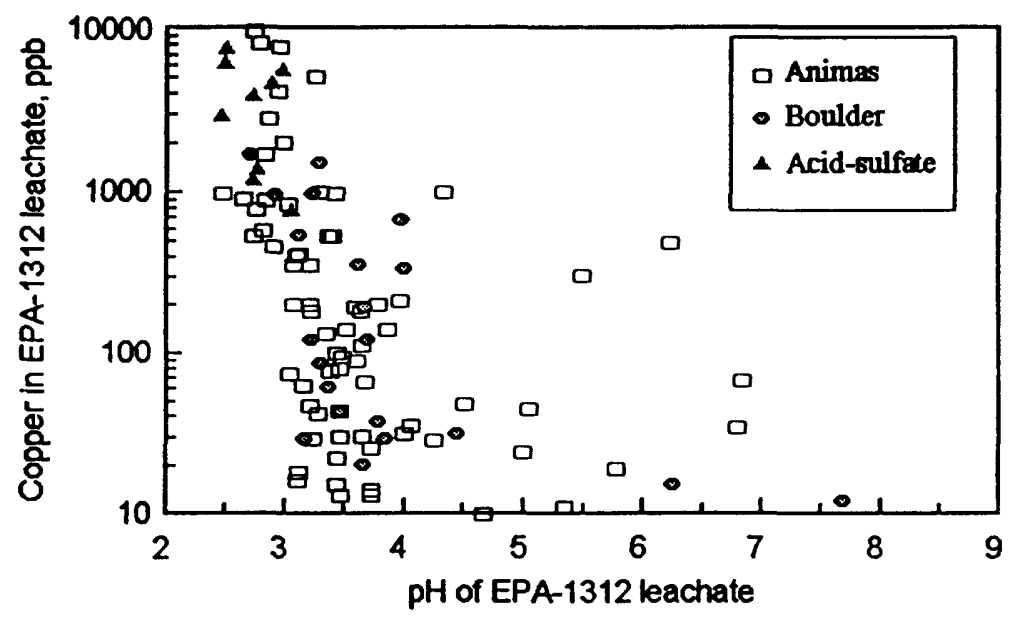

Figure 7 Plot of $\mathrm{pH}$ versus the concentration of dissolved copper (ppb) from the EPA-1312 leachates. Mineral deposit types from the Animas and Boulder watershed are shown using different symbols.

Figure 8 shows the pH of the leachates versus the NAP (Net Acid Production) of the samples. The correlation between NAP and leachate $\mathrm{pH}$ indicates the $\mathrm{pH}$ of the leachate may serve as an indicator of longterm acid-generating potential of the mine wastes, since the $\mathrm{pH}$ of the leachate is indirectly controlled by a sample's pyrite content and its associated NAP. On Figure 9, the ratio of dissolved iron in the EPA-1312 leachate to the total iron in the mine-waste sample is plotted against the $\mathrm{pH}$ of the leachate. The relationship between $\mathrm{Fe}_{(\text {(each) }} / \mathrm{Fe}_{(\text {lotal })}$ and $\mathrm{pH}$ indicates that $\mathrm{Fe}_{(\text {leach) }} / \mathrm{Fe}_{(\text {lotal })}$ is another measure of the long-term acid

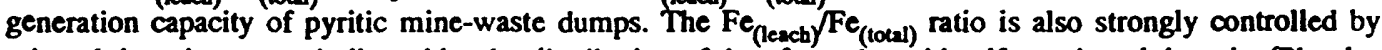
mineral deposit type, as indicated by the distribution of data from the acid-sulfate mineral deposits (Plumlee and Nash, 1995). For most of the mine-waste samples in this study, less then $0.1 \%$ of the iron is present in water-soluble mineral phases and the pH values of the EPA-1312 leach solutions do not go below 2.4. The more complete oxidation of samples in the NAP test, however, yielded solutions with pH values as low as 1.9.

\section{CHEMICAL RANKING OF MINE WASTES}

The numerous mine waste piles from polymetallic-vein deposits (97) and the few wastes from acid-sulfate deposits (9) that we studied in the laboratory, can be classified, or ranked, with regard to their potential for 


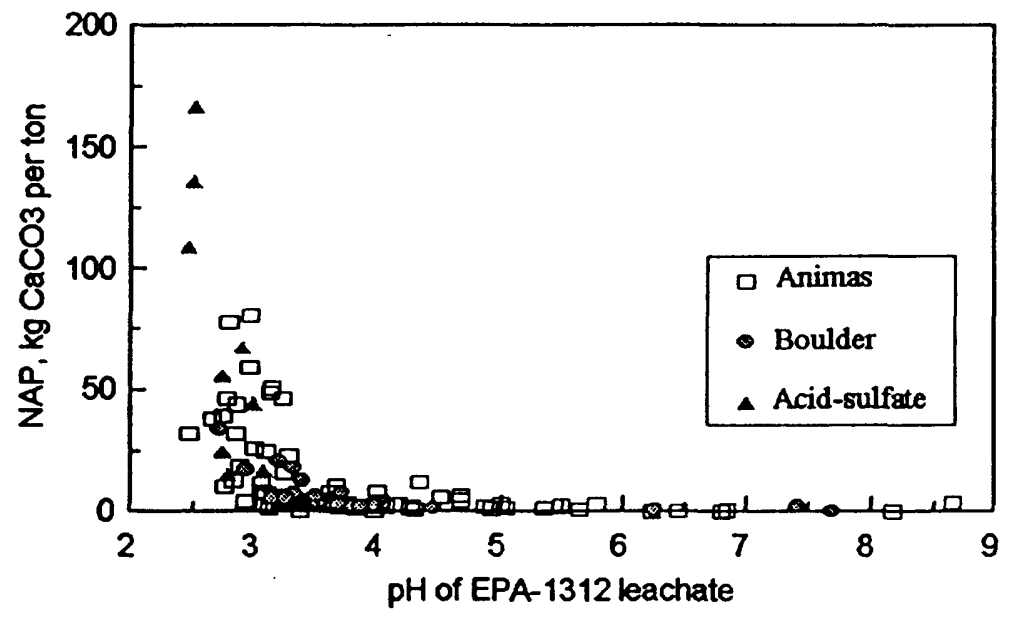

Figure 8 Plot of pH of the EPA-1312 leachate versus the total acidity from the $\mathrm{H}_{2} \mathrm{O}_{2}$ digestion expressed as kilograms equivalent $\mathrm{CaCO}_{3}$ per ton of mine-waste sample. Mineral deposit types from the Animas and Boulder watershed are shown using different symbols.

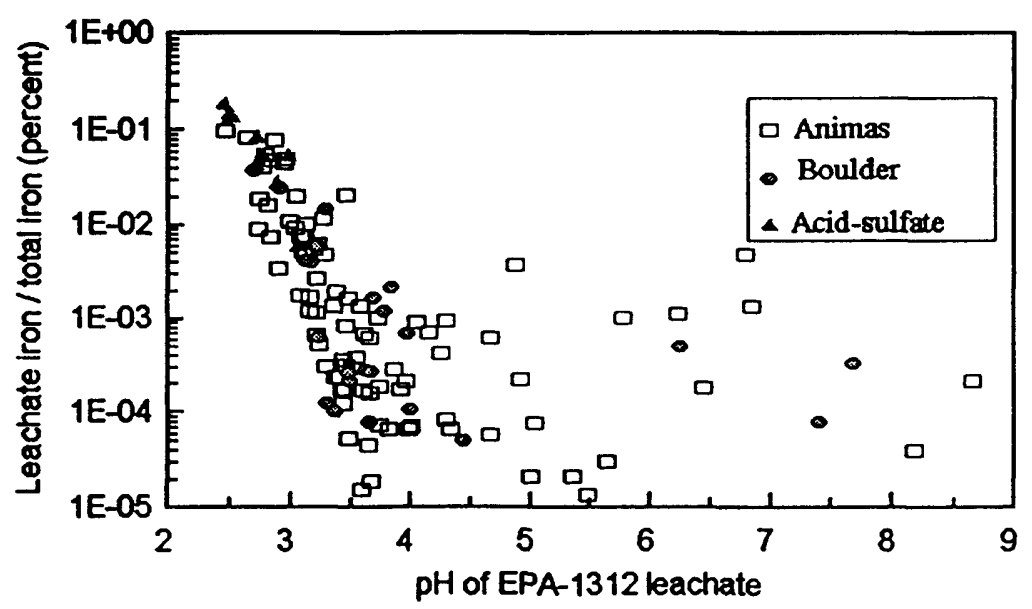

Figure 9 Plot of pH of the EPA-1312 leachate versus the ratio of dissolved iron in the EPA-1312 leachate/total iron in the mine-waste sample. Note that the samples that generate the low pH leachate waters have a higher percentage of the iron available in the form of water-soluble salts. The leachates from the mine-waste samples from the acid-sulfate deposits contain the highest percentage of dissolved iron with all but one of these samples plotting above the $0.01 \%$ line.

degrading water quality using chemical criteria. This was done to assist in identifying those mine wastes that may require remediation measures. The criteria described here are applicable to polymetallic-vein and acidsulfate mine wastes collected from the watersheds in this study, and are used to determine relative ranking within the study areas. This approach may be applied to other mineral deposit types and in other geographic settings.

Figure 10 is a plot of the NAP in $\mathrm{kg} \mathrm{CaCO}$ per ton, versus the sum of dissolved toxic metals As $+\mathrm{Cd}+\mathrm{Cu}+\mathrm{Pb}+\mathrm{Zn}$, defined here as $\mathrm{\Sigma TM}$ (sum of toxic metals in $\mu \mathrm{g} / \mathrm{L}$ or $\mathrm{ppb}$ ), in leachates of the 106 wastes studied. The data points on the figure can easily be segregated into three groups, as follows: group 1, with $\Sigma T M<1,000 \mu \mathrm{g} / \mathrm{L}$ and a NAP $<10 \mathrm{~kg} \mathrm{CaCO}$ per ton; group 2, with $\Sigma T M 1,000-5,000 \mu \mathrm{g} / \mathrm{L}$ and NAP of $<10$; group 3, with $\Sigma T M>5,000 \mu \mathrm{g} / \mathrm{L}$. The third group is subdivided into $3 \mathrm{a}$ and $3 \mathrm{~b}$ on the basis of NAP $>10 \mathrm{~kg}$ $\mathrm{CaCO}_{3}$ per ton. Group $3 \mathrm{~b}$ has the greatest potential for water quality degradation and should have the highest priority for removal to mitigate acidic waters at a watershed scale. 


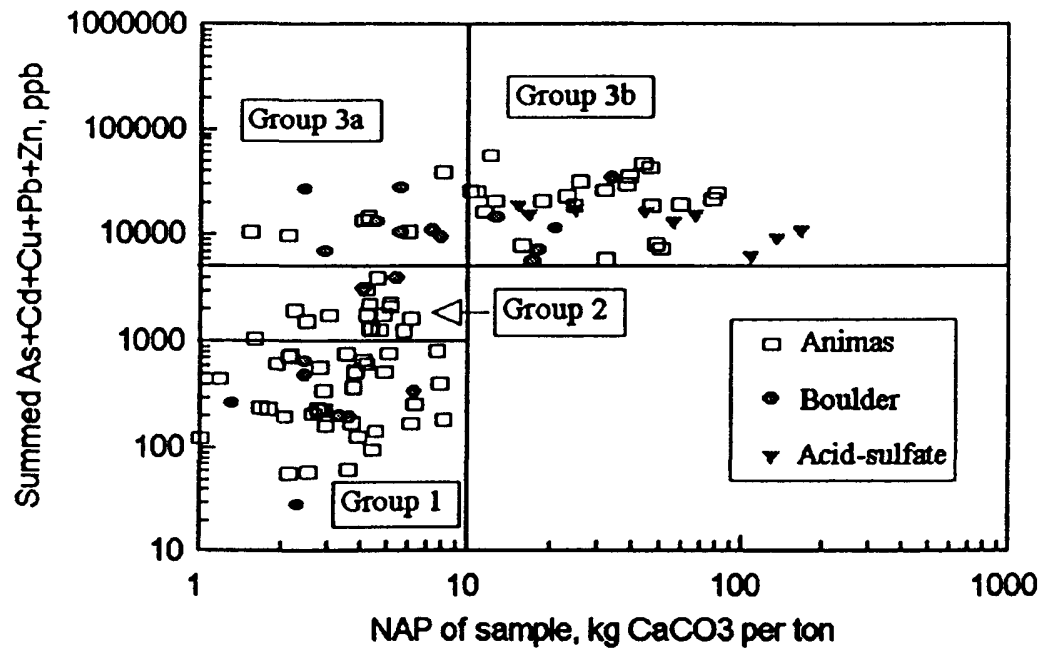

Figure 10 Plot of the net acid production (NAP) versus the sum of metals $\mathrm{As}+\mathrm{Cd}+\mathrm{Cu}+\mathrm{Pb}+\mathrm{Zn}$ in the EPA-1312 leach solution. The samples form three distinet groups or classes. The data are classified as follows: Group 1 is $\Sigma T M<1,000 \mu g / \mathrm{L}$ and a NAP $<10 \mathrm{~kg} \mathrm{CaCO}$ per ton, group 2 is $2 \mathrm{TM}>1,000 \mu g / \mathrm{L}$ and a NAP $<10 \mathrm{~kg} \mathrm{CaCO}$ per ton, and group 3 is $\Sigma T M>5,000 \mu g / L$. Note that all samples with NAP $>10 \mathrm{~kg} \mathrm{CaCO}$ per ton fall into group $3 \mathrm{~b}$, and have $\Sigma T M>5,000 \mu g / \mathrm{L}$.

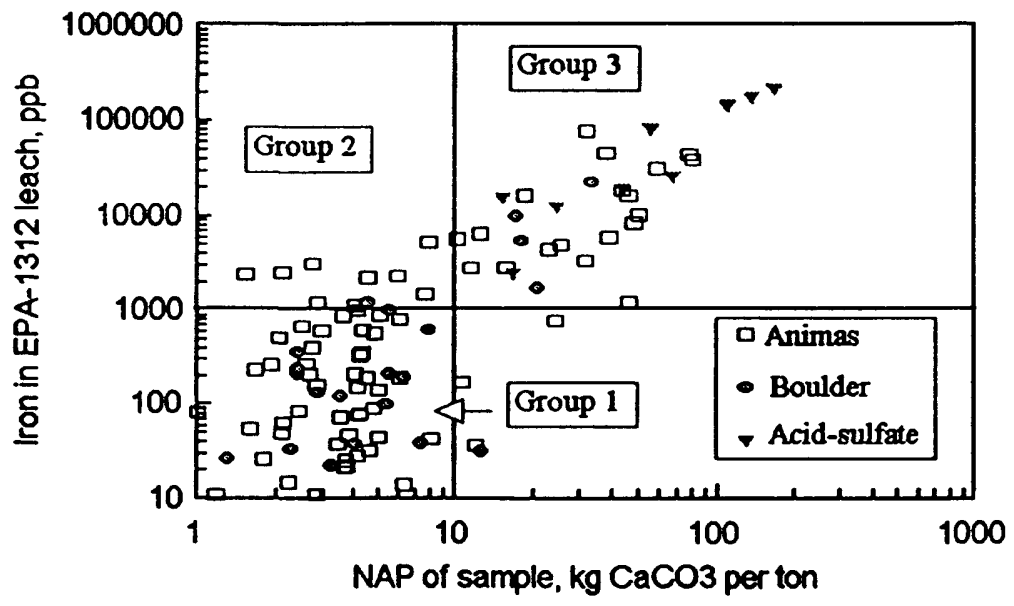

Figure 11 Plot of the net acid production (NAP) versus the dissolved iron concentration. The samples are grouped into three main classes: 1) those with dissolved iron less than $1,000 \mathrm{ppb}, 2)$ those with dissolved iron greater than 1,000 ppb and NAP $<10 \mathrm{~kg} \mathrm{CaCO}$ per ton, and 3) those with dissolved iron greater than $1,000 \mathrm{ppb}$ and $\mathrm{NAP}>10 \mathrm{~kg} \mathrm{CaCO}$ per ton.

A second criterion we propose is the relation between dissolved iron and NAP (Fig. 11). Samples with high dissolved iron and high NAP are readily segregated from samples with low dissolved iron concentration and low NAP ( $<10 \mathrm{~kg} \mathrm{CaCO}_{3}$ per ton). The separation value for dissolved iron is at about $1,000 \mu \mathrm{g} / \mathrm{L}$, and we have chosen this value because the "Class 1 Aquatic Life" standard for iron in Colorado streams is $1,000 \mu \mathrm{g} /$, regardless of alkalinity (Colorado Department of Health, 1984). In addition, Nordstrom et al. (1999) have shown "that a few mg of Fe per liter is unsafe or toxic for aquatic life in freshwaters." We have therefore used $1,000 \mu \mathrm{g} / \mathrm{L}$ dissolved iron and associated NAP of $>10$ as a cutoff for ranking mine wastes. It is important that a mine-waste sample be evaluated using all three factors: the NAP, the sum of toxic metals from water leachates, and the dissolved iron concentration. Waste pile size, accessibility, and hydrologic factors such as 
water running over the surface, proximity to surface waters or siting of the mine-waste material over a fractured or permeable substrate should also be considered.

\section{CONCLUSIONS}

Comparison of the data from the EPA-1312 leachates and the passive method leachates indicates the methods produce the same general results for both leachate $\mathrm{pH}$ and dissolved metal concentrations, but the EPA-1312 leachates may contain higher concentrations of dissolved metals than the passive leach method. The pH of leachate solutions is indirectly related to the NAP of the polymetallic-vein and acid-sulfate mine wastes studied here. An important consideration is that the values of water-soluble metals from either leach method may not reflect partitioning of some metals between the dissolved and the colloidal phases. The passive leach method is less labor intensive and may better simulate the natural weathering processes at the surface of minewaste piles.

We propose a system to rank mine-waste dumps on the basis of the net acid production (NAP) of wastes and the sum of dissolved, potentially toxic metals, and the dissolved iron of the leachates. This is a relative ranking model, applicable to the mineral deposit types and the watershed containing them. Application of the ranking model to other mineral deposit types and settings may result in different numerical values for classes, but still provide a method to determine relative ranking of mine wastes within a watershed.

\section{REFERENCES CTTED}

Alpers, C.N., D.W. Blowes, D.K. Nordstrom, and J.L. Jambor. 1994. Secondary minerals and acid mine-water chemistry. Paper presented at the Mineralogical Association of Canada, May 1994 at Waterloo, Ontario.

Briggs, P.H. 1996. Forty elements by inductively coupled plasma-atomic emission spectrometry. In Analytical methods manual of the Mineral Resource Surveys Program, U.S. Geological Survey, ed. B.F. Arbogast, 77-94. U.S. Geological Survey Open-File Report 96-525.

Briggs, P.H., and D.L. Fey. 1996. Twenty-four elements in natural and acid mine waters by inductively coupled plasma-atomic emission spectrometry. In Analytical methods manual of the Mineral Resource Surveys Program, U.S. Geological Survey, ed. B.F. Arbogast, 95-101. U.S. Geological Survey Open-File Report 96-525.

Buxton, H.T., D.A. Nimick, P. von Guerard, S.E. Church, A. Frazier, J.R. Gray, B.R. Lipin, S.P. Marsh, D. Woodward, B. Kimball, S. Finger, L. Ischinger, J.C. Fordham, M.S. Power, C. Bunck, and J.W. Jones. 1997. A science-based watershed strategy to support effective remediation of abandoned mine lands. Paper presented at the 4th International Conference on Acid Rock Drainage, May 31-June 5 at Vancouver, B.C. Canada.

Colorado Health Department. 1984. Basic Standards and Methodologies. 3.1.0 (SCCR 1002.8).

Church, S.E., B.A. Kimball, D.L. Fey, D.A. Ferderer, T.J. Yager, and R.B. Vaughn. 1997. Source, transport, and partitioning of metals between water, colloids, and bed sediments of the Animas River, Colorado. U.S. Geological Survey Open-File Report 97-151.

Desborough, G.A., and D.L. Fey. 1997. Preliminary characterization of acid-generating potential and toxic metal solubility of some abandoned metal-mining related wastes in the Boulder River headwaters, northern Jefferson County, Montana. U.S. Geological Survey Open-File Report 97-478.

Lapakko, K., and L.W. Lawrence. 1993. Modification of the net acid production (NAP) test. Paper presented at the Seventeenth Annual British Columbia Mine Reclamation Symposium, May 4-7 at Port Hardy, B.C.

Nash, J.T. 1999a. Geochemical investigations and interim recommendations for priority abandoned mine sites on U.S.D.A. Forest Service lands, Mineral Creek watershed, San Juan County, Colorado. U.S. Geological Survey Open-File Report 99-170.

Nash, J.T. 1999b. Geochemical investigations and interim recommendations for priority abandoned mine sites, BLM lands, Upper Animas River watershed, San Juan County, Colorado. U.S. Geological Survey OpenFile Report 99-323.

National Atmospheric Deposition Program (NRSP-3)/National Trends Network. 1999. NADP Program Office, Illinois State Water Survey, 2204 Griffith Drive, Champaign, IL 61820.

Nordstrom, D.K., C.N. Alpers, J.A. Coston, H.E. Taylor, R.B. McCleskey, J.W. Ball, S. Ogle, J.S. Cotsifas, and J.A. Davis. 1999. Geochemistry, toxicity, and sorption properties of contaminated sediments and pore waters from two reservoirs receiving acid mine drainage. In Contamination from Hardrock Mining, ed. D.W. Morganwalp and H.T. Buxton. U.S. Geological Survey Water-Resources Investigations Report 99-4018A.

Plumlee, G.S. and J.T. Nash. 1995. Geoenvironmental models of mineral deposits-fundamentals and 
applications. In Preliminary compilations of descriptive geoenvironmental mineral deposit models, ed. E.A. duBray, 1-9. U.S. Geological Survey Open-File Report 95-831.

Smith, K.S., W.H. Ficklin, G.S. Plumlee, and A.L. Meier. 1993. Computer simulations of the influence of suspended iron-rich particulates or trace metal-removal from mine-drainage waters. Paper presented at the 1993 Mined Land Reclamation Symposium, March 21-27 at Billings, Mont.

U.S. Emvironmental Protection Agency. 1986. Test methods for evaluating solid waste, Vol. I and II (SW-846) 3rd Edition, November. Updates are available through Revision 2B, published April 4, 1995. 


\title{
Quantifying Effects of Metal Loading from Mine Drainage
}

\author{
Briant A. Kimball', Kenneth E. Bencala', and Robert L. Runkel
}

\begin{abstract}
Thousands of abandoned and inactive mines are located in environmentally sensitive mountain watersheds. Cost-effective remediation of mining sites in these watersheds requires knowledge of the most significant sources of metals to surface waters. The significance of a given source not only depends upon the concentrations of a toxic metal, but also on the total mass, or load of metal added to the stream. To determine loads, we combined tracer-injection methods, to provide reliable discharge measurements on a watershed scale, with synoptic sampling, to provide spatially detailed concentration data. The resulting load profiles indicate which sources have the greatest effect on streams, where natural attenuation of metal loads occurs, and where ground-water inflows are located. This is part of the information needed for planning remediation of mine-drainage effects. The approach is illustrated by comparing zinc loading curves from three watersheds affected by mine drainage.
\end{abstract}

\section{INTRODUCTION}

Thousands of abandoned and inactive mines are located in environmentally sensitive mountain watersheds. Remediation of mining effects will be more cost-effective if planning is accomplished on a watershed scale, rather than on a site-by-site basis. Watershed-scale planning requires knowledge of (1) the most significant sources of metals to streams, (2) the extent of natural attenuation of metals entering a stream, and (3) the role of ground-water contributions to metal loading. Since 1997, the U.S. Geological Survey Abandoned Mine Lands (AML) Initiative has focused on identifying the geologic, geochemical, geophysical, hydrologic, and biologic information that is necessary to plan the most effective watershed-scale remediation. One part of this effort has been to develop an approach to quantify the effects of mine drainage on streams by using tracer injection and synoptic sampling in watersheds. Tracer injection quantifies stream discharge (Bencala et al., 1990 ) and synoptic sampling defines the detailed spatial variations in stream-water chemistry (Bencala and McKnight, 1987; Kimball et al., 1994; Kimball, 1997). The purpose of this paper is to illustrate the information that results from this approach, and to suggest how the information fits into the larger AML scheme.

The illustration draws upon data from three watersheds in the Rocky Mountains. Each of these areas is affected by historic mining, but the watersheds differ in their geologic and hydrologic characteristics. The tracer-injection and synoptic-sampling approach reveals how these differences result in characteristic patterns of metal concentration and loading in the streams. The loading profile of zinc, which affects the aquatic organisms in each of the streams, will be used to illustrate these distinctions.

\section{METHODS}

Quantification of metal loads requires accurate discharge measurements and representative chemical concentrations. However, quantifying discharge in mountain streams is complicated by the turbulence that results from pools, riffles, and cobbled bottoms. An even greater complication occurs because much of the water in mountain streams flows among the cobbles, in the hyporheic zone (Bencala et al., 1990, Harvey and

1 U.S. Geological Survey, Salt Lake City, Utah

2 U.S. Geological Survey, Menlo Park, California

${ }^{3}$ U.S. Geological Survey, Denver, Colorado 
Bencala, 1993). Thus, a traditional measurement of discharge in the stream channel can miss a substantial percentage of the flow, resulting in an underestimate of metal loads (Kimball, 1997).

\section{Quantification of Discharge}

Dilution of a continuously injected chemical tracer provides a way to measure discharge in mountain streams. Because the tracer follows the water through cobbled bottoms, it accounts for both the surface and hyporheic flow. When the tracer reaches a steady concentration at each stream site, discharge can be calculated by the amount of dilution at each successive stream site. For example, sites B through E (fig. 1) will have successively lower tracer concentrations, if discharge increases downstream. The conservation of mass requires that the load of tracer in the stream at $B$ must be equal to the load at $A$, upstream from the injection, plus the load from the injection (Table 1, equation 1). Also by the conservation of mass, the discharge at $B$ must equal the discharge at A plus the discharge of the injection. By using both equations, we solve for discharge downstream from the injection point (equation 2).

To calculate discharge at site $C$ and all subsequent sites downstream, we modify equation 2 by replacing $C_{B}$ with the tracer concentration at the particular site. Although $C_{A}$ remains in the numerator, a preinjection value of the tracer at the downstream site is needed to substitute for $C_{A}$ in the denominator (equation 3 ). If we have chosen a tracer with a background concentration less than detection, then this term would equal zero. Without a pre-synoptic measurement of the tracer, then the synoptic samples at sites B, C, and the inflow site I could be used to account for tracer dilution at site $C$, and the same calculation can be made along the rest of the study reach (equation 4 ).

During base-flow conditions, tracer dilution allows the detection of relatively small inflows of water, on the order of a few percent, and also makes it possible to measure discharge at a large number of synoptic sampling sites in 1 day. Chloride and bromide salts of sodium and lithium typically are suitable tracers; lithium works well in streams with low $\mathrm{pH}$, and chloride and bromide work well in streams with higher $\mathrm{pH}$. Dye tracers have the disadvantage of being unstable at low $\mathrm{pH}$ and of sorbing to solids and organic matter in the hyporheic zone (Bencala et al., 1986). Zellweger et al. (1988) provides a more detailed description of tracer-injection methods.

\section{Quantification of Loading}

To quantify loads on a watershed scale, we divide the stream into segments by collecting samples upstream and downstream from visible inflows (B, C, and D, fig. 1) and at other sites that will help quantify subsurface inflows (E, fig. 1). Synoptic sampling provides a detailed, longitudinal profile of load for stream sites and inflows at a point in time. The influence of any particular inflow is measured by its load, not just its concentration. If two inflows have the same concentration, the one with the greater discharge will have a greater influence on the downstream concentration. Logistically,-not all the water entering the stream can be sampled because some of it enters as diffuse subsurface inflow. Thus, we sample as many inflows as is practical to define the possible range of inflow concentrations that account for the increases of load in the stream.

Sampled Instream Load. The mass balance at site $\mathrm{C}$ includes the instream load at site B plus the inflow load contributed by all the surface and subsurface inflow between sites B and C (equation 5). In this illustration, the inflow load includes a tributary inflow, which can be sampled at site I. The total inflow load, however, can be a combination of visible inflow, seeps, springs, and diffuse subsurface inflow. We quantify the total volume of inflow as the difference in stream discharge between sites $B$ and $C$. For the instream load at $C$ to exactly equal the sum of instream load at site B and the inflow load, the tributary concentration, $C_{1}$, must represent the discharge-weighted average concentration of all the water entering the stream between sites $B$ and $C$. This discharge-weighted average, which we call the effective inflow concentration, can be calculated for a stream segment by rearranging equation 5 . An increase of load in the stream accounts for the influence of one or more metal sources in that particular segment of the watershed. As instream load changes downstream, we designate the change between sites as $\Delta M_{s}$; the change quantifies the minimum amount of loading for each stream segment (equation 6). The change also is equal to the product of the effective inflow concentration and the change in discharge between sites $B$ and $C$ (equation 6 ). 


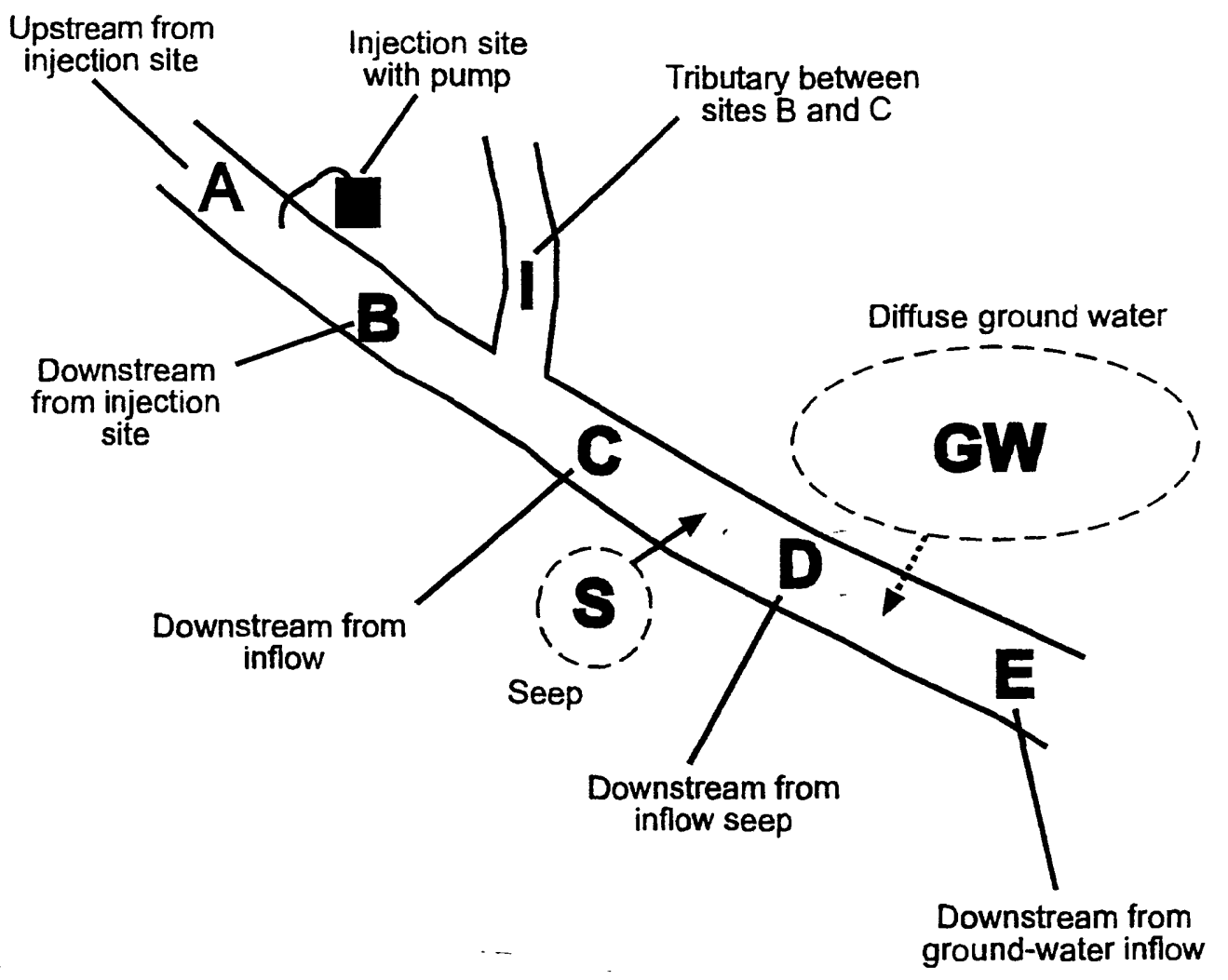

Figure 1 Schematic diagram showing mass-balance calculations around an inflow to a stream. See Table 1 for definition of the variables.

The sampled instream load can increase or decrease downstream. For example, with a net decrease in load in the segment between $C$ and $\mathrm{D}, \Delta M_{s}$ is less than 0 , as suggested in fig. 2a. This would indicate a net removal of load due to physical, chemical, or biological processes. If there is no net change in load between two sites, $\Delta M_{s}$ equals zero; indicating either no loading or that the loading and removal processes are in balance.

Sampled Inflow Load. If we substitute the sampled inflow concentration for the effective inflow concentration in equation 6 , we have a definition for the change of the sampled inflow load, which we designate as $\Delta M_{1}$ (equation 7). The comparison between $\Delta M_{s}$ and $\Delta M$, depends on whether our sampled inflow concentration is representative of the effective inflow concentration (Bencala and Ortiz, 1999). Discrepancies between the two may indicate that there is "unsampled" inflow entering the stream that has a metal concentration that is different from the inflows we have sampled. Samples from the tributaries, seeps, springs, and subsurface water (from wells, pits, or drive points) help evaluate how well we have accounted for effective inflow concentrations with the inflow load.

Summation of Total Load. We can further utilize the loading data by summing the changes for each segment. The summation of sum of positive values of $\Delta M_{s}$ leads to a minimum estimate of the total load added to the stream (Fig. 2b). In our example, there was a net loss between $C$ and D, causing the summation of total load to be greater than the sampled instream load downstream from that segment. At the end of the study reach, the difference between sampled instream load and the summation of total load accounts for the load removed through natural attenuation in the stream channel. 
Table 1. Equations defining calculated quantities in tracer-injection studies [Subscripts correspond to sites illustrated in figure 1]

\begin{tabular}{|c|c|c|}
\hline Calculated quantity & Equation & Variables \\
\hline $\begin{array}{l}\text { 1) Mass balance of load and } \\
\text { discharge downstream } \\
\text { from the injection site }\end{array}$ & $\begin{aligned} M_{B} & =C_{n} Q_{\mu}=C_{A} Q_{A}+C_{n \mu} Q_{k j} \\
Q_{B} & =Q_{A}+Q_{i n j}\end{aligned}$ & $\begin{array}{l}M_{B}, \text { Load at site B } \\
C_{B}, \text { Concentration at site B } \\
Q_{B} \text {, Discharge at site B } \\
C_{A} \text {, Concentration at site A } \\
Q_{A}, \text { Discharge at site A } \\
C_{I n j,} \text { Concentration of injectate } \\
\quad \text { solution } \\
Q_{I n j,} \text { Discharge of injection } \\
\quad \text { pump } \\
\end{array}$ \\
\hline $\begin{array}{l}\text { 2) Discharge at first site } \\
\text { downstream from tracer } \\
\text { injection. }\end{array}$ & $Q_{B}=\frac{Q_{l n j}\left(C_{l n j}-C_{A}\right)}{\left(C_{B}-C_{A}\right)}$ & All variables defined above \\
\hline $\begin{array}{l}\text { 3) Discharge at subsequent } \\
\text { downstream sites based } \\
\text { on pre-synoptic samples }\end{array}$ & $Q_{c}=\frac{Q_{i n i}\left(C_{i n j}-C_{A}\right)}{\left(C_{c}-C_{c}^{p}\right)}$ & $\begin{array}{l}Q_{c}, \text { Discharge at downstream } \\
\text { site } \\
C_{c}, \text { Concentration of tracer at } \\
\text { downstream site } \\
C_{C}^{P} \text {, Pre-injection } \\
\text { concentration of tracer at } \\
\text { downstream site }\end{array}$ \\
\hline $\begin{array}{l}\text { 4) Discharge at subsequent } \\
\text { downstream sites based } \\
\text { on synoptic inflow } \\
\text { samples }\end{array}$ & $Q_{c}=\frac{Q_{B}\left(C_{B}-C_{I}\right)}{\left(C_{c}-C_{I}\right)}$ & $\begin{array}{l}C_{l} \text {. Synoptic concentration of } \\
\text { tracer at downstream site }\end{array}$ \\
\hline 5) $\frac{\text { Sampled instream load at }}{\text { subsequent stream sites }}$ & $M_{c}=C_{c} Q_{c}=C_{B} Q_{B}+C_{I}^{E}\left(Q_{c}-Q_{B}\right)$ & $\begin{array}{l}M_{C}, \text { Load at site } C \text { or } \\
\text { subsequent sites } \\
\text { downstream } \\
C^{E}{ }_{l} \text { Effective inflow } \\
\text { concentration }\end{array}$ \\
\hline 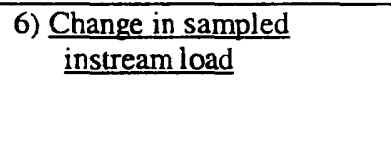 & $\begin{aligned} \Delta M_{s} & \equiv C_{C} Q_{c}-C_{B} Q_{B} \\
& =C_{I}^{E}\left(Q_{c}-Q_{B}\right)\end{aligned}$ & $\begin{array}{l}\Delta M_{S}, \text { Net change in load } \\
\text { between sites B and C }\end{array}$ \\
\hline $\begin{array}{l}\text { 7) Change in sampled inflow } \\
\underline{\text { load }}\end{array}$ & $\Delta M_{1} \equiv C_{1}\left(Q_{c}-Q_{B}\right)$ & $\begin{array}{l}\Delta M_{l} \text { Net change in load } \\
\text { between sites B and C } \\
\text { based on sampled inflow } \\
\text { concentration } \\
C_{l}, \text { Sampled inflow } \\
\text { concentration }\end{array}$ \\
\hline
\end{tabular}

Summation of Inflow Load. We also can sum the values of inflow load for all the stream segments. At the end of the study reach, this sum quantifies the load accounted for by inflow samples. A difference between summations of total and inflow loads leads to a direct comparison between sampled and effective inflow concentrations (Fig. 2c). The values of $\Delta M_{s}$ and $\Delta M_{1}$ for individual subreaches can have three outcomes:

(1) If $\Delta M_{s}$ is equal to $\Delta M$, between stream sites, then the sampled inflow concentration is representative of the effective inflow concentration. This situation is not common and is not 
shown in the example in Figure 2c. Because mine drainage often mixes with catchment water that is unaffected by mining, sampled inflow concentrations generally are lower than the effective inflow concentrations.
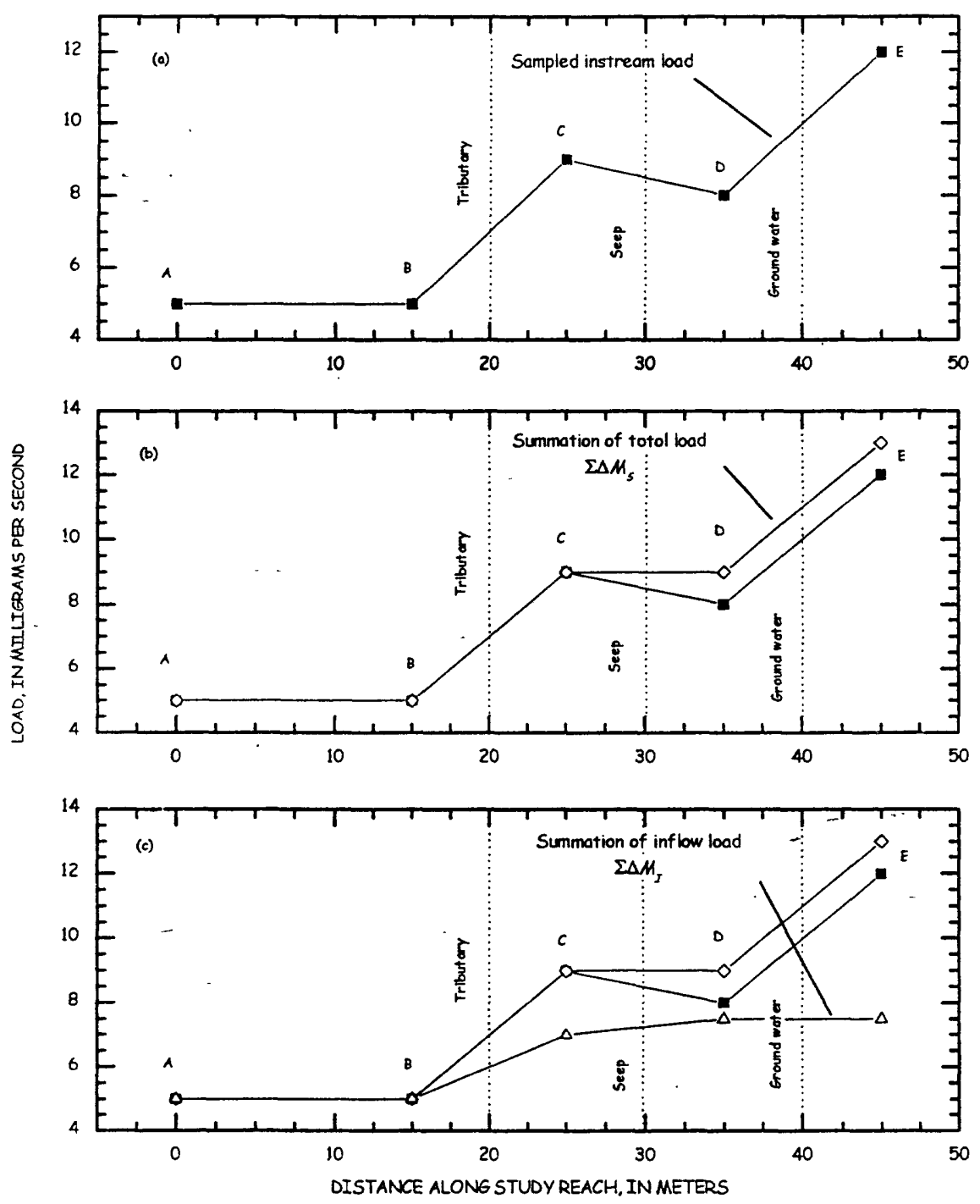

Figure 2 Examples of load profiles for (a) sampled instream load, (b) summation of total load, and (c) summation of inflow load

(2) If $\Delta M_{s}$ is greater than $\Delta M_{p}$ then the effective inflow concentration is greater than the sampled inflow concentration. The summation of total load is greater than the summation of inflow load between $B$ and $C$ and between $D$ and $E$ (fig. $2 c$ ). Between sites $D$ and $E$, there may not have been a sample of the ground-water inflow, but the increase of instream load was observed at site 
E. The divergence of the summation of total load from the summation of inflow load can be an indication of diffuse subsurface inflow that increases metal load.

(3) If $\Delta M_{s}$ is less than $\Delta M_{r}$, then the effective inflow concentration is less than the sampled inflow concentration. Between $C$ and $D$, there was a net loss of metal from the stream, but the summation of inflow load indicated a slight increase. With a sampled inflow concentration, the value of $\Delta M$, might be added to the summation of total load if $\Delta M_{s}$ is negative.

The load profiles in Figure 2c are typical of many streams affected by mine drainage. However, each stream is unique because of local variations in watershed characteristics.

\section{RESULTS AND DISCUSSION}

Given the framework of the sampled instream load, the summation of total load, and the summation of inflow load, we are able to address some important questions about a watershed. What are the principal sources of metal loading? What is the extent of natural attenuation in the stream? Are there important sources of subsurface inflow that contribute to the metal load in the stream? A comparison of three streams affected by mine drainage will show how these questions can be answered.

\section{Little Cottonwood Creek, Utah}

Background. Little Cottonwood Creek is a neutral-pH stream draining the Alta mining district in the Wasatch Mountains of Utah. Details of the study in Little Cottonwood are reported in Kimball et al. (1999b). Synoptic sampling along 8 kilometers of Little Cottonwood Creek included 45 stream sites and 32 inflows. Discharge, which was determined by dilution of a sodium chloride tracer, increased from 45 to 910 liters per second (L/s) along the study reach. Inflows along individual subreaches ranged from seepage of less than $1 \mathrm{~L} / \mathrm{s}$ to a welldefined tributary of $150 \mathrm{~L} / \mathrm{s}$. Zinc concentrations in the stream ranged from 0.01 to 0.32 milligrams per liter $(\mathrm{mg} / \mathrm{L})$, and $\mathrm{pH}$ was higher than 8.0 .

There are two main mine-drainage tunnels that discharge water to the stream. First, the combined Howland Tunnel inflow enters the stream at $1,403 \mathrm{~m}$ (fig. 3a). Second, the Wasatch Tunnel has a substantial mine pool behind a bulkhead. When the mine pool behind the bulkhead is about 300 feet deep, it discharges to the stream through a small adit and through bedrock fractures near $2,470 \mathrm{~m}$. Part of the mine-pool water is used for cooling a power generator at Snowbird ski resort; the cooling water is discharged at 2,926 m. The unused water is discharged at 3,068 and $3,069 \mathrm{~m}$.

Zinc-loading profile. The most notable features of the zinc-loading profile are the discrete increases in zinc load where mine tunnels discharge to the stream (Fig. 3a). The first increase is from the combined Howland Tunnel and the second, larger increase is from the Wasatch Tunnel. Of the separate inflows from the Wasatch Tunnel, the greatest loading occurs from the cooling water at $-2,926 \mathrm{~m}$ The overflow water was being experimentally treated during the tracer injection, and so the overflows at 3,068 and 3,069 m did not contribute to the zinc load (Douglas Evans, Salt Lake Cuunty Servicc District, oral commun., 1998). Another important feature is the substantial, consistent attenuation of the zinc load downstream from the large increase at $3,037 \mathrm{~m}$. The loss of zinc load is quantified by the difference between the summation of total load and the sampled instream load at the end of the study reach; about half the dissolved zinc load is lost from the water column to the streambed. Upstream from the inflow of Wasatch Tunnel cooling water, the summation of inflow load accounted for almost the entire total load (Fig. 3a). Thus, the sampled inflow concentrations were representative of the effective inflow concentrations. Downstream from $3,069 \mathrm{~m}$, however, and particularly at the Tanners Flat campground, there was substantial unsampled inflow. There are no mine-drainage tunnels in that part of the study reach, and so the inflows mostly are from subsurface inflow.

\section{Cement Creek, Colorado}

Background. Cement Creek is an acidic, metal-rich tributary of the Animas River in the San Juan Mountains of southwestem Colorado. It is located mostly within the Silverton caldera structure, an area with extensive alteration, much of which has been mined. Details of the study are reported in Kimball et al. (1999a). Synoptic samples along 12 kilometers of Cement Creek included 57 stream sites and 45 inflows. Discharge was determined by dilution of a lithium chloride tracer and increased from 45 to $702 \mathrm{~L} / \mathrm{s}$ along the study reach. There were 10 distinct inflows greater than $20 \mathrm{~L} / \mathrm{s}$ each, which accounted for more than 60 percent of the increase in flow. Zinc concentrations in the stream ranged from 0.02 to $1.2 \mathrm{mg} / \mathrm{L}$; median pH was 3.88 .

Zinc loading profile. There was a substantial increase of zinc load along the entire study reach of Cement Creek; the increases were more evenly dispersed among stream segments than in Little Cottonwood Creek (Fig. 3b). The dispersed loading could be a result of the widespread alteration of the Silverton caldera. Because of the low $\mathrm{pH}$ of the stream, zinc was mostly conservative. Zinc load decreased in a few subreaches, which caused the 
summation of total load and the sampled instream load to diverge. These reactive subreaches were downstream from inflows with relatively high $\mathrm{pH}$, and zinc was removed from the stream like most likely by sorption to the iron colloidal material and organic matter that coated the streambed. The difference between the summation of total load and the sampled instream load indicates the extent of natural attenuation of zinc along the study reach. The summation of inflow load was substantially less than the summation of total load, indicating substantial unsampled inflow. This mostly occurred in discrete subreaches of the stream near Prospect Gulch, Ohio Gulch, and the Lower Bog, where ground-water inflows entered the stream along fractures.

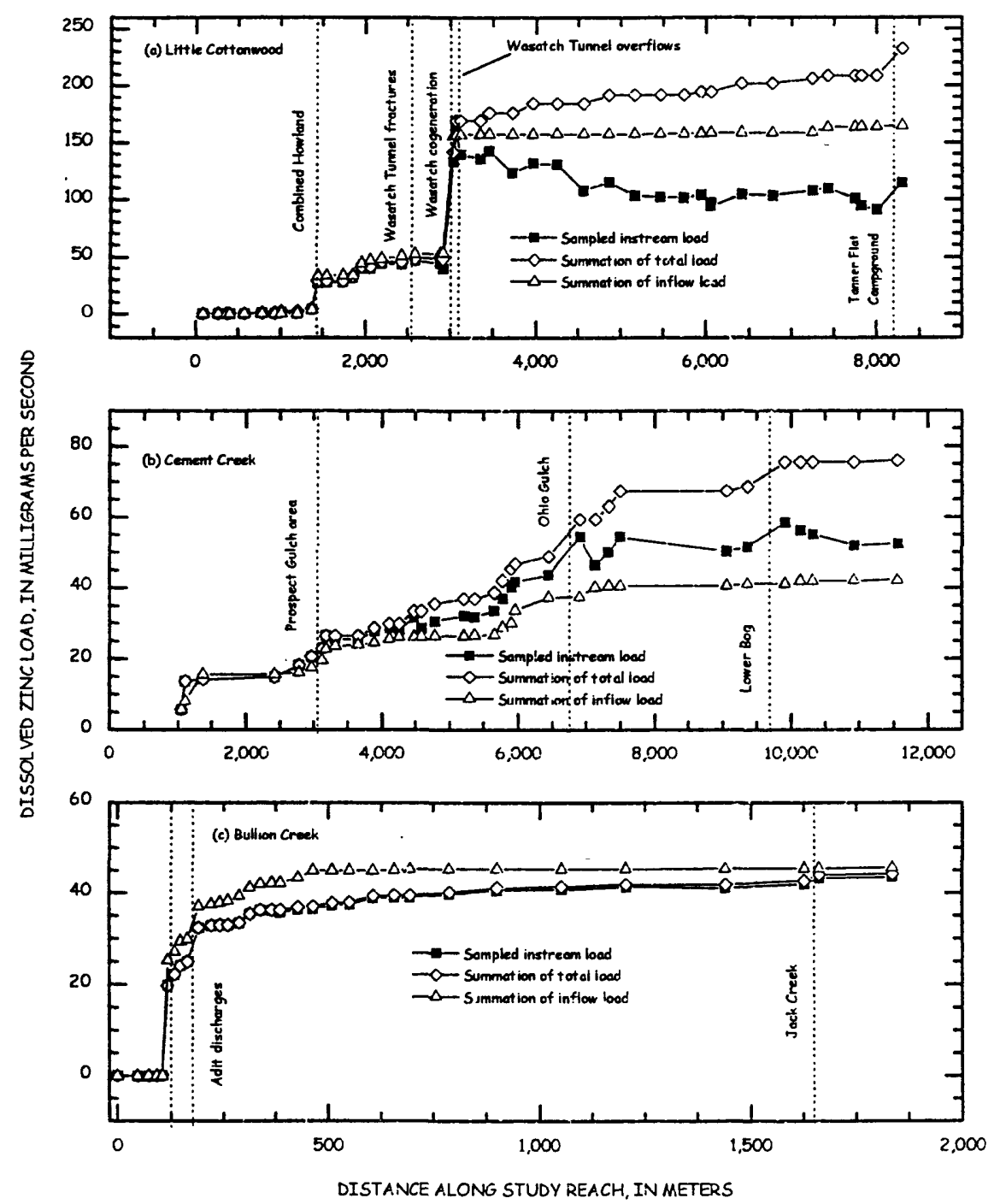

Figure 3 Zinc-loading profiles for (a) Little Cottonwood Creek, (b) Cement Creek, and (c) Bullion Creek 


\section{Bullion Creek, Montana}

Background. Bullion Creek is a tributary of Jack Creek near Boulder, Montana. It is acidic. with a median pH of 3.73 upstream from its confluence with Jack Creek. It receives drainage from the adit of the Bullion Mine. Details of the study are unpublished at the present time (B.A. Kimball, U.S. Geological Survey, unpublished data). A sodium chloride tracer was used to quantify discharge for 33 stream sites and 11 inflovs along a 2kilometer study reach. Discharge increased from 3 to $26 \mathrm{~L} / \mathrm{s}$ along the study reach. Zinc concentration in the stream ranged from less than 0.01 to $8.2 \mathrm{mg} / \mathrm{L}$.

Zinc-loading profile. Zinc loading into Bullion Creek almost completely occurred along the first $500 \mathrm{~m}$ of the study reach, and most of it was from just 2 inflows (Fig. 3c). There were relatively few inflows compared to the other streams, most likely because of the low transmissivity of the bedrock (Mike Cannon, U.S. Geological Survey, unpub. Data, 1998). Comparison of the summation of total load and the sampled instream load indicates that there is essentially no attenuation of zinc load; however, the summation of inflow load is greater than the summation of total load and the sampled instream load, a condition that did not occur in the other streams. There are two plausible explanations for this. First, the inflows could account for more loading than that measured in the stream because zinc was removed from the water rapidly, before the water reached the downstream sampling sites. Second, the effective inflow concentration of zinc could have heen lower than the sampled inflow concentration. In Bullion Creek, there was substantial deposition of iron precipitates on the streambed, and so the field observations favor the first explanation that zinc was lost to the streambed.

\section{CONCLUSIONS}

The contrasts among these three streams indicate the effectiveness of the tracer-injection and synopticsampling methods in providing a blueprint for the loading and the chemicai processes in specific watersheds. First, there was a distinct difference between the general pattern of Cement Creek, and the patierns of Little Cottonwood and Bullion Creeks. Cement Creek had many sources of loading that were distributed along the stream. With many distributed sources, remediation in Cement Creek would be very difficult, and efforts on individual sources would only affect a small percentage of the total zinc load. Much of this dispersed lcading could be from non-mining sources. In fact, the dispersed pattern of the loading profile for Cernent-Creek could be a result of extensive inflow from both mining and non-mining sources. In contrast, Little Cottonwood and Bullion Creeks had discrete sources. Because most of the loading in those watersheds came from well-defined adits and mine-drainage tunnels, remediation could be focused to accomplish a substantial removal of metal loads.

Differences in chemical and hydrologic processes also were apparent. The high $\mathrm{pH}$ of Little Cottonwood Creek caused attenuation of zinc along a substantial part of the study reach. In Cement Creek, however, zinc was removed only in mixing zones where higher $\mathrm{pH}$ occured. In Bullion Creek, despite the low $\mathrm{pH}$, the zinc was removed, perhaps the high concentrations of zinc caused sorption to the iron colloids on the streambed. The extent of unsampled inflow was greatest in the Cement Creek watershed, which is the area with the greatest amount of alteration, and the mosl affected by fractures that could bring ground water to the stream.

The distinct differences among these watersheds point out the need for careful study of individual watersheds to prepare for remediation. Data from tracer-injection and synoptic sampling. combined with geologic and biologic data, provide a useful tool to gain some of the information that is needed to make remediation decisions.

\section{ACKNOWLEDGMENTS}

Studies in Cement Creek, Colorado, and Bullion Creek, Montana, were supported by tree Toxic Substances Hydrology Program of the U.S. Geological Survey. The study in Little Cottonwood Creek, Utah, was supported by the U.S. For est Service.

\section{REFERENCES}

Bencala, K.E. and D.M. McKnight. 1987. Identifying in-stream variability: Sampling iron in an acidic stream. In Chemical Quality of Water and the Hydrologic Cycle, eds. R.C. Averett and D.M McKnight, 255-69. Chelsea, Michigan, Lewis Publishers, lnc.

Bencala, K.E., D. M. McKnight, and G.W. Zellweger. 1990. Characterization of Transport in an Acidic and Metal-rich Mountain Stream Based on a Lithium Tracer Injection and Simulations of Transient Storage. Waler Res. Res. 26, 989-1000.

Bencala, K.E., and R.F. Ortiz. 1999. Theory and (or) reálity: analysis of sulfate mass-balance at Summitville, Colorado poses process questions about estimation of metal loadings. In U.S. Geclogical Survey Toxic 
Substances Hydrology Program-Proceedings of the Technical Meeting, Charleston, South Carolina, March 8-12, 1999-Volume 1 of 3-Contamination from Hardrock Mining, eds. D. W. Morganwalp and H.T. Buxton, p.119-122. U.S. Geological Survey Water-Resources Investigations Report 99-4018A.

Bencala, K.E., D.M. McKnight, G. W. Zellweger, and J. Goad. 1986. The stability of rhodamine WT dye in trial studies of solute transport in an acidic and metal-rich stream. U.S. Geological Survey WaterSupply Paper 2310.

Harvey, J.W., and K.E. Bencala. 1993. The Effect of Streambed Topography on Surface-Subsurface Water Exchange in Catchments. Water Res. Res., 29: 89-98.

Harvey, J.W., and C.C. Fuller. 1998. Effect of enhanced manganese oxidation in the hyporheic zone on basin-scale geochemical mass balance. Water Res. Res., 34, 623-636.

Kimball, B.A. 1997. Use of tracer injections and synoptic sampling to measure metal loading from acid mine drainage. U.S. Geological Survey Fact Sheet FS-245-96. (Online at http://wwwdutslc.wr.usgs.gov/usgsabout/fs245/245.html)

Kimball, B.A., R.E. Broshears, K.E. Bencala, and D.M. McKnight. 1994. Coupling of hydrologic transport and chemical reactions in a stream affected by acid mine drainage. Environ. Sci. Technol., 28, 20652073.

Kimball, B.A., R.L. Runkel, K.E. Bencala, and Katherine Walton-Day. 1999b. Use of tracer-injection and synoptic-sampling studies to quantify effects of metal loading from mine drainage. In U.S. Geological Survey Toxic Substances Hydrology Program-Proceedings of the Technical Meeting, Charleston, South Carolina, March 8-12, 1999-Volume 1 of 3-Contamination from Hardrock Mining, eds. D.W. Morganwalp and H.T. Buxton, p. 31-36. U.S. Geological Survey Water-Resources Investigations Report 99-4018A.

Kimball, B.A., R.L. Runkel, and L.J. Gerner. 1999a. Quantification of mine-drainage inflows to Little Cottonwood Creek, Utah, using a tracer-injection and synoptic-sampling study, submitted to Environmental Geology.

Zellweger. G.W., K.E. Bencala, D.M. McKnight, R.M. Hirsch, and B.A. Kimball. 1988. Practical aspects of tracer experiments in acidic, metal enriched streams. In U.S. Geological Survey Toxic Substances Hydrology Program -- Surface-Water Contamination: Proceedings of the Technical Meeting, Denver, Colorado, February 2-4, 1987, U.S. Geological Survey Open-file Report 87-764., ed. G.E. Mallard, 125-130. W'ashington, D.C., U.S. Government Printing Office. 


\title{
An Investigation of the Partitioning of Metals in Mine Wastes Using Sequential Extractions
}

\author{
Reinhard W. Leinz', Stephen J. Sutley', George A. Desborough', and Paul H. Briggs'
}

\begin{abstract}
The mode of occurrence of metals in mine wastes is investigated using sequential extractions. Metals are extracted from some or all of seven operationally-defined phases: water-soluble, ion-exchangeable, carbonate, amorphous Fe-oxide, crystalline Fe-oxide, sulfide, and silicate. The quantity of-metals extracted from each phase varies with particle size. The presence of jarosite (potassium end-member formula, $\left.\mathrm{KFe}_{3}\left[\mathrm{SO}_{4}\right]_{2}[\mathrm{OH}]_{6}\right)$ influences the selection of the procedure for extracting the crystalline Fe-oxide phase. Anglesite $\left(\mathrm{PbSO}_{4}\right)$ and cerussite $\left(\mathrm{PbCO}_{3}\right)$ are extracted as several phases. Extraction results can be explained only in part by X-ray diffraction (XRD) mineralogy because of lack of specificity of the extraction procedures, relatively high XRD detection limits, and the presence of $40 \%$ XRD-amorphous matter in each waste. The increasing chemical strength of the sequentially applied methods provides a basis for judging metal availability, water-soluble metals being most available and silicate-bound metals being least available.
\end{abstract}

\section{INTRODUCTION}

Sequential extractions have been used primarily for the chemical speciation of metals in soils and sediments. Tessier et al. 1979, nuaintained that sequential extractions can furnish detailed information about the mode of occurrence, biological availability, and mobilization of trace metals in sediments. Accordingly, when applied to mine wastes, the extractions may provide information useful for evaluating the near and long term effects of wastes on the environment.

In sequential extractions, metals are extracted from mineral phases that are operationally defined. This means that the procedure itself defines the extracted phase. A procedure that preferentially extracts metals associated with any one mineral or component of the sample is often referred to as phase specific, although total specificity is highly improbable if not impossible. Commonly, metals are extracted from several, or all of the following operationally-defined phases and in the given order: (1) metals present in water-soluble form; (2) ion-exchangeable metals; (3) metals associated with carbonates; (4) metals associated with amorphous iron and manganese oxides $\left(\mathrm{Fe}-\mathrm{MnOx}_{\text {am }}\right) ;(5)$ metals bound to crystalline iron oxides $\left(\mathrm{FeOx}_{\text {cryst }}\right)$; (6) metals occurring as, or in sulfides; and (7) the remaining metals not extracted in the preceding steps, referred to as the silicate or resistate phase. A step for the extraction of metals associated with organic material is sometimes included early in the sequence.

The partitioning of metals in four acid-generating mine wastes was investigated using sequential extractions. Concurrently, the wastes were mineralogically characterized by X-ray diffraction (XRD). Extractions were conducted on composite samples collected from the surface of waste dumps of the May Day and Yukon mines in the upper Animas Basin, near Silverton, Colorado, and the Sunday No. 2 and Venir mines near Leadville, Colorado. Sampling of the dumps and preparation of the bulk samples are described elsewhere (Smith et al. this volume). Extractions were first conducted on five size fractions derived from the $<2 \mathrm{~mm}$ fraction of the composites (table 1) and on several types of jarosite, a mineral commonly associated

1 U.S. Geological Survey, Denver, Colorado 
with pyritic mine wastes. The initial extractions were conducted to evaluate particle size effects as well as to establish the phase of extraction of jarosite, which was identified in all of the composites by XRD. For expediency, in these initial extractions metals were extracted from only five of the seven phases enumerated above. The ion-exchangeable and carbonate phases were not extracted and any metals associated with these phases are presumed to have been extracted with the $\mathrm{Fe}-\mathrm{MnOx}_{\mathrm{am}}$ phase. Aside from the water-soluble phase, the procedures used for the initial extractions are recommended by Griffioen and Broers 1993 (table 2).

Based on the results of the initial extractions, a second set of extractions was performed directly on the $<2 \mathrm{~mm}$ fraction of the composites and on two types of jarosite. All samples were pulverized to $<0.075 \mathrm{~mm}$. The number of phases extracted was expanded to include the ion-exchangeable and carbonate-associated metals and different procedures were used to extract the $\mathrm{FeOx}_{\text {crysl }}$, sulfide, and silicate phases (table 3). Finally, extractions of the first five phases (water-soluble through $\mathrm{FeOx}_{\text {crys }}$ ) were applied to samples of anglesite $\left(\mathrm{PbSO}_{4}\right)$ and cerussite $\left(\mathrm{PbCO}_{3}\right), \mathrm{Pb}$ minerals identified in specially prepared mineral separates of the wastes in detailed XRD studies (Sutley and Desborough, this volume).

\section{METHODS}

\section{Extractions of Varying Size Fractions and Jarosites}

Initially, to evaluate particle size effects, five phases were extracted from five size fractions (table 1) of each mine waste composite using the procedures in table 2. To determine the phase of extraction of jarosite, the same procedures were applied to samples of potassium, hydronium, and lead jarosite. The size fractions were obtained by sieving the bulk $<2 \mathrm{~mm}$ fraction of the composites through nested stainless steel sieves. The particle size of the jarosite samples was estimated to be $<0.18 \mathrm{~mm}$. Following each procedure, the extraction solution was separated from the sample residue by high speed $(12,500 \mathrm{rpm})$, temperature-controlled (20$25^{\circ} \mathrm{C}$ ) centrifugation and the extraction solution was filtered through a $0.45 \mu \mathrm{m}$ cellulose membrane syringe filter. The extract solutions were analyzed for metals by inductively coupled plasma-atomic emission spectrometry (ICP-AES) or by atomic absorption spectrophotometry (AAS).

\section{Seven-step Extraction Procedure}

Following the above initial extractions, the seven-step extraction procedure in table 3 was performed on splits of the $<2 \mathrm{~mm}$ fraction of the composites and on samples of potassium and lead jarosite. In addition, steps 1 through 5 were applied to samples of anglesite and cerussite. For these extractions, the samples were finely ground to $<0.075 \mathrm{~mm}$ in a miniature grinding mill or with a mortar and pestle. Separation of the sample residue from the extract solution was by centrifugation, as above. To assist in this separation and preclude further separation by filtration, pure silica gel was added to the sample prior to extraction of the initial $\left(\mathrm{H}_{2} \mathrm{O}\right.$ soluble) phase. The use of silica gel is permitted if analysis of the extract solutions for $\mathrm{Si}$ is not requisite. The extract solutions were analyzed for metal content by ICP-AES or AAS.

Table 1 Size fractions of composites and weight percent of total composite weight

\begin{tabular}{llll}
\hline Fraction & Range of particle size & $\begin{array}{l}\text { Weight percent } \\
\text { of Composite }\end{array}$ & $\begin{array}{l}\text { Weight percent } \\
\text { of Composite }\end{array}$ \\
\hline & & May Day & Yukon \\
1 & $<2 \mathrm{~mm}>0.425 \mathrm{~mm}$ & 62.45 & 55.40 \\
3 & $<0.425 \mathrm{~mm}>0.125 \mathrm{~mm}$ & 21.22 & 27.31 \\
4 & $<0.125 \mathrm{~mm}>0.075 \mathrm{~mm}$ & 8.37 & 8.95 \\
5 & $<0.075 \mathrm{~mm}>0.043 \mathrm{~mm}$ & 7.10 & 7.57 \\
& $<0.043 \mathrm{~mm}$ & 0.86 & 0.77 \\
1 & & & \\
2 & $<2 \mathrm{~mm}>0.425 \mathrm{~mm}$ & 63.50 & Venir \\
3 & $<0.425 \mathrm{~mm}>0.125 \mathrm{~mm}$ & 22.73 & 55.08 \\
4 & $<0.125 \mathrm{~mm}>0.075 \mathrm{~mm}$ & 9.04 & 25.74 \\
5 & $<0.075 \mathrm{~mm}>0.043 \mathrm{~mm}$ & 4.40 & 12.42 \\
\hline
\end{tabular}


Table 2 Five-procedure sequential extraction applied to five size fractions of mine waste composites and samples of jarosite (steps 2-5 are recommended by Griffioen and Broers,1993)

\begin{tabular}{|c|c|}
\hline Phase & Description of Procedure \\
\hline Water-soluble & $\begin{array}{l}\text { 1. One gram of sample is extracted with } 20 \mathrm{ml} \text { deionized water in a } 50 \mathrm{ml} \text { centrifuge } \\
\text { tube for two hours in a horizontal, reciprocating shaker, at ambient temperature. }\end{array}$ \\
\hline $\mathrm{Fe}-\mathrm{MnO} \mathrm{x}_{\mathrm{am}}$ & $\begin{array}{l}\text { 2. The residue from no. } 1 \text { is extracted with } 20 \mathrm{ml} \text { of } 0.25 \mathrm{M} \text { hydroxylamine } \\
\text { hydrochloride in } 0.25 \mathrm{M} \mathrm{HCl} \text { for } 30 \text { minutes in a water bath, at } 50^{\circ} \mathrm{C} \text { (Chao and Zhou } \\
\text { 1983). }\end{array}$ \\
\hline $\mathrm{FeOx}_{\text {cryst }}$ & $\begin{array}{l}\text { 3. The residue from no. } 2 \text { is extracted with } 40 \mathrm{ml} \text { of a solution that is } 0.2 \mathrm{M} \text { in } \\
\text { ammonium oxalate and oxalic acid and } 0.1 \mathrm{M} \text { in ascorbic acid for two hours in a } \\
\text { water bath, at } 94^{\circ} \mathrm{C} \text {. }\end{array}$ \\
\hline Silicate & $\begin{array}{l}\text { 4. The residue from no. } 3 \text { is shaken for eight hours with } 30 \mathrm{ml} \text { of } 10 \mathrm{M} \mathrm{HF} \text { to which is } \\
\text { then added } 5 \mathrm{~g} \text { of boric acid and the sample is shaken for another } 8 \text { hours. }\end{array}$ \\
\hline Sulfide & $\begin{array}{l}\text { 5. The residue from no. } 4 \text { is shaken for two hours with } 10 \mathrm{ml} \text { concentrated } \mathrm{HNO}_{3} \text {. } \\
\text { Prior to centrifugation, } 15 \mathrm{ml} \text { of deionized water are added (Lord 1982). }\end{array}$ \\
\hline
\end{tabular}

Table 3 Seven-procedure sequential extraction applied to the $<2 \mathrm{~mm}$ fraction of the mine waste composites and samples of jarosite

\begin{tabular}{|c|c|}
\hline Phase & Description of Procedure \\
\hline Water-soluble & $\begin{array}{l}\text { 1. Same as for } 5 \text {-procedure extraction except } 0.25 \mathrm{~g} \text { of sample, with } 0.25 \mathrm{~g} \text { of silica } \\
\text { gel added, is extracted with } 25 \mathrm{ml} \text { of water. }\end{array}$ \\
\hline Ion-exchangeable & $\begin{array}{l}\text { 2. The residue from no. } 1 \text { is extracted with } 25 \mathrm{ml}-1 \mathrm{M} \text { sodium acetate for one hour in a } \\
\text { horizontal reciprocating shaker, at ambient temperature. }\end{array}$ \\
\hline Carbonate & $\begin{array}{l}\text { 3. The residue from no. } 2 \text { is extracted in a shaker for two hours with } 25 \mathrm{ml} 1 \mathrm{M} \\
\text { sodiun acetate buffered to } \mathrm{pH} 5 \text { with acetic acid. }\end{array}$ \\
\hline $\mathrm{Fe}-\mathrm{MnOx}_{\mathrm{am}}$ & $\begin{array}{l}\text { 4. The residue from no. } 1 \text { is extracted with } 25 \mathrm{ml} \text { of } 0.25 \mathrm{M} \text { hydroxylamine } \\
\text { hydrochloride in } 0.25 \mathrm{M} \mathrm{HCl} \text { for } 30 \text { minutes in a water bath, at } 50^{\circ} \mathrm{C} \text { (Chao and Zhou } \\
\text { 1983). }\end{array}$ \\
\hline $\mathrm{FeOx}_{\text {cryst }}$ & $\begin{array}{l}\text { 5. The residue from no. } 4 \text { is extracted with } 25 \mathrm{ml} 4 \mathrm{M} \mathrm{HCl} \text { for } 30 \text { minutes in a water } \\
\text { bath at } 94^{\circ} \mathrm{C} \text {. }\end{array}$ \\
\hline Sulfide & $\begin{array}{l}\text { 6. Two grams of sodium chlorate are added to the residue from no. } 5 \text {, followed by } \\
\text { careful addition of } 10 \mathrm{ml} \text { concentrated } \mathrm{HCl} \text {. After } 45 \text { minutes the aqueous phase is } \\
\text { separated and diluted to } 25 \mathrm{ml} \text { with deionized water. The residue is extracted for } 40 \\
\text { minutes with } 25 \mathrm{ml} 4 \mathrm{M} \mathrm{HNO}_{3} \text { in a boiling water bath. The two extracts.are analyzed } \\
\text { separately and the results combined. (Chao and Sanzolone } 1977 \text { ) }\end{array}$ \\
\hline Silicate & $\begin{array}{l}\text { 7. The residue from no. } 6 \text { is transferred to a Teflon beaker and is digested with } 10 \mathrm{ml} \text {, } \\
\text { of each, concentrated } \mathrm{HNO}_{3}, \mathrm{HClO}_{4} \text {, and } \mathrm{HF} \text { at } 220^{\circ} \mathrm{C} \text {, to a moist bead. The moist } \\
\text { bead is taken up in } 25 \mathrm{ml} 4 \mathrm{M} \mathrm{HCl} \text { at } 100^{\circ} \mathrm{C} \text { for } 30 \text { minutes. The final volume is } \\
\text { adjusted to } 25 \mathrm{ml} \text { with deionized water. }\end{array}$ \\
\hline
\end{tabular}

\section{RESULTS AND DISCUSSION \\ Mineralogical Effects}

Differences in mineralogical composition influence selection of procedures commonly used for extraction of metals from phases of soils and sediments when they are applied to extraction of mine wastes. For example, the composites from the May Day, Yukon, Sunday No. 2, and Venir dumps were all determined by XRD to contain jarosite, a mineral of the general formula $\mathrm{AFe}_{3}\left(\mathrm{SO}_{4}\right)_{2}(\mathrm{OH})_{6}$. The " $\mathrm{A}$ " position is occupied by any of a number of cations, most often $\mathrm{K}^{+}, \mathrm{Na}^{+}, \mathrm{H}_{3} \mathrm{O}^{+}$, and $\mathrm{Pb}^{2+}$. In this study, several types of jarosite were sequentially extracted using the procedures recommended by Griffioen and Broers 1993 for extraction of soils and sediments. These include a solution of ammonium oxalate, oxalic acid, and ascorbic acid for extraction of the $\mathrm{FeOx}$ cryst phase, $\mathrm{HF}$ and $\mathrm{H}_{3} \mathrm{BO}_{3}$ for extraction of the silicate phase, and $\mathrm{HNO}_{3}$ to extract the sulfide phase (table 2). The results for $\mathrm{Fe}$ in figure 1 show that three types of jarosite (potassium, hydronium and lead) are partially extracted by the solution used to extract the $\mathrm{FeOx}_{\text {crys }}$ phase but are mostly extracted by the solution used to extract the residual or silicate phase. On the other hand, based on the $\mathrm{Fe}, \mathrm{K}$ and $\mathrm{Pb}$ results shown in figure $2, \mathrm{~K}$ - and $\mathrm{Pb}$-jarosite are almost totally extracted by hot $4 \mathrm{M} \mathrm{HCl}$. The use of $\mathrm{HCl}$ 


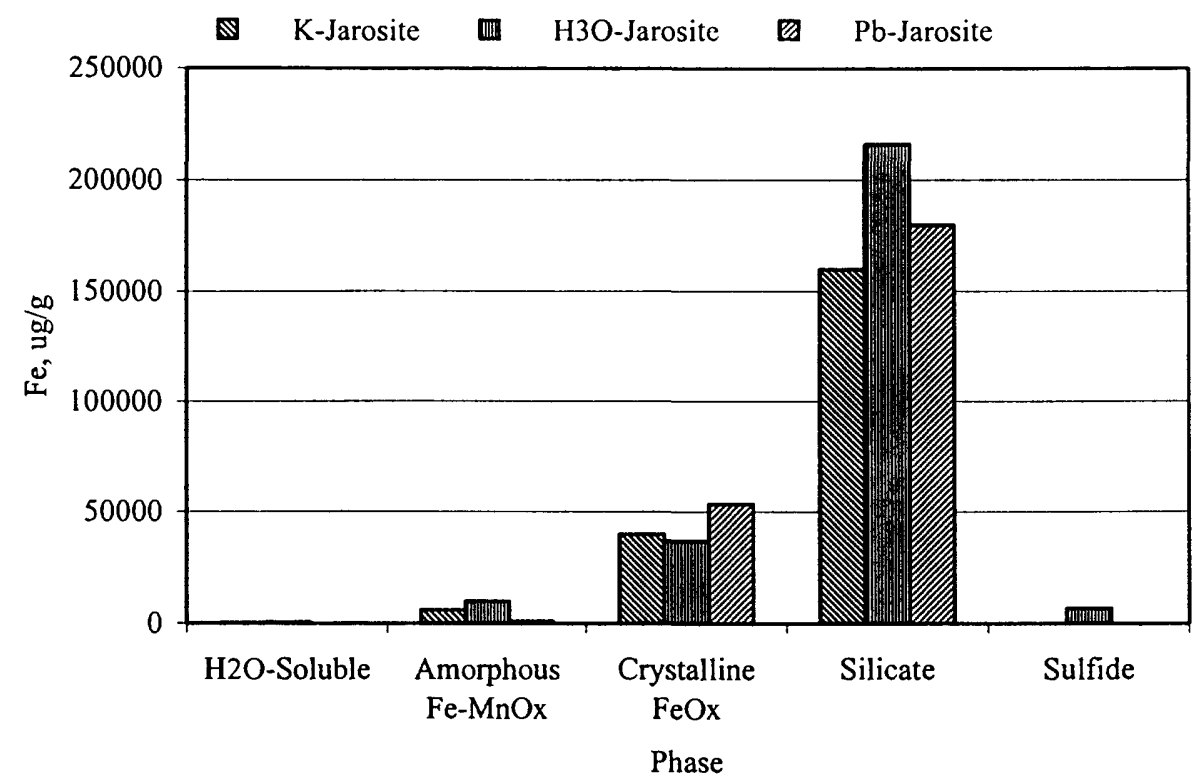

Figure $1 \mathrm{Fe}$ in five operationally-defined phases extracted from three types of jarosite following the procedures in table 2

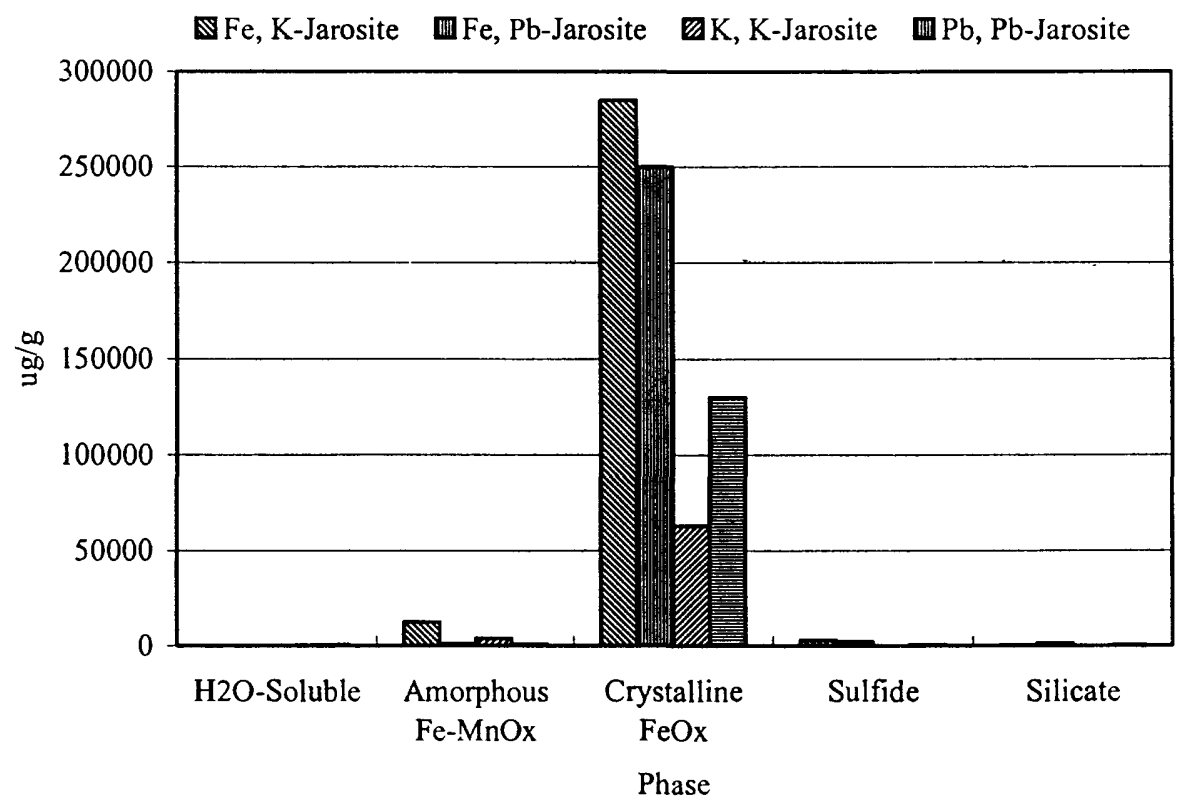

Figure $2 \mathrm{Fe}$ and $\mathrm{K}$ in five operationally-defined phases of $\mathrm{K}$-jarosite and $\mathrm{Fe}$ and $\mathrm{Pb}$ in five operationally-defined phases of $\mathrm{Pb}$-jarosite extracted using procedures described in table 3 


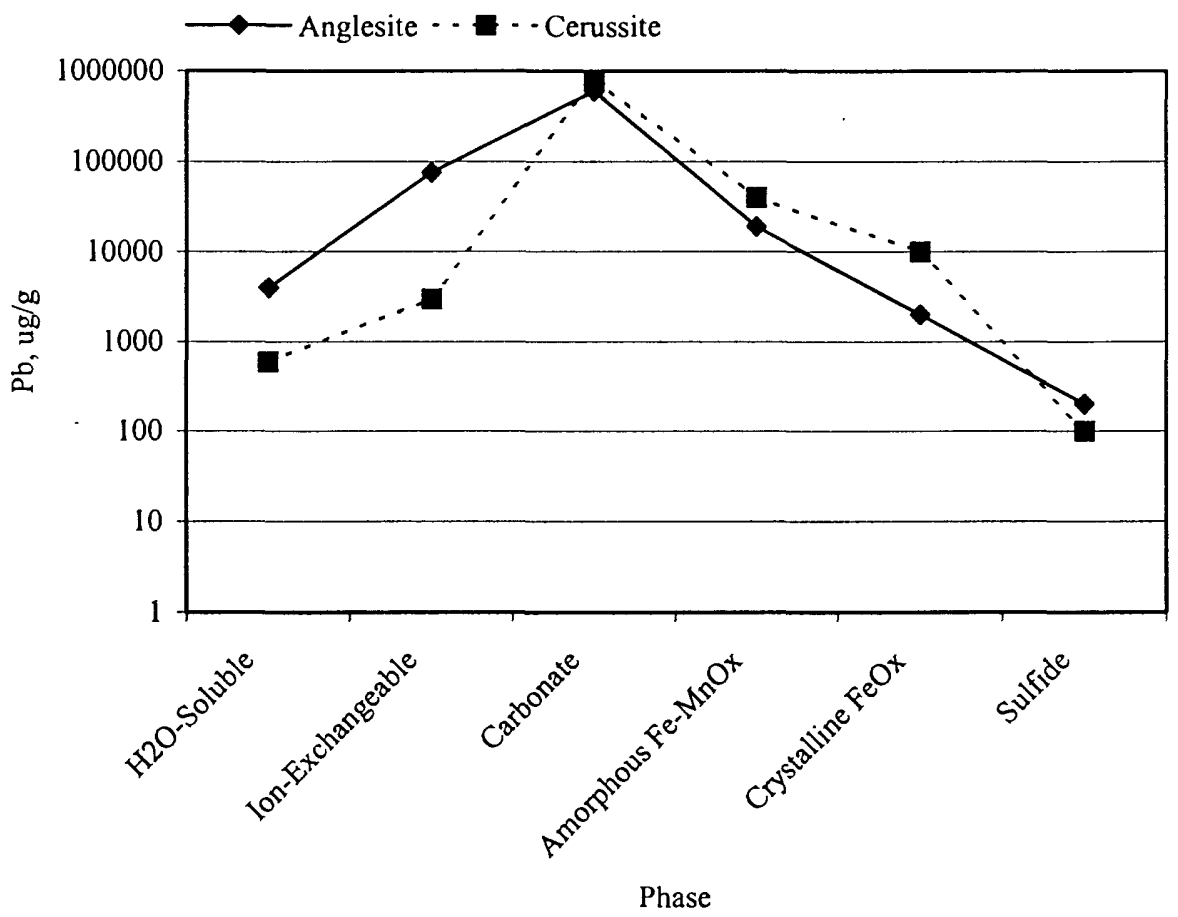

Figure $3 \mathrm{~Pb}$ in six operationally-defined phases extracted from anglesite and cerussite

of varying concentrations for extracting different crystalline Fe-oxide minerals, and its limitations are noted by Chao 1984 . Because of its effectiveness for extracting jarosite almost completely with the.FeOx cryst $_{\text {phase, }}$ the use of $\mathrm{HCl}$ is preferred for extractions of these mine wastes.

Figure 3 shows the results for $\mathrm{Pb}$ from the sequential extraction of anglesite, $\mathrm{PbSO}_{4}$, and cerussite, $\mathrm{PbCO}_{3}$. The results indicate that extraction of these minerals from mine wastes can be expected to begin with extraction of the water-soluble phase and probably concludes with extraction of the FeOx $\mathrm{x}_{\text {cryst }}$ phase. The results show that anglesite is more water soluble than cerussite.

The Effect of Particle Size

The extraction of metals varies with particle size but not necessarily systematically. In general, the concentrations of water-soluble $\mathrm{Fe}, \mathrm{Pb}, \mathrm{Zn}$ and $\mathrm{Cu}$ increase with decreasing particle size for all the mine waste composites, although increases may be minor. This is shown for the May Day composite in figure 4. The concentration of metals extracted with the Fe-MnOx $\mathrm{am}_{\text {am }}$ phe also increases with decreasing particle size. There is an inverse correlation of $\mathrm{Fe}$ and $\mathrm{Zn}$ in the $\mathrm{FeOx}_{\text {cryst }}$ phase and the size fractions of the Yukon composite (figure 5), while $\mathrm{Pb}$ is shown to increase in the mid-range size fractions and then decrease in concentration with decreasing particle size. In the sulfide phase, there is an overall positive correlation between particle size and the concentration of $\mathrm{Fe}, \mathrm{Pb}, \mathrm{Zn}$ and $\mathrm{Cu}$ in the Yukon composite (figure 6). A clear exception is the amount of $\mathrm{Fe}$ extracted from the fraction of largest particle size. The relatively low concentration of Fe extracted in the $<2 \mathrm{~mm}>0.425 \mathrm{~mm}$ fraction is attributed to incomplete dissolution of larger pyrite crystals under the conditions of extraction with nitric acid (Lord, 1982). The distribution of metals in the $\mathrm{FeOx}_{\text {cryst }}$ and sulfide phases of the Yukon composite (figures 5 and 6) is attributed to 
oxidation of pyrite by weathering with decreasing particle size and the resulting increase in the amount of oxides in the smaller size fractions.

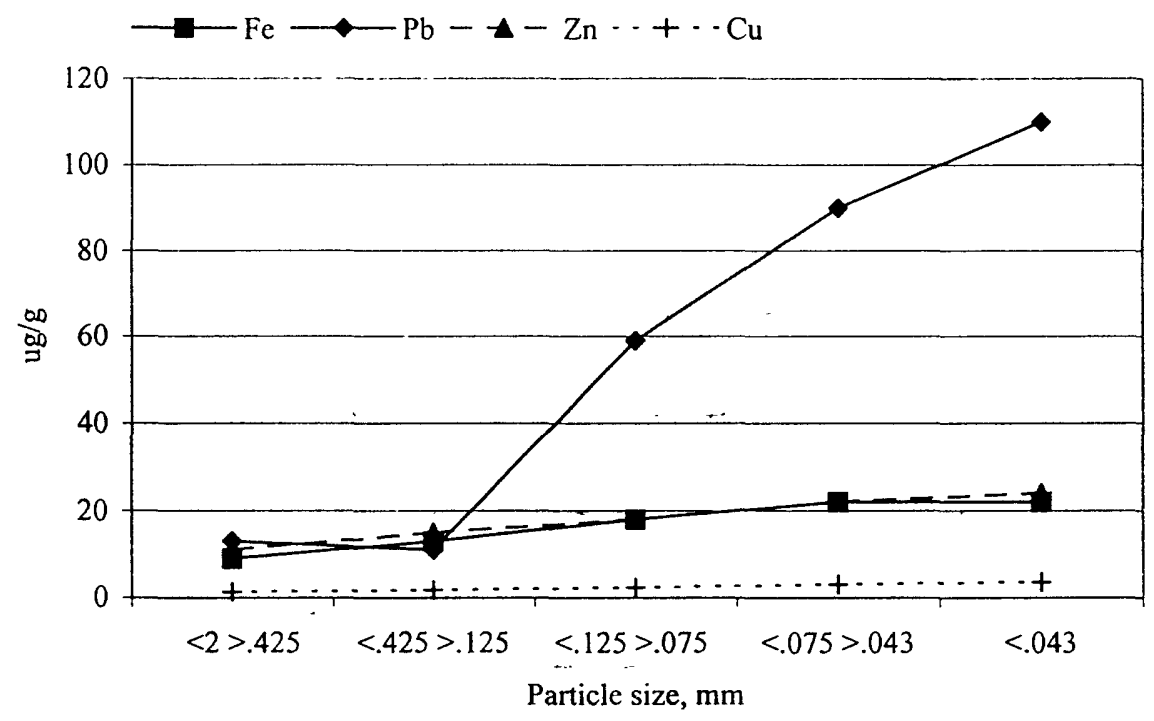

Figure 4 The effect of particle size on extraction of water-soluble metals, May Day composite

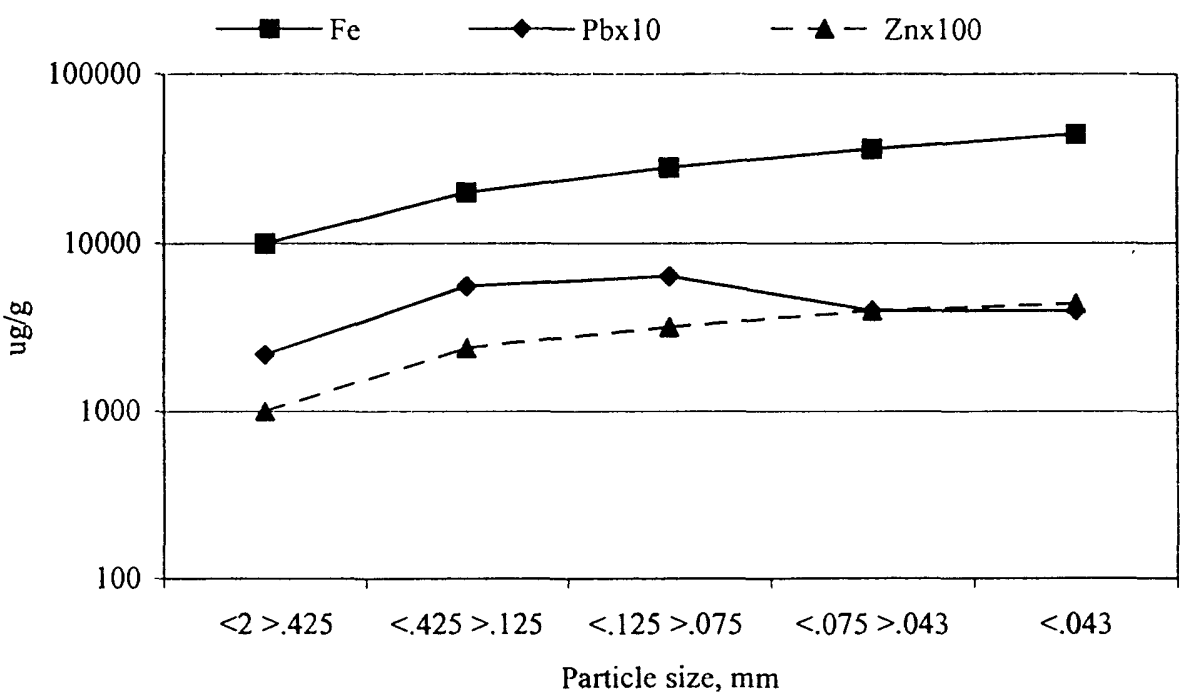

Figure 5 The effect of particle size on extraction of metals in the $\mathrm{FeOx}_{\text {cryst }}$ phase, Yukon composite 


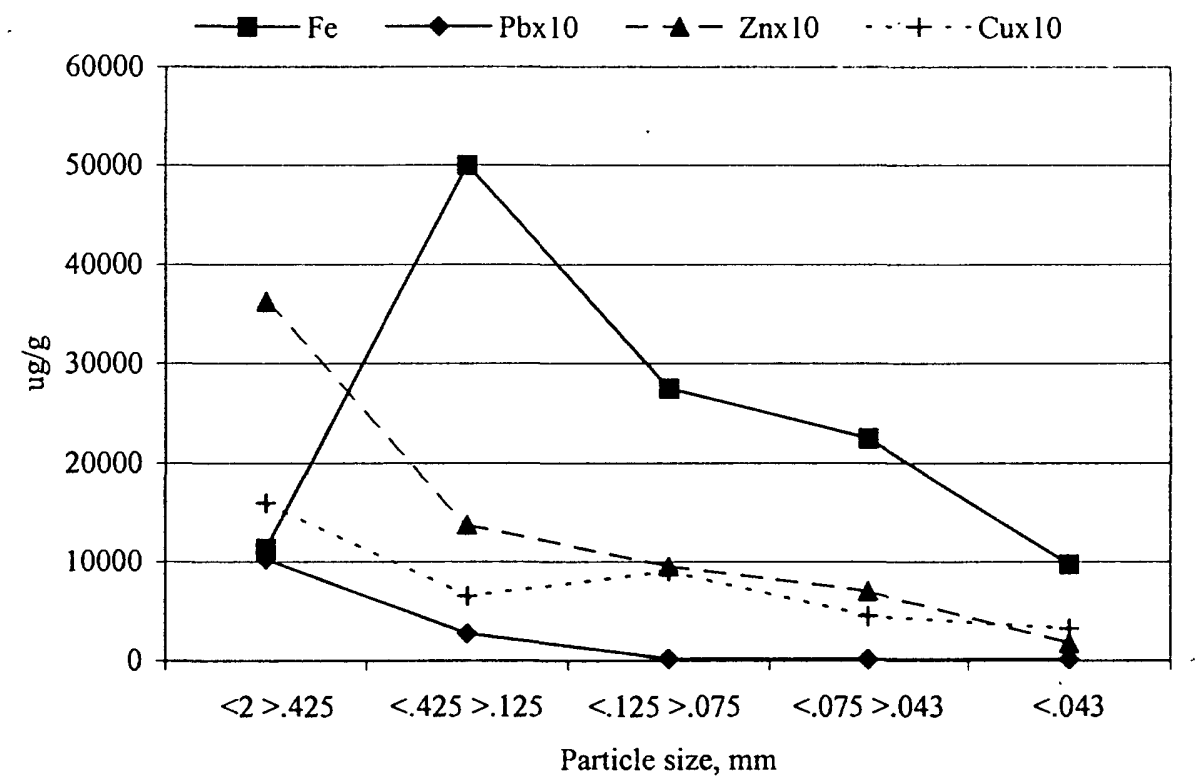

Figure 6 The effect of particle size on extraction of metals in the sulfide phase, Yukon composite

Partitioning of Metals in the $<2 \mathrm{~mm}$ Fraction of Mine Wastes

Results from the extractions of the $<2 \mathrm{~mm}$ fraction of the composites are shown in figures $7-10$. Zinc and $\mathrm{Cu}$ are more favorably partitioned in the $\mathrm{FeOx}_{\text {cryst }}$ and sulfide phases of the composites while $\mathrm{Pb}$ appears to be more favorably partitioned in the $\mathrm{Fe}_{\mathrm{am}}$ and $\mathrm{FeOx}_{\text {cryst }}$ phases. Lead minerals identified in the composites by $\mathrm{XRD}$ include anglesite, cerussite, and galena. As noted above, anglesite and cerussite are extracted over five phases and galena $(\mathrm{PbS})$ is soluble in $\mathrm{HCl}$, the extract solution for $\mathrm{FeOx}_{\text {cryst }}$. Iron is strongly partitioned into the $\mathrm{FeOx}_{\text {cryst }}$ phase of the May Day composite and the sulfide phase of the Yukon composite (figures 7 and 8). Differences between $\mathrm{Fe}$ in the $\mathrm{FeOx}_{\text {cryst }}$ and sulfide phases are less pronounced in the Sunday No.2 and Venir composites (figures 9 and 10 ). From figures $7-10$, it is clear that in all the composites, $\mathrm{K}$ occurs almost exclusively in the silicate, or resistate phase, most likely in muscovite.

Semi-quantitative XRD analysis (Sutley and Desborough, this publication) shows the amount of jarosite in the four composites ranges from about 5 to $8 \%$. The amount of Fe extracted in the FeOx cryst $_{\text {phase (figures }}$ 7-10) exceeds the amount of Fe accounted for by the XRD-jarosite in each composite. Host minerals of Fe not accounted for by jarosite are uncertain. Similarly, the occurrence of $\mathrm{Fe}$ in the sulfide phase of the Yukon, Sunday No.2 and Venir composites (figures 8, 9 and 10) exceeds the amount accounted for by XRD pyrite. The remaining sulfide-Fe is unaccounted for mineralogically. The amount of $\mathrm{Fe}$ extracted from the sulfide phase of the May Day composite (figure 7) equates to $<0.5 \%$ pyrite, which was not detected by $\mathrm{XRD}$. The occurrence of trace amounts of sphalerite, $\mathrm{ZnS}$, in the May Day and Sunday \#2 composites is reflected by $\mathrm{Zn}$ extracted with the sulfide phase (figures 7 and 9). Lead occurring in finely crystalline galena $(<0.050 \mathrm{~mm})$, detected in a heavy mineral concentrate of the Sunday No.2 composite, was mostly extracted by $4 \mathrm{M} \mathrm{HCl}$ with the $\mathrm{FeOx}_{\text {cryst }}$ phase. Extraction of anglesite, $\mathrm{PbSO}_{4}$, found to be present in heavy mineral concentrates 


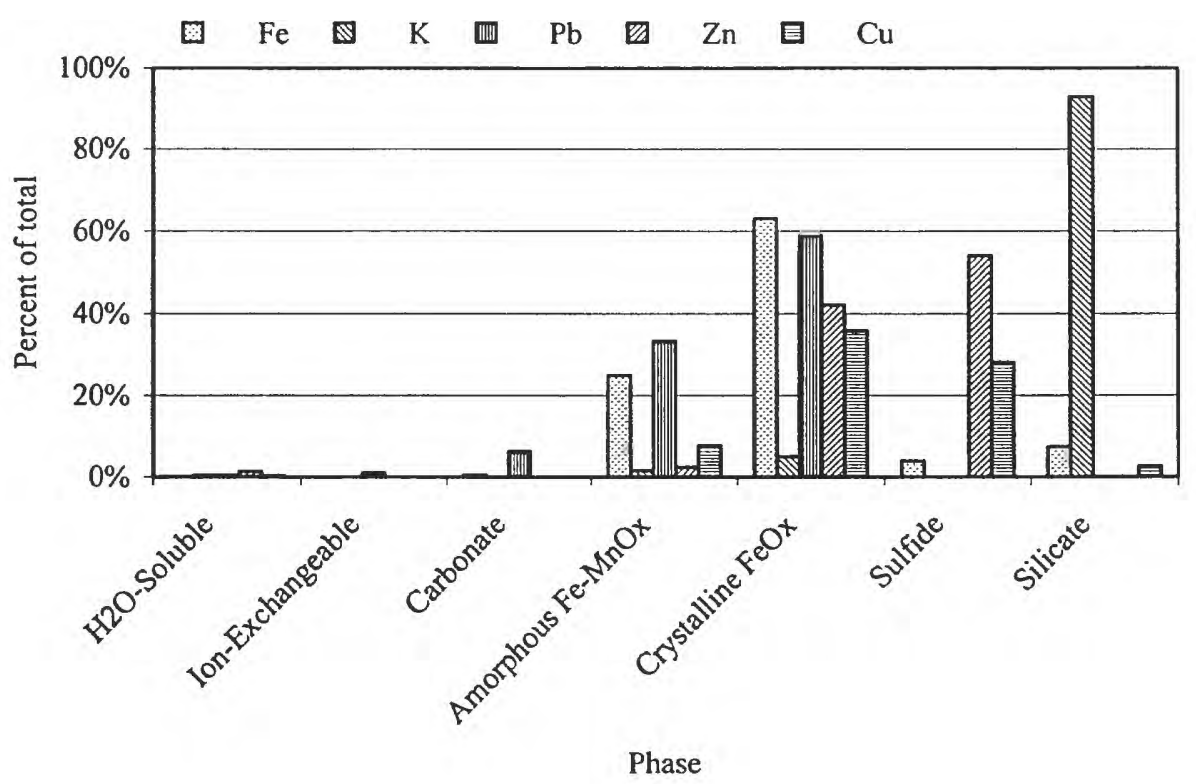

Figure 7 The extraction of metals in seven phases of the $<2 \mathrm{~mm}$ size fraction, May Day composite

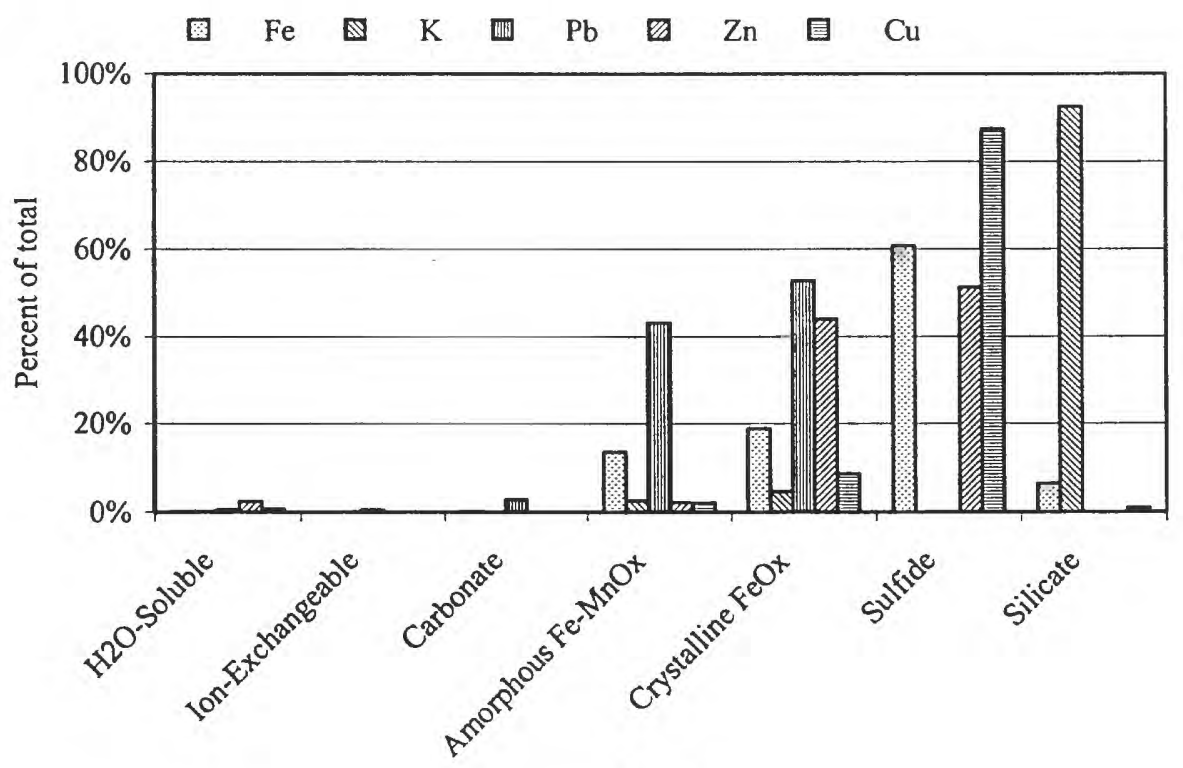

Phase

Figure 8 The extraction of metals in seven phases of the $<2 \mathrm{~mm}$ size fraction, Yukon composite 


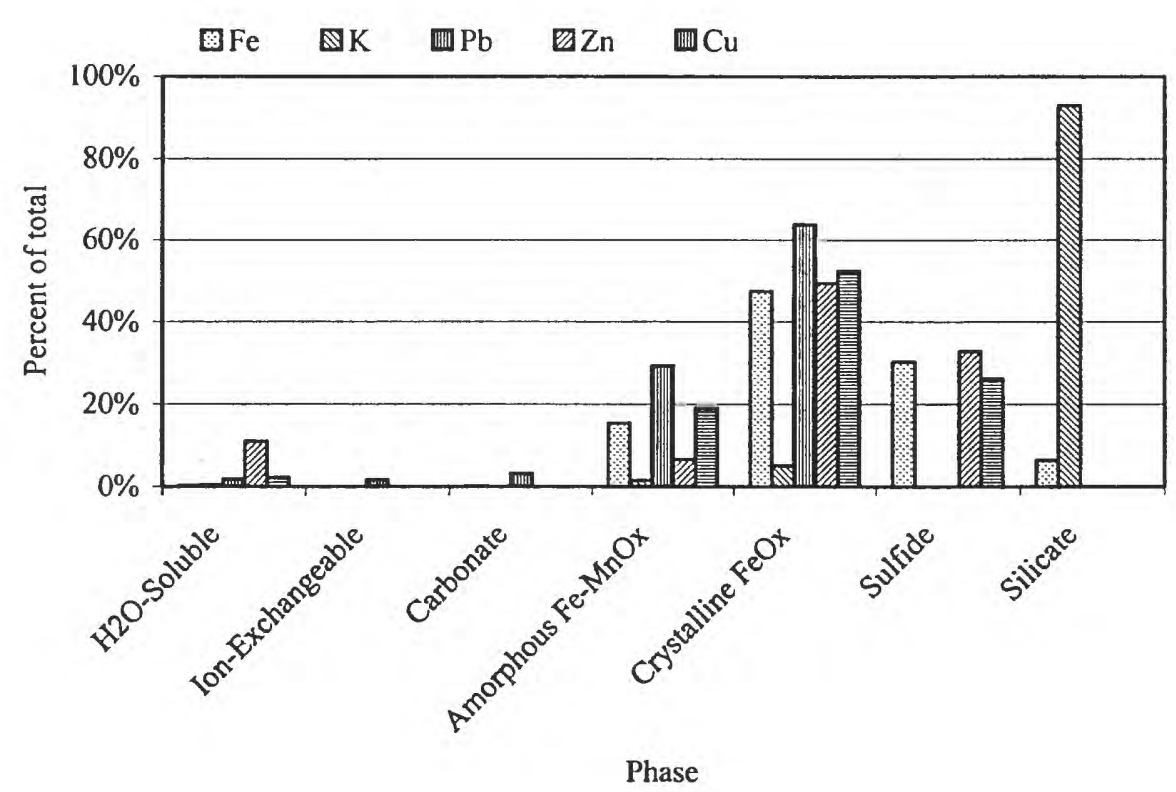

Figure 9 The extraction of metals in seven phases of the $<2 \mathrm{~mm}$ size fraction, Sunday No.2 composite

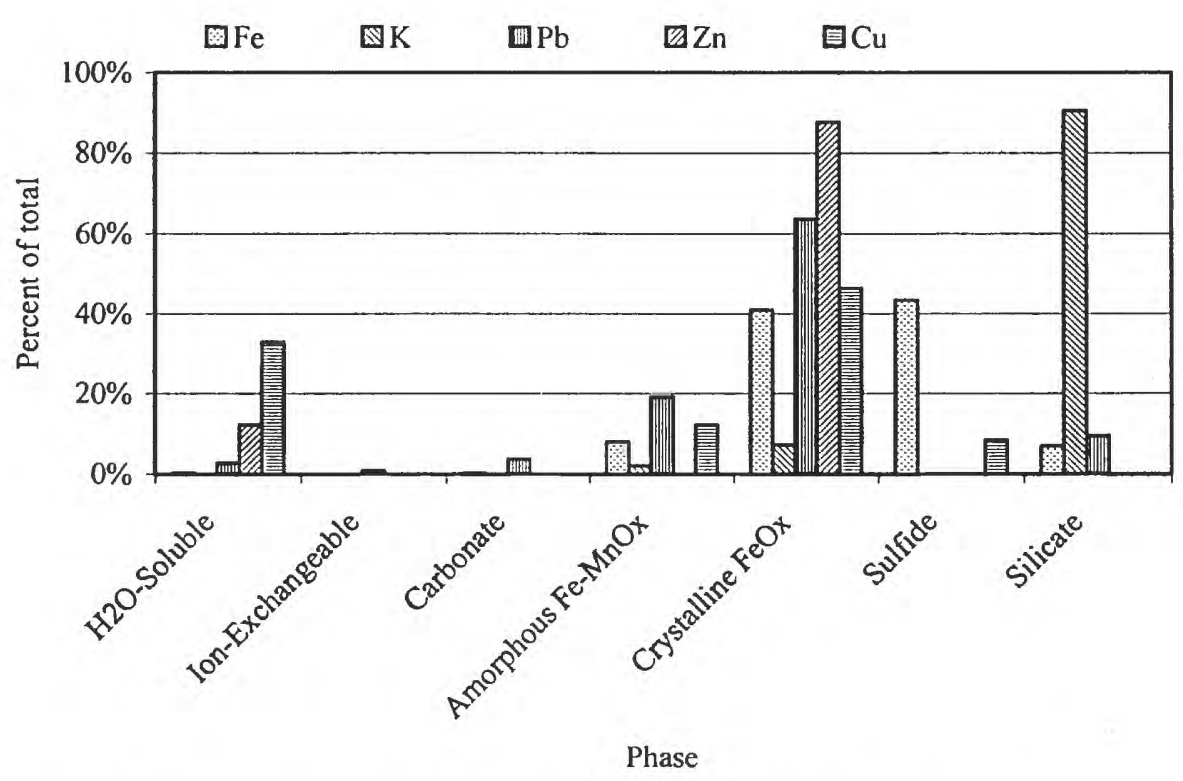

Figure 10 The extraction of metals in seven phases of the $<2 \mathrm{~mm}$ size fraction, Venir composite 
of the May Day and Venir composites, and cerussite, $\mathrm{PbCO}_{3}$, in the Sunday No.2 composite probably spans extraction of the water-soluble through the $\mathrm{FeOx}_{\text {cryst }}$ phases, suggested by results of extractions of the pure minerals (figure 6). The amount of $\mathrm{K}$ extracted from the composites (figures 7-10), almost exclusively in the silicate phase, is not totally accounted for by muscovite or feldspar identified by XRD.

Mineralogical analysis of the May Day, Yukon, Sunday No.2 and Venir composites indicates that about $40 \%$ of each is amorphous material (Sutley and Desborough, this publication). Comparing the chemical composition derived from XRD mineralogy with the composition derived by other methods, including X-ray fluorescence (XRF) and analysis by ICP-AES and AAS following total digestion, shows that mineralogy does not account for significant amounts of $\mathrm{Si}, \mathrm{K}, \mathrm{Al}$, and $\mathrm{Fe}$. This implies that the unaccounted for portions of these metals reside in an amorphous phase. The results for the extraction of $\mathrm{K}$ shown in figures 7-10 suggest that it resides principally in an amorphous silicate phase.

\section{Extraction Results and the Mobility and Availability of Metals}

The progressively increasing rigor or strength of the procedures in sequential extractions provides a means for evaluating the mobility of metals in mine wastes and their availability to the environment. Defining as mobile, or potentially mobile, the metals extracted with the water-soluble through the $\mathrm{Fe}_{\mathrm{am}}$ phases, table 4 shows the amount of mobile, $\mathrm{Pb}, \mathrm{Zn}$, and $\mathrm{Cu}$ in each composite. The sum of mobile $\mathrm{Pb}, \mathrm{Zn}$ and $\mathrm{Cu}$ is greatest for the Sunday No. 2 followed closely by the May. Day composite (table 4). However, table 4 shows $40 \%$ of the sum of total $\mathrm{Pb}, \mathrm{Zn}$ and $\mathrm{Cu}$ in the May Day composite is accounted for by the mobile or potentially mobile form of these metals, highest of all the composites. At the concentrations in which these occur, $\mathrm{Pb}$ can be considered the most problematic. Ribet et al. 1995 make the case that reductive dissolution of weathered mine tailings by-organic covers intended to remediate the tailings may release metals into the environment. They equate the reducible phase of the tailings with the component extracted by $2 \mathrm{M}$ hydroxylamine hydrochloride $\left(\mathrm{NH}_{2} \mathrm{OH} \cdot \mathrm{HCl}\right)$ in $25 \%(\mathrm{v} / \mathrm{v})$ acetic acid (HOAc), which would encompass the $\mathrm{Fe}_{\mathrm{am}}$ phase extracted in this study and likely extend into the $\mathrm{FeOx}_{\text {cryst }}$ phase. The mobilization of metals by action of decaying organic matter in the mine wastes studied here is feasible. Likewise, the mobilization under natural conditions of metals associated with the ion-exchangeable and carbonate phases is feasible.

Table 4 Total metals $(\Sigma)$, metals in mobile phases, and sum of mobile ( $\Sigma$ Mobile) metals in $<2 \mathrm{~mm}$ composites (n.d. means not detected)

\begin{tabular}{|c|c|c|c|c|}
\hline 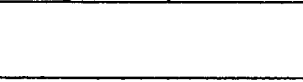 & $\begin{array}{l}\text { May Day } \\
(\mu \mathrm{g} / \mathrm{g})\end{array}$ & $\begin{array}{l}\text { Yukon } \\
(\mu \mathrm{g} / \mathrm{g})\end{array}$ & $\begin{array}{l}\text { Sunday No.2 } \\
(\mu \mathrm{g} / \mathrm{g})\end{array}$ & $\begin{array}{l}\text { Venir } \\
(\mu \mathrm{g} / \mathrm{g})\end{array}$ \\
\hline$\Sigma \mathrm{Pb}$ & 5092 & 2081 & 7824 & 1569 \\
\hline $\mathrm{H}_{2} \mathrm{O}$-Soluble & 22 & 11 & 144 & 44 \\
\hline Ion-Exchangeable & 50 & 10 & 130 & 15 \\
\hline Carbonate & 320 & 60 & 250 & 60 \\
\hline Amorphous Fe-MnOx & 1700 & 900 & 2300 & 300 \\
\hline$\sum$ Mobile $\mathrm{Pb}$ & 2092 & 981 & 2824 & 419 \\
\hline$\Sigma \mathrm{Zn}$ & 1662 & 1363 & 607 & 228 \\
\hline $\mathrm{H}_{2} \mathrm{O}$-Soluble & 22 & 33 & 67 & 28 \\
\hline Ion-Exchangeable & n.d. & n.d. & n.d. & n.d. \\
\hline Carbonate & n.d. & n.d. & n.d. & n.d. \\
\hline Amorphous Fe-MnOx & 700 & 30 & 40 & n.d. \\
\hline$\Sigma$ Mobile $\mathrm{Zn}$ & 722 & 63 & 107 & 28 \\
\hline$\Sigma \mathrm{Cu}$ & 291 & 1040 & 305 & 237 \\
\hline $\mathrm{H}_{2} \mathrm{O}$-Soluble & 1.1 & 7.8 & 6.7 & 78 \\
\hline Ion-Exchangeable & n.d. & n.d. & n.d. & n.d. \\
\hline Carbonate & n.d. & n.d. & n.d. & n.d. \\
\hline Amorphous Fe-MnOx & 30 & 22 & 58 & 29 \\
\hline$\Sigma$ Mobile $\mathrm{Cu}$ & 31 & 30 & 65 & 107 \\
\hline
\end{tabular}

\section{CONCLUSION}

Sequential extractions can be used to determine the mode of occurrence of metals in mine wastes in the sense that with these extractions metals are partitioned into operationally defined phases. The extractability of 
metals in each phase varies with particle size, but not necessarily in a systematic manner. The mineralogical composition of the mine wastes influences selection of extraction procedures. Interpretation of extraction results is facilitated to a limited extent by XRD mineralogical analysis. Limitations are due primarily to the lack of specificity of the extraction procedures but also to the relatively high XRD detection limits and the presence of amorphous material in the wastes. The XRD-amorphous material appears to be extracted with the $\mathrm{FeOx}_{\text {cryst }}$ phase and the residual, or silicate phase. The increasing chemical strength of the steps in sequential extractions provides a means for evaluating the mobility and availability of metals in mine wastes. As a result, sequential extractions may be useful in studies addressing the impact of mining activity on the environment.

\section{ACKNOWLEDGEMENTS}

We thank the property owners and custodians for granting access to the properties, the USGS Mineral Resources Program for supporting this and related investigations, the members of the Mine Waste Characterization project for their help and encouragement, and the reviewers of this paper.

\section{REFERENCES}

Chao, T.T. 1984. Use of partial dissolution techniques in geochemical exploration. J. Geochem. Explor. 20:101-135.

Chao, T.T. and R.F. Sanzolone. 1977. Chemical dissolution of sulfide minerals. U.S. Geological Survey J. Res. 5:409-412

Chao, T.T. and Zhou, Liyi. 1983. Extraction techniques for the selective dissolution of amorphous iron oxides from soils and sediments. Soil Sci. Am . J. 47:225-232.

Griffioen, J. and H.P Broers. 1993. Characterization of sediment reactivity: the feasibility of sequential extraction techniques. TNO Institute of Applied Science, Delft, the Netherlands. Rep. OS 93-65A: 90p. plus 2 appendices.

Lord, C.J., III. 1982. A selective and precise method for pyrite determination in sedimentary materials. J. Sed. Petrol. 52:664-666.

Ribet, I., Ptacek, C.J., Blowes, D.W., and J.L. Jambor. 1995. The potential for metal release by reductive dissolution of weathered mine tailings. J Contam. Hydrol. 17:239-273.

Tessier, A., Campbell, P.G.C., and M. Bisson. 1979. Sequential extraction procedures for the speciation of particulate trace metals. Anal. Chem. 51:844-851. 


\title{
Natural Sources of Metals to Surface Waters in the Upper Animas River Watershed, Colorado
}

\author{
M. Alisa Mast ${ }^{1}$, Philip L. Verplanck ${ }^{2}$, Douglas B. Yager ${ }^{3}$, Winfield G. Wright ${ }^{4}$, and Dana J. Bove ${ }^{3}$
}

\begin{abstract}
The upper Animas River watershed is affected by metal-rich drainage from abandoned mines and by natural weathering of mineralized bedrock. To investigate the importance of natural metal sources, surface waters were sampled in a minimally mined but intensely altered area of the watershed. Water chemistry was strongly controlled by the degree of bedrock alteration. Propylitically altered rocks, which contain calcite, produced neutral waters with low metal concentrations, whereas quartz-sericite-pyrite alteration was characterized by acid-sulfate type waters with high metal concentrations. A mass-balance approach was used to estimate natural metal sources, which accounted for $56-90 \%$ of the dissolved metal load discharging from the study area.
\end{abstract}

\section{INTRODUCTION}

The upper Animas River watershed (UARW), located in the southern part of the Colorado mineral belt, was heavily mined during the late 1800's and early 1900's for gold, silver, zinc, and lead. Numerous prospects, draining mine adits, waste-rock piles, and mill tailings were left when mines were eventually abandoned. Some of these features have significantly affected the water quality and aquatic resources of the Animas River and its tributaries. Recently, local stakeholder groups and State and Federal agencies have been interested in remediating abandoned mine sites, with the goal of restoring aquatic ecosystems along some reaches of the river. In 1997, the U.S. Geological Survey (USGS) implemented the Abandoned Mine Lands Initiative (AMLI) to provide technical assistance in support of remediation of abandoned mine sites on publicly owned lands (Nimick and von Guerard, 1998).

One of the objectives of the AMLI is to estimate natural contributions of metals to surface waters prior to mining activities. Although drainage from abandoned mines can affect surface-water quality, natural weathering of altered and mineralized bedrock also may be an important source of metals to the UARW. Knowledge of premining water quality in mining-affected areas can help establish remediation goals for surface waters. This concept is particularly important in areas where current water-quality standards may be lower than naturally occurring metal concentrations (Runnells et al., 1992). Several different approaches for estimating natural metal contributions have been described in the literature including statistical methods, examination of historical data, geochemical modeling, and comparison with geologically similar but unmined areas (Runnells et al., 1992; Miller et al., 1995; Nordstrom et al., 1996; Runnells et al., 1998). Determination of natural contributions of metals in historical mining areas may be particularly challenging because premining water-quality data usually are not available for comparison. In addition, mineralized areas are most often disturbed by mining, thus making it difficult to separate mining-related from natural sources of metals.

\footnotetext{
${ }^{1}$ U.S. Geological Survey, Water Resources Division, Denver, Colorado.

${ }^{2}$ U.S. Geological Survey, Water Resources Division, Boulder, Colorado.

${ }^{3}$ U.S. Geological Survey, Geologic Division, Denver, Colorado.

${ }^{4}$ U.S. Geological Survey, Water Resources Division, Durango, Colorado.
} 


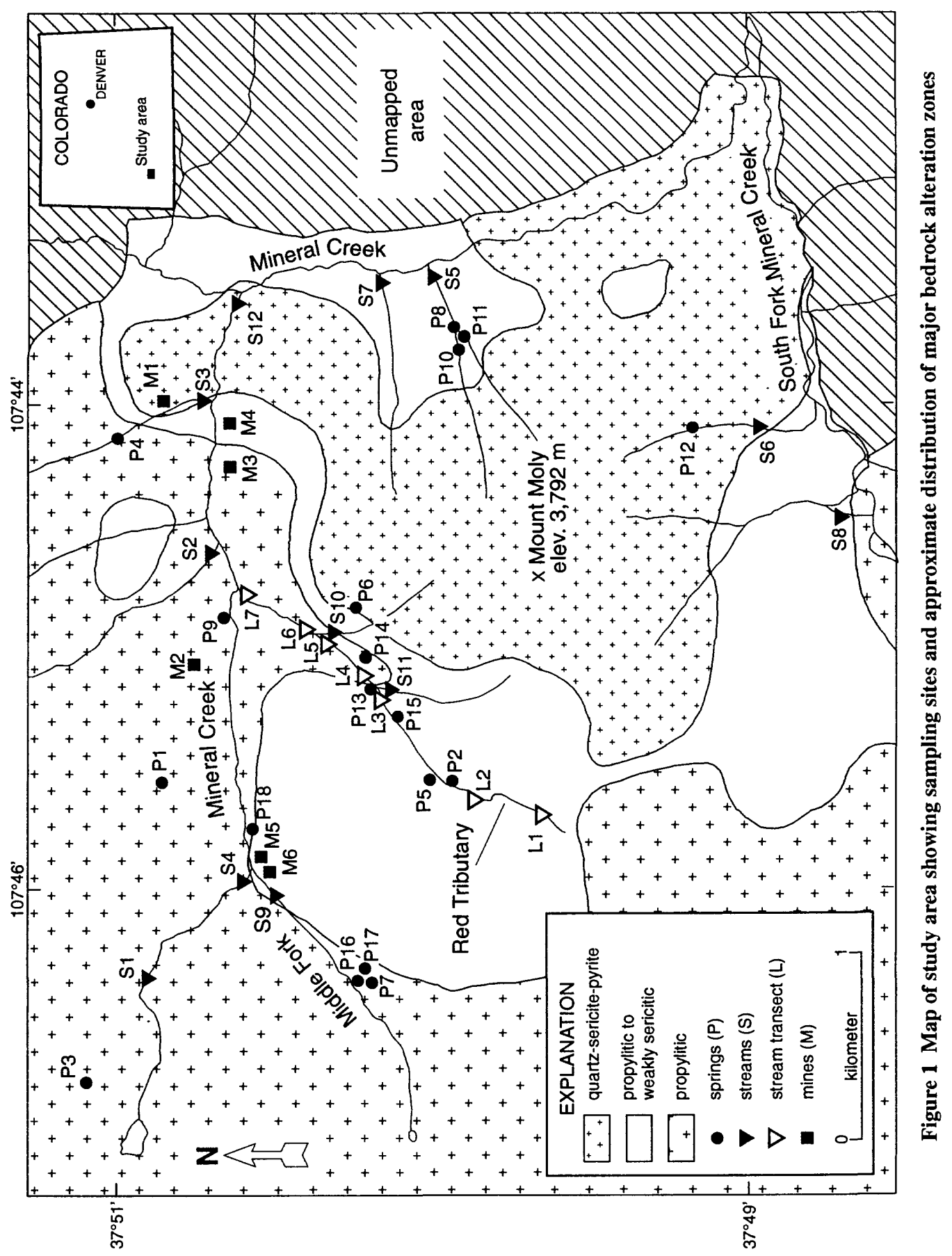


This investigation was conducted as part of the AMLI to identify and quantify metal inputs from natural weathering sources and focused on a largely unmined area of the UARW that is underlain by intensely altered bedrock. The specific objectives of the study were to: (1) characterize the chemistry of natural springs and streams in a subbasin of the UARW, (2) determine the relation between surface-water chemistry and the degree of bedrock alteration, and (3) estimate contributions of metals from natural weathering sources in the study area using a mass-balance approach. The results of this study will improve understanding of the natural processes controlling surface-water chemistry in a mineralized area and should provide information that will contribute towards establishing water-quality standards in the UARW.

\section{STUDY SITE DESCRIPTION}

The study area, located in the UARW in the San Juan Mountains of southwestern Colorado (Fig. 1), covers about $25 \mathrm{~km}^{2}$ of rugged mountainous terrain that ranges in elevation from 2,900 to 3,960 m. Included in the study area is the drainage of the Middle Fork Mineral Creek (MFMC) and the area surrounding Mount Moly, an informally named 3,792-m peak that has a distinct reddish color due to its intensely altered bedrock. Much of the study area lies above treeline $(3,475 \mathrm{~m}$ ) and slopes are covered by alpine tundra and extensive talus fields. Spruce-fir forest is prevalent at lower elevations. Annual precipitation is about $120 \mathrm{~cm}$, more than half of which accumulates in a seasonal snowpack that reaches several meters. Snowmelt is the major hydrologic event of the year; and most of the total annual streamflow typically occurs in May and June.

The geology of the study area has been mapped in detail by Ringrose (1982) and is summarized by Yager et al. (this volume). The area is primarily underlain by volcanic rocks related to the San Juan caldera complex of Tertiary age. The volcanic rocks consist of thick sequences of breccias, tuffs, and lavas of intermediate composition, which locally are intruded by stocks and sills of porphyritic monzonite (Ringrose, 1982). The primary mineralogy of the-unaltered lavas includes plagioclase, biotite, and hornblende and the monzonite porphyry consists of plagioclase, biotite, orthoclase, and quartz. Nearly all the volcanic rocks in the study area have undergone some degree of propylitic alteration, which is believed to be related to caldera collapse (Ringrose, 1982). The propylitically altered rocks are characterized by partial breakdown of primary minerals to chlorite, albite, epidote, and calcite with disseminated pyrite in the groundmass. Superimposed on the propylitic alteration is a zone of more intense hydrothermal alteration related to the monzonite intrusions. The most intensely altered area is centered on Mount Moly (Fig. 1) and is characterized by a mineral assemblage of quartz, sericite, and pyrite (QSP). The QSP zone grades outward into a propylitic to weakly sericitic zone (WS), which is characterized by metastable feldspars, sericite, pyrite, and occasionally chlorite. A more detailed description of the alteration zones in the study area can be found in Yager et al. (this volume).

The monzonite intrusive activity and associated hydrothermal alteration resulted in a low-grade $\mathrm{Mo}-\mathrm{Cu}$ porphyry under Mount Moly (Ringrose, 1982). Exploratory drilling of the porphyry molybdenite deposit occurred in the 1980's, but no economically feasible deposit was located. Associated mineralization includes stockwork quartz-molybdenite-pyrite veinlets near the zone of most intense alteration and polymetallic sulfide-bearing veins that are localized along fractures and faults on the periphery of the hydrothermal system (Ringrose, 1982). Common sulfide minerals associated with these veins include sphalerite and galena with lesser amounts of pyrite and tetrahedrite-tennantite (Ringrose, 1982). Abandoned mines in the study area primarily are located along polymetallic veins (Ringrose, 1982) several of which discharge metal-rich waters into the main channel of the MFMC.

\section{METHODS}

Forty-three stream, spring, and mine sites were sampled in the watershed of the MFMC and on the flanks of Mount Moly during summer base-flow conditions in 1995, 1997, and 1998. Samples for water-quality analyses were collected by pumping water directly from the stream with polyvinyl tubing, through a $0.45-\mu \mathrm{m}$ membrane filter, and into pre-cleaned polyethylene bottles. A filtered aliquot for major and trace-metal analysis was acidified to $\mathrm{pH}<2$ with concentrated ultrapure nitric acid. A filtered, unpreserved aliquot was collected for sulfate analysis, and an unfiltered aliquot was collected for alkalinity. Field measurements at each site included discharge, specific conductance, $\mathrm{pH}$, water temperature, and dissolved oxygen. Major- and tracemetal concentrations were determined in the acidified samples by inductively coupled plasma spectrometry. Alkalinity was determined by incremental titration on samples with $\mathrm{pH}>4.5$ within 12 hours of sample collection and sulfate was determined by a turbidimetric method. Speciation and mass-balance calculations were made with the computer programs PHREEQC (Parkhurst, 1995) and NETPATH (Plummer et al., 1994). 


\section{RESULTS AND DISCUSSION}

Water-Quality Characteristics

Water-quality data for streams and springs draining the MFMC watershed and the area surrounding Mount Moly are listed in Table 1 and sampling locations are shown in Figure 1. The main stem of the MFMC is affected by drainage from several mines (M1-M6) located along the main channel, whereas most of the tributary streams and springs in the study area are upgradient from, and thus unaffected by, mining. The chemistry of streams and springs unaffected by mining was variable; $\mathrm{pH}$ ranged from 2.70 to 8.02 and specific conductance ranged from 58 to $2,180 \mu \mathrm{S} / \mathrm{cm}$. Sites with neutral $\mathrm{pH}$ typically had calcium-bicarbonate-sulfate type waters, whereas the low-pH waters were dominated by aluminum, iron, and sulfate. Results from a subset of samples analyzed for ferrous iron (Fe[II]) indicate that iron .in the acidic waters largely was present as Fe(II). The predominant trace metals in the sampled waters were manganese, zinc, and copper, with the highest concentrations occurring in the acidic waters. Some of the highest concentrations were measured at a small spring (P10) on the east side of Mount Moly, which had copper and zinc concentrations of 370 and 580 $\mu \mathrm{g} / \mathrm{L}$, respectively. Although not listed in Table 1 , concentrations of cadmium, chromium, lead, molybdenum, and nickel were near analytical detection, even in the acidic waters. All of the sampled streams were well oxygenated, but many of the springs had low dissolved-oxygen concentrations. This may indicate that springs are fed by oxygen-depleted ground water discharging at the surface along faults or fractures.

On October 2, 1998, a synoptic sampling along the length of the Red Tributary, the major stream drainage adjacent to Mount Moly (Fig. 1), was conducted to measure downstream changes in stream chemistry in a naturally acidic stream. Significant changes were measured in the major- and trace-metal concentrations of the tributary along the $2.1-\mathrm{km}$ reach between $\mathrm{L1}$ and L7 (Table 1). At the head of the drainage (L1, L2), stream water is a dilute calcium-sulfate-bicarbonate solution having a neutral $\mathrm{pH}$ and dissolved metal concentrations at or below the analytical detection limits. Between L2-and L3, the stream becomes acidic and there are substantial increases in dissolved aluminum, iron, and sulfate concentrations. The largest changes in solute concentrations occurred between LA and L5, just downstream from a large debris fan that covers much of the northwest side of Mount Moly (Yager et al., this volume). Between L2 and L7, manganese and zinc concentrations increased by about two orders of magnitude. By contrast, concentrations of most other trace metals remained relatively low, even in the lower reach of the tributary where $\mathrm{pH}$ values fell below 4.0.

Mass-loading profiles for the stream were calculated to help determine sources and sinks of dissolved metals along the stream reach (Kimball, 1997). Discharge and measured solute loads at each sampling point are plotted in Figure 2. Sites S11 and S10 are the major contributors of surface-water inflow along the reach (Fig. 2). These two source,s combined with a number of small springs, account-for -less than $20 \%$ of the measured flow at L7. This result indicates that ground-water discharge along the channel is the dominant source of flow to the stream. The loading profiles in Figure 2 show substantial increases in solute loadings along the reach, particularly between LA and L6. For example, along this $380-\mathrm{m}$ reach, sulfate loads increased by 4 times, aluminum by 40 times, iron by 180 times, and zinc by 20 times. Because the increase in discharge was only $20 \%$, the results suggest that ground-water discharge along LA-L6 must be rich in metals and sulfate. The average concentration of solutes in ground water can in fact be estimated based on the difference in loads between L4, L6, and S10 (Kimball, 1997). The calculation yields concentrations of 3,880 mg/L for sulfate, $315,000 \mu \mathrm{g} / \mathrm{L}$ for aluminum, $530,000 \mu \mathrm{g} / \mathrm{L}$ for iron, and $18,000 \mu \mathrm{g} / \mathrm{L}$ for zinc. These concentrations are 5 times higher than those measured in any of the sampled springs in the study area, suggesting that a different, perhaps deeper, source of ground water is contributing metals to the Red Tributary. Figure 2 also shows that iron behaves differently than the other constituents in the reach downstream from L6. This probably is due to precipitation of iron hydroxide minerals, as evidenced by the thick, reddish-orange ferricrete that coats the streambed below L5. Formation of iron hydroxides also is consistent with speciation calculations using PHREEQC (Parkhurst, 1995), which indicate that stream water in the lower reach was in equilibrium with ferrihydrite. Although loss of other constituents is not apparent from the loading profiles, hydroxysulfate minerals such as jarosite (K-Fe hydroxysulfate), schwertmannite (Fe hydroxysulfate), or jurbanite (Al hydroxysulfate) (Nordstrom and Alpers, 1999) also might be forming in the stream channel. Speciation calculations indicate that stream water was saturated with respect to jarosite and jurbanite at L5, L6, and L7. The streambed ferricrete has not yet been analyzed, although, schwertmannite and jarosite were identified in soil samples collected at the toe of the large debris fan upgradient of the LA-L6 stream reach (Yager et al., this volume).

$$
7-4
$$


Table 1 Water-quality data for streams and springs unaffected by mining in the Middle Fork Mineral Creek subbasin, 1995, 1997, and 1998

[Site locations shown in figure 1; Alt., dominant bedrock alteration type; QSP, quartz-sericite-pyrite; WS, weak sericitic; P, propylitic; Q, discharge; SC, specific conductance; DO, dissolved oxygen; Alk, alkalinity as $\mathrm{CaCO}_{3}$; <, less than; --, not measuredl

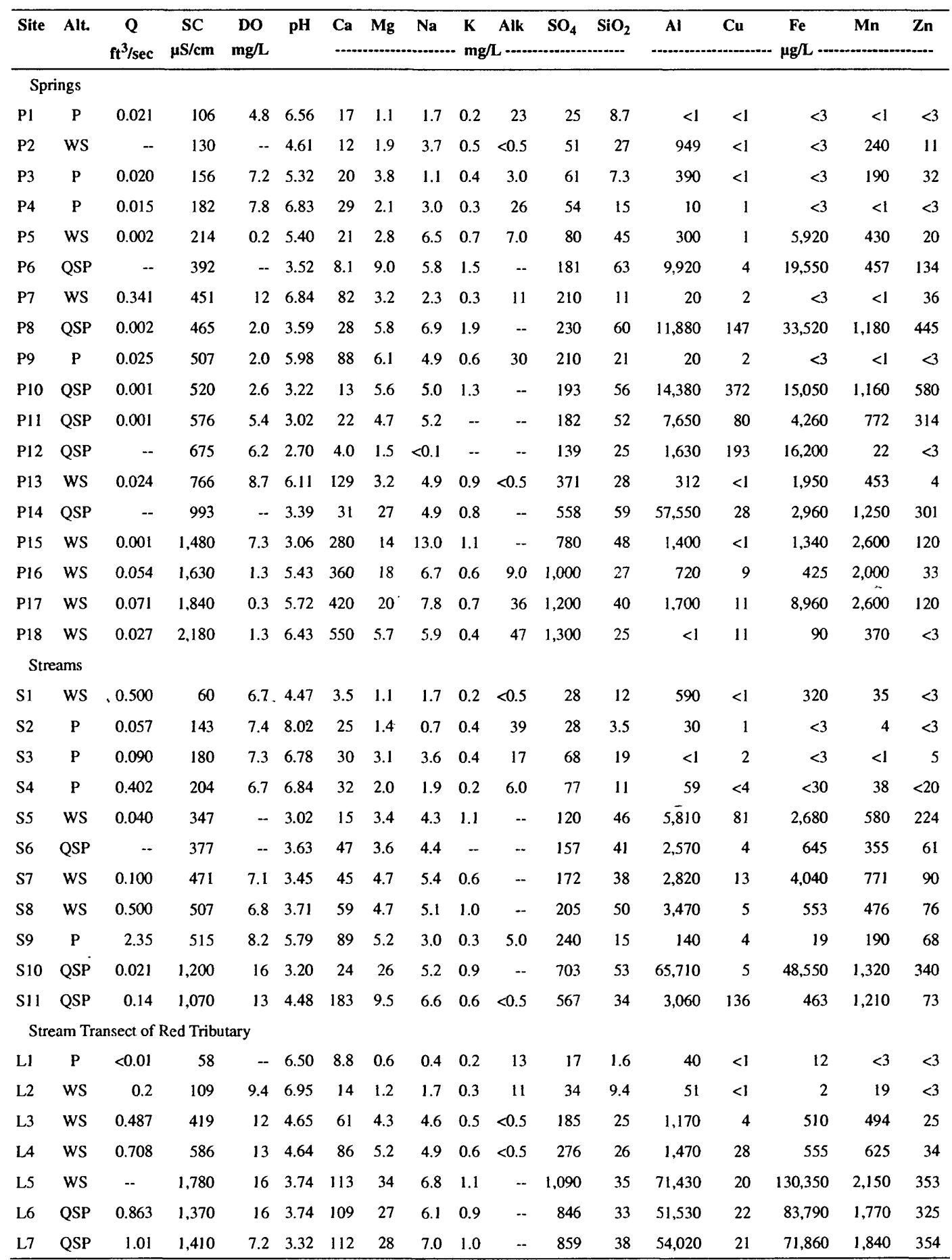




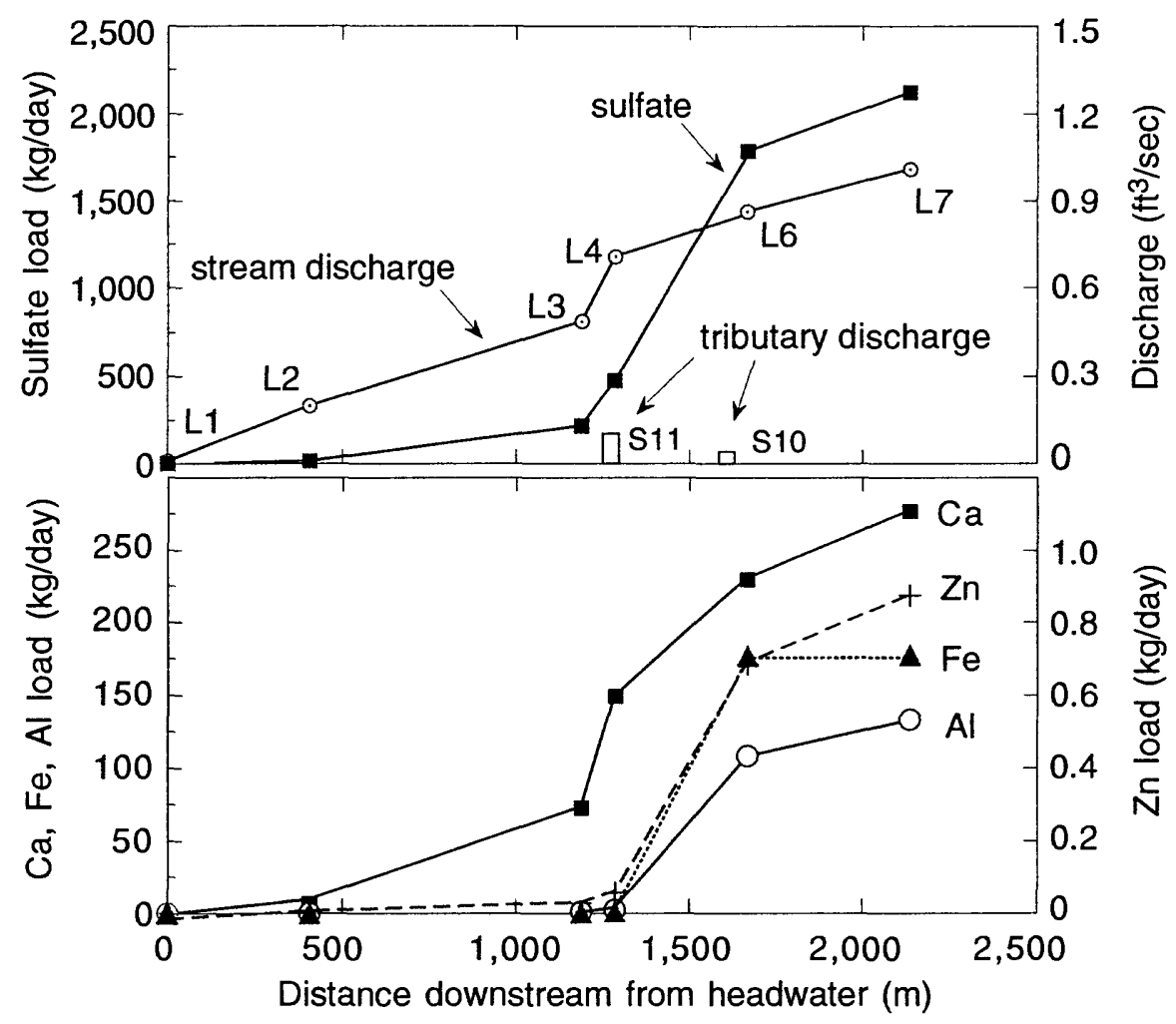

Figure 2 Discharge and mass loading profiles of dissolved sulfate, calcium, aluminum, iron, and zinc along the Red Tributary, October 2, 1998

\section{Relation Between Geology and Water Quality}

The chemistry of natural springs and streams in the study area showed a wide range of compositions that are spatially related to the degree of bedrock alteration (Table 1, Fig. 3). For example, streams and springs draining propylitically altered rocks had high $\mathrm{pH}$ values (5.3 to 8.0 ), measurable alkalinity ( 3 to $39 \mathrm{mg} / \mathrm{L}$ ), and low dissolved metal concentrations $(\mathrm{Zn}=<3$ to $68 \mu \mathrm{g} / \mathrm{L} ; \mathrm{Fe}=<3$ to $19 \mu \mathrm{g} / \mathrm{L} ; \mathrm{Al}=<1$ to $390 \mu \mathrm{g} / \mathrm{L}$ ). The propylitic rocks, which primarily underlie the northern and western part of the study area, contain up to several volume percent calcite, which dissolves to produce the neutral surface waters characteristic of this alteration type. Many of these springs and streams had sulfate concentrations as much as $240 \mathrm{mg} / \mathrm{L}$, indicating that disseminated pyrite in the propylitic rocks also is an important source of solutes, although there appears to be sufficient calcite to neutralize any acidity produced by the oxidizing pyrite. In contrast to the propylitic rocks, the QSP alteration zone is associated with acidic surface waters ( $\mathrm{pH} 2.70$ to 4.48 ) with concentrations of aluminum ranging from 1,630 to $65,710 \mu \mathrm{g} / \mathrm{L}$ and iron ranging from 463 to $83,790 \mu \mathrm{g} / \mathrm{L}$. These springs and streams primarily drain the flanks of Mount Moly and reflect an abundance of disseminated pyrite in the bedrock and a lack of buffering minerals such as calcite. Surface waters draining the WS zone generally were intermediate in composition between the QSP and propylitic waters, reflecting the transition between the two alteration zones. Many of the QSP- and WS-zone sites had high zinc and copper concentrations, which were derived from either base-metal veins localized along structures or from the disseminated pyrite (Ringrose, 1982; Bove et al., this volume). Sulfate concentrations were typically higher in the QSP and WS zones than in propylitic zone. Several springs, including $\mathrm{P} 7, \mathrm{P} 9, \mathrm{P} 16, \mathrm{P} 17$, and P18, had high sulfate concentrations as well as measurable alkalinity (Table 1). This pattern may be a result of the dissolution of some vein-filling gypsum or anhydrite (Wright and Nordstrom, 1999), which would produce calcium and sulfate without the associated acidity from pyrite oxidation.

$$
7-6
$$




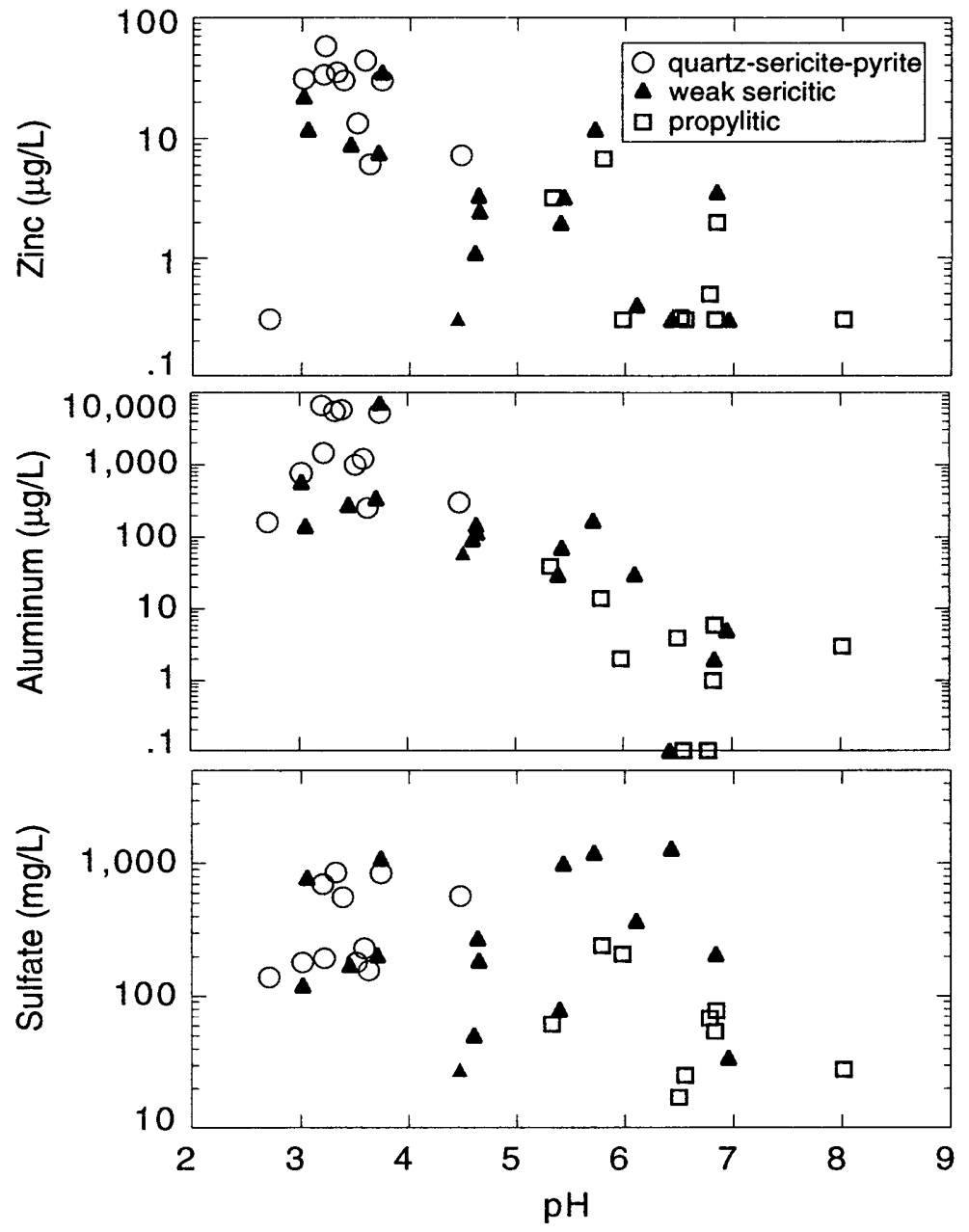

Figure 3 Zinc, aluminum, and sulfate concentrations in surface waters draining the three major aiteration zones as a function of $\mathbf{p H}$

To further constrain the possible weathering reactions controlling surface-water chemistry, simple massbalance models were constructed for waters draining the dominant bedrock alteration zones. More detailed information on the application of mass-balance models in mining envrionments can be found in Alpers and Nordstrom (1999). The mass-balance calculations were made using the computer code NETPATH (Plummer et al., 1994) and were used to predict the measured water chemistry by reacting meteoric water with the dominant minerals in the propylitic, weak sericitic (WS), and quartz-sericitc-pyrite (QSP) alteration zones. To avoid the additional complications of mixing and instream reactions, only spring-water samples were used in the modeling exercise. The chemistry of meteoric water was estimated from annual volume-weighted mean concentrations measured at a nearby precipitation-monitoring station located approximately $12 \mathrm{~km}$ south of the study area on Molas Pass. The modeling results for the three springs, P1, P5, and P14, were quite different, reflecting variations in the degree of bedrock alteration (Table 2). The chemistry of the propylitic-zone spring (P1) was controlled primarily by dissolution of calcite and a small amount of pyrite; this result is consistent with the presence of calcite and disseminated pyrite in the propylitized lavas (Ringrose, 1982). Small amounts of chlorite and albite were dissolved to account for other base cations. The major secondary phase is an ironhydroxide mineral such as ferrihydrite, which is required to remove the iron released by pyrite dissolution. The chemistry of the WS-zone spring (P5) also was controlled by calcite and pyrite dissolution; however, considerably more pyrite oxidation was needed at $\mathrm{P} 5$ to account for the lower $\mathrm{pH}$ and higher sulfate 
concentration at this site, as compared with Pl. Another notable difference between P1 and P5 is the increased importance of albite weathering in the WS zone, which is necessary to account for the higher sodium and silica concentrations. This difference may be the result of the acidity produced by additional pyrite oxidation, which might increase the dissolution rate of silicate minerals in the WS zone relative to the propylitic zone. Precipitation of iron hydroxide, kaolinite, and some aluminum hydroxide was necessary to remove iron, silica, and aluminum from solution. The model results for the QSP-zone spring (P14) show a predominance of pyrite weathering to account for the acidic iron-rich water at this site. Calcite dissolution is necessary to account for the calcium, which may come from pods of less altered rock within the QSP zone. Alternatively, calcium and some of the sulfate may be derived from vein-filling anhydrite that has been identified in drill cores from the center of the deposit (McCusker, 1982). The highly acidic waters in the QSP zone appear to promote the dissolution of an aluminosilicate mineral such as kaolinite, which is a common component of the QSP assemblage (Ringrose, 1982). Aside from iron hydroxide, silica was the only other secondary phase forming. Although the spring is close to saturation with respect to amorphous silica, this result may be an artifact of choosing kaolinite for the model rather than a more aluminum-rich phase such as andalusite or gibbsite. The results presented in Table 2 may not be the only reasonable models that account for the observed spring-water chemistry; however, they appear to be consistent with the mineralogy of the different alteration assemblages. Additional mineralogical data, particularly for soil minerals, would help to further constrain the weathering reactions.

Table 2 Results of mass-balance modeling of natural springs draining the dominant alteration assemblages in the study area. Positive values indicate mineral dissolution and negative values indicate mineral precipitation in units of millimoles of mineral per liter of water

\begin{tabular}{cccc}
\hline $\begin{array}{c}\text { Mineral Phases } \\
\text { (dissolved/precipitated) }\end{array}$ & $\begin{array}{c}\text { Spring P1 } \\
\text { (propylitic) }\end{array}$ & $\begin{array}{c}\text { Spring P5 } \\
\text { (weak sericitic) }\end{array}$ & $\begin{array}{c}\text { Spring P14 } \\
\text { (quartz-sericite-pyrite) }\end{array}$ \\
\hline Pyrite & 0.127 & 0.413 & 2.408 \\
Calcite & 0.417 & 0.517 & 0.767 \\
Chlorite & 0.009 & 0.022 & 0.222 \\
Sericite & 0.004 & 0.017 & 0.019 \\
Albite & 0.071 & 0.280 & 0.210 \\
$\mathrm{Kaolinite}$ & -0.051 & -0.105 & 0.710 \\
$\mathrm{Fe}(\mathrm{OH})_{3}$ & -0.127 & -0.307 & -2.850 \\
$\mathrm{Al}(\mathrm{OH})_{3}$ & -0.000 & -0.155 & 0.000 \\
$\mathrm{SiO}_{2}$ & -0.006 & -0.000 & -1.790 \\
\hline
\end{tabular}

Natural Contributions of Metals to the Middle Fork Mineral Creek

Natural contributions of metals from weathering were estimated using a mass-balance approach that consisted of calculating metal loadings from major mines in the study area and comparing the results to loads calculated at the mouth of the MFMC (Wright, 1997). All samples were collected in late September and thus represent an estimate of natural background only for base-flow conditions. The concentrations and loads of selected dissolved constituents and metals for six mines in the study area (M1-M6) and at the mouth of the MFMC (S12) are listed in Table 3, and site locations are shown in Figure 1. The total load from mining was calculated by multiplying the measured discharge at each mine site by the concentration and then summing the loads of all the mines. Assuming that the major mining-related sources are accounted for and that inputs of miningaffected ground water are minimal, the background contributions can be determined from the difference between the load of the MFMC and the total load from the mines. Because many metals such as iron and aluminum are not conservative in the stream channel (Kimball, 1997), these calculations should provide a minimum estimate of the natural metal contributions. Additionally, if some of the mine-adit discharge is fed by metal-rich springs that existed prior to mining (Nash, 1999), natural sources would be further underestimated by this technique. However, if the assumptions are not met, particularly concerning inputs of mining-affected ground water, natural contributions could be overestimated by this technique. Unfortunately, no information currently is available to evaluate the effect of mining on ground-water chemistry in the study area. 
The results of the calculations indicate that natural springs and streams accounted for about $80 \%$ of the discharge of the MFMC as well as a substantial fraction of the solute and metal loads in the study basin. For the major dissolved cations and sulfate, between $65 \%$ and $75 \%$ of the stream load was derived from natural sources. Natural contributions of dissolved metals varied over a slightly wider range from $56 \%$ for manganese to $90 \%$ for aluminum. The background contribution of zinc $(76 \%)$, which should be fairly conservative in the stream channel (Kimball, 1997), was similar to the contribution of sulfate (72\%), which also should be conservative. Wright and Nordstrom (1999) calculated a similar value for dissolved sulfate (71\%) in the MFMC by using an isotopic technique. Metal loads from the Red Tributary represented a significant contribution to the total dissolved metal load of the MFMC. Percentage contributions were similar to inputs from mining-related sources. For example, $20 \%$ of the zinc and $24 \%$ of the copper in the MFMC were derived from the Red Tributary compared to $24 \%$ of the zinc and $18 \%$ of the copper from mining-related sources. The high percentage of aluminum from natural sources was somewhat unexpected because aluminum from acidic mine waters is commonly removed by precipitation after discharging into the stream channel. The high natural contribution of aluminum in the study area is primarily due to discharge of acidic, aluminum-rich waters from the Red Tributary into the lower reach of the MFMC, which reduces the $\mathrm{pH}$ of the MFMC from 6.39 just upstream from the confluence with the Red Tributary to 4.75 at the confluence with Mineral Creek.

Table 3 Concentrations of dissolved constituents and metals in drainage from major mines in the study area and at the mouth of Middle Fork of Mineral Creek (MFMC). Total loadings from mines, MFMC, and Red Tributary, and calculated inputs from natural sources are listed on right side of table

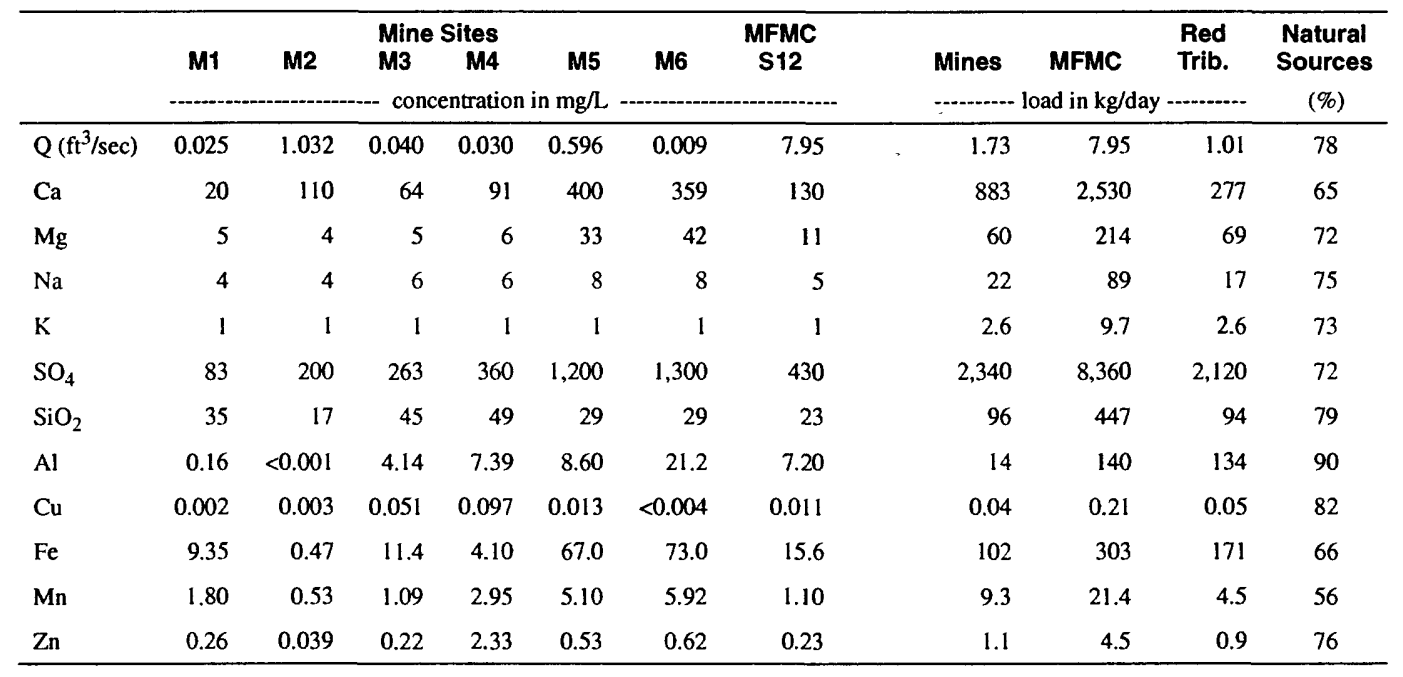

\section{SUMMARY AND CONCLUSIONS}

Surface-water chemistry in a minimally mined but mineralized subbasin of the UARW was studied to identify and quantify inputs of metals from natural weathering sources. The chemistry of natural streams and springs was variable with $\mathrm{pH}$ ranging from 2.70 to 8.02 and specific conductance ranging from 58 to $2,180 \mu \mathrm{S} / \mathrm{cm}$. Sites with neutral $\mathrm{pH}$ values were of the calcium-bicarbonate-sulfate water type, whereas low-pH waters were dominated by dissolved aluminum, iron, and sulfate. The chemistry of springs and streams unaffected by mining was found to be strongly controlled by the degree of bedrock alteration. Calcium-bicarbonate-sulfate waters were characteristic of propylitically altered rocks, whereas the QSP-altered rocks were characterized by acidic, metal-rich surface waters. The composition of most waters could be modeled by the weathering of variable amounts of pyrite, calcite, and aluminosilicate minerals, with pyrite and aluminosilicate dissolution becoming more important in the intensely altered zones. These results suggest that the chemistry of surface waters unaffected by mining in the UARW should be somewhat predictable if information is available on patterns of bedrock alteration and the associated mineral assemblages.

Synoptic samples were collected along the length of the Red Tributary to investigate downstream changes in stream chemistry in a naturally acidic stream. The largest change in stream-water concentrations occurred just downstream from a large debris fan that covers much of the northwest side of Mount Moly. Mass loading profiles for the stream indicated that the intensely altered bedrock of Mount Moly generates metal-rich ground 
water that was the dominant source of metals to the Red Tributary. Calculated ground-water concentratons were 5 times greater than those measured in any of the springs, indicating that different, perhaps deeper ground water is the dominant source of metals to the stream.

Natural contributions of metals in the study area were estimated using a mass-balance approach. This technique should provide a minimum estimate of metal inputs from natural sources. The results indicate that natural weathering of the altered bedrock accounted for $56 \%$ to $90 \%$ of the metal load at the mouth of MFMC during base-flow conditions. Much of this load was derived from a zone of intensely altered bedrock centered around Mount Moly. These results demonstrate that natural metal sources are significant and must be accounted for when establishing water-quality standards and remediation goals for the UARW.

\section{ACKNOWLEDGEMENTS}

This study was funded by the USGS Abandoned Mine Lands Initiative. Funding for P. Verplanck was provided by the National Research Council Postdoctoral Program. An earlier version of the manuscript was greatly improved by the comments of M. Kidd, T. Yager, J. Ball, H. Posey, and R. Schmiermund.

\section{REFERENCES}

Alpers, C.N. and D.K. Nordstrom. 1999. Geochemical modeling of water-rock interactions in mining environments. In The Environmental Geochemistry of Mineral Deposits. edited by G.S. Plumlee and M.J. Logsdon. Littleton, Colorado. Society of Ecomonic Geologists: 289-324.

Kimball, B. A. 1997. Use of tracer injections and synoptic sampling to measure metal loading from acid mine drainage. U.S. Geological Survey Fact Sheet 96-245.

McCusker, R.T. 1982. Mount Moly progress report, 1979-1980, Drill holes 1-6. Amax Exploration, Inc. unpublished report, $24 \mathrm{p}$.

Miller, W.R., J.B. McHugh, and A.L. Meier. 1995. Calculations of pre-mining geochemical baselines at three stream junctions in the vicinity of Summitville, Colo. U.S. Geological Survey Open-File Report 95-71.

Nash, J.T. 1999. Geochemical investigations and interim recommendations for priority abandoned mines sites on U.S.D.A. Forest Service Lands, Mineral Creek watershed, San Jan County, Colorado. U.S. Geological Survey Open-File Report 99-170.

Nimick, D.A. and P. von Guerard. 1998. Science for watershed decisions on abandoned mine lands: Review of preliminary results. U.S. Geological Survey Open-File Report 98-297.

Nordstrom, D.K. and C.N. Alpers. 1999. Geochemistry of acid mine waters. In The Environmental Geochemistry of Mineral Deposits. edited by G.S. Plumlee and M.J. Logsdon. Littleton, Colorado. Society of Ecomonic Geologists: 133-160.

Nordstrom, D.K., C.N Alpers, and W.G. Wright. 1996. Geochemical methods for estimating pre-mining and background water-quality conditions in mineralized areas. Geological Society of America, Abstracts with Programs, Annual Meeting, Denver, Colorado: A-465.

Parkhurst, D.L. 1995. User's guide to PHREEQC, a computer program for speciation, reaction-path, advective-transport, and inverse geochemical calculations. U.S. Geological Survey Water-Resources Investigations Report 95-4227.

Plummer, L.N., R.C. Prestemon, and D.L. Parkhurst. 1994. An interactive code (NETPATH) for modeling NET geochemical reactions along a flow PATH, version 2.0. U.S. Geological Survey Water-Resources Investigations Report 94-4169.

Ringrose, C.R. 1982. Geology, geochemistry and stable isotope studies of a porphyry-style hydrothermal system, West Silverton District, San Juan Mountains, Colorado. Ph.D. dissertation, University of Aberdeen, $257 \mathrm{p}$.

Runnells, D.D., D.P. Dupon, R.L. Jones, and D.J. Cline. 1998. Determination of natural background concentrations of dissolved components in water at mining, milling, and smelting sites. Mining Engineering 50(2): 65-71.

Runnells, D.D., T.A. Shephard, and E.E. Angino. 1992. Metals in water-Determining natural background concentrations in mineralized areas. Environmental Science and Technology 26: 2316-2323.

Wright, W.G. 1997. Natural and mining-related sources of dissolved minerals during low flow in the Upper Animas River Basin, Southwestern Colorado. U.S. Geological Survey Fact Sheet 148-97.

Wright, W.G., and D.K. Nordstrom. 1999. Oxygen isotopes of dissolved sulfate as a tool to distinguish natural and mining-related dissolved constituents. In Tailings and Mine Waste '99. Edited by L.L. Hinshaw. A.A. Balkema. Rotterdam, Netherlands: 671-678. 


\title{
The Role of Weathering in Trace Metal Redistributions in the Mayday Mine Dump near Silverton, Colorado
}

Mark R. Stanton ${ }^{l}$

\begin{abstract}
Geochemical and mineralogical analyses of 46 samples from six drill.cores in the Mayday mine pile near Silverton, Colorado, demonstrate wide variability in trace metal contents with spatial location. This variability results from the original geochemical composition of mined rocks, mixing of ore and nonore rocks during emplacement of the pile, and weathering since rocks were placed in the pile. Weathering reactions are controlled by factors such as pile thickness (depth), water availability, microbial activity, and mineral dissolution and formation kinetics. These factors result in variable redistributions of trace metals from primary (ore) to secondary (weathering products) minerals within each core.
\end{abstract}

\section{INTRODUCTION}

The ability of mine wastes to produce acidity and dissolved metals that may find their way into receiving waters is influenced by many factors. These include climate, host rock composition and mineralogy, material grain size and reactivity, thickness of the mine waste pile (depth to soil or bedrock), surface and ground water availability, microbial activity, and mineral dissolution and-formation kinetics.

Surface samples likely represent the most geochemically active component of mine wastes because they are exposed to the atmosphere and precipitation, and thus, weathering and mineral dissolution. Although deeply-drilled samples are more difficult to obtain, they provide opportunities to examine metal mobility and geochemistry at different depths in abandoned mine dumps. The distribution of metals and minerals in drill core samples from depths up to six meters ( $19 \mathrm{ft}$ ) in the Mayday mine dump near Silverton, Colorado, suggests that weathering processes similar to those at the surface also occur at depth and cause some trace metals to be mobile in the subsurface.

The spatial distribution of trace metals within primary (formed during ore emplacement) and secondary (formed by weathering) minerals at different locations in the Mayday mine dump indicates the metals owe their distribution to the following factors: 1) original geochemical composition of host (non-ore) and ore rocks, 2) initial placement of host and ore rocks onto the waste pile during mining, 3) oxidative weathering and differential solubilities of primary (ore) minerals, primarily sulfides, 4) formation of secondary minerals, primarily iron-sulfate salts, 5) microbial activity that affects the mobility of metals such as iron, and 6) aqueous (chemical) and hydrologic (physical) processes that affect downward and lateral movement of trace metals in the pile.

\section{SITE DESCRIPTION}

Surface rocks at the Mayday pile are variably stained by fine-grained, secondary (weathered) minerals, mainly red-to-orange iron oxides and yellow-to-gray jarosite type minerals (of the general formula $\left.\left[\mathrm{KFe}_{3}\left(\mathrm{SO}_{4}\right)_{2}(\mathrm{OH})_{6}\right]\right)$. Both iron-oxide and jarosite are inclusive terms used here to denote the fine-grained pile material that likely formed via oxidative decomposition of metal sulfide minerals, primarily pyrite $\left(\mathrm{FeS}_{2}\right)$, sphalerite $(\mathrm{ZnS})$, and galena $(\mathrm{PbS})$. Jarosite is used here to denote trace metal- (i.e., $\mathrm{Fe}, \mathrm{Pb}, \mathrm{Zn}$ ) and SO4- bearing phases. The compositions of the jarosite-type minerals in the pile vary widely (G.

${ }^{1}$ U.S. Geological Survey, Mail Stop 973, Denver Federal Center, Denver, CO 80225 
Desborough, USGS, written comm., 1999). Oxidative weathering of sulfide minerals can lead to release of metals, along with production of sulfate and acid.

The Mayday mine is $4 \mathrm{~km}(2.5 \mathrm{mi})$ north of the town of Silverton in San Juan County, Colorado (Figure 1). The pile is located $30 \mathrm{~m}$ west of Cement Creek at an elevation of $3035 \mathrm{~m} \mathrm{(9960} \mathrm{ft).} \mathrm{The}$ Mayday pile consists of two benches composed of mine dump material. The upper bench abuts the forested hillside to the west while the lower bench slopes down to meet the Cement Creek road to the east. The lower bench road (Figure 1) that divides the pile from north to south is generally devoid of mine waste material. The pile height from the Cement Creek road to the forested hillside is approximately 21 meters $(70 \mathrm{ft}$ ), and including both benches, approximately 80 meters $(250 \mathrm{ft}$ ) long by 50 meters ( $150 \mathrm{ft}$ ) wide, a surface area of approximately $4,000 \mathrm{~m}^{2}$. Only the upper bench and slope, and eastern slope of the lower bench, have significant amounts of mine waste. Of the six holes drilled, four are on the upper bench (1-4), one is on the lower bench near the foot of the upper bench slope (5), and one is at the foot of the lower bench next to the Cement Creek road (6). Drill hole 3 is in a scoured part of the upper bench and is approximately three $\mathrm{m}(10 \mathrm{ft})$ lower than holes 1,2 , and 4 .
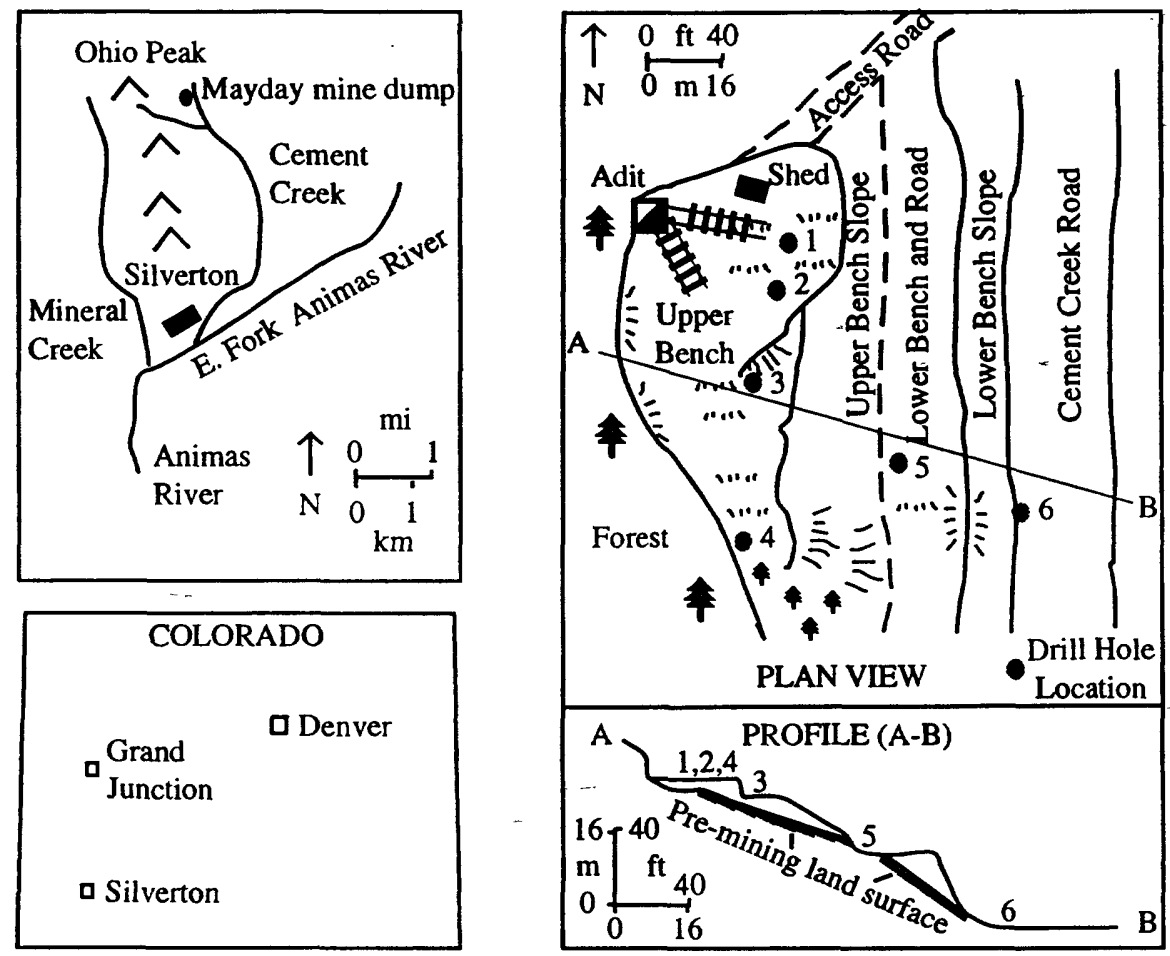

Figure 1 Location maps and plan and profile views of Mayday mine pile, showing approximate locations of the six drill holes, mine dump benches, and roads

The greatest thickness of the mine dump cored during the drilling operation was at drill hole 1 , which reached a soil horizon just below $6 \mathrm{~m}$ (19 ft). The dump is thinner towards the mountainside (west) and Cement Creek road (east). The shallowest hole drilled was hole 5, a depth of three $\mathrm{m}$ (10 ft).

The pile has no vegetation except for sparse cover over the upper bench and about a dozen small $(\leq 2$ $m$ tall) spruce trees at the edge of the pile near hole 4 . Vegetation on the adjacent mountainside consists of dense mixed pine, fir, and spruce forest with abundant plant cover on the ground surface. Extensive workings and relict ore-car rails and ties are on the surface of the upper bench and near the adit (Figure 1).

\section{Climate, Precipitation, and Drainage}

The site is within a montane biogeographic zone characterized by heavy snowfalls from about October to April that result in deep accumulations of snow. Snowpack depth prior to spring runoff often exceeds 
$6 \mathrm{~m}$ (19 ft). From about May to September, the area is subject to intermittent rain showers that vary in intensity from light to heavy, and in duration from a few seconds to several minutes or hours.

Although no major drainage traverses the mine pile, small rills, depressions, and erosional features on the benches and slopes indicate the Mayday pile receives intermittent runoff over the surface and along its edges. However, precipitation at the Mayday site is sporadic and the actual amount of runoff over the pile depends on seasonal and local weather conditions.

\section{Mining and Geology}

Production and mining records from the Mayday mine are generally lacking, but local records from other mines indicate the period of greatest activity was from approximately 1910 to 1950 (Bird, 1992). During mining, material was initially separated by placing non-ore (development and gangue) rocks at the outer (southern) edges of the mine dump while metal-rich ore rocks were delivered to haulage trucks in an area close to the mine workings. Old but still visible ore-car rails and ties show that ore was delivered to areas due east of the adit, while gangue and/or less-enriched ores were deposited south of the adit (see Figure 1).

The host rock for the Mayday mine is the Burns Formation, one of 3 major volcanic units in the San Juan Mountains (Lipman et al. 1973). The Burns Formation is composed primarily of light-to-dark gray silicic lava flows of thyolitic composition. Flows up to $250 \mathrm{~m}$ thick have been recognized in several. areas of the San Juan Mountains (Lipman et al. 1973). Fresh rock of the Burns Formation near the Mayday mine is brown-gray and generally free of iron-oxide coatings.

\section{DRILLING AND SAMPLING PROCEDURES}

Locations of the six drill cores from the Mayday pile are shown in Figure 1. From these six complete cores, 46 subsamples were obtained. The subsamples were selected in the field based on differences in lithology (sulfide-bearing vs unmineralized bedrock), grain size; alteration as indicated by iron oxide or jarosite (iron-sulfate) staining or rinds, the presence/absence of clays or clay-sized material, and organicmatter. Visible organic material consisted primarily of pieces of mine timbers strewn within the pile rocks, with minor contributions from rootlets and plant remains from the nearby forest. Few macroscopic differences were apparent in the samples with the exception of major iron-oxide (red) and jarosite (yellow) staining, or minor manganese-oxide (black) staining. Therefore, sample separation was based primarily on stain colors that suggested differences in alteration and weathering of the mine dump rocks.

Samples were described and separated into the 46 subsamples, then sealed in plastic bags for transport to the laboratory. Two additional subsamples ( $10 \mathrm{~g}$ each) were taken from each-core subsample on-site for microbial analysis to determine if iron- or sulfur-oxidizing microbes were present in the pile.

The midpoint depth of a sample interval defines sample locations. For example, sample H5-C2-M covers the interval from 2.4-2.8 $\mathrm{m}$ (5.0-6.0 ft); -its midpoint depth is thus $2.6 \mathrm{~m}(5.5 \mathrm{ft})$. These midpoint values are used to refer to samples in the data tables and to locate samples on downhole plots.

\section{ANALYTICAL METHODS}

Core samples were air-dried, split, powdered to $<230$ mesh (57 micron) using a shatterbox, then analyzed by inductively coupled plasma-atomic emission spectrometric analysis (ICP-AES) for 40 elements. Details of sample preparation and analytical techniques for this method can be found in Briggs (1990). Duplicate samples and quality assurance and quality control (QAVC) standards were included with each batch of samples analyzed. The powdered samples were also analyzed for total carbon $\left[\mathrm{C}_{(t o s)}\right]$ and total sulfur $\left[\mathrm{S}_{(\mathrm{bot})}\right]$ by $\mathrm{LECO}^{\circ}$ induction furnace methods (Curry, 1990a; 1990b).

For bulk X-ray diffraction work (XRD), a separate sieved aliquot of a $<230$ mesh composite sample was prepared as a packed powder mount and scanned with an $\mathrm{X}$-ray diffractometer using Ni-filtered $\mathrm{Cu} \mathrm{K}_{\alpha}$ radiation. The analytical parameters for all samples analyzed were as follows: generator settings of 40 $\mathrm{Kv}$ and $25 \mathrm{~mA}$, step size of 0.025 , and a one-second count time from $4^{\circ}-65^{\circ} 2 \theta$. The detection limit of a mineral phase with this method is $\geq 5$ volume percent.

Mineralogical results in composite samples are reported as major (concentrations of $>25 \%$ by volume), minor (concentrations of $\geq 5$ to $\leq 25 \%$ by volume), or trace (concentrations of $\leq 5 \%$ by volume). Major, minor, and trace designations are for qualitative purposes only and to convey relative abundances of crystalline phases detected in a sample. 
MINERALOGY OF ORE AND NON-ORE (HOST) ROCKS

Sulfides are the major ore minerals in the Silverton Mining District. Galena ( $\mathrm{PbS})$, sphalerite $(\mathrm{ZnS})$, pyrite $(\mathrm{FeS})_{2}$ ), and chalcopyrite $\left(\mathrm{CuFeS}_{2}\right)$ are found in many ore bodies (Lipman et al. 1973). Mineralogical and geochemical analyses for this report indicate "intact" (unweathered) ore minerals in the mine dump have retained their metal signatures. Gangue minerals in the ore rocks include quartz and feldspars.

Secondary minerals are those that formed at near-surface conditions via [acidic] weathering processes. These are primarily hydrous iron- and sulfate- bearing minerals such as jarosite-group $\left[\mathrm{KFe}_{3}\left(\mathrm{SO}_{4}\right)_{2}(\mathrm{OH})_{6}\right]$ and copiapite-group $\left[\mathrm{Fe}_{4}\left(\mathrm{SO}_{4}\right)_{6}(\mathrm{OH})_{2} \cdot 20 \mathrm{H}_{2} \mathrm{O}\right]$ minerals. These two groups comprise many minerals that vary in composition as a result of metal substitution. Qualitative XRD analyses of the $<230$ mesh fraction from Mayday subsurface samples show mixtures of varying proportions of ore sulfides and secondary phases.

\section{MICROBIAL ACTIVITY}

Iron- and sulfur-oxidizing bacteria of the genus Thiobacillus have been shown to be active geochemical agents in the oxidative weathering of sulfide minerals and production of acid drainage (Nordstrom and Southam, 1997). Greater numbers of two species, Thiobacillus ferrooxidans (iron-oxidizers) and Thiobacillus thiooxidans (sulfur-oxidizers), were present in ore samples compared to non-ore samples.

The field subsample was sieved to select grains smaller than $<63$ mesh $(0.23 \mathrm{~mm})$ for microbial isolations. Larger grains were not used because earlier work at a mine near Leadville, $\mathrm{CO}$ (Stanton et al. 1997), had shown thiobacilli were nearly always present in finer-grained (fine sand, silt, and clay) fractions.

Laboratory media selective for Thiobacillus ferrooxidans and Thiobacillus thiooxidans were prepared according to formulations by Atlas (1995) and Gerhardt et al. (1994), respectively. In addition to an initial low $\mathrm{pH}(\leq 4.0)$, the principal features of these media are the presence of a reduced iron source $\left(\mathrm{Fe}^{2+}\right)$ for Thiobacillus ferrooxidans or a reduced sulfur source (thiosulfate; $\mathrm{S}_{2} \mathrm{O}_{3}{ }^{2}$ ) for Thiobacillus thiooxidans. Solid $1.0 \mathrm{~g}$ samples were first placed into $9 \mathrm{~mL}$ of sterile $1 \% \mathrm{NaCl}$ for use as the primary inoculum. Using this $1-\mathrm{mL}$ saline suspension, culture tubes of the selective broth media were then serially-diluted (inoculated) from $10^{-1}$ to $10^{-3}$. The inverse of the highest dilution factor (D.F.) at which growth was observed was used as an estimate of the number of cells for that sample, for example, growth observed at the $10^{-3}$ D.F. $\approx 1,000$ cells $/ g$.

\section{AQUEOUS AND HYDROLOGIC MEASUREMENTS}

The drill holes were completed as piezometers to monitor changes in water levels and water chemistry in the mine dump. Measurement of water levels (W. Wright, USGS, written comm., 1999) show liquid water is available at most times of the year in the Mayday subsurface, but the amounts recovered from wells are small $(<100 \mathrm{~mL})$. Infiltration into the pile is limited and well levels reach their peak only during spring runoff, primarily via input from a small drainage west of the dump. Aqueous chemistry results indicate metal loads increase slightly during high flow periods (W. Wright, USGS, written comm., 1999). Flow paths in the pile are difficult to discem because of highly-variable "packing" of mine dump material and the wide variety of grain sizes that can impede or enhance subsurface water flow.

\section{RESULTS AND DISCUSSION}

\section{Trace and Major Element Distributions}

The downhole plots for the cores from holes 1, 2, and 3 in Figure 2 illustrate selected major and trace element abundances seen in most samples. Major elements are $\mathrm{Al}, \mathrm{Fe}, \mathrm{C}$, and $\mathrm{S}$; trace elements are $\mathrm{Pb}$, $\mathrm{Zn}, \mathrm{Cu}$, and $\mathrm{As}$. These eight elements have been identified as important constituents related to water quality issues in the region (Church et al. 1997). Table 1 shows the minimum and maximum values of these elements in all six drill cores.

\section{Mineral Dissolution and Precipitation}

Most sulfide minerals are formed at depth and under non-surface conditions (Sato, 1992). Sulfides are unstable in the surface environment and undergo oxidative weathering as a result of exposure to atmospheric oxygen, water, and microbial action. A common feature of non-ore volcanic clasts 
recovered at depth within the pile is the presence of iron-oxide rinds. Country rocks outside the pile (e.g., from drill core 4) and adjacent hillside rocks have no rinds, suggesting that mobile iron for rind formation comes from within the pile rather than from an outside source. A likely source for the iron in

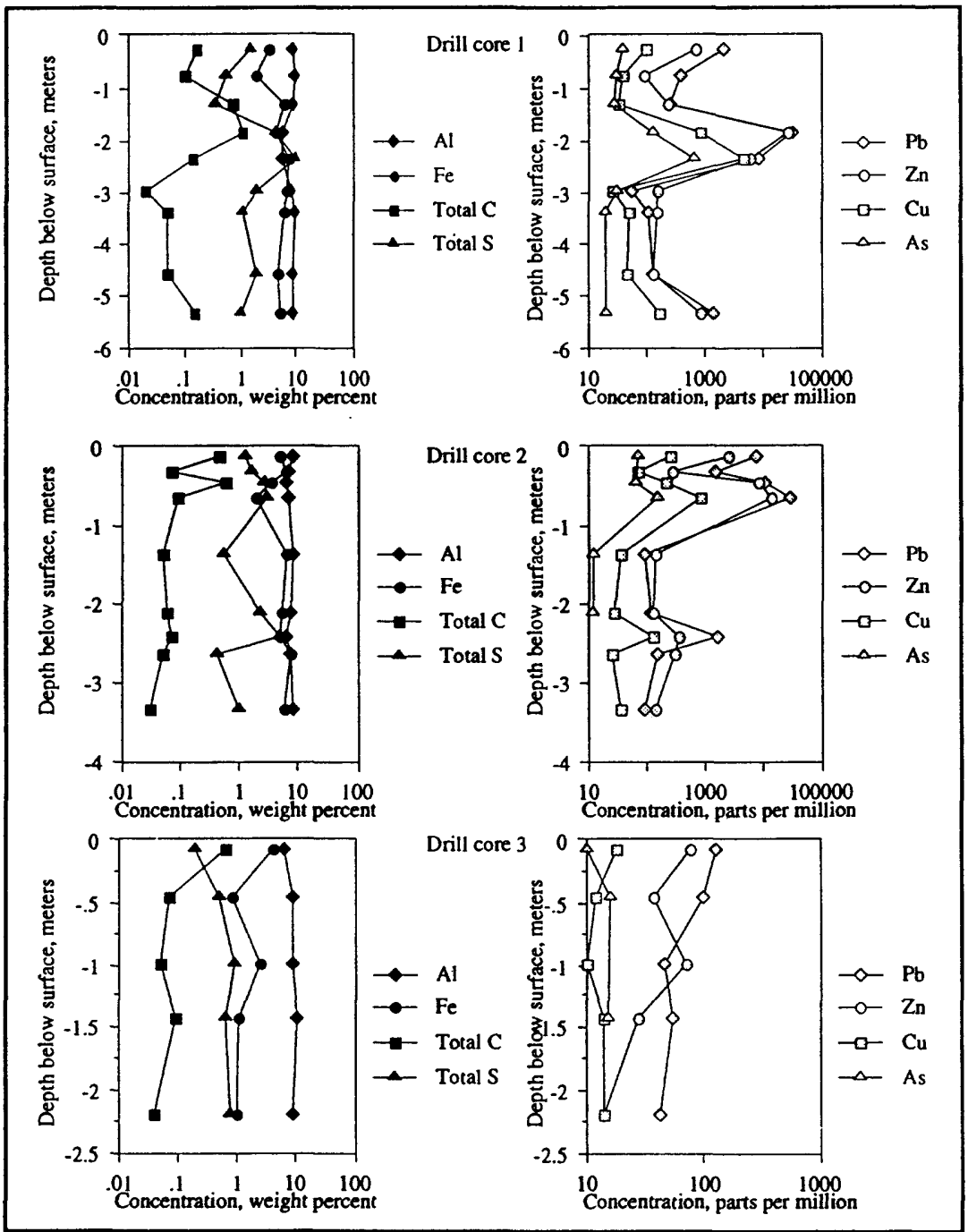

Figure 2 Downhole plots of major ( $\mathrm{Al}, \mathrm{Fe}, \mathrm{C}$, and $\mathrm{S}$ ) and trace ( $\mathrm{Pb}, \mathrm{Zn}, \mathrm{Cu}$, and $\mathrm{As}$ ) elements from drill cores 1 through 3 from the Mayday mine dump

the rinds is iron in sulfide minerals.

An example of the impact of weathering on the mine pile is demonstrated by samples from core 1 . Generally, only remnants of sulfides are seen in hand specimen and microscopic work in this core; the residual sulfides are found within a fine-grained matrix of yellow secondary minerals. The high concentrations of trace metals in the bulk material in the cores suggests that the drill holes penetrated an old zone of "ore" just beneath the pile surface.

Lead, $\mathrm{Zn}, \mathrm{Cu}$, and $\mathrm{As}$ reach their maximum abundances over approximately the $2-3 \mathrm{~m}(6-9 \mathrm{ft})$ depth interval in core 1 (samples H1-C2-M and H1-C2-B). Lead and zinc concentrations are 32,000 and 27,000 $\mathrm{ppm}$, respectively, in sample $\mathrm{H} 1-\mathrm{C} 2-\mathrm{M}$ which is centered at $1.8 \mathrm{~m}(6 \mathrm{ft})$. In fact, the lead and zinc abundances at this level in core 1 are the highest for both metals from all core samples. Lead and zinc exceed a few weight percent $(10,000 \mathrm{ppm}=1.0$ weight percent $)$ in just a few other samples in the Mayday mine dump; these high lead and zinc samples are from either core 1 or 2. 
Table 1 Minimum and maximum concentrations of select elements from Mayday drill core samples. Values are from composite samples. Units are weight percent for $\mathrm{AI}, \mathrm{Fe}$, total carbon $\left(\mathrm{C}_{(\mathrm{tot})}\right)$ and total sulfur $\left(S_{(10 t)}\right)$, and parts per million (ppm) for $\mathrm{Pb}, \mathrm{Zn}, \mathrm{Cu}$, and $\mathrm{As}$

Core 1

Core 2

Core 3

Core 4

Core $5 \quad$ Core 6

\begin{tabular}{l|ll|ll|ll|ll|ll|ll}
\hline & Min & Max & Min & Max & Min & Max & Min & Max & Min & Max & Min & Max \\
\hline Al & 5.4 & 9.1 & 6.5 & 8.7 & 6.7 & 11.0 & 1.8 & 7.6 & 7.1 & 8.4 & 7.2 & 8.6 \\
$\mathrm{Fe}$ & 1.9 & 7.4 & 2.0 & 8.0 & .82 & 4.2 & 2.5 & 4.7 & 3.6 & 6.3 & 4.3 & 6.3 \\
$\mathrm{C}($ tot) & .02 & 1.08 & .03 & .58 & .04 & .63 & .01 & .36 & .08 & .18 & .14 & .21 \\
$\mathrm{~S}(\mathrm{tot})$ & .36 & 9.14 & .43 & 5.21 & .20 & .89 & .39 & 5.05 & .26 & 1.04 & .23 & .62 \\
$\mathrm{~Pb}$ & 55 & 32000 & 88 & 30000 & 41 & 130 & 76 & 4700 & 59 & 550 & 140 & 340 \\
$\mathrm{Zn}$ & 92 & 27000 & 120 & 14000 & 14 & 79 & 21 & 5100 & 43 & 300 & 65 & 89 \\
$\mathrm{Cu}$ & 25 & 4600 & 26 & 820 & 10 & 18 & 20 & 140 & 9 & 33 & 14 & 34 \\
$\mathrm{As}$ & 19 & 680 & 12 & 160 & 10 & 16 & 11 & 120 & 19 & 58 & 11 & 61
\end{tabular}

Total sulfur (4.3 weight percent) and total carbon (1.0 weight percent) are also high where lead and zinc reach their maxima (Figure 2) in core 1. [Iron, however, is not especially high at 4.2 weight percent]. The association of high total sulfur $\left(S_{(00)}\right)$ with lead and zinc initially implies that a sulfidebearing zone of waste rock might be present at approximately 2 meters, and indeed, XRD analysis of this sample showed major $\mathrm{ZnS}$ ( $\geq 25$ volume percent) and minor ( $\geq 5$ to $\leq 25$ volume percent) $\mathrm{PbS}$. The yellow "jarosite" material imparted its color to the entire sample and coated both the mineral and organic detritus. Several weathered jarosite-type minerals (based on color differences) and several large (7-8 cm long $\times 1-2 \mathrm{~cm}$ diam) portions of old mine timbers were present in this sample.

Besides galena, other lead-bearing minerals identified by qualitative XRD include minor plumbojarosite $\left[\left(\mathrm{PbFe}_{6}\left(\mathrm{SO}_{4}\right)_{4}(\mathrm{OH})_{12}\right]\right.$ and trace $\left(\leq 5\right.$ volume percent) anglesite $\left(\mathrm{PbSO}_{4}\right)$ and cerrusite $\left(\mathrm{PbCO}_{3}\right)$. Another sulfate-bearing mineral, gypsum $\left(\mathrm{CaSO}_{4} \cdot 2 \mathrm{H}_{2} \mathrm{O}\right)$, was present in a trace amount. Quartz and muscovite were the only other minerals identified in samples $\mathrm{H} 1-\mathrm{C} 2-\mathrm{M}$ and $\mathrm{H} 1-\mathrm{C} 2-\mathrm{B}$. Thus, all but two minerals in these highly-weathered samples contain $\mathrm{Pb}, \mathrm{SO}_{4}$, or $\mathrm{Zn}$. Zinc is predominantly in the original ore sulfide sphalerite, while lead is distributed among four different minerals. Three of these minerals are secondary phases, indicating lead has been mobilized from the ore sulfide to the weathering products.

Microscopic examination of sample $\mathrm{H} 1-\mathrm{C} 2-\mathrm{M}$ (core $1 ; 1.8 \mathrm{~m}$ ) showed that the individual lead- and zinc- sulfide grains are small, less than $0.1 \mathrm{~mm}$ in diameter. The likely explanation for high lead (and to a lesser extent, zinc) in this oxidized (near-surface) zone is that these metals were originally (and are still) present in ore sulfides, then mobilized from sulfides but later reprecipitated within the secondary minerals, or perhaps adsorbed by the organic debris.

Aluminum shows only slight variation in core 2 and varies little in core 3 (Figure 2). But in core 1 , a decrease in aluminum concentration (from 8.2 to 5.4 weight perecent) at $1.8 \mathrm{~m}$ coincides with the large increases in lead and zinc. This suggets that either aluminum has been leached from core 1 samples or that the rocks originally emplaced were not silicates and therefore initially low in aluminum. Based on XRD identification of major sulfides (sphalerite), and a lack of Al-bearing primary or secondary phases in cores 1 and 2, aluminum was initially low in these samples and the material placed here was probably sulfide ore. In contrast, the increases in total sulfur and total iron in core 1 below $2 \mathrm{~m}$ (and below the lead and zinc maxima) indicate that iron and sulfur (as sulfate) have moved downward. Several Fe- and SO4bearing secondary phases were detected by XRD in these samples, and only minor sulfides $(\geq 5-\leq 25$ volume percent) were identified.

Arsenic and copper attain high concentrations at $2 \mathrm{~m}$ (130 and $870 \mathrm{ppm}$, respectively) but reach their maximum values in sample $\mathrm{H} 1-\mathrm{C} 2-\mathrm{B}$ (core $1 ; 2.3 \mathrm{~m}$ ), which is just below the lead and zinc maxima. At $2.3 \mathrm{~m}$, arsenic is nearly $700 \mathrm{ppm}$ and copper is $4600 \mathrm{ppm}$, while lead and zinc decrease by more than two-thirds to 8600 and $6000 \mathrm{ppm}$, respectively. Iron also is at its maximum abundance, 7.4 weight perecent, in this sample. There is much less total carbon ( 0.14 weight percent) but still high total sulfur (9.1 weight percent). There are no XRD detectable sulfides in sample H1-C2-B, only the secondary, finegrained, jarosite-type materials. The lack of ore sulfides but an abundance of secondary $\mathrm{Pb}-, \mathrm{Zn}-$, and $\mathrm{Fe}$ bearing phases suggests these metals have been mobilized and redeposited at a lower depth in the dump 
pile. The highest arsenic and copper values are also associated with the weathered iron-oxide/jarosite solids. Lead and zinc have decreased in abundance but are still high, indicating that their movement downward from the "ore" has been reduced at this point in the pile.

These results show that in addition to the original sulfide minerals located above sample H1-C2-B, $\mathrm{Pb}, \mathrm{Zn}, \mathrm{Cu}$, and $\mathrm{As}$ are now associated with the oxide-jarosite (and perhaps "organic") fractions. The presence of secondary (non-sulfide), metal- and sulfate-bearing minerals indicates weathering has played a strong role in the (downward) movement of major and trace elements in the dump pile. The actual transport mechanisms and routes of these elements from their source (sulfides) to current sink (oxidejarosite) are not known. Continuing work is aimed at understanding the mobility of the trace metals in the mine pile solids and waters.

A zone characterized by elevated lead and zinc concentrations is centered on core holes 1 and 2 at the two-meter depth. Lead and zinc values decrease laterally and downward from the top of the zone while the percentage of weathered minerals increases in those directions. In this zone, trace metals (especially lead) are now strongly-associated with weathered minerals as well as ore sulfides. The location and shape of this subsurface zone is in agreement with geophysical results (Instantaneous Potential [IP] method) from the Mayday pile (Campbell et al. 1999). While the original composition and metal abundances in this zone are not known, it is likely that the material was unweathered or only slightly weathered when first mined and placed in the pile. Thus, within less than 100 years, weathering of this "ore" material has been rapid.

\section{Microbial Activity}

Table 2 shows results of inoculations for Thiobacillus species for five samples from drill core 1 - these results are typical of most cores. Overall, the Thiobacillus thiooxidans medium showed a greater number of culture tubes positive for growth compared to Thiobacillus ferrooxidans. This result is not surprising because most iron is in $\mathrm{Fe}^{3+}$-oxide, so energy via $\mathrm{Fe}^{2+}$ oxidation is unavailable to Thiobacillus ferrooxidans. Pyrite abundance in this area of the pile is 1.0 weight percent or less (Campbell et al. 1999); the low but nonzero growth of Thiobacillus ferrooxidans may be explained by the presence of small amounts of pyrite. In other cores, most tubes positive for Thiobacillus ferrooxidans were obtained from samples that contained XRD-detectable ( $\geq 5$ volume percent) pyrite.

Table 2 Results for growth of thiobacilli from samples in drill core 1. Each symbol (+; growth) or (-; no growth) represents one tube at the dilution factor shown. Midpoint depth (m) for the sample interval is shown in parentheses

\begin{tabular}{|c|c|c|c|}
\hline $\begin{array}{l}\text { Core } \\
\text { Sample }\end{array}$ & $\begin{array}{l}\text { Dilution } \\
\text { Factor }\end{array}$ & $\begin{array}{l}\text { Thiobacillus } \\
\text { thiooxidans }\end{array}$ & $\begin{array}{l}\text { Thiobacillus } \\
\text { ferrooxidans }\end{array}$ \\
\hline $\mathrm{H} 1-\mathrm{Cl}-\mathrm{T}$ & $10^{-1}$ & -++ & $\ldots$ \\
\hline \multirow[t]{2}{*}{$(0.2 \mathrm{~m})$} & $10^{-2}$ & -++ & $\ldots$ \\
\hline & $10^{-3}$ & +++ & $\ldots$ \\
\hline $\mathrm{H} 1-\mathrm{Cl}-\mathrm{B}$ & $10^{-1}$ & -++ & $\ldots$ \\
\hline \multirow[t]{2}{*}{$(0.7 \mathrm{~m})$} & $10^{-2}$ & -++ & $\ldots$ \\
\hline & $10^{-3}$ & +++ & $\ldots$ \\
\hline $\mathrm{H} 1-\mathrm{C} 2-\mathrm{T}$ & $10^{-1}$ & -++ & +++ \\
\hline \multirow[t]{2}{*}{$(1.3 \mathrm{~m})$} & $10^{-2}$ & $\ldots$ & +++ \\
\hline & $10^{-3}$ & $\ldots$ & $+\cdots$ \\
\hline $\mathrm{H} 1-\mathrm{C} 2-\mathrm{M}$ & $10^{-1}$ & +++ & $+\cdots$ \\
\hline \multirow{2}{*}{$(1.8 \mathrm{~m})$} & $10^{-2}$ & ++- & $\ldots$ \\
\hline & $10^{-3}$ & +++ & $\ldots$ \\
\hline $\mathrm{H} 1-\mathrm{C} 2-\mathrm{B}$ & $10^{-1}$ & +++ & +++ \\
\hline \multirow[t]{2}{*}{$(2.3 \mathrm{~m})$} & $10^{-2}$ & ++- & +-+ \\
\hline & $10^{-3}$ & ++- & $+\cdots$ \\
\hline H1-C3-B & $10^{-1}$ & ++- & +++ \\
\hline \multirow[t]{2}{*}{$(3.4 \mathrm{~m})$} & $10^{-2}$ & +++ & +++ \\
\hline & $10^{-3}$ & $++t$ & -++ \\
\hline
\end{tabular}


An interesting result is the lack of iron-oxidizing thiobacilli from sample $\mathrm{Hl}-\mathrm{C} 2-\mathrm{M}$ (core $1 ; 1.8 \mathrm{~m}$ ), which is characterized by high lead $(32,000 \mathrm{ppm})$ and zinc $(27,000 \mathrm{ppm})$; other trace metals (Ag, As, Cd) are also high. Despite these high metals, sulfur-oxidizing thiobacilli are plentiful. It appears that high metal concentrations may be retarding growth of iron-oxidizers but not sulfur-oxidizers. This may be a result of the fact that the sample mineralogy is dominated by [fine-grained] lead and zinc sulfides, rather than pyrite. Recent work by Schippers and Sand (1999) has shown that mineralogy will affect the type of sulfide mineral degradation pathway employed by thiobacilli. For example, when $\mathrm{Fe}^{3+}$ is absent, Thiobacillus ferrooxidans can solubilize iron-free sulfides (e.g., CuS) but not $\mathrm{FeS}_{2}$, and thus behaves more like Thiobacillus thiooxidans. There are other possible reasons for the lack of growth of ironoxidizers. For example, trace metal concentrations other than lead or zinc, such as copper or silver, may be high enough to inhibit growth of thiobacilli. And as noted above, because all iron is already in the $\mathrm{Fe}^{3+}$ state, no energy is available to iron-oxidizing microbes. Regardless of the cause, the results suggest that mineralogy and trace metal abundances affect the numbers of iron- and sulfur- oxidizing bacteria that are found in mine dump samples.

Aqueous and Hydrologic Processes

Abundances of secondary (weathered) minerals in drill core samples indicate that trace metal movement away from ores occurs via dissolution and formation of the secondary phases. In turn, this dissolutionformation mechanism suggests metals are moving in response to aqueous processes that are influenced by mine pile hydrology (porosity, permeability, infiltration of surface water). Although the hydrologic properties of the mine pile are beyond the scope of this paper, observations show that the Mayday pile is subject to intermittent (and perhaps infrequent) water infiltration that permits aqueous geochemical reactions to occur in the subsurface. For example, iron-oxide rinds were found only on subsurface rocks. Increases in metals loads with high flow periods also indicate mineral solubilization and metal mobilization is occurring in subsurface materials (W. Wright, USGS, written comm., 1999).

\section{SUMMARY}

Weathering of primary ore minerals has resulted in a zone of high-trace-metal containing secondary minerals located near old ore mineral accumulations in the Mayday mine dump centered around drill holes I and 2. These mineral accumulations coincide with historical and visual observations of ore placement during mining. Because the original emplacement of ore minerals cannot be precisely determined, the results of this investigation define only the limits to the potential movement of trace metals from primary to secondary mineral phases. Microbial activity, or a lack thereof, may be a key control on the dissolution of sulfides and immobility of iron as evidenced by the lack of iron-oxidizing microbes but an abundance of sulfur-oxidizing bacteria in a lead/zinc ore that contained minor pyrite. Water availability is highly variable at the Mayday pile, suggesting that infiltration and aqueous weathering reactions happen only on a sporadic basis rather than at all times of the year. Thus, the rates of mineral dissolution will also vary.

\section{CONCLUSIONS}

Examination of drill core samples suggests that surface weathering processes also operate at depth in the Mayday mine dump. The high concentration of lead associated with weathered mineral phases, large numbers of iron- and sulfur- oxidizing microbes (compared to non-ore samples), and abundant secondary minerals and iron-oxide rinds on clasts indicate several metals are mobile in the subsurface in the Mayday mine dump.

\section{REFERENCES CITED}

Atlas, R.M., 1995. Handbook of Media for Environmental Microbiology. CRC Press, Boca Raton, FL.

Briggs, P. H., 1990, Elemental analysis of geologic materials by inductively coupled plasma-atomic emission spectrometry, In Quality assurance manual for the Branch of Geochemistry, U.S. Geological Survey, ed. B.F. Arbogast, 83-91. U.S. Geological Survey Open-File Report 90-668.

Bird, A.G., 1999. Silverton Gold: The Story of Colorado's Largest Gold Mine.

Campbell, D.L, R.J. Horton, R.J. Bisdorf, D.L. Fey, M.H. Powers, and D.V. Fitterman, 1999. Some geophysical methods for tailings/mine waste work. Proceedings of Sixth International Conference on Tailings and Mine Waste, 35-43. Balkema Publishers, Rottterdam, Netherlands. 
Church, S.E., B.A. Kimball, D.L. Fey, D.A. Ferderer, T.J. Yager, and R.B. Vaughn, 1997. Source, transport, and partitioning of metals between water, colloids, and bed sediments of the Animas River, Colorado. U.S. Geological Survey Open-File Report 97-151.

Curry, K.J., 1990a. Determination of total carbon in geologic materials by combustion, In Quality . assurance manual for the Branch of Geochemistry, U.S. Geological Survey, ed. B. F. Arbogast, 11418. U.S. Geological Survey Open-File Report 90-668.

Curry, K.J., 1990b. Determination of total sulfur in geologic materials by combustion, In Quality assurance manual for the Branch of Geochemistry, U.S. Geological Survey, ed. B. F. Arbogast, 13135. U.S. Geological Survey Open-File Report 90-668.

Gerhardt, P., R.G.E. Murray, W.A. Wood, and N. R, Krieg, eds., 1994. Methods for General and Molecular Bacteriology. Am. Soc. Micro., Washington, D.C.

Lipman, P.W., T.A. Steven, R.G. Luedke, and W.S. Burbank, 1973. Revised volcanic history of the San Juan, Uncompahgre, Silverton, and Lake City calderas in the western San Juan Mountains, Colorado. U.S. Geological Survey Jour. Research, v. 1, 627-42.

Nordstrom, D.K., and G. Southam, 1997. Geomicrobiology of Sulfide Oxidation, In Geomicrobiology: Interactions between Microbes and Minerals, J.F. Banfield and K.H. Nealson, eds., 361-90. Reviews in Mineralogy, v. 345.

Sato, M., 1992. Persistency-field Eh-pH diagrams for sulfides and their application to supergene oxidation and enrichment of sulfide ore bodies. Geochim. Cosmochim. Acta, v. 56, 3133-56.

Schippers, A., and W. Sand, 1999. Bacterial leaching of metal sulfides proceeds by two indirect mechanisms via thiosulfate or via polysulfides and sulfur. Appl. Env. Micro., v. 65, 2319-21.

Stanton, M.R., R.B. Vaughn, G.A. Swayze, and E.I. Robbins, 1997. Mineral crusts or microbial mats?: alteration of surficial mine tailings, Leadville District, CO. Abstract, Fourth International Symposium on Environmental Geochemistry. 


\title{
Utilization of Airborne Magnetic, Electromagnetic, and Radiometric Data in Abandoned Mine Land Investigations
}

\author{
Bruce D. Smith', Anne E. McCafferty', and Robert R. McDougal ${ }^{l}$
}

\begin{abstract}
Magnetic, electromagnetic, and radiometric airborne survey data have been used in regional and local (drainage basin) scales. In a regional geoenvironmental assessment of the state of Montana, magnetic and radiometric data compiled from airborne surveys were used along with other digital geologic and geochemical data to prioritize mining districts for potential acid water generation. Probability ratio mapping was done in order to integrate the interpretation of many different digital data sets. On a more local scale, the Animas (CO) and Boulder Basin (MT) watersheds have been studied using helicopter geophysical surveys. The airborne geophysical surveys show many more structural features than the geologic maps. Combined interpretation of the geophysical data sets using the probability ratio method has resulted in identification of areas of alteration. Airborne radiometric data in the Boulder Basin area suggests that rocks with high potassium and thorium also have a high acid water .buffering capacity.
\end{abstract}

\section{INTRODUCTION}

The U.S. Geological Survey, Mineral Resources Program, has been conducting integrated geological, geochemical, and geophysical investigations of abandoned mine lands (AML) in Colorado and Montana watersheds. The overall objective of the AML project is to characterize the watersheds and to prioritize sites within the drainage basins for remediation. One significant task in the remediation process is the siting of possible repositories for mine tailings so as to avoid adversely affecting drainages within the study area.

The Animas (Colorado) and Boulder Basin(Montana) watersheds (Figure 1) are the sites of historical mining for volcanogenic precious metals deposits. The Animas deposits are related to a Tertiary caldera complex located in an area characterized by some of the most rugged terrain in North America, with elevations of some peaks exceeding $4.5 \mathrm{~km}$ (14000 $\mathrm{ft}$ ). There are rock exposures over about $60 \%$ of the study area. Ore deposits of the Boulder Basin are precious metal veins situated in the upper part of the Cretaceous Boulder Batholith. This study area, located along the continental divide, has rolling topography with hills up to $2 \mathrm{~km}(7000 \mathrm{ft})$. Rock exposures are present, but colluvial and glacial cover obscures rock exposures over about $80 \%$ of the study area.

\footnotetext{
${ }^{I}$ U.S. Geological Survey, Denver Federal Center, PO Box 25046, MS973, Denver, CO, 80225
} 


\section{AIRBORNE GEOPHYSICAL METHODS}

Mineral exploration and, more recently, ground water investigations have used a wide variety of airborne geophysical methods to map near surface and subsurface physical property variations of large tracts of land. In this study airborne surveys were used in the two watersheds to characterize physical properties which are important in AML investigations. Campbell and Fitterman (2000) discuss many of the geoelectrical properties significant in the study of mine dumps.

Airborne techniques can be applied at both a regional scale (for example the scale of a state) and local scale (watershed or smaller). In general helicopter surveys are carried out in mountainous terrains where detailed subsurface or near surface mapping is needed on a local scale. Surveys requiring less detail on a regional scale or in relatively flat terrain use fixed wing aircraft. Table 1 summarizes the airborne geophysical methods used in the studies discussed here.

Table 1 Summary of Airborne Geophysical Methods

\begin{tabular}{lll}
\hline Method & Physical Property & General Depth of Investigation \\
\hline $\begin{array}{l}\text { Magnetic (either helicopter or } \\
\text { fixed wing) }\end{array}$ & $\begin{array}{l}\text { magnetic susceptibility (rock } \\
\text { magnetization) }\end{array}$ & $\begin{array}{l}\text { few meters to hundreds of } \\
\text { meters (depends on wavelength } \\
\text { of anomaly) }\end{array}$ \\
$\begin{array}{l}\text { Radiometrics (either helicopter } \\
\text { or fixed wing) }\end{array}$ & $\begin{array}{l}\text { gamma radiation from uranium, } \\
\text { thorium, and potassium }\end{array}$ & near surface (screened by water) \\
$\begin{array}{ll}\text { Electromagnetics (Helicopter) } \\
\text { conductivity (or reciprocal } \\
\text { resistivity) }\end{array}$ & $\begin{array}{l}\text { few meters to about 60 meters } \\
\text { conductivity (or reciprocal } \\
\text { resistivity) }\end{array}$ & few meters to 100 meters \\
\hline
\end{tabular}

\section{Regional Application of Airborne Geophysical Methods}

Lee et. al. (1999) utilized a wide variety of geologic, geochemical, and geophysical data sets in a geoenvironmental assessment of mining districts within the state of Montana. Airborne geophysical data used in this study consisted of aeromagnetics (McCafferty, et al., 1998) and radiometrics. Derivative products from the aeromagnetics used in the interpretation include:
a) reduction to the pole,
b) gradient enhancement, and
c) terrace mapping (Cordell and McCafferty, 1989).

A critical aspect of this regional study is the "probability ratio mapping" method, which was also used by McCafferty et. al. (1999) in modeling of airborne geophysical data to map different lithologic terrains in a local study of Southeastern Alaska. In the Montana geoenvironmental study, individual digital data sets were scale transformed or divided into classes. Correlations between classes of geochemical, geologic, and geophysical data were tested to determine whether a spatial association exists with known metal mining districts. The mine districts act as prototype areas and share the distinction of having a high potential to generate acidic metal-rich drainage. One of the resulting areas of high potential to generate acid drainage, the Boulder Basin, was selected by federal land use managers for further detailed studies.

\section{Local Scale Applications of Airborne Geophysical Methods}

During December of 1996 and 1997 helicopter magnetic and electromagnetic (EM) surveys were flown under contract by the USGS Mineral Resources Program, Abandoned Mine Lands Project, over the Boulder Basin watershed. The surveys were made along flight lines spaced $220 \mathrm{~m}(1 / 8 \mathrm{mile})$ apart with measurements about 
every 3 meters along the flight path. Flight lines were flown in a NW-SE direction. The nominal altitude of the helicopter was $60 \mathrm{~m}$ above terrain except over populated areas, or at an altitude appropriate for safe flying (for example over a steep narrow canyon).

The electromagnetic field was measured at 3 frequencies $(900,7200$, and $52000 \mathrm{~Hz})$ using horizontal coplanar transmitting and receiving coils towed in a "bird" (a $10 \mathrm{~m}$ tube) $30 \mathrm{~m}$ below the aircraft (see Figure 2). The depth of investigation for the EM measurements varies as a function of frequency with the highest frequency having a depth of investigation of a few to 10 meters. The lowest frequency can explore as deep as 60 meters. The exact exploration depths depend on the subsurface earth conductivities. In conductive areas, the depth of exploration decreases and in resistive areas it increases. Use of multiple frequencies with different exploration depths allows qualitative and quantitative interpretations to be made for different depth intervals.

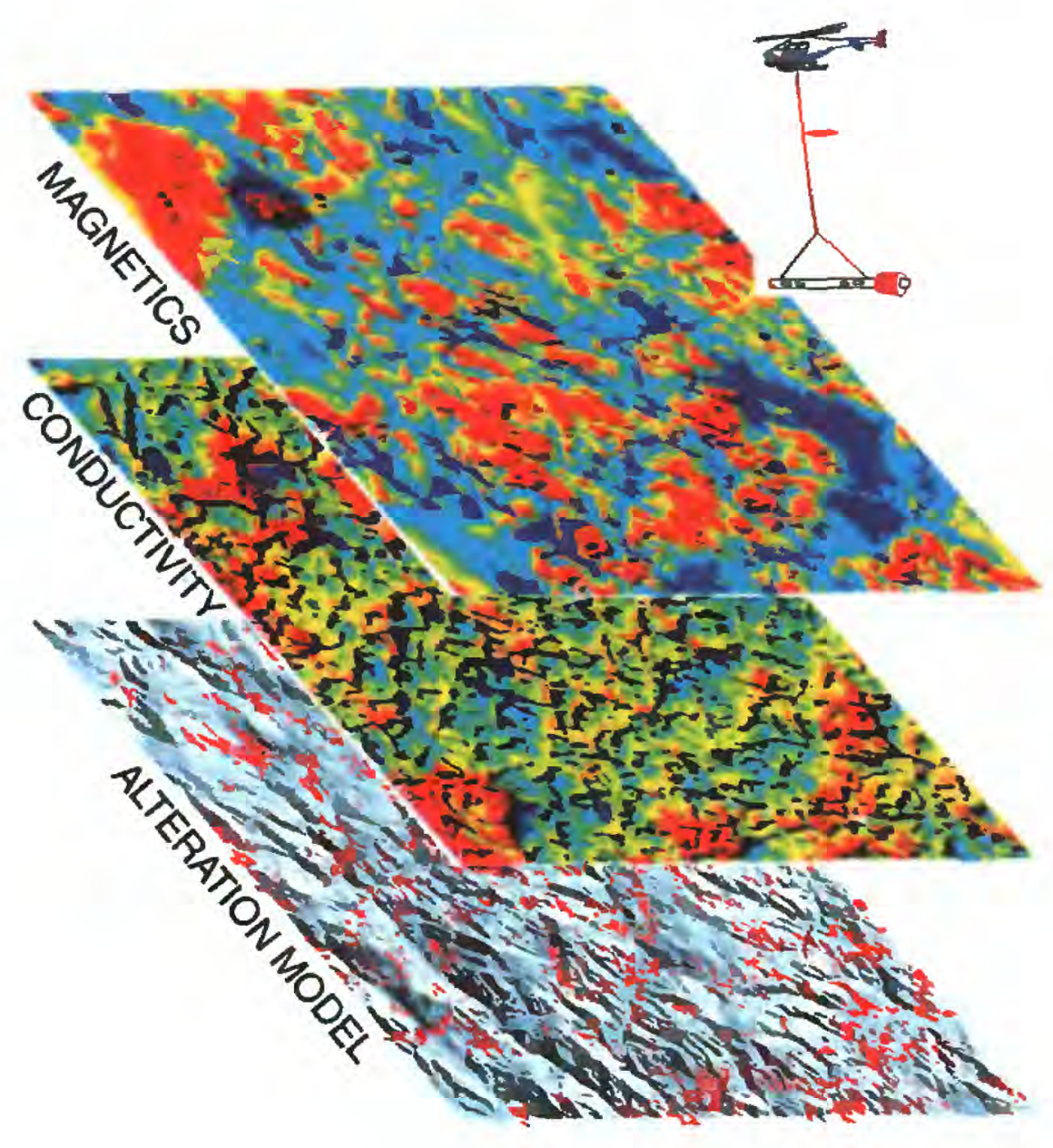

Figure 2 Schematic illustration of geophysical layers (magnetic and $7200 \mathrm{~Hz}$ conductivity) used to produce an interpretive alteration map (see color figure in addendum this volumn). 
Several different digital data sets form the basis for an integrated interpretation of near surface and subsurface features relating to the assessment of acid mine drainage and remediation efforts. Figure 2 illustrates a schematic relationship between airborne magnetic and electromagnetic data and a geologic model. The correlation between different layers can be carried out by classical geographic information systems (GIS) methods. Another method, briefly described above, is the probability ratio mapping method that quantitatively relates characteristics of each layer to formulate a geologic interpretation.

\section{Magnetic and Electromagnetic Interpretation Examples}

Processing of airborne geophysical data for many applications consists of producing maps emphasizing anomalous areas, trends, and/or level changes (Van Blaricom, 1992). This type of analysis has been done for the local airborne data sets in this study. In the Boulder area, one obvious conclusion from comparison of the mapped geology (Becraft et al., 1963; Ruppel 1963) and geophysical trends is that there is much greater spatial variation in the geophysical data than in the geological map. This is in part due to the fact that much of the geology is covered in the Boulder Basin area. Many of the geophysical trends may be associated with lithologies which readily erode and are not exposed for surface geological mapping.

Figure 3 shows a gradient trend analysis of total field magnetic data and $7200 \mathrm{~Hz}$ apparent conductivity data. The strong WNW trend in both data sets correlates with the trend of the mapped mineralized vein system. Generally the vein systems are correlated with lineaments consisting of magnetic lows and conductivity highs. We note that the $7200 \mathrm{~Hz}$ conductivity data (Figure 3 ) shows a small NNE ( N1 $\left.5^{\circ} \mathrm{E}\right)$ trend in addition to the general WNW trend. Inspection of color shaded relief maps of the conductivity shows that where these northerly trending lineaments intersect the westerly trending lineaments, there has been significant development of mineral deposits. The northerly oriented lineaments also occur in places along drainages which have been significantly impacted by acid mine waters. Further investigations are needed in these areas to evaluate possible subsurface contaminant pathways and natural (pre-mining) contributions to high metal contents along these drainages.

Geologic investigations along some of the NS geophysical lineaments indicate that these features are associated with late stage magmatic leucogranitic phases of the Boulder Batholith. These nonmafic rocks have been highly altered and tend to be associated with topographic lows and stream drainages along which there are few exposures. Such late stage magmatic rocks are difficult to map in the field, and may explain why the geophysical maps are more complex than the geologic map.

The good results of the airborne geophysical survey in the Boulder Basin prompted us to fly a similar survey in the Animas AML study area. Preliminary examination of these data indicate that they will be valuable for subsurface lithology, structure, and ground water mapping. In the Animas area, issues involving pre-mining ground water contamination are much more prominent than for the Boulder Basin study.

\section{Radiometric Data}

Spectral radiometric data collected in a separate airborne survey covering the SE corner of the Boulder Basin study area consists of total count, potassium, uranium, and thorium channels which have been corrected by the contractor. Traditional use of radiometrics for geologic mapping includes recognition of potassium alteration patterns associated with mineralization processes (Shives et al., 1997). Such alteration patterns can be useful in mapping the "plumbing system" of mineralization processes.

In addition to this application, we suggest that radiometrics can be used as a rough guide to the buffering capacity of near surface rocks. Desborough et al., (1998) demonstrate the following buffering characteristics of the rocks in the study area:

1) volcanic rocks (both Cretaceous Elkhorn Mountain and the Tertiary Low Land Creek) have low buffering capacity, and

2) the more mafic magmatic rocks of the Boulder Batholith have a higher buffering capacity.

In the airborne radiometric survey the exposed volcanic rocks are generally correlated with lows in potassium and thorium. The younger Low Land Creek volcanics tend to have a lower thorium signature than the older volcanics. In contrast the magmatic rocks of the Boulder Batholith in this area have higher airborne potassium and thorium signatures. We conclude that in this geologic environment, lithologies correlated with low potassium and thorium will have low buffering capacity and those correlated with potassium-thorium highs will have high 
buffering capacity.

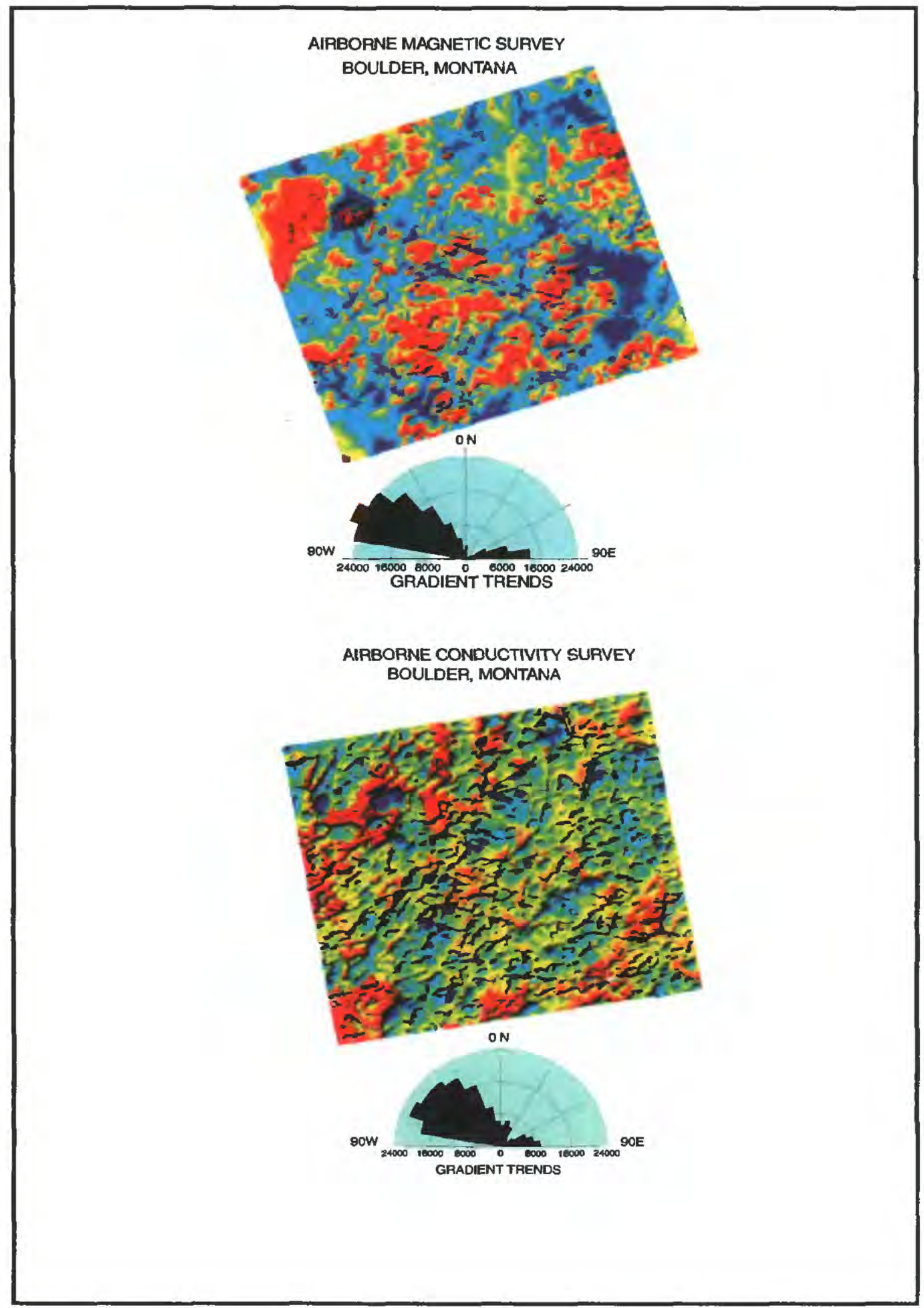

Figure 3 Color shaded relief maps of gradient trend analysis for total field magnetics (top) and 7200 Hz conductivity (bottom) 


\section{CONCLUSION}

Airborne magnetic, electromagnetic, and radiometric geophysical surveys provide subsurface information pertinent to geologic mapping, ground water flow, and physical property patterns that aid in prediction of possible contaminant pathways. The detailed information from closely spaced flight lines provides mapping information at a scale appropriate to mine site evaluation and remediation (repository location). It is important that airborne geophysical work be done early in AML studies in order that interpretational maps are made available for field use.

\section{REFERENCES}

Becraft, G.E., Pinckney, D.M., and Rosenblum, S., 1963, Geology and mineral deposits of the Jefferson City quadrangle, Jefferson and Lewis and Clark Counties, Montana, U.S. Geological Survey Professional Paper 428, $101 \mathrm{p}$.

Campbell, D.L. and D.V.Fitterman , 2000, Geoelectrical Methods for Investigating Mine Dumps, Proceedings SME meeting, Denver CO (this volume).

Cordell, Lindrith and McCafferty, 1989, A terracing operator for physical property mapping with potential field data: Geophysics, v. 54, no. 5, p. 621-634.

Desborough, G.A., P.H. Briggs, and N. Mazza, 1998, Chemical and Mineralogical Characteristics and AcidNeutralizing Potential of Fresh and Altered Rocks and Soils of the Boulder River Headwaters in Basin and Cataract Creeks of Northern Jefferson County, Montana, U.S. Geological Survey Open-File Report 98-40, $21 \mathrm{p}$.

Lee, G.K., A.E.McCafferty, B.S. Van Gosen, H.V. Alminas, V. Bankey, J.E. Elliott, D. Frishman, D.H. Knepper, D.M. Kulik, S.P. Marsh, J.D. Phillips, J.A. Pitkin, S.M. Smith, D.B. Stoeser, R.G. Tysdal, and C.A. DiFrancesco, 1999, Montana Geoenvironmental Explorer: U.S. Geological Survey Digital Data Series, 99-DDSxxx.

McCafferty, A.E., V. Bankey, and K.C. Brenner,1998, Montana Aeromagnetic and Gravity Maps and Data, U.S. Geological Survey Open-File Report 98-333.

McCafferty, A.E., B.D. Smith, T.C. Sole, S. Karl, and C.D. Taylor, 1999, Predictive Geophysical Models for Select Geologic Units and Mineralized Environments, Kuprenof and Zarembo Islands, Southeast Alaska: U.S. Geological Survey Open File Report, 99-xxx.

Ruppel, E.T., 1963, Geology of the Basin quadrangle, Jefferson, Lewis and Clark, and Powell Counties, Montana: U.S. Geological Survey Bulletin 1151, 121 p.

Shives, R.B.K., B.W. Charbonneau, and K.L. Ford, 1997, The Detection of Potassic Alteration by Gamma-Ray Spectrometry - Recognition of Alteration Related to Mineralization, p. 741-752, in-Proceedings of Exploration 97: Fourth Decennial International Conference on Mineral Exploration, Edited by A.G. Gubins, GEO/FX 1068p.

Van Blaricom, R., 1992, Practical Geophysics II for the Exploration Geologist, Northwest Mining Association, 570p. 


\title{
Chemical-Constituent Loads During Thunderstorm Runoff in a High-Altitude Alpine Stream Affected by Acid Drainage
}

\author{
Laurie Wirt ${ }^{1}$, Kenneth J. Leib ${ }^{2}$, M. Alisa Mast ${ }^{1}$, and Jonathan B. Evans ${ }^{2}$
}

\begin{abstract}
Chemical-constituent loads were determined in Prospect Gulch, a high-elevation alpine stream in southwestern Colorado that is affected by natural acid drainage from weathering of hydro-thermally altered igneous rock and acidic metal-laden discharge from historical abandoned mines. The objective of the study was to identify and quantify metal transport processes in the study reach, which contributes significant amounts of iron, aluminum, zinc, and other metals to the Cement Creek near Silverton, Colorado. A tracer solution was continuously injected into Prospect Gulch during water-quality sampling so that loading of chemical constituents could be calculated throughout the study reach. A brief rainstorm occurred during the tracer injection, hence, metal loads were measured before, during, and after storm runoff.
\end{abstract}

The late-summer storm generally increased the loads of most dissolved and total constituents higher than those observed during base-flow conditions by one or two orders of magnitude. The effects of the storm were divided into two distinct periods; (1) a first flush of higher metal concentrations that occurred soon after rainfall began and (2) the peak discharge of the storm runoff. The first flush contained the highest loads of dissolved $\mathrm{Fe}$, total and dissolved $\mathrm{Zn}, \mathrm{Cu}$, and $\mathrm{Cd}$. The larger concentrations of $\mathrm{Fe}$ and sulfate in the first flush were likely derived from iron hydroxide minerals such as jarosite and schwertmanite, which are common on mine dumps in the Prospect Gulch drainage basin. Peak storm runoff contained the highest measured loads of total iron, and of total and dissolved calcium, magnesium, silica and $\mathrm{Al}$; which were likely derived from weathering of igneous rocks and clay minerals in the drainage basin.

\section{INTRODUCTION}

From a regulatory perspective, chemical-constituent concentration and stream discharge data (used to calculate chemical-constituent "loads") are needed over a full range of hydrologic flow regimes. Base-flow conditions expose aquatic organisms to steady state or "chronic" concentrations of metals, whereas sudden changes in the flow regime can elevate concentrations of chemical constituents, exposing biota to short-term or "acute" levels of metal toxicity. Concentrations and loads of chemical constituents can change substantially with temporal and seasonal changes in stream discharge and in ground-water inflows. Unfortunately, water-quality data collected during storms is almost entirely lacking because of the difficulties in timing sample collection and personnel schedules to coincide with sudden changes in the weather, particularly in remote areas. In this paper we present what we believe may be the only chemical-constituents loads measured for an alpine stream during a late-summer thunderstorm using the tracer-dilution approach.

Prospect Gulch is a major source of iron, aluminum, zinc, and other metals to Cement Creek, a tributary of the upper Animas River in southwestern Colorado (fig. 1) that is known for its cloudy reddishorange color, high metal content, and acidity. Efforts to improve water quality by reclaiming historical abandoned mine sites have targeted Prospect Gulch. Likely sources of metals in Prospect Gulch from mining activity include flow from mine adits, surface drainage from historical abandoned mine sites, and groundwater seepage through waste-rock dumps. Metals also are derived from natural weathering of highly altered and mineralized volcanic bedrock. This study was done in cooperation with the Bureau of Land Management (BLM) in order to identify sources and relative contributions of metals in Prospect Gulch. Several historical

1 U.S. Geological Survey, Denver, Colorado

2 U.S. Geological Survey, Durango, Colorado 
mines and waste-rock dumps in Prospect Gulch are located on Federal property, and information is needed by BLM to assess the relative importance of different point sources of metals. Information on sources and loading of metals will be used to prioritize remediation and to develop strategies for cleanup of selected sites.

\section{OBJECTIVE}

Our objective was to measure chemical-constituent loads using the tracer-dilution method (Kimball, 1997) under different flow regimes to identify and quantify inflows of naturally-occurring and mining-related (anthropogenic) metals. The study area is an 800-meter reach of Prospect Gulch that includes drainage from the Lark, Henrietta, and Joe and John mine sites (fig. 2). The test was conducted during September, which generally can be expected to have low or base-flow conditions in the absence of rainfall runoff. Because of adverse weather conditions that developed during the three-hour sampling period, however, loads were measured during storm-runoff conditions as well as during base-flow conditions. More than 30 water-quality samples were collected along the study reach in Prospect Gulch and from adjacent springs and tributaries to calculate loads and identify inflows of chemical constituents.

\section{Physical setting}

Prospect Gulch is a steep-gradient mountain stream that drains the southern flank of Red Mountain No. 3 (elevation $3,930 \mathrm{~m}$ or $12,890 \mathrm{ft}$ ), shown in fig. 1 . The stream is approximately $1.5 \mathrm{mi}$ in length and joins Cement Creek one mile downstream of Gladstone. Cement Creek is a tributary of the Animas River in the San Juan Mountains of southwestern Colorado. Much of the Prospect Gulch drainage basin is above the tree line at about $3,536 \mathrm{~m}(11,600 \mathrm{ft})$. Non-forested areas consist of exposed bedrock or alpine vegetation on poorly developed soils. Average annual precipitation is about $114 \mathrm{~cm}(45 \mathrm{in})$ with $94 \mathrm{~cm}(37 \mathrm{in})$ occurring as snowfall (Sunnyside Gold Corporation, written commun., 1996, as cited in Herron et al., 1998). -

Trace metals in stream flow entering the study reach are probably derived from a mixture of drainage in contact with land disturbed by mining and natural exposures of hydro-thermally altered rocks. Two inactive mines are immediately upstream from the study reach near the creek. The study reach (fig. 2) begins just above the access road between the Henrietta mine (level Nos. 7 and 8) and the Lark mine (designated as sampling site PG-0). There are portals into at least six levels of the Henrietta mine, including the Nos. 1, 2, 3, . 7,8 , and 10 levels. The beginning of the study reach is designated as PG-0 and extends $800 \mathrm{~m}$ downstream from the tracer-injection site to a point designated as PG800 that is downstream from the waste-rock dump

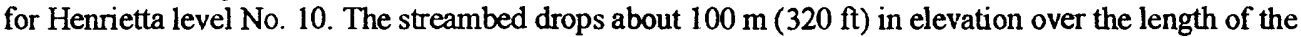
reach. Several mine sites-are immediately adjacent or within about $250 \mathrm{ft}$ of Prospect Gulch and its ephemeral tributaries.

For the first $100 \mathrm{~m}$ of the study reach, Prospect Gulch flows through an old section of the Henrietta waste-rock dump that has been mostly washed away. A small tributary enters the north side at $100 \mathrm{~m}$ that is fed by a series of seeps from a boggy area to the north that may be fault or fracture-controlled. For the next $200 \mathrm{~m}$, Prospect Gulch divides the main waste-rock dump from Henrietta mine level Nos. 7 and 8 into two sections that shall be referred to here as the north and south Henrietta waste-rock dumps. Small seeps enter the north side of the stream channel at 114, 180, 193, and $305 \mathrm{~m}$ below site PG- 0 . Large tributaries enter Prospect Gulch from the north at 286 and the south at $295 \mathrm{~m}$. These tributaries were barely flowing during reconnaissance, but carried substantial runoff during the storm the next day. From about 310 to $540 \mathrm{~m}$ the reach had no springs, no major tributaries, and little evidence of mining activities. Bedrock is exposed in the channel near $504 \mathrm{~m}$, and unlike the reach upstream, no indications of ground-water inflow were observed.

The lower part of the study reach includes the Joe and John mine site and the waste-rock dump for Henrietta level No. 10. The creek is narrow and cuts largely through bedrock in this reach. A steep ravine that drains the waste-rock dump for the Joe and John mine enters Prospect Gulch from the north side at $542 \mathrm{~m}$. A second ravine that carried flow from the Joe and John mine adit, as well as road runoff, enters the creek at $679 \mathrm{~m}$. The south bank of Prospect Gulch cuts through the toe of the waste-rock dump for the Henrietta level No. 10 from approximately 685 to $695 \mathrm{~m}$. A steep avalanche chute enters Prospect Gulch from the south below the waste-rock dump at $786 \mathrm{~m}$, and is here referred to as the Upper Henrietta tributary. The snow and debris from an avalanche were still present in this tributary at the time of the tracer study.

Relation of Water Chemistry to Drainage from Non-mined Areas and Areas Disturbed by Mining Leaching of ore and gangue minerals and dissolution of natural and mine-related soluble salts contribute substantially to the stream metal loads within the Prospect Gulch drainage basin (Bove et al., 1998). Areas up-gradient from mining activity, such as the large zone of quartz-alunite-altered breccia on the north side of Prospect Gulch, are among the most naturally degraded waters in this area. These natural waters have been measured by Bove et al. (1998) with $\mathrm{pH}$ as low as 3.3 and Ficklin Metal (FM) sums as large as 285 
micrograms per liter $(\mu \mathrm{g} / \mathrm{L})$ of $\mathrm{Cu}+\mathrm{Zn}+\mathrm{Pb}+\mathrm{Ni}+\mathrm{Co}+\mathrm{Cd}$. In contrast, waters draining the weak sericitic/propylitic margins of the acid-sulfate system are less degraded, with $\mathrm{pH}$ values from 3.4 to 3.8 and FM sums $<10 \mu \mathrm{g} / \mathrm{L}$. Waters influenced by propylitized rocks (mostly on the south side of basin) have the best water quality, on the basis of $\mathrm{pH}$ values $>6.0$ and $\mathrm{FM}$ sums $<70 \mu \mathrm{g} / \mathrm{L}$. Bove et al. (1998) suggest that calcite within these propylitically-altered rocks buffer sulfate-rich waters from local vein/breccia structures. In contrast, very little buffering occurs on the north side of the basin, where extreme acid-leaching by fluids left these rocks with inconsequential amounts of buffering material (Bove et al., 1998).

Mine-impacted waters in Prospect Gulch had FM sums more than an order of magnitude higher than their natural counterparts with a median $\mathrm{pH}$ value of 3.2 and a median FM sum of 4,300 $\mu \mathrm{g} / \mathrm{L}$. On September 15,1998 , the FM sum near the beginning of the study reach (PG45) was measured at $1,310 \mu \mathrm{g} / \mathrm{L}$. The FM sum at the end of the stuidy reach (PG800) wãs 2,000 $\mu \mathrm{g} / \mathrm{L}$. Above the confluence with Cement Creek (PGCC), the FM sum was $1,330 \mu \mathrm{g} / \mathrm{L}$. In comparison with the FM sums measured for areas where no mining is known to have occurred ( $<70$ to $285 \mu \mathrm{g} / \mathrm{L}$ ), the FM sums for stream flow in Prospect Gulch are nearly an order of magnitude higher $(1,310$ to $2000 \mu \mathrm{g} / \mathrm{L}$ ). This evidence suggests that 78 percent or more of the metals in Prospect Gulch base flow may be affected by drainage from mine adits and waste-rock dumps.

\section{METHODS AND SAMPLING PLAN}

\section{Theory of Tracer-Dilution Techniques}

Discharge was calculated at each water-sampling site in Prospect Gulch using the tracer-dilution technique. This technique was chosen because of the difficulty and the error associated with traditional dischargemeasurement techniques when used in rocky steep-gradient channels. Tracer dilution recently has been applied elsewhere to characterize metal inflows in other mountain stream reaches affected by mine drainage, including St. Kevins Gulch near Leadville (Kimball, 1997), the upper Animas River upstream and downstream from Silverton, and Cement Creek (Kimball et al., 1999; Walton-Day et al., 1999). Discharge in mountain streams can be measured very precisely by adding a salt tracer to a stream; measuring the dilution of the tracer with distance downstream; and calculating discharge from the amount of dilution (Kimball, 1997). Ninety-nine percent pure $\mathrm{NaCl}$ was used as the tracer solution because little chloride is present in the surface waters of Prospect Gulch, it is inexpensive and readily available, and has little effect on the stream environment at low concentrations. This technique is best described by the following equation:

where

$$
\mathrm{Q}_{\mathrm{s}}=\left(\mathrm{C}_{\mathrm{i}}^{*} \mathrm{Q}_{\mathrm{i}}\right) /\left(\mathrm{C}_{\mathrm{b}}-\mathrm{C}_{\mathrm{a}}\right)
$$

$\mathrm{Q}_{\mathbf{s}}=$ stream discharge, in cubic $\mathrm{ft}$ per second;

$\mathrm{C}_{\mathrm{i}}=$ tracer concentration in the injection solution, in $\mathrm{mg} / \mathrm{L}$;

$\mathrm{Q}_{\mathrm{i}}=$ rate of injection to the stream, in cubic $\mathrm{ft}$ per second;

$\mathrm{C}_{\mathrm{b}}=$ tracer concentration downstream from injection point, in $\mathrm{mg} / \mathrm{L}$; and

$\mathrm{C}_{\mathbf{z}}=$ tracer concentration upstream from injection point, in $\mathrm{mg} / \mathrm{L}$.

The tracer-dilution technique generally is used to measure base flow when streamflow is constant. In -... cases where the quantity of runoff changes, such as during a storm, the volume of discharge can still be measured quite accurately, although the loads cannot be directly compared between sites.

\section{Selection of Sampling Locations}

The day before the tracer injection, field reconnaissance was conducted in order to select appropriate tracerdilution and water-quality sample sites, to estimate stream velocity in the study reach, and to measure discharge at the outflow of the study reach. Field measurements at more than 30 sites included specific conductivity, $\mathrm{pH}$, and water temperature (Wirt et al., 1999). Station numbers were assigned according to the distance downstream from PG-0 in meters; for example, PG700 is $700 \mathrm{~m}$ downstream from PG-0. The locations for samples were selected based on tributary inflows and the surficial geology of the streambed. Specific conductivity and $\mathrm{pH}$ were used as guides when selecting samples sites in reaches where no tributaries were present. Springs and tributaries in the study reach were bracketed to obtain discharge values above and below the inflow. Subtraction of discharge at bracketed sites yields a discharge value for the corresponding tributary or spring. Discharge at the lowest site (PGCC) was measured with standard flowmetering equipment. This discharge was used to calculate the concentration of tracer solution needed in order to be detected.

\section{Field Sampling Methods}

The tracer solution was mixed with stream water to a concentration approaching saturation level the night before the injection. Samples were taken throughout the tracer study to ensure that concentration of the tracer solution remained constant. The injection apparatus included two high-capacity piston-core pumps powered by deep cell marine batteries. Tracer solution $(\mathrm{NaCl})$ was pumped from a reservoir through plastic tubing to a 
pre-pump filter capsule and then through the pump. The injection rate was monitored with a volumetric flask to ensure constant flux of 117 milliliters per minute.

On the day of the injection, an ion-selective chloride probe was deployed at site PG700 to track the arrival time of the tracer. The tracer first arrived at site PG700 at 10:40 a.m. and reached steady-state conditions at approximately 13:00 p.m. Water sampling was conducted from 12:40 to 15:48 p.m. and the pump was shut off as soon as sampling was completed. Results from the selective-ion probe were used to monitor tracer concentrations in the stream and were not used to calculate discharge as sample analysis for chloride by ion chromatograph is more accurate for this purpose.

\section{Analytical Methods}

The chloride concentrations used for tracer-dilution discharge calculations and loads were analyzed using an ion chromatograph (IC) at a USGS laboratory in Denver, Colorado. The accuracy for the discharge measurements using the tracer-dilution technique was about \pm 5 percent for low-range chloride concentrations and \pm 3 percent for high-range chloride concentrations as described in Wirt et al. (1999).

Water-quality samples were collected at all sites using standard USGS methods similar to Wilde and Radtke (1998) and Shelton (1994). Tracer-dilution samples were collected along the main channel of Prospect Gulch, while water-quality samples were collected at the tracer-dilution sample sites as well as at springs and tributaries. Filtering and processing was at the USGS field laboratory in Silverton, Colorado, using standard USGS equipment similar to Horowitz et al. (1994). All samples were processed within a 12hour time frame on the day of collection. Major cation and trace-metal concentrations in the filtered and digested whole water samples were determined by inductively coupled plasma-atomic emission spectroscopy (ICP-AES) in a USGS laboratory in Boulder, Colorado. The quality of the laboratory analyses was assessed through the analysis of laboratory blanks, sample duplicates, and USGS standard reference water samples (Long and Farrar, 1995). All field parameters and analytical data for both dissolved and total constituents are reported in Wirt et al. (1999).

\section{Timing of Weather Conditions}

As soon as the chloride concentration reached a plateau at about 13:00 p.m., water sampling started at the downstream end of the study reach and proceeded upstream. A steady rain began at about 13:40 p.m. when the sampling crew was near $500 \mathrm{~m}$. Muddy water and increasing discharge were observed at about 14:15 p.m. when sampling near $300 \mathrm{~m}$. By the time the sampling crew reached the beginning of the reach near site PG45 at 15:50 p.m., the rain had stopped and discharge apparently retumed to base-flow conditions. Thus, only those samples from site PG45 and below site PG542 were used to represent loads during base-flow conditions. For comparison at the same location, samples were collected at site TR295 before the storm (12:30 p.m.) and during the storn (14:21 p.m.).

Although loads calculated during the storm cannot be used for comparisons between different parts of the study reach, they give a qualitative indication of the magnitude and timing of changes during a storm. Because the sampling crew was moving upstream while the peak runoff was moving downstream, samples from sites PG45 through PG305 appear to be collected at a stationary location with the runoff pulse moving through, as indicated by the smooth shape of the rising and falling hydrograph (fig. 3). Discharge during the prelude to the storn appears relatively constant (PG305 to PG504), although because the sampling team was moving it is possible that discharge could have risen slightly during this early part of the stonn. As all of the peak runoff samples were collected upstream from most major tributaries, loads calculated at peak discharge are probably considerably smaller than if they had been measured at the lower end of the reach.

\section{RESULTS AND DISCUSSION}

Chemical-constituent Loads during Base-flow Conditions

Discharge increased between sites PG45 and PG700 (table 1 and fig. 4) by about 36 percent from 0.155 to 0.211 cubic feet per second $\left(\mathrm{ft}^{3} / \mathrm{s}\right)$. Over the same reach, loads for dissolved constituents increased by 740 percent for iron ( $\mathrm{Fe}), 465$ percent for aluminum $(\mathrm{Al})$, and 100 percent for sulfate $\left(\mathrm{SO}_{4}\right)$. Trace-metal loads for $\mathrm{Pb}, \mathrm{Cu}$, and $\mathrm{Zn}$ also increased 500,380 , and 50 percent, respectively. The increase in trace-metal loads through the study reach was generally more than an order of magnitude greater than the increase in base flow.

The greatest increases in metal loading occurred between sites PG45 to PG561 in the vicinity of acidic ground-water inflows from waste-rock dumps on both sides of the creek. Dissolved loads in this sub-reach increased downstream by 670 percent for $\mathrm{Fe}, 330$ percent for $\mathrm{Al}$, and 170 percent for $\mathrm{SO}_{4}$, whereas discharge increased by only about 13 percent. Trace metal loads for dissolved $\mathrm{Pb}, \mathrm{Cu}$, and $\mathrm{Zn}$ increased by 50,300, and 130 percent, respectively (table 1 and lig. 4). In the lower end of the study reach from sites PG561 to PG700, 
dissolved trace-metal loads, particularly $\mathrm{Pb}$, seemed to increase most in the vicinity of the waste-rock dump for Henrietta level No. 10. In general, trace-metal loading seemed to be greatest in the areas where source material in the form of waste-rock dump material is adjacent to the stream and opportunity is limited for attenuation of metals.

Trace-metal loads approximately a mile downstream near the mouth of Prospect Gulch (PGCC or bar " $C$ " in fig. 4) generally were substantially greater than those calculated within the study reach. Less than 6 percent of the dissolved-Fe load, 13 percent of the dissolved-Al load, and 18 percent of the dissolved- $\mathrm{Zn}$ load at site PGCC can be attributed to the study reach. Discharge at site PGCC was greater than at site PG700 by 2.4 times. Possible sources of metals downstream from the study reach include natural acidic drainage resulting from weathering of exposed altered rock, as evidenced by active ferricrete deposits and an iron bog in the reach, in addition to acid drainage that could be derived from higher-elevation areas disturbed by mining. . No large mine sites are adjacent to the stream below PG700, although the possibility of groundwater inflows affected by mining activites cannot be ruled out. In contrast with the principal study reach, the major source of metals to Prospect Gulch below PG700 is thought to be largely from naturally acidic weathering processes.

Although the major source(s) of $\mathrm{Fe}, \mathrm{Al}$, and $\mathrm{Zn}$ are apparently downstream of PG700, certain trace metals including $\mathrm{Cd}, \mathrm{Cu}$, and $\mathrm{Pb}$ seem to be disproportionately generated within the study reach. We estimate that approximately 40 percent of the dissolved (Cd) load and virtually all of the dissolved $\mathrm{Pb}$ and $\mathrm{Cu}$ loads at PGCC were probably derived from sources between PG-0 and PG700 during base-flow conditions. In fact, $\mathrm{Cu}$ and $\mathrm{Pb}$ loads actually decreased between site PG700 and site PGCC by about 20 and 75 percent, respectively. The attenuation of $\mathrm{Cu}$ and $\mathrm{Pb}$ downstream from the study reach may be the result of natural processes that cause a slight increase in $\mathrm{pH}$ from 3.2 to 3.6. For example, this attenuation may be caused by dilution from ground-water and surface-water inflows with higher $\mathrm{pH}$ or by exposure to geologic materials having a higher buffering capacity or ability to adsorb trace metals. Another possible explanation is that iron and aluminum precipitates may have removed dissolved $\mathrm{Pb}$ from solution. Different types of source contributions and different types of weathering processes appear to be responsible near the mouth of Prospect Gulch as opposed to the study reach containing several abandoned mine sites.

\section{Chemical-Constituent Loads During Storm-Runoff Conditions}

The late-summer storm on September 15, 1998 significantly increased the loads of most dissolved and suspended constituents. The timing and magnitude of changes in loads varied greatly among different groups of chemical constituents (fig. 5 and 6 ; table 1). The effects of the storm were divided into two distinct periods; (1) a first flush of higher metal concentrations that occurred soon after rainfall began and (2) the peak discharge of the storm runoff.

First Flush. An interesting phenomenon was observed in the 35 minutes between the onset of rain and the time when discharge increased rapidly. Loads of dissolved $\mathrm{Fe}$ and total and dissolved $\mathrm{Zn}, \mathrm{Cu}$, and $\mathrm{Cd}$ between sites PG504 and PG291 rise and fall before the rapid increase in runoff (fig. 5). These short-term increases in loads are the consequence of short-term increases in the concentrations of certain (but not all) chemical constituents, given that the discharge of the stream did not change substantially during this time. Total and dissolved $\mathrm{SO}_{4}, \mathrm{SiO}_{2}$, and $\mathrm{Al}$ loads also increased substantially, although loads of these constituents were higher during the period of peak runoff. Total and dissolved loads of major cations (notably $\mathrm{Ca}$ and $\mathrm{Mg}$ ) did not change substantially (table 1 and fig. 5).

These results suggest a scenario in which highly a soluble mineral dissolves and temporarily increases the concentrations of metals, referred to here as a "first flush" of salts. Because discharge did not increase significantly during the first flush, the increase in loads of dissolved constituents must be derived in or near the streambed from the dissolution of salts or near-stream pore waters having higher concentrations of metals. Miller and Drever (1977) reached a similar conclusion in a study of storm runoff in the Absaroka Mountains of Wyoming in which stream salinity increased at the onset of the storm. Drever (1982) reported how unsaturated soils generally contain salts that form when water containing dissolved ions evaporates in the soil zone. During the early part of a storm, these salts are dissolved and flushed into the stream. Later, any remaining salts carried by the runoff are diluted by the higher discharge.

Rainfall patterns may affect the concentrations of salts in the soil and the magnitude of the first flush in any given runoff event. Kennedy (1971) and Kennedy and Malcolm (1977) studied how soluble salts in the soil would be flushed by fall storms into the Mattole River of northern California. Later in the rainy season, the salts were washed out of the soil and no longer had an affect on stream chemistry. If the storm were the first storm or the most extensive storm following a period of extended dry conditions, higher loads of trace metals were likely than if the storm was in the later part of a wet season. On the day of the tracer study, 0.37 
centimeter (cm; 0.15 in) of rain fell at a nearby rain gage in Silverton. In the two weeks before the tracer study, a total of $1.65 \mathrm{~cm}(0.65 \mathrm{in})$ fell near the gage, $0.97 \mathrm{~cm}(0.38 \mathrm{in})$ falling in the three days before the tracer study (data from Colorado Climate Center, Colorado State University). Rainfall patterns often vary locally by substantial amounts, and the Prospect Gulch drainage basin may have actually received a larger or smaller amount of rainfall than was measured at the gage. In any case, either the previous storm(s) were not large enough to entirely remove the salts, or soils dried out enough for the salts to reform between storms.

The large amounts of $\mathrm{Fe}$ and sulfate in the first flush were likely derived from iron hydroxide minerals (such as jarosite $\left[\mathrm{KFe}_{3}\left(\mathrm{SO}_{4}\right)_{2}(\mathrm{OH})_{6}\right]$ and schwertmanite $\left[\mathrm{Fe}_{8} \mathrm{O}_{8}(\mathrm{OH})_{5.5}\left(\mathrm{SO}_{4}\right)_{1.25}\right]$ ), which have been identified on mine dumps in Prospect Gulch. These iron hydroxides can form under acid conditions (Bigham et al., 1996) and are secondary weathering products of iron sulfide minerals, such as pyrite. Iron hydroxides are important because they tend to strongly adsorb trace metals such as $\mathrm{Cd}, \mathrm{Cu}, \mathrm{Pb}$, and $\mathrm{Zn}$ that were released in large amounts during the first flush.

Peak Runoff. The peak runoff contained the highest loads of major constituents measured in the study reach, including dissolved and total calcium ( $\mathrm{Ca}$ ), magnesium $(\mathrm{Mg})$, and $\mathrm{Al}$ (fig. 6 and Table 1 ). Total and dissolved loads of manganese $(\mathrm{Mn})$ and silica $\left(\mathrm{SiO}_{2}\right)$ also increased substantially, and the total $\mathrm{Fe}$ load was higher than during the first flush. This increase in total Fe was consistent with field observations that the runoff became muddy with reddish brown sediment at about the same time that discharge increased rapidly. The highest load for dissolved $\mathrm{Pb}$ of 0.1 pound per day (lb/day) occurred during peak runoff, however the highest load for total $\mathrm{Pb}(0.9 \mathrm{lb} /$ day) occurred before peak runoff. In most surface waters, $\mathrm{Pb}$ tends to sorb onto particulate matter, although Hem (1992, p.143) reported that acidic waters that are poorly buffered can dissolve considerable amounts of $\mathrm{Pb}$. The dissolved $\mathrm{Pb}$ may have been leached from $\mathrm{Fe}$ hydroxides and fine-grained sediments that were suspended by the storm runoff. $\mathrm{Ca}, \mathrm{Mg}$, and $\mathrm{Al}$ were probably derived from weathering of igneous rocks and clay minerals (for example, illite and sericite) in the drainage basin.

The tributary for the Henrietta level Nos. 7 and 8 (site TR295) was sampled before and during the storm. Although concentrations of dissolved constituents generally did not change substantially, the peakrunoff loads in the tributary were generally 1 to 2 orders of magnitude higher than the loads representing base-flow conditions (fig. 6 and lable 1). Discharge in the tributary was at least 20 times higher during peak runoff. Additional work is needed to identify the specific mineral components that account for the greatest changes in water chemistry in this tributary and in the main channel during storm runoff conditions.

\section{CONCLUSIONS}

Loads for major and trace metals increased with distance downstream throughout the study reach during base-flow conditions. Not surprisingly, the increases in loads corresponded with areas where waste-rock. dumps were in close proximity to the stream and springs and tributaries are present. Chemical-constituent loads were generally higher during storm-runoff conditions than during base-flow conditions by at least one or more orders of magnitude. The highest loads during "first flush" were for dissolved Fe and most trace elements, including total and dissolved $\mathrm{Zn}, \mathrm{Cu}$, and $\mathrm{Cd}$. Loads for major elements such as total and dissolved $\mathrm{Ca}, \mathrm{Mg}, \mathrm{Al}$, and total $\mathrm{Fe}$ were greatest during the period of peak runoff.

The storm loads yielded valuable information about temporal changes in metal loads during storm runoff. In particular, the storm data indicate differences in the timing and magnitude of major-element and trace-metal loads throughout the hydrograph that is evidence of the dissolution of primary and secondary minerals in the drainage. Together, the base-flow and storm-runoff data indicate how metal loading changes in time and space over the full range of hydrologic conditions likely to occur in an alpine stream on a rainy late-summer day.

\section{REFERENCES}

Bigham, J.M., Schwertmann, Udo, and Pfab, G., 1996, Influence of pH on mineral speciation in a bioreactor simulating acid mine drainage: Applied Geochemistry, v. 11, p. 845-849.

Bove, D.J., Wright, W.G., Mast, M.A., and Yager, D.B., 1998, Natural contributions of acidity and metals to surface waters of the upper Animas River watershed, Colorado; in von Guerard P. and Nimick, D.A. eds., Science for watershed decisions on abandoned mine lands: Review of preliminary results, Denver, Colorado; February 4-5, 1998: U.S. Geological Survey Open-File report 98-297, $71 \mathrm{p}$.

Drever, J.I., 1982, The geochemistry of natural waters: Englewood Cliffs, N.J., Prentice Hall, p. 182-194. 
Hem, J.D., 1992, Study and interpretation of the chemical characteristics of natural water: U.S. Geological Survey Water-Supply Paper 2254, 263 p.

Herron, Jim, Stover, Bruce, and Krabacher, Paul, 1998, Cement Creek reclamation feasibility report, Upper Animas River Basin: Denver, Colo., Colorado Division of Minerals and Geology, 137 p.

Horowitz, A.J., Demas, C.R., and Fitzgerald, K.K., 1994, U.S. Geological Survey protocol for the collection and processing of surface-water samples for the subsequent determination of inorganic constituents in filtered water: U.S. Geological Survey Open-File report 94-539, 157 p.

Kennedy, V.C., 1971, Silica variation in stream water with time and discharge, in Nonequilibrium systems in natural water chemistry, American Chemical Society Advanced Chemistry Series 106, p. 94-130.

Kennedy, V.C., and Malcolm R.L., 1977, Geochemistry of the Mattole River of northern California: U.S. Geological Survey Open-file report 78-205, 324 p.

Kimball, B.A., 1997, Use of tracer injections and synoptic sampling to measure metal loading from acid mine drainage: U.S. Geological Survey Fact Sheet 245-96, 4 p.

Kimball, B.A., Runkel, R.L., Bencala, K.E., and Walton-Day, Katherine, 1999, Use of tracer-injection and synoptic-sampling studies to quantify effects of metal loading from mine drainage, in Morganwalp, D.W., and Buxton, H.T., eds., U.S. Geological Survey Toxic Substances Hydrology ProgramProceedings of the Technical Meeting, Charleston, South Carolina, March 8-12, 1999: Volume 1Contamination from hardrock mining: U.S.-Geological Survey Water-Resources Investigations Report 99-4018A, in press.

Long, H.K. and Farrar, J.W., 1995, Report on the U.S. Geological Survey's evaluation program for standardreference samples distributed in May 1995-T-135 (trace constituents), M-134 (major constituents), N-45 (nutrients), N-46 (nutrients), P-24 (low ionic strength), Hg-20 (mercury), and SED-5 (bed material): U.S. Geological Survey Open-File Report; 95-395, 135 p.

Miller, W.R., and Drever, J.I., 1977, Water chemistry of a stream following a storm, Absaroka Mountains, Wyoming: Geological Society of America Bulletin, v. 88, p. 286-290.

Nash, J.T., 1999, Geochemical Investigations and Interim Recommendations for Priority Abandoned Mine Sites, BLM Lands, Upper Animas Watershed, San Juan County, Colorado U.S. Geological Survey Open-File report 99-323, 45 p.

Shelton, L.R.,-1994, Field guide for collection and processing stream-water samples for the National WaterQuality Assessment Program: U.S. Geological Survey Open-File Report 94-455, 42 p.

Walton-Day, Katherine, Runkel, R.L., Kimball, B.E., and Bencala, K.E., 1999, Application of the solutetransport models OTIS and OTEQ and implications for remediation in a watershed affected by acid mine drainage: Cement Creek, Animas River Basin, Colorado, in Morganwalp, D.W., and Buxton, H.T., eds., U.S. Geological Survey Toxic Substances Hydrology Program-Proceedings of the Technical Meeting, Charleston, South Carolina, March 8-12, 1999: Volume 1-Contamination from hardrock mining: U.S. Geological Survey Water-Resources Investigations Report 99-4018A, in press.

Wilde, F.D., and Radtke, D.B., 1998, National field manual for the collection of water-quality data: U.S. Geological Survey Techniques of Water-Resources Investigations, book 9, chap. A6, sections $6.0,6.0 .1,6.0 .2,6.0 .2 . A$, and 6.0.2B.

Wirt, Laurie, Leib, K.J., Bove, D.J., Mast, M.A., Evans, J.B., and Meeker, G.P., 1999, Determination of chemical-constituent loads during base-flow and storm-runoff conditions near historical mines in Prospect Gulch, Upper Animas River Watershed, Southwestern Colorado: U.S. Geological Survey Open-file report 99-159, 39 p. hitp://grecnwood.cr.usgs.gov/pub/open-file-rcports/orr-99-() 159/ 


\title{
Natural Versus Mining-Related Water Quality Degradation to Tributaries Draining Mount Moly, Silverton, Colorado
}

\author{
Douglas B. Yager', M. Alisa Mast ${ }^{2}$, Philip L. Verplanck', Dana J. Bove ${ }^{1}$, Winfield G. Wright ${ }^{4}$, \\ and Philip L., Hageman'
}

\begin{abstract}
Geological, hydrological, and geochemical information synthesized in a Geographical Information System (GIS) for water and rock surrounding South and Middle Forks of Mineral Creek, northwest of Silverton, Colorado, was analyzed to distinguish between the natural and the mining-related sources of metals to surface waters in the watershed. An important natural source of metals to surface water emanates from a porphyry molybdenum deposit south and upslope from the Middle Fork of Mineral Creek. Interaction of surface and ground water with fractured, altered rocks and permeable, Quatemary-age surficial deposits produces downstream water quality that does not meet current State of Colorado water quality standards for metals and $\mathrm{pH}$. GS site characterization and three-dimensional modeling distinguish surficial deposits as volumetrically substantial, significant sources of naturally occurring metals that strongly influence.water quality and complicate ongoing mine-site mitigation efforts. Our findings indicate that regional hydrologic and geologic information needs to be evaluated before realistic water-quality guidelines are established and mitigation recommendations are confidently implemented.
\end{abstract}

\section{INTRODUCTION}

The red, yellow, and white precipitates from water draining hydrothermally altered rock are strong visual indications of poor water quality in non-mining-affected tributary basins near Silverton in southwestern Colorado. Mining in this region has disturbed the natural ecosystem and has further degraded water quality. One important question that needs to be addressed in mined regions is "what are the environmental effects of mineralized but unmined areas compared to the environmental effects related to mining?'--The answers to this question are important because the water quality in a mined watershed will depend not only the miningrelated, but also on the non-mining-related geochemical loading sources. The strategies used to address this question in our study included: (1) collecting geochemical, mineralogic, and hydrologic data in headwater stream-reaches that are not affected by mining, (2) synthesizing all data collected into a GIS, (3) GIS modeling to aid in the identification of major- and trace-element sources to surface water, (4) threedimensional modeling of a volumetrically important surficial deposit that was identified to adversely affect the watershed, and (5) performing field-leach tests, using the method of Hageman and Briggs (this volume) on both non-mining-affected surficial deposits composed of altered rock, and on mine wastes located on the periphery or downslope from the headwater stream reaches. Field-leach tests were performed to gain some understanding of the acid-generating potential of the non-mining-affected surficial deposits for comparison with mine wastes.

The occurrence of pervasively altered and mineralized country rock in mining districts complicates the determination of factors that contribute to water quality. Data integration for mineralized but unmined sites at the headwater regions of a watershed provides an indication of the geochemical baseline conditions that exist today and provides insight into what the geochemical backgound conditions were prior to mining (Miller, 1998). Information collected in non-mining-affected regions may be compared with areas affected by mining to better understand what restoration goals are achievable. Data synthesis in a GIS permits the simultaneous

\footnotetext{
${ }^{1}$ U.S. Geological Survey, PO Box 25046, Denver Federal Center, Mail Stop 973, Denver, Colorado 80225

2 U.S. Geological Survey, PO Box 25046, Denver Federal Center, Mail Stop 939, Denver Colorado 80225

${ }^{3}$ U.S. Geological Survey, 3215 Marine Street, Boulder, Colorado 80303

${ }^{4}$ U.S. Geological Survey, 103 Sheppard Drive, Durango, CO 81301
} 
visualization of the relationships among acidic and metal-rich waters, altered rocks, and Quaternary deposits in both mined and unmined areas. Once the geospatial relationships in the GS are evaluated, understood, and quantified, then these data may be used by Federal agencies and local stakeholder groups in making better informed decisions about mined land restoration.

\section{SITE DESCRIPTION}

The study area is in the rugged and spectacular San Juan Mountains between South and Middle Forks of Mineral Creek (Figure 1). Topographic relief in the study area reaches $1,000 \mathrm{~m}$ and the elevation reaches over $4,000 \mathrm{~m}$ above sea level. The ecoregion is classified as the Southern Rocky Mountain Steppe (Bailey, 1995).

\section{Geologic Setting}

The general stratigraphy of the region consists of a Precambrian crystalline basement overlain by Paleozoic and Mesozoic sedimentary rocks and by a Tertiary volcanic cover (Luedke and Burbank, 1963; Steven, et al., 1974;-Lipman, et al., 1973; Luedke and Burbank, 1987; Luedke and Burbank, 1996). Tertiary volcanism in the San Juan Volcanic Field began about $35 \mathrm{Ma}$ with the eruption of intermediate composition lavas, pyroclastic flows, and mudflows. The oldest Tertiary volcanics, the San Juan Formation (SJF), consist primarily of mudflows and pyroclastic flows with subsidiary lava flows. The change in tectonic regime from Laramide compression to Tertiary extension coincides with a shift in style of volcanism that is characterized by catastrophic eruption of silicic magma-forming calderas (Lipman, et al., 1972). Locally, these are the San Juan caldera (28.2 Ma) followed by the nested Silverton caldera (27.6 Ma) (Lipman et al., 1976; Bove et al., 1999).

Caldera-forming arcuate ring fractures and tangential radial fractures preserved near the periphery of the calderas provided pathways for intrusive magmas and later hydrothermal fluids and ore deposition (Figure 1) (Varnes, 1963; Burbank and Luedke, 1969; Casadevall and Ohmoto, 1977). These Tertiary, volcano-tectonic structures occur as regionally pervasive features with lengths that extend for thousands of meters. Grabens formed in the central cores of the calderas in response to resurgent magma, which domed and faulted the overlying volcanics. The grabens were later extensively mineralized (Casadevall and Ohmoto, 1977). San Juan caldera collapse was followed by eruption of post-collapse, intermediate-composition Silverton Volcanic Series (SVS) lava flows that infilled the San Juan caldera (Lipman, 1973). The SVS volcanics contain much of the mineralization in the upper Animas River watershed (ARW).

Porphyry intrusions that are intermediate to silicic in composition have intruded the SJF and SVS rocks along the southwest margin of the Silverton caldera (Figure 1). The oldest and least evolved intrusions are the 26.6 Ma Sultan Mountain and the $25 \mathrm{Ma}$, Mount Moly ${ }^{5}$ stocks.(Lipman et al., 1976;-Ringrose, 1982; Bove et al., 1999). These stocks are part of a monzonitic intrusive event that-resulted in hydrothermal alteration and cogenetic mineralization that produced a low grade, porphyry-style molybdenum deposit in the study area (Ringrose, 1982).

Regional tilting and uplift in the San Juan Volcanic Field during latest Miocene to Pleistocene time (Steven, 1996), along with extensive glaciation has caused erosion and downcutting to expose a mineralized and hydrothermally altered terrain. Acid rock drainage to surface water throughout the upper ARW is likely in part caused by the geologically recent, accelerated exposure by weathering and erosion of the hydrothermally altered rocks that has taken place in the San Juan Volcanic Field over the last 4 to $5 \mathrm{Ma}$ (Steven, 1996).

\section{Geology and Mineralogy of the Study Area}

Older SJF and only remnants of the SVS lavas are preserved within the study area. A prominent peak, locally referred to as Mount Moly, marks the center of the study area (Figure 2A). The study area was chosen because: (1) water quality sampling could be done in areas that are unaffected by mining and (2) it displays similarities to a typical low-grade, Mo-Cu porphyry with a mineralogically zoned alteration profile. A typical porphyry ore deposit is zoned from a potassic central core, outward through a halo of quartz-sericite-pyrite to a zone of propylitic alteration (chlorite-epidote-calcite)(Guilbert and Lowell, 1974).

The caldera-related faulting that characterizes the central core of the Silverton caldera is not so extensive in the study area. Mineralized faults and fracture systems, however, that are sub-parallel or tangential to the caldera structural margins do occur (Figure 2A). Base-metal sulfide vein mineralization that developed near

\footnotetext{
${ }^{5}$ Previous workers refer to a prominent peak labeled 12,442 on the Silverton, 1:24,000-scale topographic map as "Mount Moly" (Ringrose, 1982).
} 
the periphery of the Mo-Cu porphyry and along the fracture systems was mined in the late $19^{\text {th }}$ century. Minerals associated with the base-metal veins include sphalerite, tetrahedrite-tennantite, galena, and pyrite (Ringrose, 1982). Field-leach data on the only major and several of the minor mines is presented below and compared with field-leach data collected from non-mining-affected surficial deposits.

Although faults are not prevalent in the study area, the rocks are highly jointed. Up to eight fracture sets were recognized at a given outcrop (Ringrose, 1982). The prevalent joints aid in accelerating the freeze-thaw weathering process, which continually exposes fresh rock surfaces to water-rock interaction. Well-developed joint sets, oriented sub-parallel to slope, that dip $10^{\circ}$ to $30^{\circ}$ to the southeast or northwest are observed throughout the study area. These shallow-dipping joints may serve as efficient flow paths near the surface.

\section{Hydrothermal Alteration}

The major alteration zones in the study area are depicted in Figure 1. An intense zone of alteration is centered near Mount Moly and is characterized by stockwork, quartz-pyrite-molybdenite veinlets, in a bleached-white, quartz-sericite-pyrite (Q-S-P) altered host rock, with jarosite- and goethite-stained surfaces (Figure 1). As much as 5 volume percent pyrite occurs in core samples drilled near the Mount Moly summit in the Q-S-P zone. The next alteration halo is composed of patches of sericitic plus minor argillic alteration. The mineral assemblage in this zone is composed of patchy occurrences of Q-S-P alteration; the presence of kaolinite is used to identify the argillic assemblage. The most intense zone of alteration consists of masses of quartz, andalusite, pyrophyllite, and pyrite, which is characteristic of a high-temperature, potassic hypogene mineralization event (Henley and McNabb, 1977). This potassic assemblage is located in the midst of a pervasive sericitic alteration zone southeast of the Mount Moly summit (Ringrose, 1982) and was also identified in areas southwest of the Mount Moly summit by the first author. An aureole of propylitic plus pyrite alteration is found outward from the transitional sericitic zone. The periphery of the alteration is characterized by a propylitic assemblage composed of chlorite, epidote, \pm calcite, \pm pyrite, illite, and opaque oxides. Outward from the Mo-Cu porphyry-related propylitic assemblage, a regional propylitic event is recognized that has affected most igneous rocks of Tertiary age in the upper ARW (Burbank and Luedke, 1969).

\section{ANALYTICAL METHODS}

\section{Geochemical, Mineralogic, and Field-Leach Analyses}

Whole-rock samples were collected from each alteration assemblage throughout the study area and analyzed by the ICP-MS method at a U.S. Geological Survey laboratory to determine trace-element abundances (Table 1) and by X-ray diffraction to characterize alteration mineral assemblages. The toe and upper surface of the north-slope Mount Moly debris fan were sampled using a 2-meter stainless steel soil auger to determine the mineralogy of part of the fan. Water-saturated auger samples were air-dried for later passive-leach and X-ray diffraction analysis (Table 2).

Surface water and springs were sampled in the Mineral Creek tributaries in the summer and fall from 1995 to 1998 (Mast et al., this volume).

A field-leach test (Hageman and Briggs, this volume) and passive-leach studies (Fey et al., this volume) were used to compare the acid generating potential of mine wastes and non-mining-affected surficial deposits in the study area and in one other location in the upper ARW.

The mine wastes were collected from three sites located downstream from or near the periphery of the Red Tributary study area (Figure 2C) using the 30-cell composite sampling method described in Hageman and Briggs (this volume). Only the Bonner mine has recorded mineral production. The other two mines sampled, the Paradise Portal and the Ruby Trust mines, which are located in areas that drain into the Middle Fork of Mineral Creek (Figure 2C), do not have known mineral production. The Bonner Mine adits were constructed to exploit base-metal veins that formed along a northeast-southwest-oriented structural zone in propylitic host rocks of the SJF. The Paradise portal appears to have been driven beaneath a ferricrete deposit amongst propylitic to weakly sericitic rocks of the SJF that eventually intersected Q-S-P altered rocks. The Ruby Trust mine adit was constructed in propylitic rocks of the SJF.

Locations of non-mining-affected surficial deposits sampled for the field-leach test include: (1) the north slope Mount Moly debris fan (Figure 2B), (2) a colluvium deposit derived predominantly from weakly sericitic and propylitized rocks located $0.4 \mathrm{~km}$ downstream from the north slope Mount Moly debris fan and north of the Red Tributary, and (3) an additional non-mining-affected debris fan located about $1.4 \mathrm{~km}$ north of Silverton, upslope and to the east of Mineral Creek. 


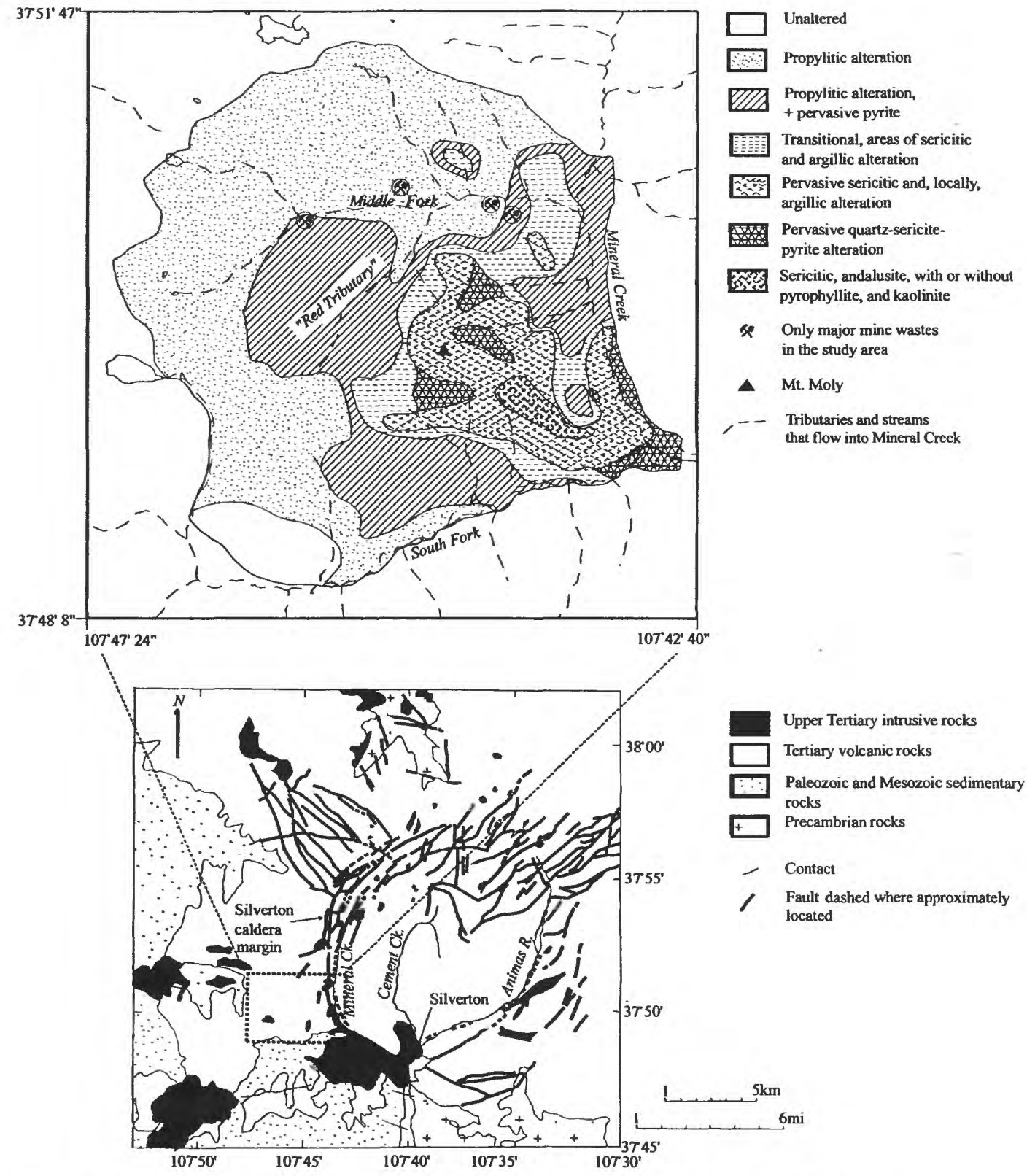

Figure 1 Generalized regional geologic map near the study area (below). Study area shown by dot outlined box. Enlarged ARC/INFO GIS coverage (above) of the study area that indicates the spatial relationships between zoned alteration patterns (Ringrose, 1982), mines, and tributaries of Middle and South Forks that flow into Mineral Creek. Alteration pattern contacts are gradational. 


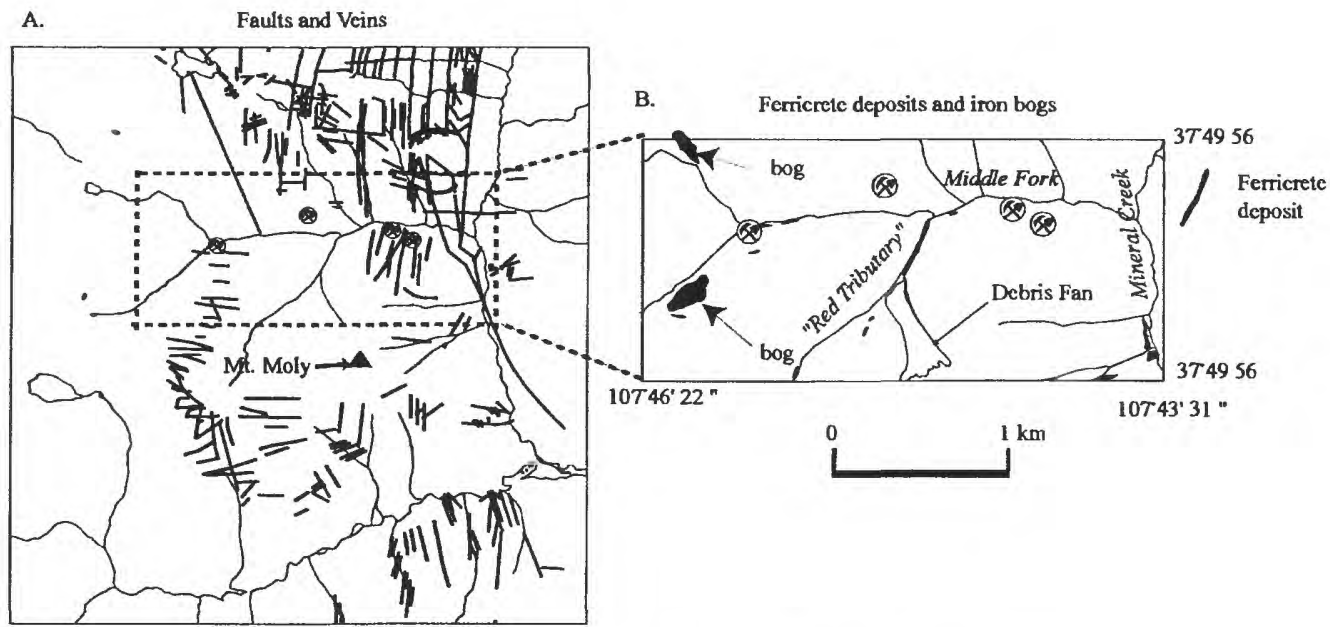

c.
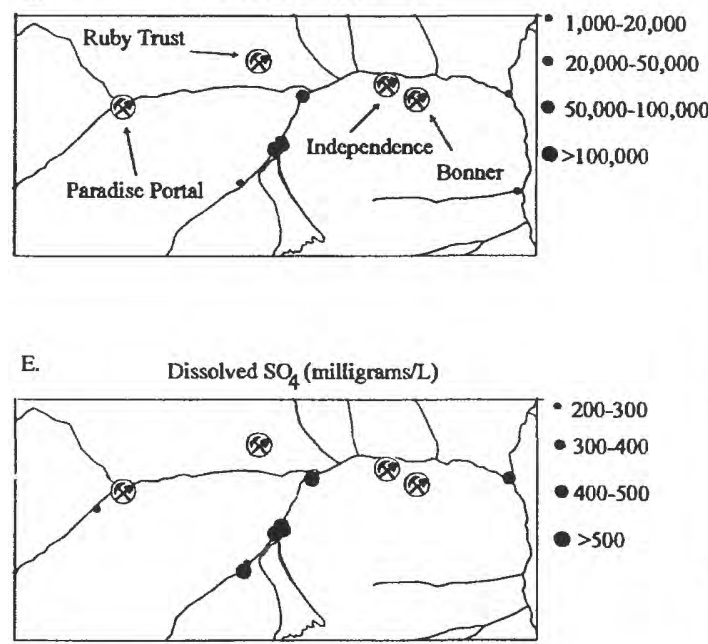

G.

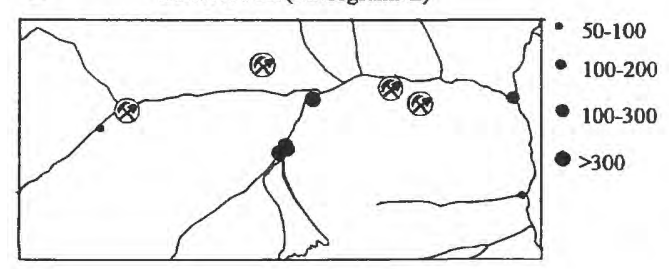

D. Dissolved Al (micrograms/L)

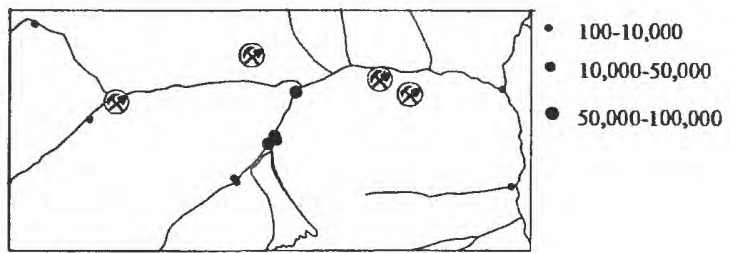

F.

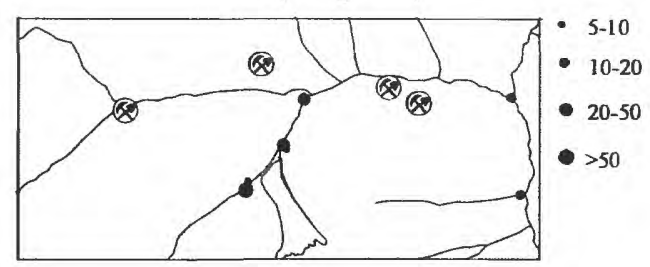

H.

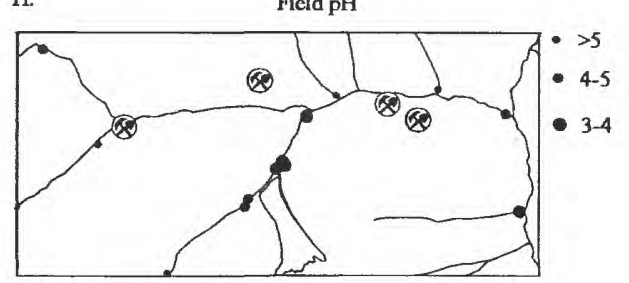

Figure 2 ARC/INFO GIS coverages for faults and veins (A), ferricrete and iron bogs (B), proportional dot maps (symbol size increases with increasing concentration) of stream geochemical analyses for dissolved iron, aluminum, sulfate, copper, zinc, all in micrograms/L except for sulfate reported in mg/L (C thru G). Field pH (H). Mines are indicated with the "pick and shovel" symbol. North-slope debris fan is indicated in (B). 
These surficial deposit sites were chosen because they are representative of non-mining-affected areas that were derived from rocks that have varying intensities of alteration. Intense alteration is present upslope from both of the debris fans sampled.

GIS and Spatial Modeling

A GIS database was constructed using $\mathrm{ARC} / \mathrm{INFO}^{6}$ software to analyze the spatial relationships between surface-water-quality data (Mast et al., this volume) in addition to alteration mapping (Ringrose, 1982), mine location, and geologic structure information. The resultant GIS map products are visually intuitive and permit the identification of sites where surface water is adversely affected by mines, altered rocks, and surficial deposits derived from altered areas. A subset of our GIS database (Figure 2; Yager, 1999) provides waterquality information for a non-mining-affected stream reach designated as the "Red Tributary" for this study. The Red Tributary is located below the north slope of Mount Moly (Figure 2B) and is informally named for the over 1-m-thick ferricrete ${ }^{7}$ that is composed of reddish-hued, iron, oxyhydroxide precipitates on and adjacent to the streambed near its confluence with the Middle Fork of Mineral Creek (Figure 2B). This GIS database and spatial modeling approach differs from the more traditional graphical display of data and from the time-intensive manual cartographic mapping techniques. GIS data items may be rapidly added or subtracted to soft-copy map views and hard-copy maps that are printed and brought to the field to compare and contrast various pertinent data. GIS thematic proportional dot maps (larger dots represent higher concentrations or higher values, Figure 2) were constructed to show where metals, $\mathrm{pH}$, and sulfate do not meet State of Colorado recommended stream standards (Colorado Department of Health, 1984). Analysis of the GIS maps helped further guide field studies in the Red Tributary.

Due to the close correspondence between low $\mathrm{pH}$ and high major- and trace-element concentrations near the north slope Mount Moly debris fan, a three-dimensional model of the fan was constructed with Earth Vision software (Figure 3). The model constructed aided in calculating the volume of the deposit. A 10meter-resolution digital elevation model (DEM) and an ARC/INFO digital coverage of the debris fan were imported into Earth Vision to construct the model. A thickness of 5 meters was subtracted from every DEM cell that was located inside the debris fan coverage boundary. Field observations indicate that the fan thickness is greater than 5 meters in many locations. The resultant volume subtracted from the DEM was used to determine the fan volume.

\section{RESULTS AND DISCUSSION}

\section{Effect of Hydrothermal Alteration on Surface-Water Quality}

Water-quality data integrated into a GIS indicate where altered rocks, which have minimal buffering capacity, affect the Red Tributary waters. These data also show the spatial relationship between acidic majorand trace-element-rich Red Tributary surface water and the north slope Mount Moly debris fan.

Propylitically altered rocks crop out in the headwater reaches of the Red Tributary. Water-quality samples collected from sites that intersect the propylitic zone have higher $\mathrm{pH}$ values, and with the exception of sulfate, lower major- and trace-metal concentrations. Rocks in the headwater reaches of the Red Tributary likely have significant buffering capacity. Permeability, primarily due to the clastic and fractured nature of the volcaniclastic SJF rocks, combined with the presence of calcite $\left(\mathrm{CaCO}_{3}\right)$ and secondary hydrous alteration phases such as chlorite (Desborough et al., 1998), supply the buffering capacity. Water-quality samples collected downstream have lower $\mathrm{pH}$ values and higher major- and trace-element concentrations where waters have intersected zones of more intensely altered rocks (Figure 2). An increase in dissolved Fe, $\mathrm{Al}, \mathrm{Zn}$, and lower $\mathrm{pH}$ are observed where Red Tributary waters flow adjacent to the north slope debris fan (Figure 2). The north slope debris fan is composed of rocks that were weathered from the quartz-sericitepyrite alteration assemblage. The debris fan appears to function as a porous flume for water rock interaction. Surface and shallow ground-water reacts with the minerals in the fan, including pyrite, which increases acidity and further degrades water quality along the Red Tributary. All of the aforementioned observations are related to a stream reach of the Red Tributary that is located upstream from any mining activity.

\section{Geochemical Composition of Whole Rocks}

The highest trace-element anomalies were observed in veins on the east slope of Mount Moly (Table 1).

\footnotetext{
${ }^{6}$ Any use of trade names, product, or firm names, is for descriptive purposes only and does not imply endorsement by the U. S. Geological Survey.

${ }^{7}$ Ferricrete is a term used to describe a conglomerate that has been cemented by iron oxide derived from the oxidation and precipitation of Fe-rich solutions (Lamplugh, 1902).
} 


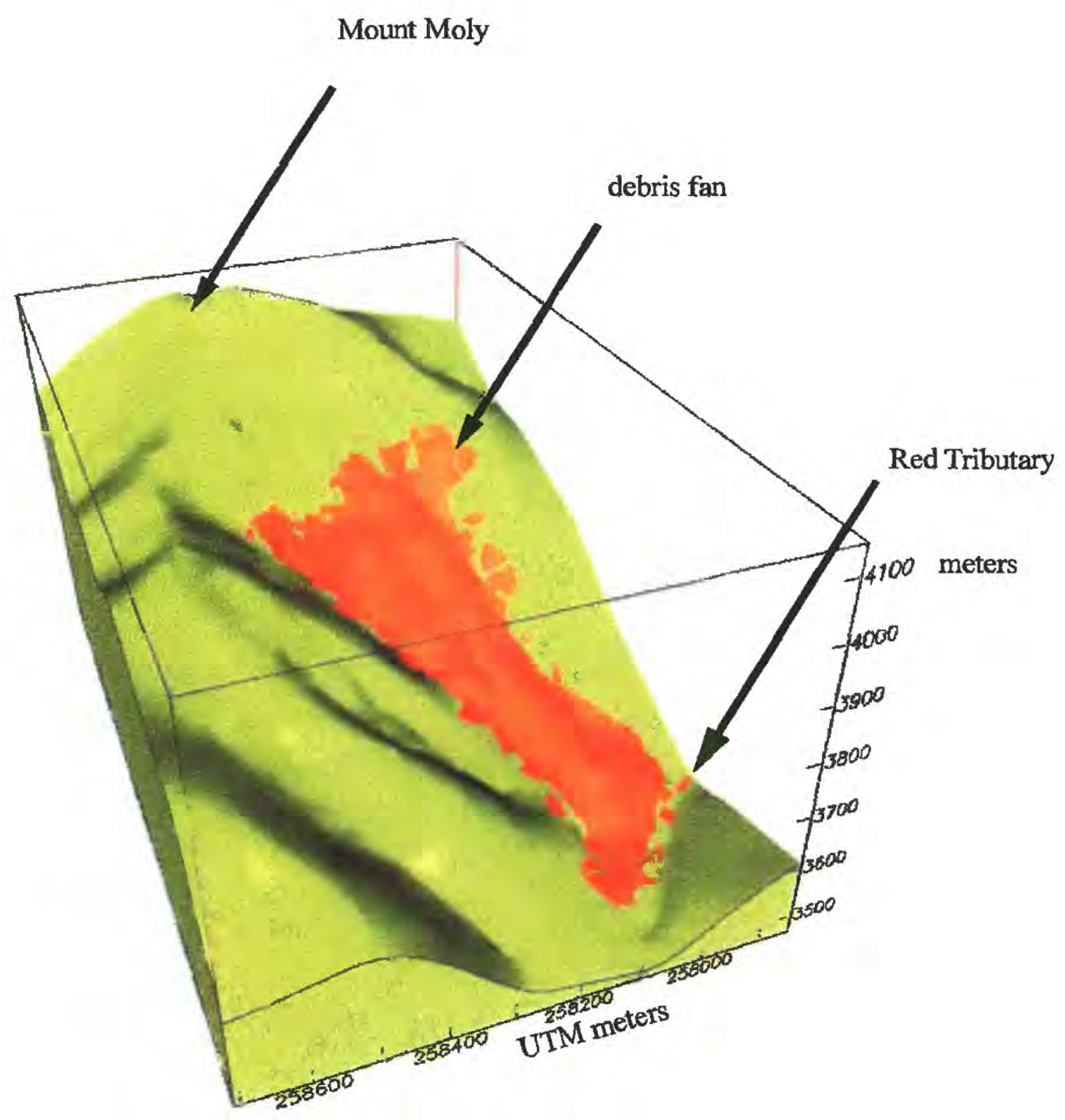

Figure 3 Two-dimensional rendering of a three-dimensional model for the north-slope Mount Moly debris fan. View is to the southwest. 
Copper concentrations in rocks range from 6 to $1,200 \mathrm{ppm}$, exceeding average crustal abundances (Fortescue, 1992 ) by 11 to 17 times. Molybdenum concentrations range from 2 to $1,700 \mathrm{ppm}$, which exceeds crustal abundances from 2 to 1,700 times. Lead concentrations range from 11 to 37,000 ppm, which exceeds crustal abundances by as much as 2,800 times. These data are indicative of why the Mount Moly area was a target for mineral exploration in the 1970's.

\section{GIS Maps Depicting Stream Toxicity}

GIS was successfully used to integrate stream-water quality and bedrock alteration information (Figure 1) in addition to geologic structures, mine site, and surface-water-quality data (Figure 2). The surface-waterquality GS maps indicate where current water-quality standards are not met. The maps show where dissolved $\mathrm{Fe}, \mathrm{Al}, \mathrm{Cu}, \mathrm{Zn}$, and $\mathrm{SO}_{4}$, and $\mathrm{pH}$ all do not meet the State of Colorado recommended class 1 aquatic-life criteria for waters with a hardness of $100 \mu \mathrm{g} / \mathrm{L} \mathrm{CaCO}$ (Figure 2, C-H). The Red Tributary has elevated Fe concentrations (1,000 to over $100,000 \mu \mathrm{g} / \mathrm{L}$ ) (Mast et al., this volume) exceeding by 100 times the class 1 aquatic-life criteria (Colorado Department of Health, 1984). Although high iron concentrations are now recognized as potentially having an adverse effect on aquatic life (Nordstrom et al., 1999), the toxic effects of iron on aquatic life is less well known than for some other metals such as copper and zinc. Iron was recently identified as causing toxicity for Ceriodaphnia dubia based on tests run on metalliferous mine sediment pore waters (Nordstrom et al., 1999).

Aluminum concentrations range from 100 to over $70,000 \mu \mathrm{g} / \mathrm{L}$, which exceeds the State of Colorado recommended aluminum allowance $(100 \mu \mathrm{g} / \mathrm{L})$ for waters that have a hardness of $100 \mu \mathrm{g} / \mathrm{L} \mathrm{CaCO}$ (Colorado Department of Health, 1984). Chronic toxicity levels for aluminum in waters have been found to be as low as 1,900 and 3,280 $\mathrm{gg} / \mathrm{L}$ for Ceriodaphnia dubia and fathead minnows, respectively (USEPA, 1988). Figh concentrations of aluminum in the Red Tributary emanate from propylitic to weakly sericitic and Q-S-P alteration zones upstream. Aluminum is likely leached from ubiquitous chlorite and also from illite present in altered primary phases and in the matrix of propylitized and Q-S-P altered host rocks.

\section{Non-Mining-Affected Surficial Deposits and Their Potential Effect on Water Quality}

Much emphasis is appropriately placed on the effect past mining activity has had on the ARW. Perhaps overlooked, but important flow-paths for waters, however, are non-mining-affected surficial deposits that are derived from altered source rocks. The north slope Mount Moly debris fan located near the Red Tributary is one such deposit that is composed predominantly of quartz-sericite-pyrite altered rocks with secondary jarosite- and goethite-stained surfaces and weakly sericitic altered rocks with pervasive, fine-grained, disseminated pyrite. Samples were collected from the base of several north slope debris fan auger holes near where surface waters have dissolved iron concentrations $>\cdot 100,000 \mu \mathrm{g} / \mathrm{L}$ (Figure $2 \mathrm{C}$ ). The samples collected have a yellow to brownish-yellow hue (10YR-8/8 to 10YR 6/8, Munsell Soil Color Chart). X-ray diffraction analyses of auger cuttings collected from the debris fan were used to confirm the occurrence of schwertmannite with subsidiary amounts of \pm goethite, clinochlore, jarosite, muscovite, and quartz (Table 2 ). The thickness and lateral extent of the deposit are unknown due to the limitations of the manual augering equipment and the development of a 1-meter-thick soil zone that obscures the schwertmannite-bearing deposit beneath.

Schwertmannite $\left[\mathrm{Fe}_{16} \mathrm{O}_{16}(\mathrm{OH})_{9.6}\left(\mathrm{SO}_{4}\right)_{3.2} \bullet 10 \mathrm{H}_{2} \mathrm{O}\right]$ is a recently identified mineral (Bigham et al., 1994; Schwertmann et al., 1995) that forms under acidic conditions in both mined and natural mineralized settings. The anionic charge potential and high surface area (Bigham et al., 1994) make schwertmannite a potential adsorption site for metal cations. Mixtures of schwertmannite and goethite $(\alpha-\mathrm{FeOOH})$ precipitate from acidsulfate waters at a pH range between 2.6 and 4, whereas the sulfate mineral jarosite $\left[(\mathrm{H}, \mathrm{K}, \mathrm{Na}) \mathrm{Fe}_{3}(\mathrm{OH})_{6}\right.$ $\left.\left(\mathrm{SO}_{4}\right)_{2}\right]$ forms at a $\mathrm{pH}$ near 2.6 (Bigham et al., 1996). The north slope debris fan appears to be a major source of metals and sulfate loading to the Red Tributary (Mast et al., this volume).

Analysis of GS coverages (Figures 2C, D, E, G, and H) indicate that acidic and metal-rich waters strongly correlate with the location of the north slope Mount Moly debris fan. Other surficial deposits located throughout the ARW that are derived from altered rocks will likely interact with waters in a similar way to that observed in the north slope Mount Moly debris fan. These deposits are porous and permeable due to their clastic nature and provide ample opportunity for water-rock interaction.

\section{Field-Leach Test and Passive-Leach Experiments on Surficial Deposits and Mine Wastes}

Field- and passive-leach tests were completed to provide an indication of the acid-generating potential of the non-mining-affected surficial deposits as compared to mine wastes located near the Red Tributary (Table 3). The field-leach and passive-leach tests do not directly represent the acid-producing conditions of mine wastes and surficial deposits in nature. These tests, however, do provide some indication of the acid-generating 
potential of these types of deposits. Three of the surficial deposits sampled generated acidity in the leach tests. The lowest pH observed was in the auger cutting material collected at the base of the north slope Mount Moly debris fan. A field-leach test performed on a colluvium-derived deposit, sample SDY9913, located just downstream and to the north of the Red Tributary, had a resultant $\mathrm{pH}$ that approximated that of deionized water. The colluvium was weathered from an upslope source of propylitic and weakly sericitic rocks that likely have significant buffering capacity due to the presence of chlorite (Desborough et al., 1998). Specific-conductance measurements collected from surficial deposit surfaces are generally lower than those observed for mine wastes. Low conductivity measurements observed in field-leach tests for the north slope debris fan suggest that acidic conditions are enhanced with sustained water-rock interaction as initially acidic water moves toward the toe of the fan. Acidic conditions and higher metal concentrations are attained as water flows throughout the fan and reacts with acid-generating minerals such as pyrite.

Field-leach tests on mine wastes in the region generally indicate lower $\mathrm{pH}$ and higher specificconductance as compared with the surficial deposits. Propylitic host rocks that are prevalent in regions where base-metal veins were mined may supply some buffering capacity and may help explain some of the low specific conductance measurements observed for the Bonner and Ruby Trust Mines. Differences in specificconductance values between mine wastes and surficial deposits are partly caused by the concentrated nature of sulfide minerals in mine wastes as compared with the more diffuse presence of sulfides in surficial deposits.

\section{Three-dimensional modeling of the north slope debris fan}

In light of the acid-generating potential of the north slope Mount Moly debris fan, and due to its close spatial relationship to stream inputs of major and trace elements, a three-dimensional model of the fan was constructed (Figure 3) with use of Earth Vision software. The three-dimensional model provides a simple tool to calculate the debris fan volume and thus compare the results to volumes for selected mine wastes in the upper ARW. Such analyses are important because the debris fan material will generate acidic major- and trace-element-rich waters long after remediation of mine wastes is achieved.

A conservative estimate of the volume of material in the fan is $\sim 500,000 \mathrm{~m}^{3}$. Further quantification of the abundances of pyrite and other acid-producing phases in the fan will help determine the potential effect that the debris fan will have on water quality in the future. Average mine-waste-pile volume estimates in the ARW are below $10,000 \mathrm{~m}^{3}$ (Herron et al., 1998). Land managers may find volume comparisons between surficial deposits and mine wastes useful to consider when they evaluate what restoration goals are achievable in a watershed. Restoration work on mine wastes may improve water quality locally, however, where surficial deposits derived from altered rocks are present upstream from remediated sites, their effect on water quality may be large and ongoing long after mine waste remediation activity is completed.

A direct comparison between the affect that debris fans derived from altered rocks and mine wastes will have on surface water is an oversimplification because of the differences in grain size and clast sorting and in the percentage of sulfides in the two deposit types. Dispersed distribution of metals and water-quality degradation associated with debris fans derived from mineralized terrain is quite variable when compared to the concentrated, point-source nature of metals in mine wastes. Field and passive-leach experiments nonetheless indicate that minerals present in the debris fans have a potential to generate acidity and contribute major and trace elements into the ARW.

\section{CONCLUSIONS}

The volume determinations for the non-mining-affected north slope Mount Moly debris fan, when assessed in context with water quality, bedrock alteration assemblage, and field-leach data, implicate the debris fan as a volumetrically large, acid producer and major- and trace-element loader to surface water. Water quality samples collected adjacent to mines located downstream from the non-mining-affected Red Tributary and the north slope Mount Moly debris fan may now be assessed with the knowledge that significant geochemical loading occurs upstream. Field-leach test comparisons between non-mining-affected surficial deposits derived from altered rocks and mine wastes provide an indication that both deposit types have the potential to generate acidity. GIS data synthesis for water and rock has aided in the identification of where non-miningaffected areas are affected by acid rock drainage. The Red Tributary is an example of a proportionately large source of acidic drainage that is unaffected by mining. Quantitative geochemical-loading determinations for the Red Tributary (Mast et al., this volume), along with GIS map displays and analysis aid in determining what the environmental effects of mineralized but unmined areas are for tributaries that flow into Mineral Creek from Mount Moly. These data may now be evaluated to predict what restoration goals are realistically achievable in the Middle Fork of Mineral Creek. 
Table 1 ICP-MS data for whole rocks and vein samples near Mount Moly. Analyical uncertainty for each element is approximately \pm 5 to $10 \%$. Al Meier analyst, U. S. Geological Survey (ppm, parts per million).

\begin{tabular}{|c|c|c|c|c|c|c|c|}
\hline Field Number & Description & Latitude & Longitude & $\begin{array}{c}\mathrm{Cu} \\
\mathrm{ppm}\end{array}$ & $\begin{array}{c}\mathrm{Zn} \\
p p m\end{array}$ & $\begin{array}{l}\text { Mo } \\
\text { ppm }\end{array}$ & $\begin{array}{c}P b \\
p p m\end{array}$ \\
\hline SDY-9701 & $\begin{array}{l}\text { Propylitically altered } \\
\text { monzonite porphyry, } \\
1 \text { vol \% pyrite. }\end{array}$ & $37^{\circ} 50^{\prime} 3^{\prime \prime}$ & $107^{\circ} 43^{\prime} 33^{\prime \prime}$ & 18 & 52 & 12 & 41 \\
\hline SDY-9705A & $\begin{array}{l}\text { Weak sericitically altered } \\
\text { monzonite porphyry, } \\
3 \text { vol \% pyrite. }\end{array}$ & $37^{\circ} 50^{\prime} 4^{\prime \prime}$ & $107^{\circ} 43^{\prime} 53^{\prime \prime}$ & 56 & 63 & 17 & 1,200 \\
\hline SDY-9705B & $\begin{array}{l}\text { Vein in monzonite } \\
\text { porphyry sample. }\end{array}$ & $37^{\circ} 50^{\prime} 4^{\prime \prime}$ & $107^{\circ} 43^{\prime} 53^{\prime \prime}$ & 1,200 & 72,000 & 1,700 & 37,000 \\
\hline SDY-9706 & $\begin{array}{l}\text { Propylitically altered } \\
\text { monzonite porphyry, } \\
1 \text { vol \% pyrite. }\end{array}$ & $37^{\circ} 49^{\prime} 59^{\prime \prime}$ & $107^{\circ} 43^{\prime} 58^{\prime \prime}$ & 35 & 48 & 16 & 50 \\
\hline SDY-9707 & $\begin{array}{l}\text { Q-S-P altered, } \\
\text { stockwork-veined } \\
\text { monzonite porphyry. }\end{array}$ & $37^{\circ} 49^{\prime} 57^{\prime \prime}$ & $107^{\circ} 49^{\prime} 57^{\prime \prime}$ & 34 & 53 & 15 & 49 \\
\hline SDY-9717 & $\begin{array}{l}\text { Stockwork-veined monzonite } \\
\text { porphyry, pyrite oxidized. }\end{array}$ & $37^{\circ} 49^{\prime} 46^{\prime \prime}$ & $107^{\circ} 44^{\prime} 44^{\prime \prime}$ & 7 & 20 & 4.5 & 46 \\
\hline SDY -9719 & $\begin{array}{l}\text { Weak sericitically altered lava, } \\
\text { pyrite oxidized. }\end{array}$ & $37^{\circ} 50^{\prime} 22^{\prime \prime}$ & $107^{\circ} 44^{\prime} 46^{\prime \prime}$ & 37 & 65 & 6.7 & 16 \\
\hline SDY-9718A & Q-S-P altered lava. & $37^{\circ} 50^{\prime} 6^{\prime \prime}$ & $107^{\circ} 44^{\prime} 34^{\prime \prime}$ & 15 & 45 & 2.2 & 190 \\
\hline SDY -9738 & $\begin{array}{l}\text { Weak sericitically } \\
\text { altered monzonite porphyry, } \\
3 \text { to } 5 \text { vol \% pyrite. }\end{array}$ & $37^{\circ} 49^{\prime} 16^{\prime \prime}$ & $107^{\circ} 44^{\prime} 9^{\prime \prime}$ & 140 & 20 & 8.6 & 17 \\
\hline SDY-9739 & $\begin{array}{l}\text { Q-S-P altered monzonite } \\
\text { porphyry, } 2 \text { vol \% pyrite. }\end{array}$ & $37^{\circ} 49^{\prime} 18^{\prime \prime}$ & $107^{\circ} 44^{\prime} 9^{\prime \prime}$ & 110 & 10 & 37 & 21 \\
\hline SDY -9740 & $\begin{array}{l}\text { Weak sericitically altered } \\
\text { monzonite porphyry. }\end{array}$ & $37^{\circ} 49^{\prime} 23^{\prime \prime}$ & $107^{\circ} 44^{\prime} 11^{\prime \prime}$ & 18 & 20 & 19 & 12 \\
\hline SDY-9741 & $\begin{array}{l}\text { Q-S-P altered monzonite } \\
\text { Porphyry. }\end{array}$ & $37^{\circ} 49^{\prime} 33^{\prime \prime}$ & $107^{\circ} 44^{\prime} 16^{\prime \prime}$ & 13 & 20 & 2.5 & 11 \\
\hline SDY-9742 & $\begin{array}{l}\text { Quartz-sericite-pyrophyllite } \\
\text { altered lava (?), pyrite oxidized. }\end{array}$ & $37^{\circ} 49^{\prime} 55^{\prime \prime}$ & $107^{\circ} 44^{\prime} 16^{\prime \prime}$ & 6 & 20 & 2.9 & 31 \\
\hline SDY-9743A & $\begin{array}{l}\text { Weak sericitically altered } \\
\text { monzonite porphyry, } \\
2 \text { vol \% pyrite. }\end{array}$ & $37^{\circ} 50^{\prime} 1^{\prime \prime}$ & $107^{\circ} 43^{\prime} 51^{\prime \prime}$ & 72 & 46 & 14 & 41 \\
\hline SDY-9743B & $\begin{array}{l}\text { Q-S-P altered vein, } \\
\text { pyrite oxidized. }\end{array}$ & $37^{\circ} 50^{\prime} 1^{\prime \prime}$ & $107^{\circ} 43^{\prime} 51^{\prime \prime}$ & 27 & 27 & 16 & 140 \\
\hline ODY -9731 & Propylitically altered lava. & $37^{\circ} 49^{\prime} 50^{\prime \prime}$ & $107^{\circ} 45^{\prime} 49^{\prime \prime}$ & 11 & 72 & 0.78 & 20 \\
\hline
\end{tabular}

Table 2 Mineralogy of north slope Mount Moly debris fan soil auger samples, determined by X-ray diffraction

\begin{tabular}{|c|c|c|c|c|}
\hline Sample & Description & Latitude & Longitude & Minerals Identified \\
\hline SDY9902D & $\begin{array}{l}\text { Debris fan toe, auger cuttings } 1-2 \\
\text { meter interval }\end{array}$ & $37^{\circ} 50^{\prime} 19^{\prime \prime}$ & $107^{\circ} 45^{\prime} 02^{\prime \prime}$ & $\begin{array}{l}\text { schwertmannite, quartz, } \\
\text { muscovite, clinochlore, } \\
\text { jarosite }\end{array}$ \\
\hline SDY9904B & $\begin{array}{l}\text { Upper debris fan surface } 1-2 \text { meter } \\
\text { interval }\end{array}$ & $37^{\circ} 50^{\prime} 16^{\prime \prime}$ & $107^{\circ} 45^{\prime} 01^{\prime \prime}$ & $\begin{array}{l}\text { schwertmannite, quartz, } \\
\text { goethite, muscovite, } \\
\text { clinochlore, jarosite }\end{array}$ \\
\hline SDY9906 & $\begin{array}{l}\text { Debris fan toe, auger cuttings } 0-2 \\
\text { meter composite }\end{array}$ & $37^{\circ} 49^{\prime} 13^{\prime \prime}$ & $107^{\circ} 45^{\prime} 06^{\prime \prime}$ & $\begin{array}{l}\text { schwertmannite, quartz, } \\
\text { muscovite, clinochlore, } \\
\text { jarosite }\end{array}$ \\
\hline
\end{tabular}


Table 3 Field-leach test results for non-mining-affected surficial deposits and mine wastes. Sample SDY9902D was leached by the passive-leach method described in Fey et al. (this volume). Most samples were collected near Mount Moly with the exception of those from the debris fan located east of Highway 550 near Silverton. Philip Hageman and Michael Anthony of the U.S. Geological Survey completed field-leach test experiments. Samples were filtered using a $0.45 \mu \mathrm{m}$ filter and acidified for later metals analyses.

\begin{tabular}{|c|c|c|c|c|}
\hline Sample & Description & Location & $\begin{array}{c}\text { PH of filtered }(0.45 \\
\mu m) \text { leachate }\end{array}$ & $\begin{array}{c}\text { Specific conductance } \\
\mu S / c m \text { of filtered }(0.45 \\
\mu m) \text { leachate }\end{array}$ \\
\hline $\begin{array}{l}\text { SURFICIAL } \\
\text { DEPOSITS }\end{array}$ & & & & \\
\hline SDY9908 & $\begin{array}{l}\text { North slope Mt. } \\
\text { Moly debris fan, } \\
\text { south of Red } \\
\text { Tributary. }\end{array}$ & $\begin{array}{l}37^{\circ} 50^{\prime} 2^{\prime \prime} \\
107^{\circ} 44^{\prime} 49^{\prime \prime}\end{array}$ & 4.45 & 16 \\
\hline SDY9902D & $\begin{array}{l}\text { North slope Mt. } \\
\text { Moly debris fan } \\
\text { auger cuttings, } \\
\text { south of Red } \\
\text { Tributary. }\end{array}$ & $\begin{array}{l}37^{\circ} 50^{\prime} 19^{\prime \prime} \\
107^{\circ} 45^{\prime} 02^{\prime \prime}\end{array}$ & 4.10 & N.A. \\
\hline SESFAN & $\begin{array}{l}\text { Debris fan south } \\
\text { side } \\
\text { Mt. Moly. }\end{array}$ & $\begin{array}{l}37^{\circ} 49^{\prime} 13^{\prime \prime} \\
107^{\circ} 44^{\prime} 11^{\prime \prime}\end{array}$ & 4.16 & 22 \\
\hline SDY9913 & $\begin{array}{l}\text { Colluvium deposit } \\
\text { north of Red } \\
\text { Tributary. }\end{array}$ & $\begin{array}{l}37^{\circ} 50^{\prime} 26^{\prime \prime} \\
107^{\circ} 44^{\prime} 59^{\prime \prime}\end{array}$ & 5.68 & 5 \\
\hline SDY9917 & $\begin{array}{l}\text { Debris Fan, east of } \\
\text { Highway } 550 .\end{array}$ & $\begin{array}{l}37^{\circ} 49^{\prime} 2^{\prime \prime} \\
107^{\circ} 41^{\prime} 55^{\prime \prime}\end{array}$ & 3.92 & 54 \\
\hline $\begin{array}{l}\text { MUNE WASTES } \\
\text { Ruby Trust Mine }\end{array}$ & $\begin{array}{l}\text { N. of Middle Fork } \\
\text { of Mineral Creek. }\end{array}$ & $\begin{array}{l}37^{\circ} 50^{\prime} 45^{\prime \prime} \\
107^{\circ} 45^{\prime} 7^{\prime \prime}\end{array}$ & 3.73 & 105 \\
\hline $\begin{array}{l}\text { Paradise Portal } \\
\text { Mine }\end{array}$ & $\begin{array}{l}\text { Base of Paradise } \\
\text { basin. }\end{array}$ & $\begin{array}{l}37^{\circ} 50^{\prime} 32^{\prime \prime} \\
107^{\circ} 45^{\prime} 52^{\prime \prime}\end{array}$ & 3.87 & 1,594 \\
\hline Bonner Mine & $\begin{array}{l}\text { E. of Red } \\
\text { Tributary. }\end{array}$ & $\begin{array}{l}37^{\circ} 50^{\prime} 36^{\prime \prime} \\
107^{\circ} 44^{\prime} 13^{\prime \prime}\end{array}$ & 3.89 & 63 \\
\hline
\end{tabular}

The approach used in this study to: (1) develop a GIS database, (2) synthesize and evaluate water quality, geology and alteration data, in a spatial context, and (3) focus on local geochemical anomalies in the field demonstrates the benefits of using GS to integrate and interpret geographic, geologic, and geochemical data.

\section{ACKNOWLEDGMENTS}

We thank Alison Burchell (University of Colorado, Boulder) for helpful discussions and review of this work. In addition we thank Laurie Wirt and Rick Sanzolone (U.S. Geological Survey) for their reviews. ICARD reviewers provided helpful suggestions, which improved this manuscript. Robert T. McCusker provided useful information regarding AMAX Exploration, Inc., work on the Mount Moly prospect. We also thank Professor Rob Blair (Fort Lewis College, Durango, Colorado) and his 1999 Southwestern Earth Studies, National Science Foundation-sponsored class for their participation in the field-leach studies. 


\section{REFERENCES}

Bailey, R. G., 1995. Description of the ecoregions of the United States. United States Department of Agriculture Miscellaneous Publication 1391.

Bigham, J. M., Schwertmann, U., Traina, S. J., Winland, R. L., and Wolf, M., 1996. Schwertmannite and the chemical modeling of iron in acid sulfate waters. Geochimica et Cosmochimica Acta, Vol. 60, No. 12, p. 2111-2121.

Bigham, J. M., Carlson, L., and Murad, E., 1994. Schwertmannite, a new iron oxyhydroxy-sulfate from Pyhäsalmi, Finland, and other localities. Mineralogical Magazine, Vol. 58, p. 641-648.

Bove, D. J., Hon, K., Budding, K., Slack, J. F, Snee, L. W., and Yeoman, R. A, 1999. Geochronology and geology of late Oligocene through Miocene volcanism and mineralization in the western San Juan Mountains, Colorado. U.S. Geological Survey Open-File Report 99-347, 35 p.

Burbank, Wilbur S., Luedke, Robert G., 1969. Geology and ore deposits of the Eureka and adjoining districts, San Juan Mountains, Colorado. U. S. Geological Survey Professional Paper 535, p. 73.

Casadevall, T. C., and Ohmoto, H., 1977. Sunnyside mine, Eureka mining district, San Juan County, Colorado. Geochemistry of gold and base metal ore deposition in a volcanic environment. Economic Geology, Vol. 72, p. 1285-1320.

Colorado Department of Health, 1984. Basic standards and methodologies, 3.1.0 (5 CCR 1002-8), p. 36.

Desborough, G., Briggs, P., Mazza, N., and Driscoll, R, 1998. Acid-neutralizing potential of minerals in intrusive rocks of the Boulder Batholith in northern Jefferson County, Montana. U.S. Geological Survey Open-File Report 98-364, 21 p.

Fortescue, J. A. C., 1992. Landscape geochemistry: retrospect and prospect-1990. Applied Geochemistry, Vol. 7, No. 1, p. 1-53.

Guilbert, J. M., and Lowell, J. D., 1974. Variations in zoning patterns in porphyry ore deposits. Canadian Mining and Metallungical Bulletin, Vol. 67, No. 742, p. 99-109.

Henley, R. W., and McNabb, A., 1977. Magmatic vapor plumes and ground-water interaction in porphyry copper emplacement. Economic Geology, Vol. 73, No. 1, p. 1-20.

Herron, J., Stover, B., and Krabacher, P., 1998. Cement Creek reclamation feasibility report, upper Animas = River Basin. Colorado Division of Mines and Geology, Clift, A., ed., 139 p.

Lamplugh, G. W., 1902. Calcrete: Geological Magazine, Dec. 4, Vol. 9., No. 462, p. 575.

Lipman, P. W., Fisher, F. S., Mehnert, H. H., Naeser, C. W., Luedke, R. G., and Steven, T. A., 1976. Multiple ages of mid-Tertiary mineralization and alteration in the western San Juan Mountains, Colorado. Economic Geology, Vol. 71, p. 571-588.

Lipman, P.W., Steven, T. A., Luedke, R. G., and Burbank, W. S., 1973. Revised volcanic history of the San Juan, Uncompahgre, Silverton and Lake City calderas in the western San Juan Mountains, Colorado. U. S. Geological Survey Journal of Research, Vol. 1, No. 6, p. 672-642.

Lipman, P. W., Prostka, H. J., Christiansen, R. L., 1972, Cenozoic volcanism and plate-tectonic evolution of the western United States; I, Early and middle Cenozoic. Philosophical Transactions of the Royal Society of London, Series A: Mathematical and Physical Sciences, Vol. 271, p. 217-248.

Luedke, R. G., and Burbank, W. S., 1996. Geologic map of the Ophir Quadrangle, San Juan, Hinsdale, and Ouray Counties, Colorado. U.S. Geological Survey Quadrangle Map GQ-152.

Luedke, R. G, and Burbank, W. S., 1987. Geologic map of the Handies Peak Quadrangle, San Juan, Hinsdale, and Ouray Counties. U.S. Geological Survey GQ-1595.

Luedke, R. G, and Burbank, W. S., 1963. Tertiary volcanic stratigraphy in the western San Juan Mountains, Colorado. Short Papers in Geology and Hydrology, U.S. Geological Survey Professional Paper 475-C, p. C39-C44

Miller, W. R. 1998. Geochemical baselines and processes affecting surface water, Redcloud Peak area, Colorado. U.S. Geological Survey Open-File Report 98-35.

Munsell Soil Color Charts: GretagMacBeth, 617 Little Britain Road, New Windsor, NY, 12553.

Nordstrom, D. K., Alpers, C. N., Coston, J. A., Taylor, H. E., McCleskey, R. B., Ball, J. W., Ogle, S., and Davis, J. A., 1999. U.S. Geological Survey Toxic Substances Hydrology Program, Proceedings of the Technical Meeting, Charleston, S. C., March 8-12, 1999, p. 289-296.

Ringrose, C. R., 1982. Geology, geochemistry, and stable isotope studies of a porphyry-style hydrothermal system, west Silverton district, San Juan Mountains, Colorado. Ph.D. dissertation, University of Aberdeen, $257 \mathrm{p}$.

Schwertmann, U., Bigham, J. M., and Murad, E., 1995. The first occurrence of schwertmannite in a natural stream environment. European Joumal of Mineralogy, Vol. 7, p. 547-552. 
Steven, T. A., 1996. Geomorphic evolution and history of pollution in the vicinity of the Summitville district, San Juan Mountains, Colorado. Geological Society of America Field Guide, Hydrology of the San Luis Valley and Environmental Issues downstream from the Summitville Mine.

Steven, T. A., Lipman, P. W., Hail, W. J. Jr., Barker, F., Luedke, R. G., 1974. Geologic Map of the Durango Quadrangle, Southwestern Colorado. U. S. Geological Survey Miscellaneous Investigation Series I-764.

USEPA, 1988. Ambient water-quality criteria for aluminum. Environmental Protection Agency, U.S. EPA 440/5-88-008.

Varnes, David J., 1963. Geology and ore deposits of the South Silverton mining area, San Juan County, Colorado. U.S. Geological Survey Professional Paper 0378-A, p. A1-A56.

Yager, D. B., 1999. Alteration zones, mines and prospects, and dissolved copper concentrations overlain on a topographic base for the Mount Moly region, Silverton, Colorado. Environmental Systems Research Institute, Inc., ESRI Map Book, Vol. 14, p. 38. 


\title{
Multidimensional Spatial Modeling of the May Day Mine Waste Pile, Silverton, Colorado
}

\author{
Douglas B. Yager and Mark R. Stanton ${ }^{1}$
}

\begin{abstract}
Integration and synthesis of mine-site topography, geophysical, and geochemical data yields both twodimensional and three-dimensional perspective models for the May Day mine located in the Cement Creek drainage near Silverton, Colorado. Induced polarization, geophysical data are spatially registered with geochemical data acquired from drill hole cuttings that are contoured in three-dimensional space, thereby permitting determination of the most metalliferous and sulfur rich zones of a waste pile. This spatial modeling application was developed to be a visually intuitive tool to aid in mine waste reclamation.
\end{abstract}

\section{INTRODUCTION}

There are currently about 47,000 past producing hard rock mines located mainly in the western U.S. (Ferderer, 1996) that potentially impact local water quality and that are possible candidates for abandoned mine lands reclamation by state and federal agencies. Mine waste characterization is an important aspect of this complex task and a simple, visually intuitive mine waste model is, in turn, an integral part of the mine waste characterization process. Two and three-dimensional modeling of mine wastes provides visual information that scientists and land managers can use to assess the economic and environmental pros and cons of either: (1) remediating a mine site, (2) leaving a site undisturbed, or (3) re-mining a site for unprocessed ore. Eventually, spatial models that integrate all available data for the most problematic sites will be used to evaluate the cumulative impact for an entire watershed.

The May Day waste pile was selected for spatial modeling in this study because: (1) the field leach test (Hageman and Briggs, this volume) was used to identify the waste pile as a potential acid and metals producer, (2) the drill core data is available, and (3) the Bureau of Land Management has targeted the May Day mine for remediation. The geochemical information acquired from mine wastes in abandoned mine lands studies is predominately from samples collected near the first few centimeters of a waste pile surface. Available drill hole data for the May Day waste pile made it possible to geochemically analyze the core and "view" the geochemical characteristics inside the pile to depths of approximately 5 meters.

\section{GEOLOGIC SETTING AND MINERALOGY OF THE MAY DAY MINE}

The study area is located in the southwestern part of the San Juan Volcanic Field, where Tertiary volcanics blanket Paleozoic and Mesozoic sedimentary rocks and a Precambrian crystalline basement (Steven, et al., 1974). The May Day Mine is located north of Silverton, Colorado, in the Cement Creek drainage near Topeka Gulch (Fig. 1). The mine is hosted in Silverton Volcanic Series (SVS) lavas. The SVS lavas have been regionally propylitically altered by hydrothermal activity that is associated with Tertiary, volcanotectonic and caldera forming events (Burbank and Luedke, 1969). Quartz, incipiently altered feldspars, chlorite, epidote, opaque oxides, \pm calcite, and \pm pyrite comprise the propylitic assemblage. The mine was apparently, only an exploratory prospect. The May Day mine tunnel appears (based on field mapping by the authors) to have been constructed to access weakly mineralized, northeast-southwest trending veins (Fig. 2). $\mathrm{X}$-ray diffraction analysis of surface samples detected the presence of quartz ( $>5$ weight percent) with minor amounts ( $\leq 5$ weight percent) of muscovite, jarosite, orthoclase, sphalerite, clinochlore, and pyrophyllite (Sutley, 1999, U.S. Geological Survey, unpublished data).

\footnotetext{
${ }^{1}$ Both at U.S. Geological Survey, Denver, Colorado
} 


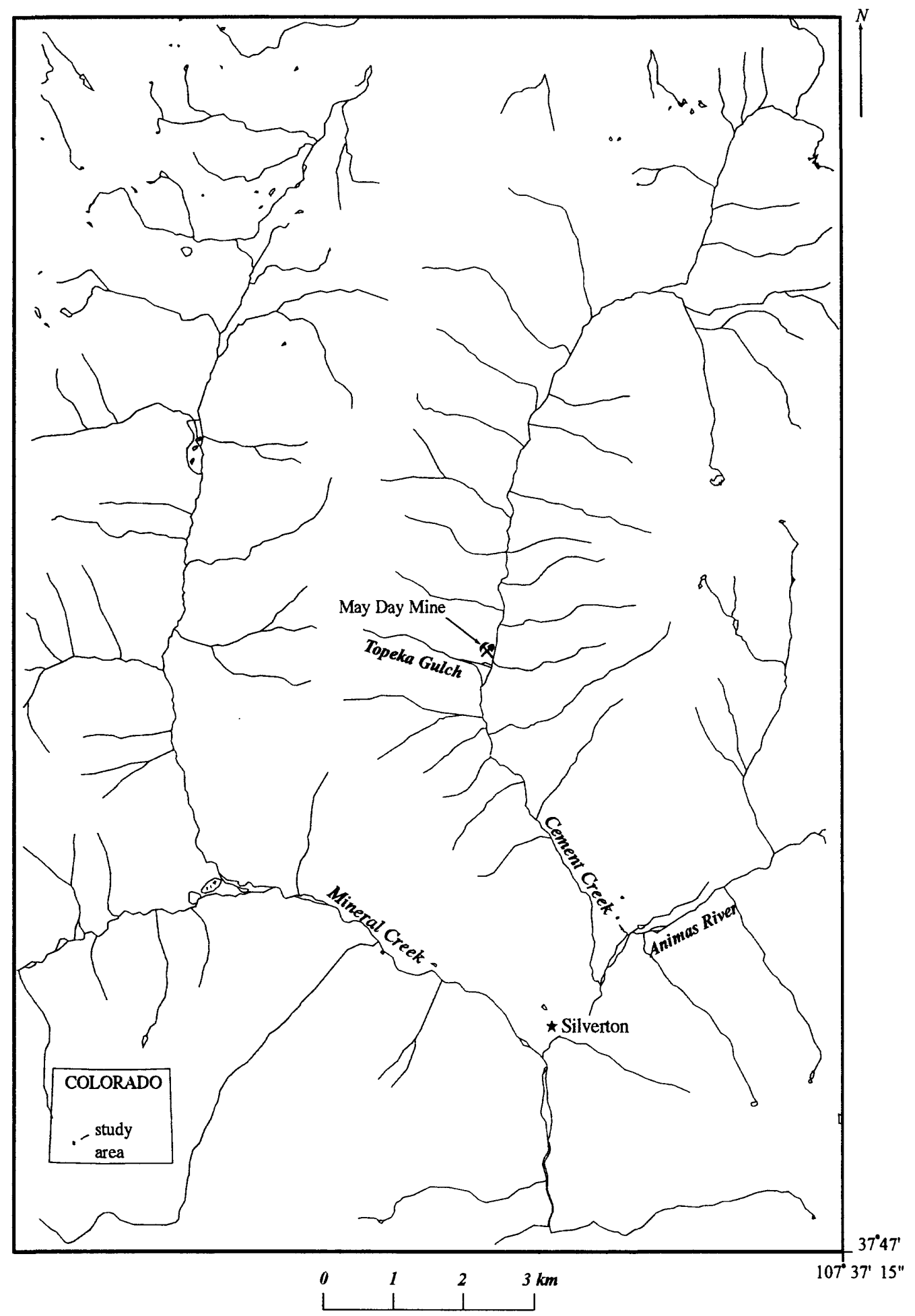

Figure 1 Drainage network for part of the upper Animas River watershed and location of the May Day mine (pick and shovel symbol) and town of Silverton (star symbol). 


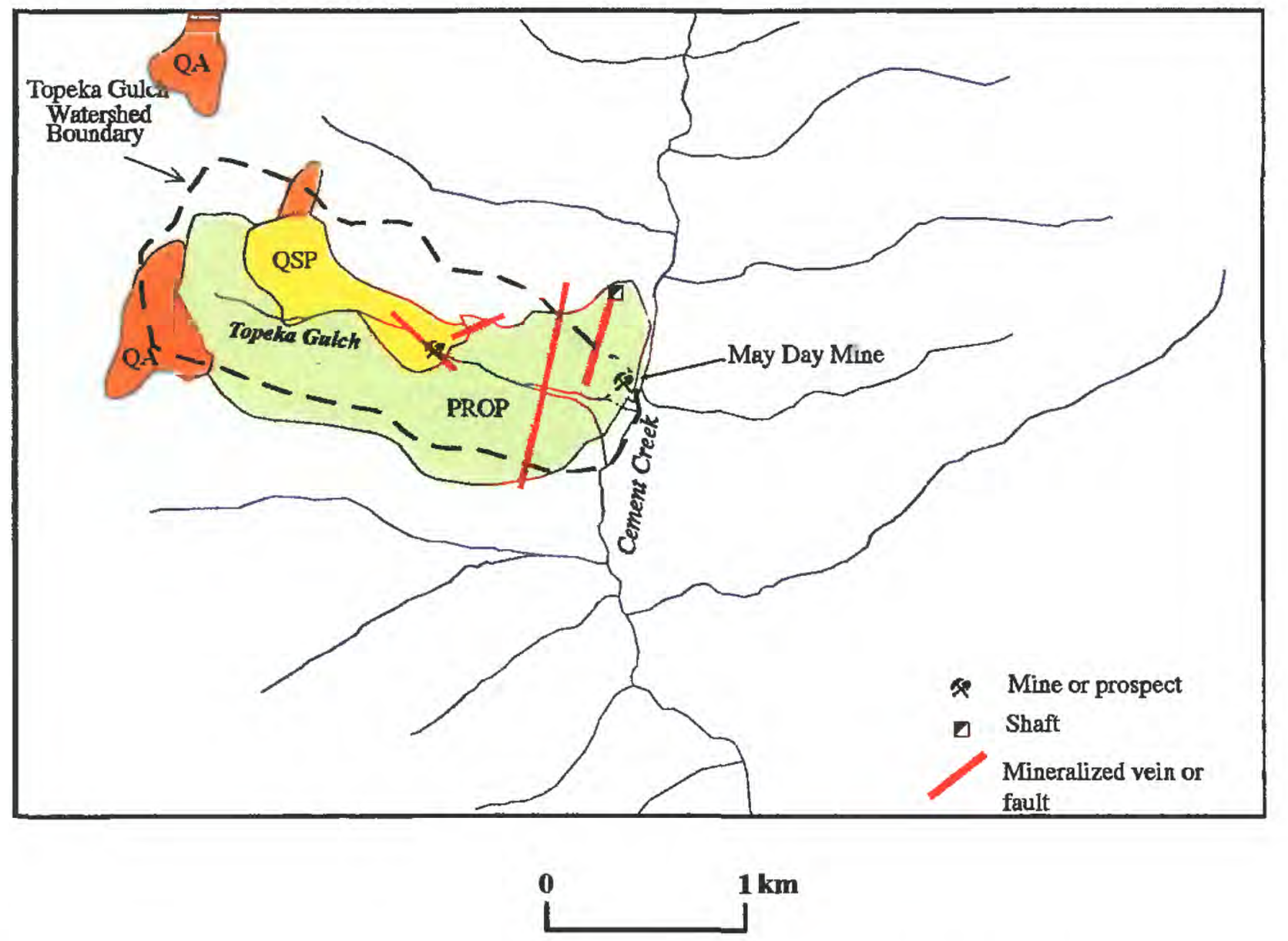

Figure 2 Generalized alteration map (by the authors) for the Topeka Gulch sub-watershed. Alteration assemblages include: (1) PROP (propylitic) chlorite, epidote, +/- calcite, +/- pyrite, opaque oxides, (2) Q-S-P quartz-sericite-pyrite, and (3) QA quartz, alunite.

X-ray diffraction analysis of drill hole cuttings from a sample with high metal concentrations from the northern part of the pile detected the presence of major amounts of sphalerite, and minor to trace amounts of plumbojarosite, quartz, gypsum, galena, muscovite, anglesite, and sericite (Stanton and Campbell, this volume). X-Ray diffraction of heavy mineral concentrates detected the presence of pyrite, galena coated with anglesite, ferberite and barite (Desborough, et al., 1999).

\section{TWO-AND THREE-DIMENSIONAL MODELING}

\section{Methods}

The mine waste pile is constructed as a series of three benches, which provide a stable platform for drill-core sampling. Six holes were drilled and continuous core sampled through the May Day waste pile in the summer of 1997. Four holes were drilled in the upper bench, and one hole in each of the middle and lower benches. Drill core splits were collected at one-foot intervals and analyzed by 40 -element inductively coupled plasma (ICP) at XRAL laboratories, Canada.

Compaction corrected, drill hole geochemical data coordinates and corresponding $x-y-$ and $z-$ topographic surface coordinates (Hein and Fitterman, 1998) were integrated in the spatial modeling software Earth Vision ${ }^{2}$, to construct a three-dimensional grid for the mine-site surface and subsurface (Figure 3). These geochemical grids, or contour models, are generated using a minimum tension gridding algorithm. A top-conformal gridding routine was used to map the three-dimensional block of geochemical data to the actual three-dimensional topographic profile of the waste pile. The top-conformal gridding successfully mimicked the bench and slope aspect of the waste pile surface. Ideally, a bottom-conformal grid is used to force gridding to occur above a lower bounding surface, such as bedrock. However, a bottom-conformal routine could not be used because only one drill hole pierced through the entire waste pile and the bedrock morphology could not be constrained. Three-dimensional grids in Earth Vision were rotated to view multiple perspectives.

${ }^{2}$ Any use of trade names, product, or firm names is for descriptive purposes only and does not imply endorsement by the U.S. Geological Survey. 
IP geophysical profile

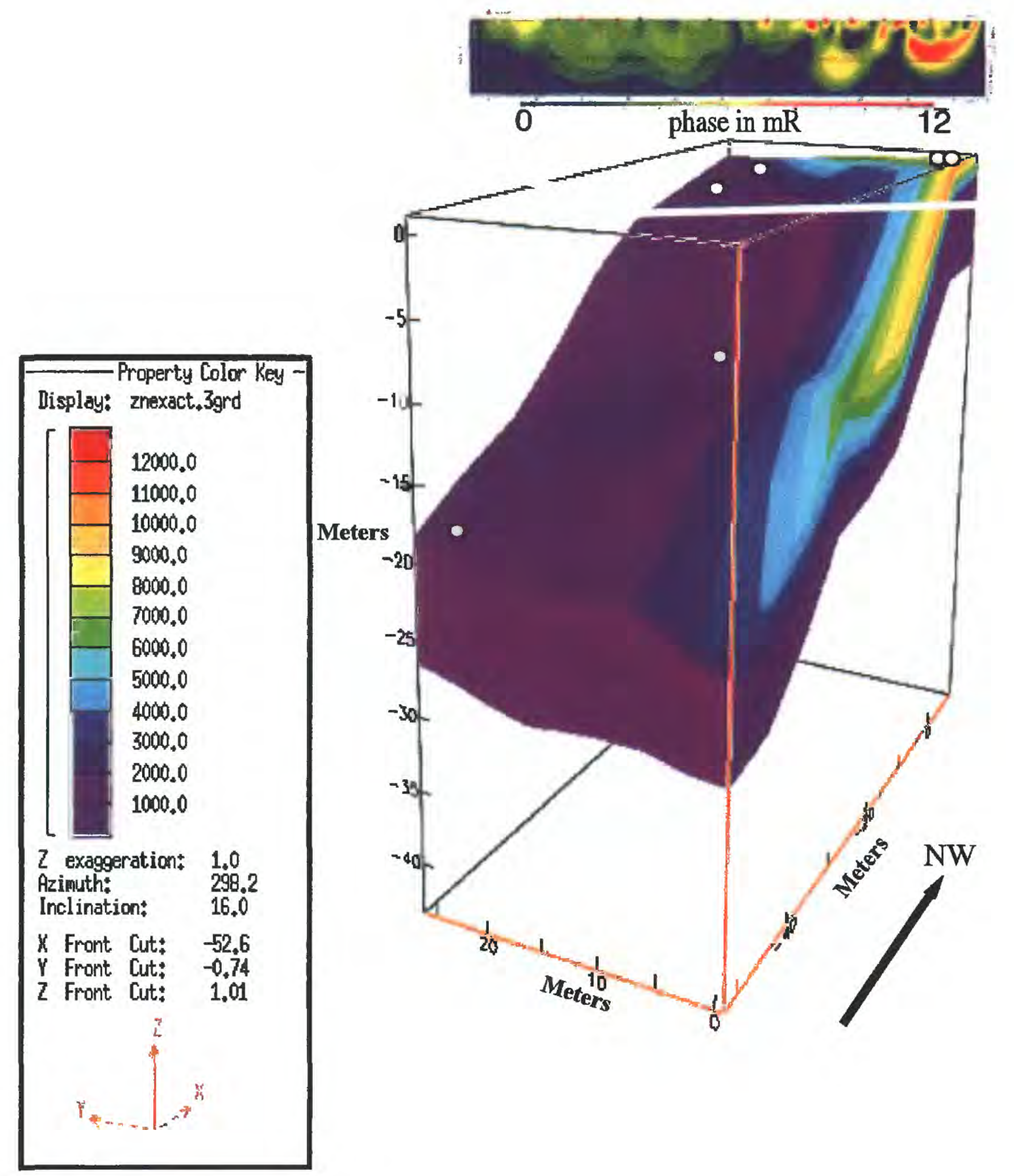

Figure 3 Synthesis of 2-dimensional topographic data, three-dimensional, geochemical gridded data for $\mathrm{Zn}$ (ppm) and geophysical induced polarization profile for the May Day mine. Note that high concentrations of zinc in the upper right (northern) part of the pile coincide with a relatively high IP (10 milliradian) signal (red area on right side of upper image, color version in back of this volume). Zinc alone is not responsible for the relatively high IP signal in the northern part of the pile. Therefore, other sulfide minerals such as minor to trace amounts of pyrite and galena may be responsible for the relatively higher IP signal. White line across the face of the upper bench indicates the approximate IP profile location. Drill hole locations indicated by open circles. 
The various views were sliced to produce three-dimensional cross section models of the geochemical grids and to test for correspondence between model values and drill-hole geochemical values. Finally, the threedimensional geochemical models were co-registered with 2-dimensional profiles of geophysical induced polarization (IP) data using desktop image analysis software. IP is used to measure the rates at which electrical charges build up in the ground when a voltage is applied (Campbell and Fitterman, this volume). This technique measures apparent resistivity and is successfully used to identify disseminated sulfides (Dobrin, 1976). In addition, IP provides information about the chargeability at the mineral pore-water interface, with sulfides causing a higher charge than non-sulfide minerals. The geochemical and mineralogical composition of the interior of the pile was evaluated to aid in the interpretation of IP geophysical signatures acquired (Campbell and Fitterman, this volume).

\section{Results}

The geochemical modeling routine successfully identified high concentrations of zinc (two weight percent) and sulfur (nine weight percent) near the northern part of the pile. This result is consistent with the presence of major amounts of sphalerite and minor amounts of plumbojarosite, gypsum, galena, and anglesite identified by X-ray diffraction in this part of the pile. In addition, elevated concentrations of lead $(30,000$ ppm), copper (4,600 ppm), and arsenic (670 ppm) were found to occur in the northern part of the pile. In contrast, geochemical contour grids show lower concentrations of metals and sulfur on the middle and lower benches. This is consistent with the predominance of weakly mineralized waste rock and propylitized volcanic host rock at the base of the pile.

Registration of the three-dimensional geochemical models with two-dimensional profiles of geophysical induced polarization data shows that the relatively higher IP signals (10 milliradians) for the northern part of the waste pile are consistent with the presence of sulfides other than sphalerite (Campbell and Fitterman, this volume). Therefore, the galena or minor amounts of pyrite, observed in heavy mineral concentrates, may be effecting the IP response.

\section{CONCLUSIONS}

Geophysical responses of rocks at a particular location at depth within a waste pile are inferred but not directly measured by such methods as induced polarization (Campbell and Fitterman, this volume). Drill core data and geochemical sampling are used to enhance the information at a known point. The geochemical gridding, or contour modeling, minimum-tension gridding algorithin used in this study successfully combined all available information to interpolate between sample locations. Integration of three-dimensional waste pile surface data with three-dimensional contour models generated from geochemical concentration data creates a realistic picture that enables the visualization of the spatial relationships of metal or sulfur concentrations (Figure 3). A greater understanding of acid mine drainage will be gleaned as we continue to develop and implement strategies that use three-dimensional modeling and geographical information systems to view and interpret data to aid in characterizing a mine-waste site.

\section{ACKNOWLEDGEMENTS}

The authors thank Briant Kimball, David Naftz, Gregory Green, and Robert McDougal for reviewing this manuscript. Zeke Zanoni provided useful information regarding the early history of the May Day mine.

\section{REFERENCES}

Burbank, W. S., and Luedke, R. G, and 1969. Geology and ore deposits of the Eureka and adjoining districts San Juan San Juan Mountains, Colorado. U.S. Geological Survey Professional Paper 535, 73 p.

Desborough, G. Leinz, R., Smith, K., Hageman, P., Fey, D., and Nash, T., 1999. Acid generation and metal mobility of some metal-mining related wastes in Colorado. U.S. Geological Survey Open-File Report, 99-322, 18 p.

Dobrin, M. B., 1976. Introduction to geophysical prospecting. McGraw-Hill, Inc., p. 608-661.

Ferderer, D. A., 1996. National overview of abandoned mine land sites utilizing the minerals availability system (MAS) and geographic information system (GIS) technology. U.S. Geological Survey, OpenFile Report 96-549.

Hein, A. S., and Fitterman, D. V., 1998. Topographic surveys of selected mine dumps near Silverton, and Leadville, Colorado. U. S. Geological Survey Open-File Report, 98-588.

Steven, T. A., Lipman, P. W., Hail, W. J. Jr., Barker, F., Luedke, R. G., 1974. Geologic Map of the Durango Quadrangle, Southwestern Colorado. U.S. Geological Survey Miscellaneous Investigation Series, I-764. 